\title{
Phenomenology of the Eucharist: \\ A Reflection on Traditioning
}

\section{Kevin James Connors}

A thesis submitted to the Victoria University of Wellington in fulfilment of the requirements for the degree of Doctor of Philosophy

Victoria University of Wellington

2018 



\section{Contents}

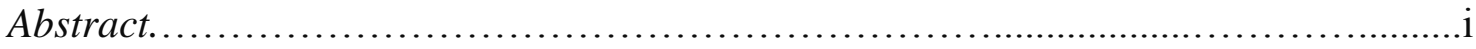

Acknowledgements..............................................................................................ii

Introduction ..................................................................

Part A: The Ultimate and the Emergent Issue: Identity and

Relationship - as it Arises through the Eucharist........................... 3

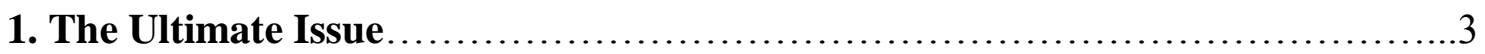

(a) Pannikar and Heidegger: An Initial Approach to the Ultimate Issue ...............3

(b) Levinas and the Relational Revolution: A Developing Approach to the Ultimate Issue.................................................................5

(c) Approaching the Issue through Relational Reflection - Mind, Mouth, Voice and Ear................................................................. 8

(i) The Relational Genesis of Language..................................... 8

(ii) A Brief Analysis..................................................8

(d) Applying the Above Distinctions in this Thesis.................................................10

(e) The Difficult Revolution................................................. 11

(f) Levinas and Thomas Aquinas.............................................. 12

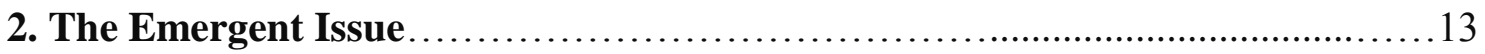

(a) Phenomenology and the Eucharist......................................... 14

(i) The Contribution of Phenomenology to Christianity and the Eucharist .........14

(ii) The Significance for Christianity ..................................... 16

(iii) The Significance of Studying the Eucharist for Phenomenology............17

\section{Part B: The Areas of Research and the Methodology for this}

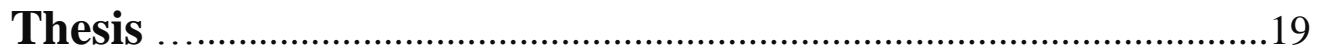

1. The Areas of Research.................................................. 19

(a) The Three Disciplines through which this Thesis is being Developed; History, Philosophy and Spirituality (the spirituality of discipleship).

(i) The Emergence of Distinction between Identity and Relationship in the History of the Eucharist...................................................20

(ii) The Philosophical Emergence of the Issue................................21

(iii) The Spiritual Emergence of the Issue...................................22

(b) How do Traditional Signs Signify? An Unresolved Problem in all Fields

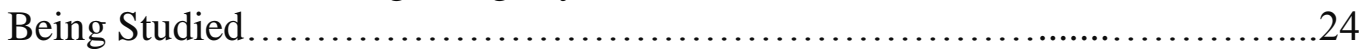

(i) The loss of relationship in the History of the Eucharist.......................24

(ii) The loss of relationship in the Literature of Phenomenology................24

(iii) The loss of relationship in the Spirituality of the Eucharistic Disciple........25

(iv) The Eucharist and the Sense of Tradition.............................26 


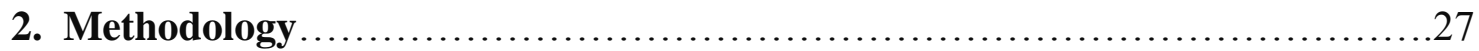

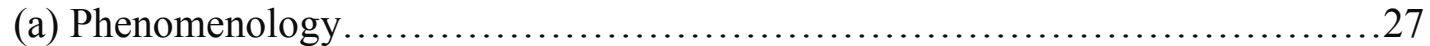

(b) Reflective Approaches to Scripture and other Traditional Documents.............29

(c) The Relationship to Other Phenomenologies of the Eucharist.........................31

(d) Further Reflections on the Methodology of This Thesis...........................36

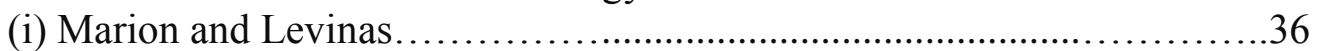

(ii) Levinas and the Methodology of This Thesis......................................39

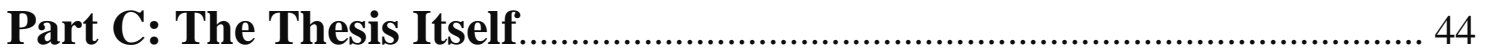

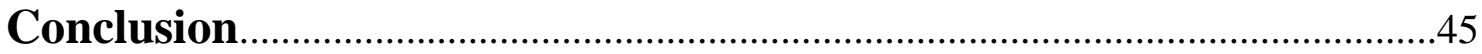

\section{Chapter One: The Primitive Eucharist and the Apocalyptic}

Sign ...........................................................................47

Introduction: “The Last Supper Is The Supper That Lasts”...................47

1. The Meanings of "Sign" and "Traditional Sign"...............................................47

2. Of Passivity and Agency .............................................................................50

3. Passivity and Agency in the Traditioning of the Eucharist................................51

Part A: Contemporary Eucharist and its Historical Foundations...........53

1. The Ancient and Contemporary Eucharist.......................................................53

(a) A Canonically Authorised Eucharist in Wellington............................................... 53

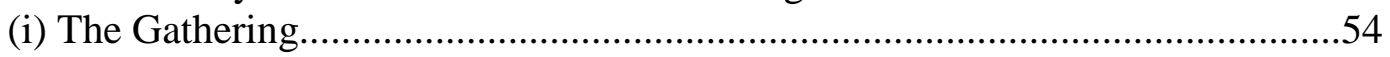

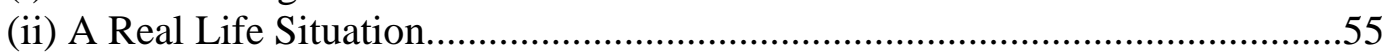

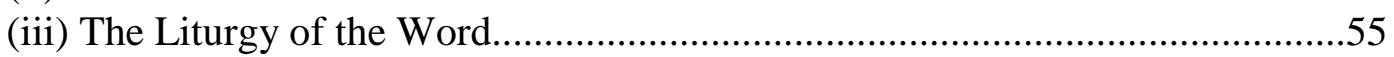

(iv) The Liturgy of the Eucharist..........................................................................5

(v) The Communion Rite...................................................................................58

(vi) The Formal and Informal Processes of Departure...........................................59

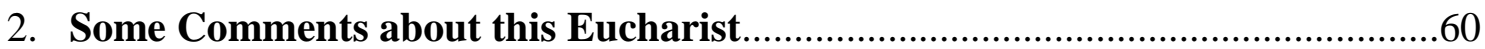

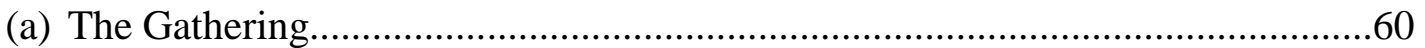

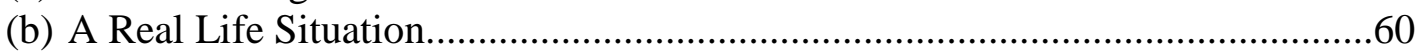

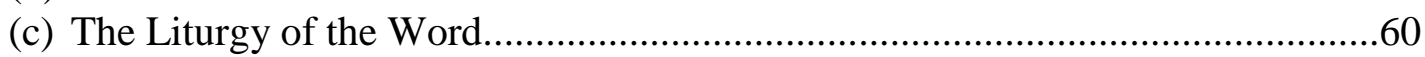

(d) The Liturgy of the Eucharist - from Word to Sacrifice........................................61

(i) The Agreement to Offer Sacrifice..................................................................62

(ii) From Baptism to Eucharist through the Revelation of God's Beloved Son.. 64

(iii) The Eucharistic Prayer..................................................................................66

(e)The Communion Rite, and the Symbolism of the "Lamb of God".......................68

3. Particular and universal characteristics of the celebration..................................68

(a) Particular Characteristics.............................................................................69

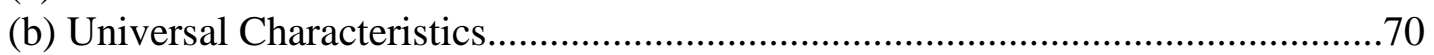

Part B: Historical and Apocalyptic Treatment of the Eucharist.............72

1. A Reflection on the Origins of the Eucharist.....................................................72

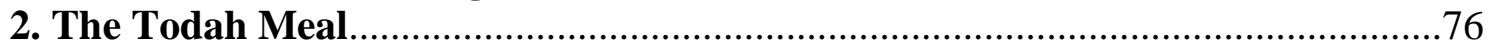

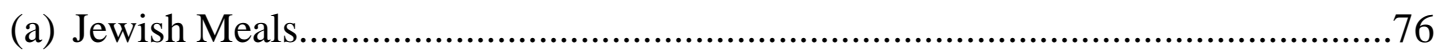




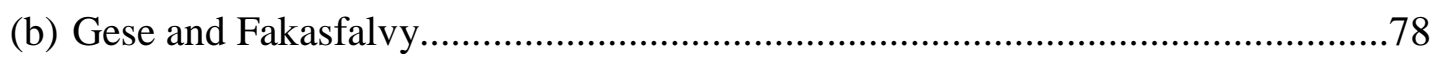

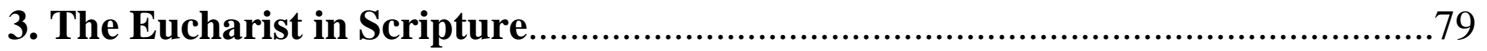

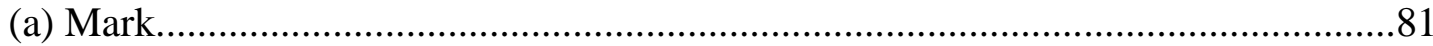

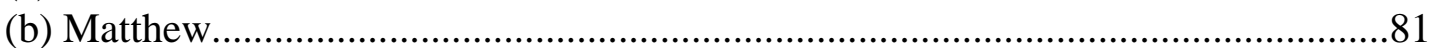

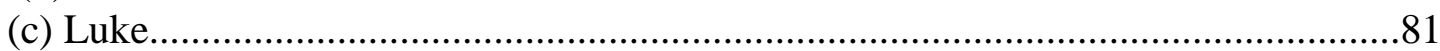

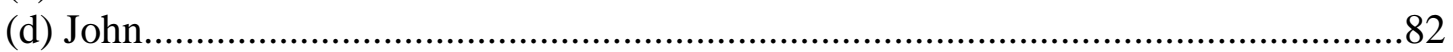

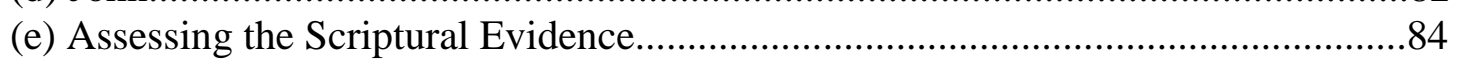

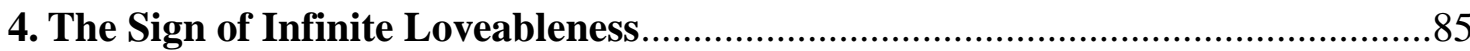

\section{Chapter Two: Approaching the Eucharists of the Metaphys- ical Traditions.}

Introduction.

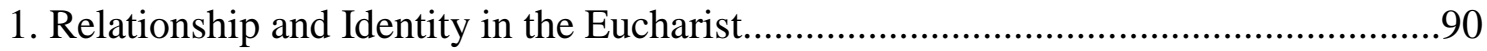

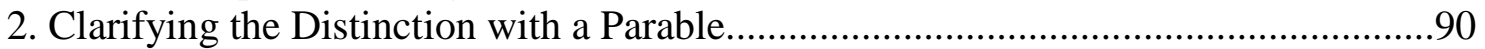

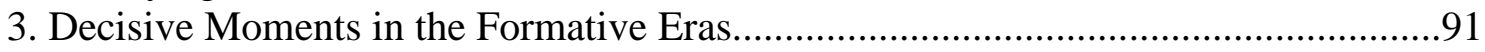

4. The Profound and Enduring Influence of these Texts...........................................92

Part A: Eucharistic Traditioning in John's Gospel..................................94

1. The Eucharist at the Beginning of the Post-apostolic Era...................................95

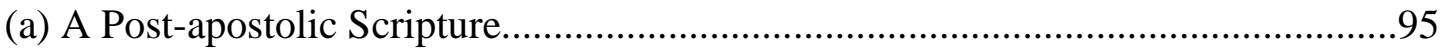

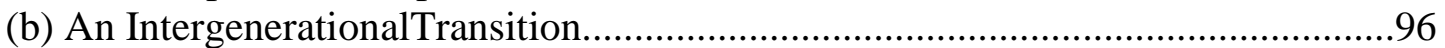

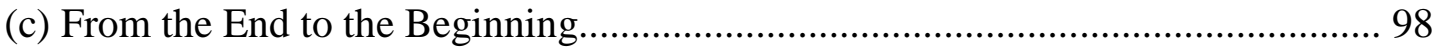

2. The Journey into the Johannine Eucharist......................................................98

(a)The Post-apostolic Era and the deeper Meanings of the Gospel..........................98

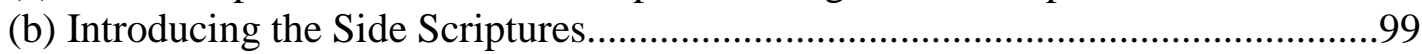

(c) The Significance of the 3 "Side" Words and the 5 "Side" Texts..........................101

(i) "кó $\lambda \pi 0 \varsigma$ "/ "Bosom/Lap/ Womb".............................................................101

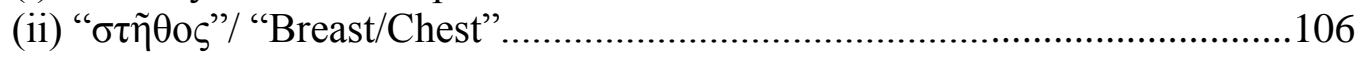

(iii) " $\pi \lambda \varepsilon v \rho \alpha ́$ " literally "rib" by extension "side"...........................................109

(d) Traditioning and the Transformation of Betrayal..............................................110

(i) The Eucharist and the Difference between Good and Evil.......................113

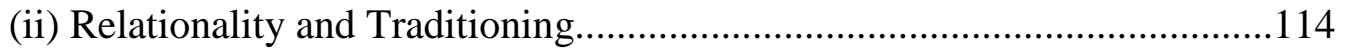

(iii) Hospitality, Spirituality and Agency..............................................115

3. Peter and John: Some Basic Traditional Paradigms.........................................117

(a) The Beloved Disciple Finds His Dwelling Place..............................................119

(b) Peter and the Eucharist of the Relational Agent...............................................120

\section{Part B: Looking Forward from the Biblical Era: The Next Two} Centuries...

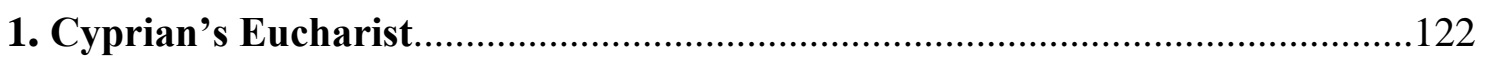

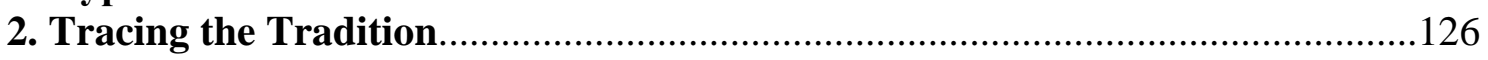




\section{Chapter 3: How the Eucharist Temporalizes: A}

\section{Phenomenological Description of the Eucharist....137}

Introduction

Part A: Basic Concepts in the Traditioning of the Eucharist................139

1. Low-christology and the Origins of the Eucharist............................................139

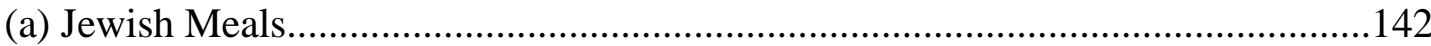

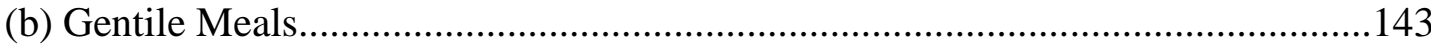

(c) The Formation and Significance of the Last Supper Tradition.............................145

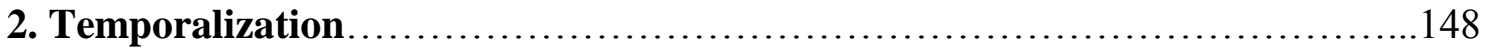

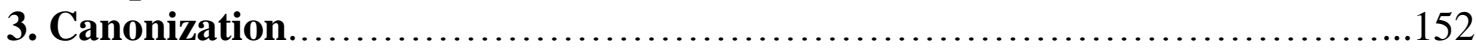

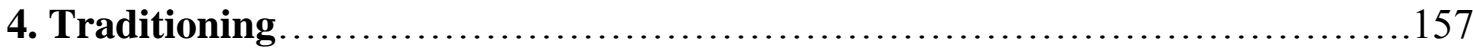

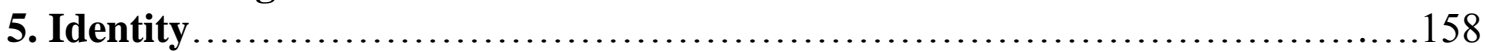

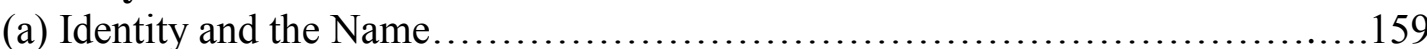

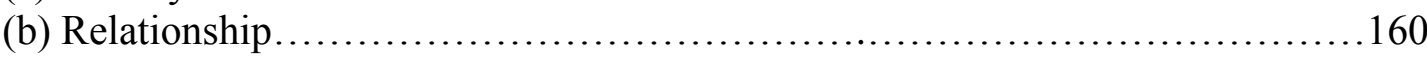

Part B: How the Eucharist has Temporalized through History...........162

1. The Earliest Kinds of Literature Referring to the Eucharist..............................162

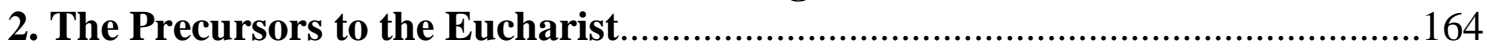

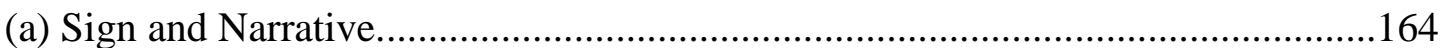

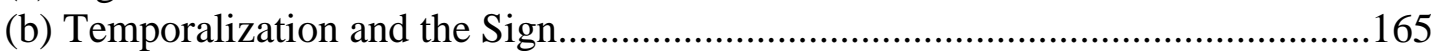

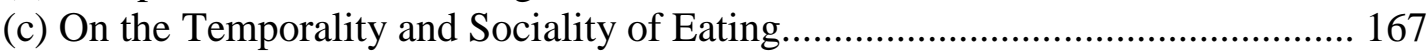

(d) The Predilective and Anamnetic Senses of the Sign............................................170

3. Temporality and Relationship in Early Texts .............................. 171

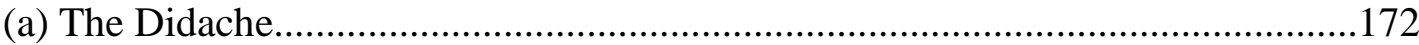

(b)The Eucharist in Luke - Acts..........................................................................175

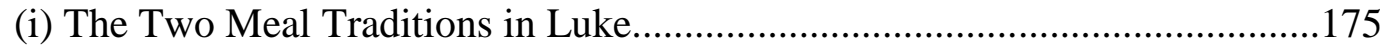

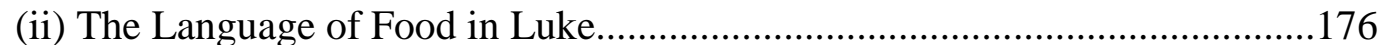

(iii) The New Communicative Life of the Eucharist...........................................176

(iv) The Eschatological Element in Paul's Supper of the Lord.............................176

Part C: Through Metaphysics to Phenomenology ...................................177

1. Thomas' Texts on the Eucharist.................................................................178

(a) The Concealed Depths of Thomas' Texts......................................................178

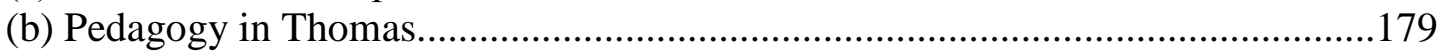

2. God in Himself as Beloved in Lover (Compendium of Theology. 1.45).............183

(a) Thomas' Legacy, after his Visions.................................................................183

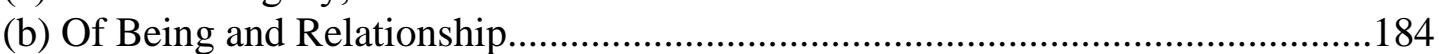

(c) Relational and Temporal Issues Amidst Descriptions of Eternal Being and Identity 
(i) Temporal Relational Solutions in Thomas' Texts....................................190

(ii) Active and Passive Syntheses in St. Thomas...........................................191

(iii) The Act of Relational Acceptance as the Performance of Agency in the Trinity....

(iv) The Predilective Character of Consecration: a Trinitarian Theory of Consecration

Part D: Relationship and the Eucharist....................................................194

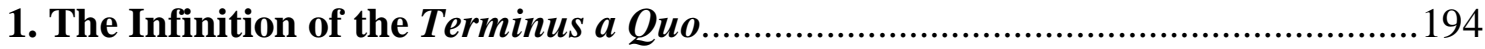

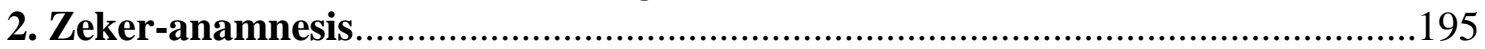

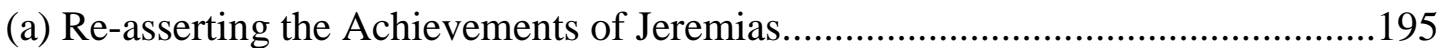

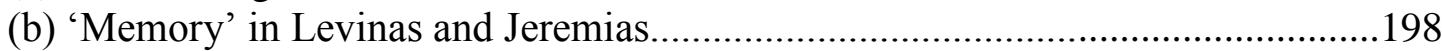

(c) Anamnesis: An Institutional Placement of Zeker-predilection...........................199

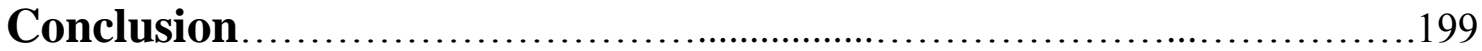

\section{Chapter 4:A Phenomenology of Traditioning ...........................201}

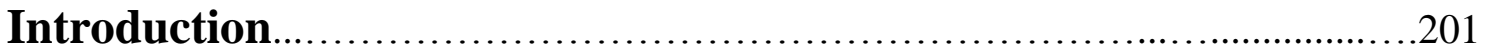

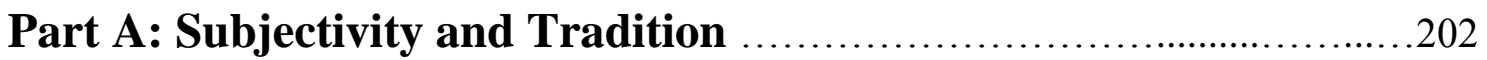

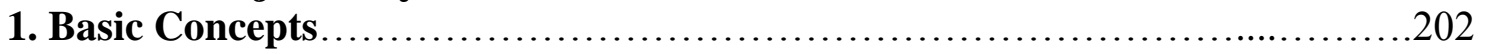

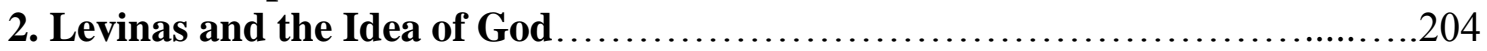

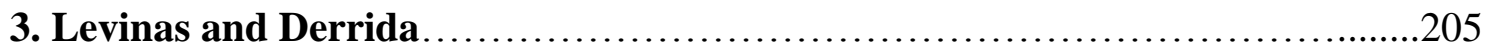

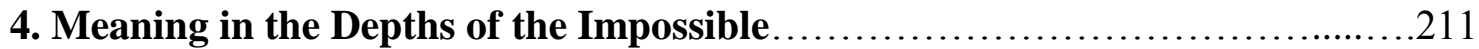

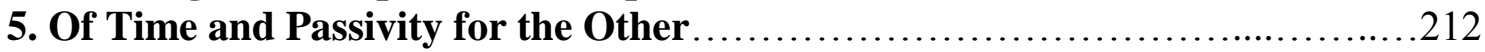

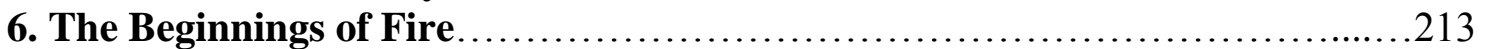

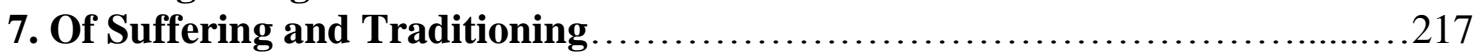

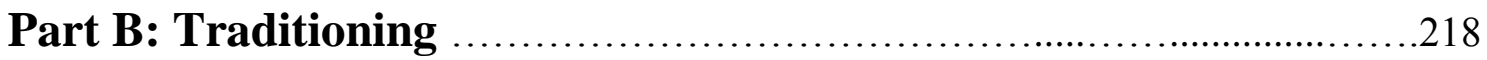

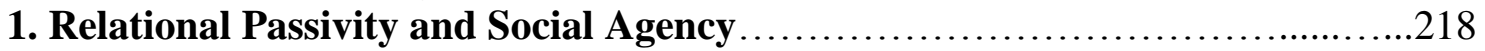

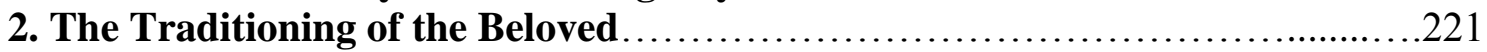

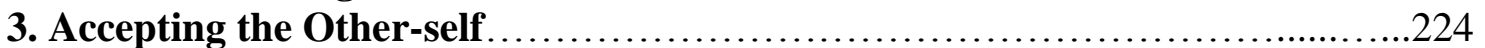

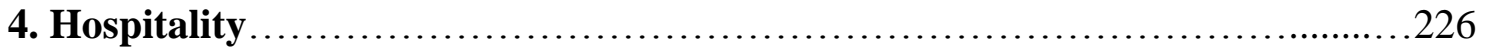

5. Thomas Aquinas and Emmanuel Levinas, union in the passive synthesis........226

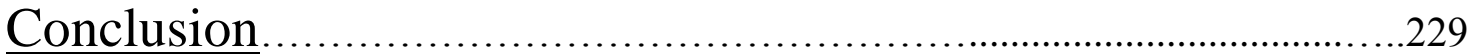

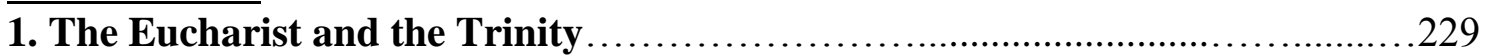

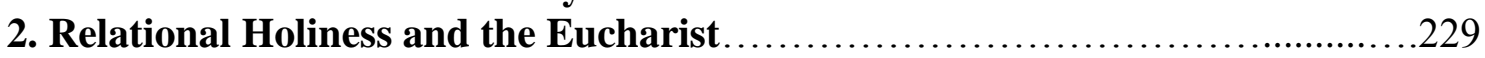

3. The Trinity as Source of Relational Traditioning ...............................235

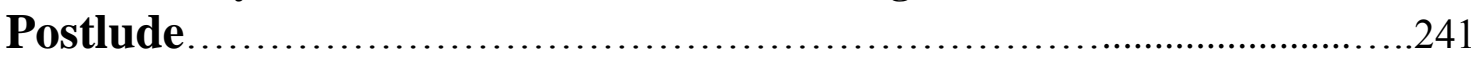

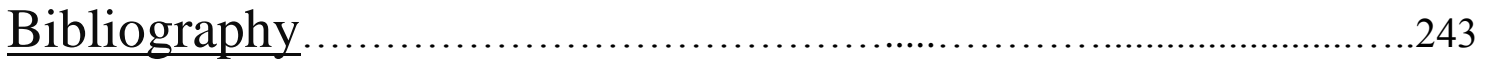





\section{$\underline{\text { Abstract }}$}

This thesis is an enquiry into how relationship differs from identity. It studies the senses of relationship and identity in the history of the Eucharist. The aim of the thesis is to describe how relationship and identity are expressed in the history of the Eucharist, and, by extension, in traditions generally. The thesis reflects on the Hebrew and Greek scriptures, historical celebrations of the Eucharist, Greek and Latin metaphysics, medieval mysticism and phenomenology.

In Hebrew Scripture, a sense of infinite loveableness can be discerned in the expression "yahid". First century Christianity applied this particular sense of "yahid" to Jesus and this sense influenced the way the sacraments of initiation were celebrated. Accordingly, the Eucharist emerged through scripture and traditioning as a sign of infinite loveableness. The eucharistic expression of loveableness produces a sense of relationship which alters the Christian disciple's sense of identity. This alteration becomes actualised through expressions of hospitality and relational traditioning. Through reflecting on the dynamics of relationship and identity in the Eucharist a general phenomenology of tradition begins to emerge.

This study was motivated by the author's belief that a relational theory of traditions and traditioning has not been written. By describing the relational significance of a traditional sign (the Eucharist), a contribution may have been made in two fields: the phenomenology of the Eucharist, and the phenomenology of tradition. 


\section{Acknowledgements}

From Jane Aoina to John Zizioulas a litany of people has inspired me in the way of this thesis. It is on the Eucharist. It is on the meaning of my life. Therefore, from among these life-giving leaders I dedicate this thesis to Jesus, the Lord of the Eucharist. Having reached its end, I now understand why - 32 years ago - my prophetic friend, Joanna Williams, gave me a pen for my ordination present.

Turning to the actual project, it has taken a village to raise this thesis. Three lights shine out in the academic community. Firstly, I am grateful to Professor Paul Morris, for his patience. From many years before the thesis officially began, he listened, read and waited, as my very stretched mind struggled for the gift of coherent thought on the subject. Dr Sara Cotterall's passionate enthusiasm was also indispensable. Her exceptionally generous friendship and professional insight into how to produce a text, amidst all kinds of distractions and social commitments, saved the thesis from falling into chaos. Dr Teresia Teaiwa's passion for a spiritual life full of academic excellence, social justice, art and humour, helped me see beyond the earthly expressions of the Eucharist into the realms she now inhabits. Before she left us, her spiritual depth was already infusing itself into the thesis. Joe Dawson and Dr Sarah Pinto have been so helpful. I only have the most basic editing and computer skills. The thesis would have been impossible without them. They have both been true spiritual companions and supported me from the heart. I am grateful to my many friends who have waited for me to finish this work. From Cardinal Dew to all my dear brother priests, from Anne and Andy to Bev, from Sam and Kathryn to Tiffany Sadlier, thank you for your loving and patient encouragement.

Thank you dear Natalie for the depth of your support and belief, thanks also to Nicola, Simon, Hugo and Harvey. Also, to my very loving nephews and nieces, and your dear children, and Tayte, you have been so encouraging. Thanks to Maurice and Colleen, Barbara and Ron, Margaret, Rae, thank you for nurturing me through life, and especially Stell, you not only kept believing in me, without you I would have died of 
starvation. Finally, to Dougie, Gerald, Gaye, Anne, Bill and Phillip, Don, Mike, Peter and Paddy, and above all Mot and Mercy, thank you, you are the music that never dies. 


\section{$\underline{\text { Introduction }}$}

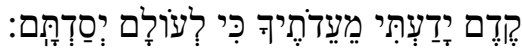

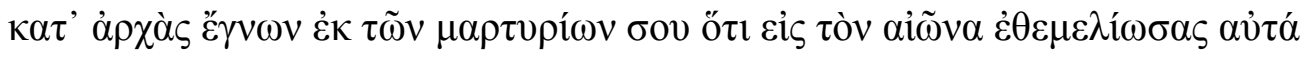

Ab inítio cognóvi de testimóniis tuis, quia in ætérnum fundásti ea

From of old, I have known from your testimonies, that you have founded them forever

- Psalm 119:152

This thesis is a reflection on the meaning of relationships. It argues that the sense of relationship differs from the sense of identity and that the decisive difference is expressed by loveableness. The evidence for this argument is gathered through studies in how the Eucharist ${ }^{12}$ signifies. Through these studies it emerges that not only the eucharist but other traditional expressions of meaning are also formed by the sense of loveableness.

The steps in the argument are developed through an introduction, four chapters and a conclusion. The Introduction exposes the root concern for this thesis, the need to describe how relationship signifies. Responding to this challenge, the first chapter takes the Eucharist, a sign ${ }^{3}$ which sustains a strong sense of social identity, and shows that it

\footnotetext{
${ }^{1}$ In this thesis the upper case "Eucharist" refers to the Eucharist in general, the lower case "eucharist" refers to particular local eucharists.

${ }^{2}$ In this thesis the following factors combine to determine the use of "Eucharist" and "eucharist". Firstly, if an authority in one of the Eucharistic traditions calls a liturgical meal a "Eucharist", it is called a Eucharist in this text. Hence, even though the Didache does not recount a fully formed Eucharist, that liturgical meal was traditionally called "the Eucharist" in its day (Didache 9). Therefore it is called a Eucharist in this thesis, but it is still distinguished from a fully formed Eucharist. In this text, Liturgical meals that are not fully formed Eucharists are occasionally called "eucharists" but only if they are liturgical meals in the first 100 years of the Church's life. Apart from that "Eucharist" and "eucharist" always mean a traditionally authorized imitation of the last supper meal. Eucharist also refers to an invisible mystery of faith. But throughout this thesis, references to that mystery are never independent of the physical event of the liturgical last supper mimesis. No matter how high above the last supper the Eucharist of John 6 might fly, it never ceases to be part of the last supper imitation of Jesus ${ }^{3}$ This thesis uses "sign" to refer to a physically evident event that means something other than its physically evident givenness. The thesis refers to signs that are (i) natural, (ii) verbal or (iii) sacramental. (i) With natural signs, the physical event has a certain function in the world that enables it to imply or express more than its actual physicality. A certain colour of the sky at night implies something other than the colour of the sky. A gift of food or drink, or a ticket to a concert expresses kindness, beyond the
} 
also expresses a strong sense of relationship. Chapter two explores the history of this sign and shows that a struggle between the priorities of relationship and the priorities of identity mark the history of the Eucharist. Chapter three articulates a way in which this struggle may be resolved. It analyses the depth-identity of the Eucharist and demonstrates that the identity of the Eucharist is based in its relationality. In addition, it shows that this relationality signifies as consecrated loveableness. Having arrived at the sense of loveableness in the Eucharist, the fourth chapter reflects on traditional signification, in the Eucharist and beyond. It shows that 'loveableness' is also a necessary and incomparable priority in traditions outside the Eucharist. The thesis concludes by considering ways in which this distinction and this research may be advanced, in the traditions of the Eucharist and in the other scholarly and social traditions.

The Introduction presents the most basic concepts that form this thesis. It is in three parts. Part A describes the issues with which it is concerned. It also articulates some approaches that may simplify the complex subject matter that these issues have produced. Part B identifies the sources through which it explores those issues and identifies the methodology that it applies. Part $\mathrm{C}$ articulates the thesis itself: that the

physically evident givenness. (ii) Words are a particular class of sign. They are physically evident but the physical givenness occurs because they already have a meaning. The sound waves in the air conform with meanings that are expressed through those sound waves.. (iii) The same may be said of sacraments. A meaning is not superimposed on their physical givenness, water, oil; bread, wine. The physical givens are appropriated to the meaning that the sign materials are chosen to express. There is a certain correspondence between the physical givens and the meaning of the sign but the signs do not present the meaning. The meaning chooses the sign. Then the sign materials intimate the meaning that appropriates them. Having made these points it is possible to articulate the most frequent meaning of sign in this thesis. A sign is an intimator of meaning. The most basic and frequently mentioned sign in this thesis is the Eucharist itself. It is often referred to simply as "the sign". This is a habit of the author because of his sense that the Eucharist is a sign that needs no other words to describe it. It is the pure intimacy of immediate meaning. For Levinas the face has the sense of an incomprehensible sign. (Autrement qu'être, 150.) It intimates a meaning, or rather a value. In these respects the Eucharist and the face are relational signs. They intimate meanings. The face, as sign of loveableness intimates non-indifference. It is impossible to be indifferent to the other who approaches in the throes of suffering. A narrative is also a sign. It may be a sign of a certain direction, in the interpretation of events. But also, outside the meaning of the words of the narrative, it signifies a relationship between the author or narrator and his audience. When the anonymous "sign" is used, I have tried to make it clear from the context, what particular sign I am referring to.

At one point Paul's traditioning of the narrative of salvation (1 Corinthians 15:1-6) is compared and contrasted with his traditioning of the sign that is the Eucharist (1 Cor 11:23-6). In both the narrative and the Eucharist there are relational and identifying factors. But the narrative is more equipped to describe a path while the Eucharist is more equipped to communicate a relationship. Hence Paul invokes it to bring the Corinthians to think about their relationships and how they live them. Finally, both, narratives and sacraments, are signs of traditioning. They produce the relational and identifying, or directional, senses that lead and bind traditioning people. 
sense of loveableness provides the radical distinction between relationship and identity and that this sense is evident in the history of the Eucharist.

\section{Part A: The Ultimate and the Emergent Issue: Identity and Relationship - as it Arises through the Eucharist}

\section{The Ultimate Issue}

The ultimate goal for this thesis is to show how the sense of relationship differs from the sense of identity. This issue is immense; it applies in all traditions, with or without connections to the Eucharist. Nevertheless, here it is explored so specifically in the Eucharist that the aim of the thesis may be simply stated as: to demonstrate the distinction between relationship and identity through a study of the Eucharist. But, having accepted this definition, it would be an impoverishment not to acknowledge those sources outside the historically identified Eucharist which also guide the following reflections.

(a) Pannikar and Heidegger: An Initial Approach to the Ultimate Issue

The distinction between identity and relationship is raised here in terms of the Eucharist. But it is also an important question in Trinitarian theology and Christian ethics. Furthermore, it figures throughout the history of Western philosophy and in Eastern religions. As only he could do, Raimon Pannikar has shown how the paradoxical interconnections of identity and relationship figure outside the concerns of Western religion and philosophies. In service to the West and the East he described identity and relationship by developing a phenomenology of "advaitic intuition" 4 . In The Rhythm of Being he describes this intuition of Being, which is the non-dual intuition

\footnotetext{
${ }^{4}$ Raimon Panikkar, The Rhythm of Being: The Unbroken Trinity. Maryknoll, NY: Orbis Books, 2010.
} 
of the plurality in Being. "The advaitic intuition focuses not on the two things to be related......the advaitic intuition focuses on the relationship itself".

But this was not only Eastern thought in Western guise. Panikkar was at home in the practice of Western Phenomenology. Like Heidegger and in conversation with him, he explored relationship and identity in the horizons of language and Being. Panikkar accepted the radical depth of questioning and challenged the superficiality with which the question of the meaning of Being is so often asked. He raised the question of language in this way, "many languages use the verb "to be" to ask about whatever is considered the fundamental issue. In this universe of discourse, the question of Being is the fundamental question". 6 He found the paradoxical dynamics of Advaitic intuition compatible with Heidegger's prioritizing of the question of the meaning of 'Being, ${ }^{7}$. An absolute paradox cannot be expressed through the identification of a conclusion. But through Heidegger's preference for questioning, the paradox of the one and the many could be brought into language without the need for a conclusion. It is through the sense of the invincible question that issues of identity and relationship can be sustained in philosophical discussion.

Panikkar's relational treatment of Advaitic intuition and the Trinity show the relational priority in his work. But there were limits, even to Panikkar's encyclopaedic gift. Firstly, he did not discuss the difference that the Hebrew language and the Jewish sense of the covenant could contribute to his descriptions of revelation. Secondly, Levinas, in Autrement Qu'Être ou Au-delà de l'Essence ${ }^{8}$ and Derrida in L'Écriture et Difference ${ }^{9}$, developed new approaches, that challenge the philosophy of Being ${ }^{10}$ through which Panikkar's “Advaitic intuition" and Heidegger's phenomenology of Being were thought ${ }^{11}$. They contested the ultimacy of the meaning of 'Being'. The point is expressed in the following quotation from Derrida, "writing is the anguish of the human spirit, experienced from the side of solitude and human responsibility; from the side of

\footnotetext{
${ }^{5}$ Panikkar, Rhythm of Being, 30.

${ }^{6}$ Panikkar, Rhythm of Being, 68.

${ }^{7}$ Heidegger, Sein und Zeit. Tübingen: Max Niemeyer Verlag, 2006.

8 The first edition of Emmanuel Levinas' Autrement qu'être ou au-delà de l'essence [Otherwise than Being or Beyond Essence] was printed by Martinus Nijhoff, La Haye in 1974. This thesis will refer to the Livre de Poche version printed by Kluwer Academic, Paris, 1990.

9 Jacques Derrida, L'écriture et la difference. Paris: Éditions du Seuil, 1967.

10 In this thesis, upper case "Being" refers to the "Being" in its universal sense, the lower case "being" refers to the being of particular beings.

11 "our aim in the following treatise is to work out the question of the meaning of Being and to do so concretely". Martin Heidegger, Being and Time, trans. Joan Stambaugh, 1996, 1.
} 
Jeremiah, submitted to the dictation of God ('take a book and write there all the words I have said to you')"'12. This does not articulate a profoundly uniting sense of the word 'Being'. It articulates a crisis of relationship and the problem of speaking from a "side" of that relationship. It evokes the sense of an infinite distance between a meaning and what becomes of that meaning, as it is communicated in the world.

The quotation from Derrida articulates the endeavour of this thesis; to articulate a sense of communicated meaning, a victory of social communication through reflection on the Eucharist. To establish the sense of a communicated meaning, the act of communication is not presumed to express the fullness of Being but the gift of relationship. Levinas and Derrida show that it is necessary to allow relationship to signify beyond, rather than, along with the sense of identity that forms the sense of the participle 'Being'. But, there is a further challenge to be addressed. With regard to these traditions of philosophy and religion, neither Derrida nor Levinas articulated the relational sense of traditions. With this challenge in mind, this thesis explores a traditional sign, the Eucharist, to discern whether it traditions a sense of relationship, greater than the sense of identity that it also conveys.

(b) Levinas and the Relational Revolution: A Developing Approach to the Ultimate Issue

There is a significant methodological challenge in describing any event as a sign of relationship rather than of Being, especially the Eucharist. At some point, it is necessary to leave the familiar method of describing beings and the somewhat familiar method of describing the Being of beings, and to describe relationship beyond being and the Being of beings. Although the sense of a relationship outside a Being is found as long ago as Augustine's De Trinitate $^{13}$, that sense was not thoroughly explored until Levinas wrote Autrement qu'Être ou Au-delà de l'Essence. This is a revolution. Formerly, issues of ontology have been so important in the history of the Eucharist that the most debated topic in its history has been about the being of the sign. Is its ontological identity

\footnotetext{
12 "L'écriture est l'angoisse de la ruah hébraïque éprouvée du côté de la solitude et de la responsabilité humaines ; du côté de Jérémie soumis à la dictée de Dieu («Prends un livre et tu y écriras toutes les paroles que je t'ai dites.»)," Derrida, L'écriture et la difference, 19. Derrida quotes Jeremiah 36:2.

13 "Sed quia et pater non dicitur pater nisi ex eo quod est ei filius et filius non dicitur nisi ex eo quod habet patrem," Augustine, De Trinitate 5.5. These uses of "ex eo" indicate Augustine's reasons for teaching that the relationality of a being arises outside the Being of that being.
} 
changed from the substances of bread and wine into the substances of the body and blood of Christ or does it remain the same? Even today, this may still be the biggest obstacle to Ecumenism. However, there is a greater challenge for thought. The challenge is to think the relational sense of the Eucharist, its biblical sense as an expression of covenant love.

Although the distinction between ontology and relationship has only been achieved recently; in Otherwise Than Being or Beyond Essence, the confrontations between ontology and relationship are epoch making. Voegelin wrote of Judaism and Hellenism, "the two experiences [of immediacy under God] differ so profoundly that they become articulate in the two different symbolisms of Revelation and Philosophy." By "the two experiences of immediacy under God" Voegelin is referring to Jewish covenantal revelation and Greek Philosophy ${ }^{14}$ This thesis explores the impact of the philosophical legacy of Greece on the Eucharist and on traditioning generally. It will be explored with regard to the influence of ontological on relational priorities. In its two thousand year history, the Eucharist, a sign of covenant relationship, has barely been discussed as a radically relational sign. But, since the second century it has been discussed as the sign of an ontological change ${ }^{15}$. The swift movement away from relational thinking about the eucharistic sign seems to be due to the establishment of Greek ontology at the basis of Christian thought. The idea that being can be based in relationship does not make sense to ontology. Yet this thesis argues that, arising prior to the influence of ontology, the traditioning of the Eucharist bases Being in relationship.

Therefore, at the commencement of this thesis, the establishment of ontology poses a problem: how to make relational thought intelligible in an ontologically based world. That must be solved well before this study gets to the end. From the outset this thesis expresses relational thought, therefore relational thought needs to be intelligible at this very point: the beginning. Certainly, other philosophers have written relational and counter-ontological thought, but they generally arise in difficult texts filled for a specialist audience. Many post-Heideggerians are notoriously difficult to understand. But this thesis concerns issues beyond specialist discourse. It supports the popular

\footnotetext{
${ }^{14}$ Eric Voegelin, Order and History, Vol 2 The World of Polis, 67.

${ }^{15}$ Justin Martyr, First Apology, chap. 66 - "For not as common bread and common drink do we receive [the Eucharist]; but in like manner as Jesus Christ our Saviour, having been made flesh by the Word of God, had both flesh and blood for our salvation, so likewise have we been taught that the food which is blessed by the prayer of His word... is the flesh and blood of that Jesus who was made flesh."
} 
pastoral gift of the Eucharist. It seeks to articulate in a popular way; that 'this sign is about relationships rather than Being, about our relationships and relationality rather than our identities.' Therefore, it seeks to render incomprehensible abstractions pastorally accessible.

What a battle! Incomprehensibility is a charge Levinas made against himself! Likening his philosophical endeavours to climbing a mountain he wrote: "the difficulties of this climb - with its failures and resumptions - are inscribed in a writing which, without doubt, also attests to the breathlessness of the explorer." 16 On the other hand, Levinas got away with it. He had the mastery of the philosophical tradition that enabled him to demonstrate that he could understand what he was talking about, however difficult it may have been for his reader. But how can this thesis, which is an exercise in Levinasian reflection, not also attest to the breathlessness of this author and the steepness of the ascent? Only, I am a pastor, without the luxury of an established reputation for translating Heidegger and Husserl. If I want to be understood, I have to be as clear prima-facie! Therefore, this Introduction is pre-occupied with making concepts, extremely unfamiliar to many people, as familiar as possible, in as short a time as possible. In other words, the task for this Introduction is to make Levinasian and postLevinasian reflection, - which I call "relational reflection" - as accessible as possible.

But there is consolation. Levinas reached a summit. He achieved a way of distinguishing discourse about relationship from discourse about Being. Finding ourselves lifted to this summit by his work, we have the opportunity to stop, rest, gather some unused resources, gain some breath and then travel on more easily.It also means we are learning from, but not repeating Levinas. He has brought philosophy to a new beginning. The crucial factor is to learn to accept what the new starting place has to offer. We begin with relational reflection.

\footnotetext{
16 “Les difficultés de l'ascension -et ses échecs et ses reprises - s'inscrivent dans une écriture qui, sans doute aussi, atteste l'essoufflement du chercheur." Levinas, Autrement qu'être, 10.
} 
(c) Approaching the Issue through Relational Reflection - Mind, Mouth, Voice and Ear

(i) The Relational Genesis of Language

The difference between ontological reflection, which is familiar throughout the history of philosophy and the Eucharist, and relational reflection can be understood by examining the mind-word unity in each kind of reflection. In both forms of reflection, the material word provides the content for the reflection.

In the ontological kind of reflection, the mind-word unity identifies language as an expression of the mind of the self, spoken through the mouth or written on the page. But in the relational kind of reflection, the mind-word unity identifies language as an expression of the mind of another, received by the ear. The former is a 'mind-word' unity based in identity, since the word is identified in the mind before it is expressed in speech. But the latter is a 'word-mind' unity based in relationship, since the word signifies outside the mind and comes to hearing through the horizons of relationship, before it can be identified by the mind. Beginning outside the listening ear of the self, the word-mind unity is formed by the relationality of the audial bodily mind.

These differences may be clarified further. Beginning with the mind, ontological reflection proceeds though the mouth (or the pen, keyboard or paint brush). It is understood as an expression of the self and it expresses the identity of the speaker. The speaker who thinks the word, has already thought it prior to its expression, without necessarily expressing it socially. Relational reflection begins with a word outside the mind. The listener who hears the word has not heard it before. It arrives whether or not the listener wants to hear it. Furthermore, because the word arises outside the listener, the hearing model of meaning exhibits the significance of the area between the listener and the speaker. The meaning of the word arises between the mouth of another and the ear of the one who hears. It signifies relationship simply through its occurrence. The meaning of the word develops relationally as long as speaking is bound to listening.

\section{(ii) A Brief Analysis}

In analysing this description of the relational occurrence of meaning, four matters demand attention for the sake of this thesis. Firstly, although the ear based sense of meaning models relationship more comprehensively than the speech based sense of 
meaning, the two ways of describing the occurrence of meaning are not mutually exclusive. Generally, a person who speaks also listens. A person who listens also speaks. Therefore, to be thoroughly comprehensive, it is necessary to develop a synthesis of the two kinds of meaning expression. This encapsulates the matter that absorbs this thesis. It concerns the dynamics between a relator and a related to.

Secondly, the different occurrences of meaning, speaking the word of the self and hearing the word of another, are facts of existence not simply metaphors. They are historical emphases that vary from person to person in the course of a conversation. They also vary in the works and eras of philosophy and social traditions. The different models are evident in the distinction between Aristotle's animal that speaks, ${ }^{17}$ and the priority Levinas gives to the voice that comes from outside the self, from the horizons of the other ${ }^{18}$. With its roots in ancient Greek thought, the philosophical and theological tradition of the West applies the spoken-word model more habitually than the heardword model. This thesis does not oppose the spoken-word model of meaning but it does oppose the emphasis it has received. The hearing model of meaning, which derives from the phenomenology of relationship, is more comprehensive. It prioritizes the comprehensive traditioning ${ }^{19}$ of language rather than the individualized creativity that prioritizes the act of speaking.

Thirdly, even though the production of meaning through the mouth and the ear is historical, the models are also somewhat metaphorical. The model of meaning that prioritizes speaking is also a model of agency based meanings, it takes its form from the act of speaking. In this text, agency based meaning is generally referred to as “ontology". The model of meaning that prioritizes hearing is a model of passivity based meanings, it takes its form from the passivity of hearing. Here, passivity based meaning is generally referred to as 'relational reflection'. 'Relational reflection' is phenomenological reflection, but phenomenology may also include ontology. Therefore, this thesis treats ontology as one area of phenomenology and relational reflection as another.

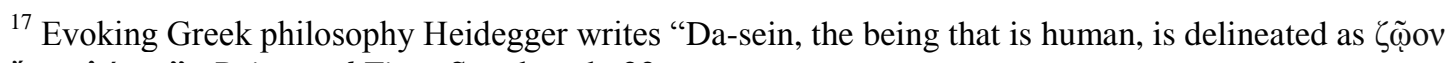

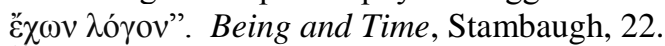

${ }^{18}$ Levinas, Autrement qu'être, 280, - "la sens d'autrui est irrécusable... Une voix vient de l'autre rive."

${ }^{19}$ In this thesis the restoration of the otherwise obsolete verb "traditioning", is intended for two reasons, firstly to translate the Greek word group " $\pi \alpha \rho \alpha \delta i \delta \omega \mu l-\pi \alpha \rho \alpha \dot{\delta} \delta \sigma \iota \varsigma$ ", "traditioning-tradition" (cf. chap. 1) and secondly to transpose Levinas' general philosophical distinction between "the Saying and the Said" ("le Dire et le Dit") into the historical environments of living traditions.
} 
Fourthly, the relational sense of meaning exhibits the area between the source of meaning and the completed expression of meaning. The speaker and the hearer differ from each other but there is also the difference that is between them and is neither of them. The difference between them separates the hearer and the speaker. Both the hearer and the speaker are powerless to overcome the difference of the between. This difference is between them and outside the being of each of them. It is not in them so that they can comprehend or control it. For this reason, the communicating parties are helplessly exposed to the difference between them. This relational and passive depth of meaning cannot be defined by speaking, it can only be learned by listening.

In contrast to the relational sense of meaning that is outside each being and between them, the identifying sense of meaning that arises through speaking, refers to a unity of being. The source of meaning and the completion of the expression of meaning are in the one being that speaks. There is no spatial or temporal difference between the mind that thinks and the mouth that speaks the meaning. They are spatially and synchronically united. But in the determination of meaning that comes with hearing there is a spatial difference between the mouth of the speaker and the ear of the hearer. There is also a temporal difference between the speaker's expression of the word and the hearer's reception. The speaker and the hearer are spatially and temporally distinct. These differences are increased when the expression of meaning is produced in a literary document. Then the one producing the word and the one receiving it may be diachronically related the over a span of thousands of years.

\section{(d) Applying the Above Distinctions in this Thesis}

As may be obvious from the above paragraphs, this thesis sets out to deconstruct the traditional model of meaning, based in the identity of a speaking agent. With the help of the Eucharist and Levinas, it articulates a model of meaning, based in the relationality of a listening patient. The mind-mouth model of meaning endorses a kind of speech that does not rely on listening. But the ear-mind model of meaning implies a learning process and a world of meaning outside the mind of the listening subject. The listening mind hears and thinks the word of the other.

The pages that follow are based in this mode of relational reflection. They are formed through a kind of devotion to listening. The sense, or theory of meaning that they 
articulate is that: signification, or the meaning of signs, is not found in the acts of a speaking identity but in the patience of a listening relationality. Or rather, meaning is in the relationality of the word. It exists between the mouth that speaks and the ear that hears. The voice is governed by the sensitivity of the other's ear. The agent who speaks is affected and guided by the sensibility of the patient's ear.

But this relational passivity is not inert. It is influential. The ear gives rise to communication. Beyond words, the voice and language of silence resounds from the ear of the one who listens. There is expression, Saying, in the vulnerability of the ear. The cry of the ear may be expressed: "I belong to your voice, relate to me in a voice that heals, a voice that gives me the freedom to hear". Speech and expression are commanded to love the ear, the sensibility of the other. This is the language of the ear. Gift of the loveable to the one who longs to love, the ear silently calls for the voice of the other, it communicates the desire for speech and imperiously invokes language. The loveableness of the ear evokes the love that speaks.

\section{(e) The Difficult Revolution}

An implicit understanding of the person is expressed in these models. "Person" derives from the latin "per-sona" 20 " "through-sound". The sense of a person, resonates with the sense of their voice. The voice bears the mind and heart of the person. But in the model of the speaking agent, the meaning of the word is in the voice of the self, it is autocthonous. For the speaking subject, the meaning of the word is in the voice of the subject. For the listening subject, the meaning of the word is in the voice of the other. Listening declares the relationality of the voice and its words.

This leads to a radical question that pre-occupies this thesis. Is the idea of mind that governs the discourse on meaning predominantly the idea of a speaking mind or a listening mind? Is it a mind that is formed through the voice of the self or the voice of the other? The questions confront a theological and philosophical legacy in which the meaning of the word is formed by the one who speaks. Contrary to this legacy, this thesis begins with the sense that the meaning of a word is formed by the relational horizon and the sense of the other. These come to mind through the one who hears. The

\footnotetext{
${ }^{20}$ Skeat, Walter W, Concise Etymological Dictionary of the English Language (1911), Oxford University Press, New York, 1984, 385.
} 
relational gift of meaning figures, not only for the one who hears but also for the one who speaks.

The relational difference between the parties is like the sound chamber of a guitar or a cello. It provides the silence through which one sound and one meaning may be distinguished from another. As much as the one who listens, the one who speaks also relies on the silence of difference that separates the sounds, the silence of the between. The one who speaks, while attentive to the gift of silence, speaks for the sake of the ear. The ear is the beloved of the voice. For the sake of the ear, the voice does not always speak according to the logic of the mind. The voice is also concerned with sensibility. It may speak, or prefer to be silent, out of care for the vulnerability of the ear. The ear provides a distinction between the self-empowering and the vulnerable mind. For love of the vulnerable, the mind changes its voice. It speaks predilectively, not caring that its meaning is not expressed in the present, but thankful for the promise of a response, a promise given by the ear of the other.

\section{(f) Levinas and Thomas Aquinas}

But the relationship between the mind that speaks and the mind that hears is not always harmonious. Relationships are not like objects. They rely on the creativity of subjects who are willing to relate. For this relational creativity, it is necessary for the respective parties to both listen and speak. At the outset, therefore, this thesis is in the throes of a difficult revolution. It doesn't refer to what exists but to what may exist through relational creativity. It considers how to discern the meaning of hearing and speaking through their power to create relationship. It concerns how to discern the meaning of passivity and agency through their ways of expressing relationship.

This task of discernment is expressed throughout the thesis but its strongest expression is in chapter three. In that chapter, Thomas Aquinas' doctrine of the Trinity - which has always been treated as a speaking Trinity (a Trinity of 'pure act') - is shown to be, above all, a Trinity of hearing (a Trinity of pure patience). Late in his life Thomas' gift of attending to the voice of the other was so great that, as his revelations of the Eucharist and the Trinity approached their ultimate depth, he could suddenly "write no 
more" 21 . The great thinker of pure agency was absorbed in the overwhelming passivity of an infinite revelation. If he hadn't suffered an untimely and accidental death, he might have found a way to write of the things he had seen and heard. It is impossible to know. However, in a way that may be less than mystical, philosophy is finding the eloquence to extol, not only agency but also passivity. From the beginning to the end of his philosophical life, Levinas gave utterance to a sense of infinite passivity which may well increase the eloquence of mystical reflections. This thesis seeks to build relationships between the occurrences of listening-speech revealed in the writings of Aquinas and Levinas.

Responding to this new opportunity, the following thesis seeks to articulate the horizons of the Eucharist, in both its passive and active expressions of sense. This may lead to a synthesis of Levinas and Aquinas, or at least a common field of discourse for mediaeval thought and phenomenology. The high middle ages were, perhaps, the most influential era in the formation of the contemporary Eucharist, and the Eucharist is the expression of a tradition. Therefore, a contemporary reflection on the Eucharist must include some appreciation of the relationships between the Eucharist today and the Eucharist in its past. The demands of that task and the abilities of this enquirer stand in stark contrast, nevertheless, this is a step that needs to be taken. In these pages that step can at least be envisaged and tested. Even the anticipation of such a synthesis encourages new expressions of relational thought, discourse and practice. This thesis is an effort to contribute to such new journeys in the gift of relationship - the revelation of loveableness.

\section{The Emergent Issue}

While the ultimate issue for this thesis is the difference between relationship and identity, the first practical issue is to find some accessible references to this distinction. Where can an historically evident occurrence of the distinction be found? In one sense, it is easy to find it. Language itself involves both reference and communication. Communication and reference are always bound together in discourse. Communication

\footnotetext{
${ }^{21}$ For an in depth study of Thomas' mystical revelations see, Peter A. Kwasniewski, A Tale of Two Wonderworkers: St. Nicholas of Myra in the Writings and Life of St. Thomas Aquinas, Angelicum 82, 2008, 19-43
} 
expresses the sense and value of the relationship between the communicating parties while, reference identifies matters for the sake information. Thankfully, the Eucharist expresses both kinds of sense and consequently it takes up most of this thesis. Therefore, the question through which the difference between relationship and identity emerges in this thesis is: how do relationship and identity signify in the Eucharist? This is an option among many candidates that express the difference between identity and relationship. But it is impossible to explore all the signs of all the cultures and traditions, therefore I have taken the one option I am capable of; to explore a sign from my own tradition: the Eucharist. Whatever the sign and the tradition, the challenge remains the same, to discern the ways relationship and identity differ. However, I am more equipped to describe the Eucharist because I am already familiar with it through my personal religious history.

The option for my own tradition is not intended to seal the discussion off from other traditions. Rather it is to open it up and promote conversation among traditions, concerning the ways relationship and identity are expressed in those traditions. As the thesis proceeds the hope for a sense of relationship, greater than our identities, may only appear in the text from time to time. But in hidden ways that sense attaches itself to this thesis and brings forth - more than words can contain - relationships with other texts, other traditions, other people. This may lead us a little further into our great awakening, a heaven that comes through the face of the other, "truly I say to you, when you did this to the least of my brothers and sisters, you did it to me" ${ }^{, 22}$. Following the spirit of that parable (Matt 25:30-46), this thesis is inspired with hope in an all-embracing infinite that allows the flames of its gently falling brilliance to animate the histories of our traditions. In the pages that follow the sovereign inspiration of this thesis may be mentioned only little. Nevertheless, its attraction is always in mind.

(a) Phenomenology and the Eucharist

(i) The Contribution of Phenomenology to Christianity and the Eucharist

For some, phenomenology may seem remote from the ancient gift of the Eucharist. However, it is employed in this thesis to discover the interconnections and differences

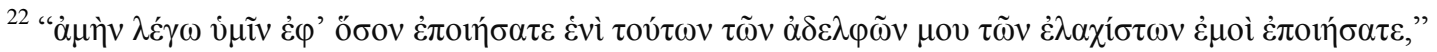
Mt 25:40.
} 
between the Being of beings and the relationality of beings. This topic, even though it arises through phenomenology, exposes a profoundly eucharistic concern. Whether or not a person believes in transubstantiation it is still necessary to acknowledge that the being of the sign and the relationality of the sign provide their respective contributions to the sense of the sign. This distinction may have been forgotten, or may have never figured prominently in the history of the Eucharist, but it is an inescapable dynamic in its history. Phenomenology offers a way to explore it.

The lack of reflection on the relationality of the sacrament ${ }^{23}$ has a history which goes back at least as far as the middle of the third century. That was long before the arguments about transubstantiation, which began in the ninth century ${ }^{24}$. At the beginning of the twenty-first century the challenge remains, to articulate a radically relational sense of the Eucharist. Almost eighteen centuries have passed, in which the distinctly relational sense of the sign has been neglected.

An emphatically ontological approach to the Eucharist may produce the view that the distinction between identity and relationship is not necessary where the Eucharist is concerned. But such an understanding can only result from inadequate reflection. How can a traditional sign not express relationship, in a way that distinguishes it from Being? How can it be satisfactory to presume that all relational issues are comprehended by ontology, so long as the ontology is deep enough? No ontology can be deep enough to comprehend relationship because relationship is different to ontology. The being of a being, its ontological identity, does not comprehend the relationality that alters that being. Augustine is remarkable because he refers to this distinction in his trinitarian treatment of the matter, relationship occurs because one being is outside - "ex eo" another.

\footnotetext{
${ }^{23}$ The word "sacrament" is used in conventional theological ways throughout the thesis. If "the sacrament" is used it either means the Eucharist or a particular sacrament which is clear from the context. ${ }^{24}$ On the Carolingian Controversy and the enduring issues it formed, see Patricia McCormick Zirkel, "The Ninth-Century Eucharistic Controversy: a Context for the Beginnings of Eucharistic Doctrine in the West", Worship (68), 1994, 2-23.

25 "Sed quia et pater non dicitur pater nisi ex eo quod est ei filius et filius non dicitur nisi ex eo quod habet patrem," Augustine, De Trinitate 5.5.
} 
(ii) The Significance for Christianity

Describing how the eucharist expresses identity and relationship is, therefore, valuable for several reasons. It is significant for Christianity. The eucharist is the only ceremonial meal that has survived since the third century. In the era prior to that, which it shared with the agape meal, the Eucharist became, very quickly - if not always - the most significant of the partners in the agape meal. Studies in the history of the early Church show how much the development of the early Church relied on the Eucharist. This was so to such an extent that Christianity probably would not have survived without the Eucharist. Taylor and Nodet put this succinctly in their work The Origins of Christianity: An Exploration. ${ }^{26}$ "It is understandable that when the disciples start off again [after the betrayal and death of Jesus], they hold on to the elements which had formed their identity and their companionship with Jesus, namely the ritual gestures to which they were accustomed." 27 Arguments have also been made that the narrative pericopes in the Synoptic Gospels became available and received their structures through the practice of recounting them at eucharistic celebrations ${ }^{28}$.

Such arguments are voiced most strongly by theologians and historians in the Catholic and Orthodox environments. Accordingly, the Second Vatican Council defined the Eucharist as "the source and summit of the whole Christian life" 29 while the Great Holy Council of the Orthodox Churches wrote that the eschatological community of the Church comes into existence "through the eucharist" 30 . But, while it is to be expected, that the liturgical meal has such great importance in the sacramental traditions, the eucharist also has importance outside the major sacramental traditions. Especially in his later work Barth taught that the proclamation of God's Word forms the sacramental life of the $\mathrm{Church}^{31}$, nevertheless he had also taught that the Eucharist brings a unique and

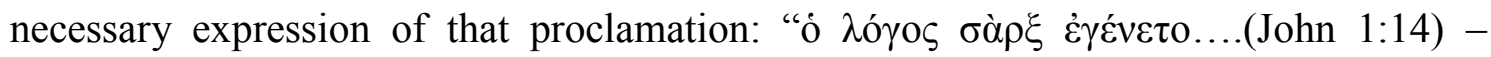
preaching, too, can and must say this. But in a way which preaching can never do, the

\footnotetext{
${ }^{26}$ Etienne Nodet and Justin Taylor, The Origins of Christianity.

${ }^{27}$ Nodet and Taylor, Origins of Christianity, 123.

${ }^{28}$ Denis Farkasfalvy, "The Eucharistic Provenance of New Testament Texts." In Rediscovering the

Eucharist: Ecumenical Conversations, ed by Roch A Kereszty, 27-51, Paulist Press, New York, 2003, $27-$ 51,cf especially pp. 29-39.

29 "sacrificium Eucharisticum, totius vitae christianae fontem et culmen," Second Vatican Council, Lumen Gentium, 2.11.

${ }^{30}$ Article 1, Decree 4, The Great and Holy Council of the Orthodox Churches - Official Site. https://www.holycouncil.org/, accessed 26/9/2017.

31 "proclamation is the sacrament, i.e., the symbolical act which is carried through in the Church as directed by the biblical witness of revelation." Karl Barth, Church Dogmatics, Vol. 1, Part 1, 56.
} 


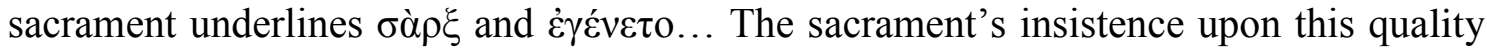
in sign-giving is its special feature as compared with preaching and its special feature..." ${ }^{\prime 2}$. Nor is this surprising. It is normal for the scriptural traditions to give a unique priority to the Eucharist, because, as the teachings in John 6 and the five last supper accounts testify, scripture prioritizes the eucharist. To this traditionally given practice Paul applies the highest of all epithets. It is "dominical", "the supper of the

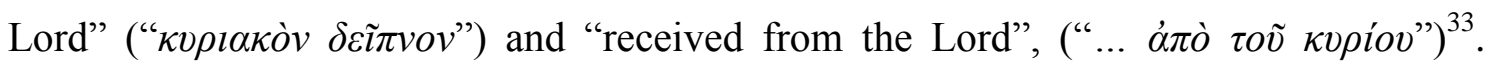
Whether on traditional or scriptural bases, and especially when these are combined, the eucharist carries the greatest significance for Christianity.

(iii) The Significance of Studying the Eucharist for Phenomenology

But a phenomenological reflection on the Eucharist also contributes to phenomenology. Firstly, it is a sign of loveableness and it expresses the difference between the sense of relationship and the sense of identity. This difference is clearly voiced in the biblical words that articulate the meaning of the sacrament. They articulate identity and relationship in the one sign. "This is my body", "this is my blood", "for you" 34 Therefore, the Eucharist offers a material opportunity for exploring the dynamics involved in the distinction between identity and relationship.

Secondly, the phenomenological movement has yet to achieve a phenomenology of tradition. But the eucharist is a traditional sign. Therefore, it offers a field of exploration through which a phenomenology of tradition can be advanced. This challenge will be taken up in Chapter 4.

Thirdly, the eucharist is a sign which exists in many different cultures. Therefore, it brings with it many different social horizons through which the differences of identity and relationship may be explored. This involves local and global issues of meaning and justice. William Cavanaugh ${ }^{35}$ has described ways in which the eucharist was crucial in forming popular resistance to the Pinochet regime in Chile in the 1980s. In contrast Pā Henare Tate's work (He Puna iti I te Ao Mārama: A Little Spring in the World of Light) challenges traditional European practitioners of the eucharist to celebrate rather than

\footnotetext{
${ }^{32}$ Karl Barth, Church Dogmatics, vol. 1, part 2, 230

${ }^{33} 1$ Cor 11:20 and 23.

34 "vi $\pi \dot{\varepsilon} \rho \dot{v} \mu \tilde{\omega} v " 1$ Cor 11:24-25.

35 "I draw on the resources of the Eucharist", William Cavanaugh, Torture and the Eucharist, 2.
} 
resist the ways traditional Māori spirituality offers itself to indigenous celebrations of the Christian liturgies.

Fourthly, miracle eucharists figure in the history of the Eucharist. One of the first references to miracle eucharists was made by Cyprian, about the middle of the third century. ${ }^{36}$ Since then reports of miracle eucharists have punctuated the history of the tradition. Over the last 40 years miracle eucharists have been submitted to advanced forensic analysis. The results defy scientific explanation. In Unseen, Ron Tesorioro and Lee Han, report contemporary scientific findings on extraordinary eucharistic elements. They have spontaneously become living heart tissue or blood and have survived for centuries. ${ }^{37}$ They describe three such miracles. ${ }^{38}$

These phenomena demand discussion. The most famous is the miracle of Lanciano. At the altar, while a priest was saying mass in Lanciano, Italy, about $750 \mathrm{CE}$, the bread and wine changed into empirically evident flesh and blood. The physical substances remain to this day ${ }^{39}$. In Unseen, Tesorioro and Han gather convincing scientific documents. Even though, they are neither scientists nor philosophers, the book exposes neglected scientific facts and the documentation in their appendices consists of peer-reviewed empirical research. On another level, Miri Rubin has discussed the relationship between miracle eucharists and the social structures of the middle to late middle-ages ${ }^{40}$. This raises the issue of connections between religious beliefs and social structures. ${ }^{41}$ It also concerns the difference between evidence and the applications of that evidence in a broader social narrative. But the uses and abuses of evidence to serve established social narratives is not limited to the middle ages. The evidence of a miracle eucharist in Sokolka, Poland, was rejected by university administrators due to the imposition of their secular ideology on the research. ${ }^{42}$ In terms of the phenomenology of science, doctrinaire religion and doctrinaire denunciation of religion pose very similar problems.

\footnotetext{
${ }^{36}$ Cyprian, Treatises, Treatise 3, para. 25-26. Translated by Robert Ernest Wallis. From Ante-Nicene Fathers, Vol. 5. Edited by Alexander Roberts, James Donaldson, and A. Cleveland Coxe. Buffalo, NY: Christian Literature Publishing Co., 1886. Revised and Edited for New Advent by Kevin Knight. www.newadvent.org/fathers/050703.htm. See also Eucharistic Miracles by Joan Carroll Cruz, xviii.

${ }^{37}$ Ron Tesoriero and Lee Han, Tesoriero, Ron and Han, Lee. Unseen New Evidence: The Origin of Life Under the Microscope. Kincumber, NSW: printed by Ron Tesoriero, 2013.

${ }^{38}$ Unseen, 43-77

${ }^{39}$ Unseen, 73-77

${ }^{40}$ Miri Ruben, Corpus Christi, Cambridge University Press, Cambridge, 1991.

41 "The late mediaeval language of religion posited certain dispositions of power, as both natural and necessary, and thus, by association, an ideology which suggested this was so." Corpus Christi, 358.

${ }^{42}$ See Tesoriero and Han, Unseen, 68-71.
} 
On a terminological matter, this thesis distinguishes between "miracle eucharists" and "eucharistic miracles". The former refers to eucharistic elements which exhibit extraordinary phenomena and the later refers to extraordinary phenomena in the environment of a eucharistic celebration rather than in the elements themselves. Sudden healings at a mass are examples of what this thesis calls "eucharistic miracles". In Proclaim with Wonders, Father John Rea writes of miracles of healing that he has witnessed during masses that he has celebrated. ${ }^{43}$

This thesis concentrates on the first two issues above, the distinction between relationship and identity in the revelation of loveableness, and the need for a phenomenology of tradition. But this is not to neglect the other issues. Rather, it explores the philosophical issues that influence the third and fourth topics mentioned above.

\section{Part B: The Areas of Research and the Methodology for this Thesis}

\section{The Areas of Research}

(a) The Three Disciplines through which this Thesis Develops; History, Philosophy and Spirituality.

In order to sustain a focus on the different expressions of identity and relationship in the history of the Eucharist, this thesis binds the occurrences of identity and relationship together through historical, philosophical and mystical reflections on the sacrament. This enables a focused and thorough exposure of the issues in a relatively short document. The approach shows obvious sympathies with Von Hugel's doctrine of the three inter-related elements of religion; the institutional-historical, rational-doctrinal and emotional-mystical $^{44}$. Through von Hugel's "three elements of religion" it becomes possible to unite the three strands of history, philosophy and mysticism into one sustained reflection on the Eucharist.

\footnotetext{
${ }^{43}$ Cf, John Rea, Proclaim with Wonders, 18.

${ }^{44}$ von Hügel, Friedrich, Mystical Element of Religion, 50-82.
} 
(i) The Emergence of the Distinction between Identity and Relationship in the History of the Eucharist

The first topic involves the ultimate concern of this thesis, the meaning of the eternal covenant that scripture discloses for Jews and Gentiles. Reflection on the history of the Eucharist offers new ways of sharing this sense of covenant between its significantly different participants. But while the future aspiration forms an ultimate goal for the thesis, the goal figures because the differences are expressed in history. Therefore, the complex development of differences between Judaism and Christianity need to be accepted as a starting point in the history of the Eucharist.

This thesis probes the scriptural sense that the eucharist began as a predominantly Jewish covenant meal and ended as a predominantly Greek meal. The former prioritized relationship the latter prioritized identity. This transition is explored in chapter $1^{45}$. With Cyprian, in the middle of the third century, the historical and metaphysical identity of the Eucharist had become its determinative sense. ${ }^{46}$ By the end of the fourth century its metaphysical sense had become global and supremely influential. Commenting on Ecclesiastes 2:24 - "There is no good for a man, except that he should eat and drink" Augustine would write: "what can he [Ecclesiates] be more credibly understood to say, than what belongs to the participation of this table, which the Mediator of the New Testament Himself, the Priest after the order of Melchizedek, furnishes with His own body and blood?" ${ }^{47}$ This predilection for metaphysical eucharistic interpretations of the scriptures and organisation of the Church would sustain the Eucharist until the Reformation. After the Reformation, the metaphysical status of the meal was debated and not always retained. Nevertheless, the metaphysical identity of the Eucharist has proven to be an unavoidable consideration in its history.

\footnotetext{
${ }^{45}$ Cf below, 71-74

${ }^{46}$ Cf below 110-123

${ }^{47}$ Augustine, City of God. 17.20. Translated by Marcus Dods. From Nicene and Post-Nicene Fathers, First Series, Vol. 2. Edited by Philip Schaff. Buffalo, NY: Christian Literature Publishing Co., 1887. Revised and edited for New Advent by Kevin Knight. http://www.newadvent.org/fathers/1201.htm.
} 
(ii) The Philosophical Emergence of the Issue

The second topic concerns the interconnections and divergences between ontology and the philosophy of relationship. The discussion of ontology and the identity of Being on the one hand and relationship - "otherwise than Being" - on the other, has gradually gained ground as the phenomenological movement has progressed throughout the twentieth century.

In 1974, the ability to discuss relationship and relationality was greatly enhanced by Levinas' work Otherwise Than Being or Beyond Essence. However, his achievement comes at the end of an arduous process of reflection. Regarding traditioning, the first crucial progress in distinguishing identity and relationship was achieved by Scheler (Formalism in Ethics and Non-Formal Ethics of Values, 1913). ${ }^{48}$ Then Buber (I and Thou, 1923 ${ }^{49}$ ) and Heidegger (Being and Time, 1927) added their indispensable contributions. Reflection on the contributions of these four philosophers absorbs the mind of this author. They are not only helpful contributors to a discussion of how the Eucharist signifies. The Eucharist also provides a valuable forum for the articulation of their insights.

In his Ethics, Scheler gave a brief description of phenomenology. There, he introduced an indispensable structural significance to the sense of "between" ("zwischen"). There are not only objective givens and subjective acts of intuition. There are also "the essential interconnections between essences of acts and of things." ${ }^{, 50}$ Scheler's German emphasises "zwischen Akt- und Sachwesenheiten" by putting those words in italics. ${ }^{51}$ He did not develop "zwischen" greatly but he referred to it. Since then "das Zwischen" has often been forgotten, yet it is indispensable to the sense of relationship. Heidegger explored the meaning of 'Being' and worked out the interconnections between identity

${ }^{48}$ Scheler, Max. Der Formalismus in der Ethik und die material Wertethik: Neuer Versuch der Grundlegung eines ethischen Personalismus. With an appendix by Maria Scheler. Edited by Manfred S. Frings. Bonn: Bouvier Verlag, 2000. This thesis also consults the translation by Fring and Funk. Scheler, Max. Formalism in Ethics and Non-Formal Ethics of Values: A New Attempt toward the Foundation of an Ethical Personalism. Translated by Manfred S. Frings and Roger L. Funk. Evanston: Northwestern University Press, 1973.

${ }^{49}$ Martin Buber's Ich und Du was first published in 1923 by Insel-Verlag, Leipzig. This thesis refers to Ich und Du, in Das Dialogische Prinzip, 9-136.

${ }^{50}$ Formalism, 72.

${ }^{51}$ Der Formalismus, 90. 
and relationship by basing both in the development of Being. ${ }^{52}$ Buber prioritized relationship and emphasised the sense of "the between"53. But neither Heidegger nor Buber clearly distinguished relationship or the between from Being. However, Levinas, through his rigorous argument against Heidegger's prioritizing of Being, advanced the idea of "proximite" 54 and thereby deepened the sense of "das Zwischen".

Between them the above philosophers explored the elements necessary for a phenomenology of tradition, "the one", "the other", and "the between". But none of them articulated a specific phenomenology of tradition. Therefore, they left an unanswered question: 'How does the hidden a priori issue - the distinction between identity and relationship - work in the manifest history of traditions?' The Eucharist is a traditional sign, therefore answering that question is crucial in developing a phenomenology of the Eucharist. Chapter 4 responds to that question and develops a phenomenology of tradition.

(iii) The Spiritual Emergence of the Issue

The third topic, that of mysticism or personal spirituality and the eucharist gets to the heart of this thesis. I, the author, am 64. For almost 33 years I have been a Roman Catholic priest in the Archdiocese of Wellington. A significant reason for this lifeoption traces back to a religious vision I had when I was seventeen. The vision still gives me fresh enlightenment about the path I have chosen. Therefore, I live out of a profoundly subjective motive for a public social commitment. This subjective motive could be described as the sense of being drawn by the loveableness I encountered in that vision. At the heart of both my subjective motivation and public commitment is the Eucharist. The same goes for my decision to write this thesis. The thesis has arisen out of a private initiative, but it is not simply a private confession. The topic of loveableness also arises in the discussions of the Trinity and the Eucharist according to St Thomas Aquinas, in chapter 3.

\footnotetext{
52، our aim in the following treatise is to work out the question of the meaning of Being and to do so concretely". Martin Heidegger, Being and Time, trans. Joan Stambaugh, 1996, 1.

53 “die Theophanie...nähert sich immer mehr der Sphäre zwischen den Wesen”, Buber, Ich und Du, in Das Dialogische Prinzip, 121.

${ }^{54}$ Levinas, Autrement qu'être, 129-155.
} 
Having made this point, it is also necessary to acknowledge that a dynamic of distinctions and interconnections between subjective motivation and public witness pervades all eucharistic spiritualities. In the contemporary environment those connections are particularly problematic. A comparison between the thirteenth century mystic Jacapone da Todi and the nineteenth century existentialist Soren Kierkegaard helps to introduce the point.

Jacapone da Todi was put in a cramped dungeon for five years for his opposition to Pope Boniface VIII. ${ }^{55}$ While there, he wrote a letter to the Pope showing that he did not retract his criticisms but he was a Christian in need of the sacraments, so he asked the Pope to come and say to him "I absolve you". ${ }^{56}$ After the death of Boniface, Jacapone was released from his incarceration and returned to monastic life. Three years after his restoration to the sacraments, his love for and through the Eucharist reached its apotheosis. Somewhat miraculously, yet according to his insistent prediction, his dear friend Giovanni de la Verna arrived to give him the sacraments, just before he died. ${ }^{57}$

Kierkegaard's spirituality of the Eucharist was also revolutionary but it differed markedly from Jacapone's. When Kierkegaard was sick, his pastor came to bring him the Eucharist; but he refused to receive it ${ }^{58}$. This was remarkable because the practice of Eucharistic devotion was integral to Kierkegaard's spirituality; he wrote thirteen devotional discourses on the sacrament. ${ }^{59}$ But, unlike Jacapone, Kierkegaard's protest against the unspiritual character of the Church of Denmark included his refusal to share in its sacraments. His refusal was both a protest and a plea for a Christian celebration of the eucharist. Therefore, the two devotees exhibit different convictions about the interconnections between spiritual discipleship and the traditioning of the sacraments. For Jacapone da Todi the holiness of the sacrament was unconditionally accessible through the authoritative tradition of the Church. For Kierkegaard it was inaccessible through a corrupt ecclesial authority.

\footnotetext{
${ }^{55}$ George T Peck, The Fool of God: Jacopone da Todi, University of Alabama Press, University, Alabama, 1980, 125.

${ }^{56}$ Fool of God, 129.

${ }^{57}$ Fool of God, 185-6.

${ }^{58}$ Bruce H. Kirmmse, ed. "Illness, Death and Burial." In Encounter with Kierkegaard: A Life as Seen by His Contemporaries, translated by Bruce H. Kirmmse and Virginia R. Laursen, 116-136. Princeton, NJ:Princeton University Press 1998, 125-126.

${ }^{59}$ Kierkegaard, Discourses at the Communion on Fridays, Trans. Sylvia Walsh, Indiana University Press, Bloomington, 2011, 37-48.
} 
However the matter is treated, a root problem remains. How do issues of objective identity and subjective relationality intersect in the celebration of the sacrament? Is there an unbridgeable gap between the relational subjective sense of the Eucharist and its traditional identity?

(b) How do Traditional Signs Signify? An Unresolved Problem in all Fields being Studied

A common denominator emerges in the areas that are being studied. A sense of tradition, capable of affirming the divergent elements of the traditional signs, is lacking in all the fields this study explores: in the history of the eucharist, in phenomenology and in the spirituality of the eucharist.

(i) The Loss of Relationship in the History of the Eucharist

In the era of the New Testament, Acts 6 shows the Christians wrestling with, but nevertheless agreeing, to worship as Jews and Greeks ${ }^{60}$. This was not for the sake of uniformity but for the sake of diversity. Hence, Greek deacons were elected to support the Greek members of the community. The first apostles were Jewish and, while delegating table ministries to the deacons, they maintained their ministries of the Word to both Jewish and Greek believers ${ }^{61}$. But this agreed diversity could not be sustained. This thesis attempts to explore the problem that the covenantal Judaism, which gave rise to the Eucharist, seems to have been lost through the history of the gentile Church. Acts 6 demonstrated the relational aspirations of a challenged community, willing to develop ways of traditioning that could serve and sustain the various traditions that made up the community. But history exhibits a loss of this acceptance of diversity.

(ii) The Loss of Relationship in the Literature of Phenomenology

In Being and Time, Heidegger radically criticized the influence of traditions on philosophy ${ }^{62}$. He was particularly opposed to the uncritiqued influence of metaphysical dogmas in the history of philosophy. In his effort to overcome the dogmatic practice of

\footnotetext{
${ }^{60}$ Acts $6: 1-7$

${ }^{61}$ Acts 6:2-3

${ }^{62}$ Heidegger, Sein und Zeit, 21-23.
} 
metaphysics he wrote "Being and Time". This was to give metaphysics a foundation in existential reflection rather than traditionally held dogmas. This did not mean the end of traditioning (Uberlieferung) ${ }^{63}$, rather a new need was recognised; the need to learn and hand on the 'how' of traditioning, rather than the 'what' of traditions. ${ }^{64}$ But this always involved engagement with past reflections on the meaning of Being; "to first of all reawaken an understanding that pertains to the meaning of this question". 65

Levinas sustained the phenomenological devotion to the 'how' rather than the 'what' of meaning but found this 'how' emerged through relationship and self-forgetfulness ${ }^{66}$, rather than through Being and anamnesis. This has had an even more dramatic impact on the sense of "tradition" than Heidegger's critique. For Heidegger, there was an everdeepening performance of the same basic thought, the unity of Being. Levinas, on the other hand, renounced this as a totalising commitment to Being. In his doctrine of the one-for-the-other, Levinas writes, "le rapport avec le non-moi précéde tout rapport du Moi avec lui-même." 67 Oneness only occurs, or "recurs", through a self lost to itself. Therefore, the identifiable and predictable recurrence of rememberable practices was radically problematized.

(iii) The Loss of Relationship in the Spirituality of the Eucharistic Disciple

A point that stands out in the previous discussion about Jacapone and Kierkegaard: the former treated the validity of the sacrament as a sign of traditionally communicated faith, while the latter treated it as a sign of individually performed faith. Here is something of a dilemma between traditionally and subjectively held faith. It suggests the question: what kind of faith is eucharistic faith? Is it faith in an intuitively given, or a traditionally given sign? Or some combination of both?

Furthermore, the conjunction of subjective inspiration and public practice is manifest in the history of the eucharist. From Paul to the present day, the issues of meaning and relationship that come to expression with regard to the eucharist are existentially important to many people. They not only result in people celebrating the eucharist. They

\footnotetext{
63 "sich vollziehende Destruktion des überlieferten Bestandes der antiken Ontologie" Sein und Zeit, 22.

64 "Nicht das sachhaltige Was der Gegenstände der philosophischen Forschung, sondern das Wie dieser." Sein und Zeit, 27.

65 "allererst wieder ein Verstandnis für den Sinn dieser Frage zu wecken.” Sein und Zeit, 1.

${ }^{66}$ Autrement qu, 272.

${ }^{67}$ Autrement qu, 189.
} 
also result in people leaving it. The many contemporary expressions of Christianity show that the eucharist involves extensive disagreement concerning beliefs that are both personal and institutional. These present challenging dynamics in the correlations of subjective preferences and social traditions.

(iv) The Eucharist and the Sense of Tradition

These very brief sketches of (1) the history of the eucharistic traditions, (2) the place of "tradition" in phenomenology, and, (3) the disconnections between subjective spirituality and the eucharistic tradition, exhibit the lack of an adequate sense of tradition in all three areas. The problem is that in the various areas, Jewish-Greek history of the eucharist, relational philosophy and either traditional or subjective spirituality, the established ways through which the traditions sustain their identities, do not correspond with the creative ways in which participants in the traditions have developed. In the early history of the tradition the gentile sense of identity failed to sustain the Jewish sense of relationship. In philosophy, the tradition of the identity of Being had supressed the sense of relationship that formed within it. In the spirituality of the eucharist, the traditional identity of the sign and the subjective motivation of the believer seem to have lost their connections; at least that is the development that Kierkegaard indicated.

The sense of traditional identity and the senses of subjectivity and relationship often seem to be out of step as participants in the traditions seek to progress their eucharistic spirituality. But these issues have ancient beginnings. Traditionally, the Greek tradition of Christianity has lost sight of Judaism. Traditionally, the philosophies of identity have inhibited the existential gift of relationships. Traditionally, the institution of the sacrament and the creativity of the disciple seem to have lost much of their correspondence. Does this sense of tradition obscure other senses that are more compatible with the passion to relate and create? Is tradition genuinely understood when it prioritises the maintenance of identity over the development of relationships?

Tradition is a ubiquitous element where the eucharist is concerned. But if a ubiquitous element in the history, intelligibility and spirituality of the eucharist is poorly understood, then surely the eucharist itself is poorly understood. Therefore, a fourth element, along with history, philosophy and spirituality needs to be explored in a 
phenomenological treatment of the Eucharist: tradition. It must be treated as a universal and distinctive contributor to the difference between identity and relationship. Reflection on the Eucharist demands reflection on tradition and traditioning. It is the way the eucharist signifies through time. This thesis seeks to respond to this lack in discussions about the Eucharist and about traditioning generally. Also, without a clear appreciation of traditioning it will be impossible to fully appreciate the Eucharist.

\section{Methodology}

(a) Phenomenology

The thesis moves from reflection on the emergent issue, - relationship and identity in the Eucharist - to the ultimate issue: the way relationship becomes distinguished from identity through the sense of loveableness. Phenomenology provides a way this movement can be understood, by reflecting on the contributions of Heidegger and Levinas.

Levinas taught that ethics and learning are motivated by "the infinite in the finite, more in the less" ${ }^{\prime 68}$. But he relied strongly on Heidegger's sense of the question as he learned to articulate this dynamic ${ }^{69}$. Heidegger description of the structure of enquiry also shapes this thesis.

In the "Introduction" to Being and Time, Heidegger analysed enquiry. He taught that a question concerns: (1) that which is asked about, ("das Gefragte"), (2) that which is investigated ("das Befragte") - to render accessible, the learnin soughtasked about ("das Befragte"), and, (3) to render accessible that which is to be learned ("das Erfragte") ${ }^{70}$ through the process of questioning ${ }^{71}$.

In applying these moments to his question about the meaning of 'Being' Heidegger identified: (1) "Being" as that which is asked about ("das Gefragte" 72). (2) "Dasein" ("the being of human be-ing) as that which is examined ("das Befragte" ${ }^{73}$ ) to render

\footnotetext{
${ }^{68}$ Levinas, Totalité et infini, 42.

${ }^{69}$ Levinas, Autrement qu'être ou au-delà de l'essence, 13.

${ }^{70}$ Heidegger, Sein und Zeit, 6-7.

${ }^{71}$ Heidegger, Sein und Zeit, 6-7.

${ }^{72}$ Sein und Zeit, 6.

${ }^{73}$ Sein und Zeit, 6.
} 
what is asked about more accessible. (3) "the meaning of 'Being"” ("das Erfragte" 74 )"as that which is to be learned through the process of questioning.

This was the project of "Being and Time", but the result differed from the project. Heidegger had structured Being and Time according to the threefold structure of the Question, but his achievement did not fulfil his plan. Heidegger planned a work of two massive parts. Part 1 included an account of how that which is asked about, das Gefragte, ("Being") may be explored. This was the "Introduction". ${ }^{75}$ It was followed by a very long treatment of das Befragte ("Dasein") ${ }^{76}$. Part 2 was to articulate das Erfragte ("the meaning of 'Being'). ${ }^{77}$

He never finished part 1, and never started part 2. When "Being and Time" was published it was composed of the "Introduction", and the first two of the three planned sections of part 1, concerning Dasein, das Befragte. But his incomplete project was helpful and necessary. In his later works, having opened up, what I am calling "the emergent issue" - the meaning of the 'being' of Da-sein - he was able to sustain his approaches to "the ultimate issue" - the meaning of 'Being' - (“das Erfragte") ${ }^{78}$.

It is thanks to Heidegger's example that this thesis (1) defers to an ultimate issue - the discovery of how the difference between identity and relationship signifies, - but (2) it does so by exploring an emergent or proximal issue; the Eucharistic expression of identity and difference. The quest is to achieve a better understanding, rather than solve an infinite mystery. Therefore, modelled on Heidegger's achievement, this thesis is determined to help unfold an answer to the general question 'how does relationship differ from identity?' As this issue emerges through the Eucharist, the thesis approaches its ultimate sense without necessarily grasping it.

In reflecting on these methods of approach and the gift of ultimate meaning, there is something astonishing about the bonds between approach and ultimacy in Thomas Aquinas' late treatments of the Eucharist and the Trinity. In his late writings on the

\footnotetext{
${ }^{74}$ Sein und Zeit, 7.

${ }^{75}$ Sein und Zeit, 2-40.

${ }^{76}$ Sein und Zeit, 41-437.

${ }^{77}$ Heidegger, Sein und Zeit, 40.

${ }^{78}$ For an instructive study of Heidegger's philosophy after Being and Time cf Derrida, Jacques, Of Spirit: Heidegger and the Question, trans. Geoffery Bennington and Rachel Bowlby, University of Chicago Press, Chicago, 1989.
} 
Trinity he articulates an encounter with loveableness. "The good is loveable to itself.,"79 This proposition provides the most formative axiom for the thesis. Loveableness "moves the lover to love the beloved" 80 . There are correlations here with Levinas' doctrine of "transcendence" and "obsession". According to him subjectivity is structured as a dynamic obsession with the transcendence of the other ${ }^{81}$. It is these correlations which provide the prospect of an Aquinas/Levinas synthesis in Chapter 3 of this thesis

\section{(b) Reflective Approaches to Scripture and other Traditional Documents}

The thesis is reflective; it reflects on both the evidence before it and the approaches to that evidence. Therefore, the evidence for the eucharist is not only found in its documentation in the scriptures, along with traditional and contemporary texts. It is also found in the ways those texts, along with the Eucharist itself, are approached. Reflection on the approach is treated as a first premise for phenomenology.

The oft-forgotten question of approach is the first moment of genuine evidence concerning the significance of a sign. Here the phenomenology of the eucharist is explored because both the eucharist and phenomenology are important to this author. Their importance forms the approach and the ways in which they are important to me will become clearer as the study progresses. But the question of approach is mentioned here because it belongs to a methodological starting point more far reaching than my autobiography. The question of approach and its neglect also concerns approaches made in other eras. For example, it will be applied to Cyprian's letter to Caecillius of Bilthra in $253 \mathrm{CE}^{82}$. How did he approach the last supper texts? Not only, what did he say about them? But, why did he say that? What was his perspective on scripture and the Eucharist that he should write about it in that way? For when Cyprian was writing about the significance of the Eucharist in the biblical era he was expressing the significance of the Eucharist for him in his era.

\footnotetext{
${ }^{79}$ Bonum.....se amabile est", Aquinas, Compendium Theologicae 1.45, in Opera Omnia, Corpus Thomisticum, http://www.corpusthomisticum.org/ott101.html.

80 "Movetur .... amans ab amato". Compendium Theologicae 1.45, in Opera Omnia, Corpus

Thomisticum, http://www.corpusthomisticum.org/ott101.html.

${ }^{81}$ Levinas, Autrement qu'être, 137-142.

${ }^{82}$ Cyprian, "Epistle LXII" (English) and "Epistula LXIII" (Latin). Note different numbering in the English (ANF) and Latin (CSCO) editions of Cyprian's writings due to Ad Donatum being included as Epistle $I$ in the latter.
} 
It will be argued that Cyprian, like many others, was unintentionally redefining the earlier significance of the eucharist, according to his sense of its significance in his era. The idea that the Eucharist went through the many developmental phases that it has, was to him, unthinkable. He was a disciple of Jesus living in the classical world. To the point of his martyrdom! He was committed to sustaining the practice he believed he had inherited "from the Lord" ${ }^{83}$. This was his sense of responsibility, his sense of traditioning.

The point of difference between the account of the eucharist given in this thesis and the account given by Cyprian is therefore twofold. Firstly, this thesis is not classical. It does not arise in an era which is ignorant of how traditions change as they process from one generation to the next. Secondly, it is not the work of a martyr. It cannot even remotely hint at the passion that resulted in his redefining the eucharist for the next 1800 years. But this author can learn from the approach of a Cyprian, a Clement, an Edith Stein; authors whose intellection of the sign was not formed by their efforts to command it but to surrender to it.

An effort to find the text's Sitz-im-Leben applies also to scripture. The New Testament texts respond to an environment in which the eucharist already existed as a traditional sign. Therefore, they also witness to an approach and the history of the sign can be learned from those texts. The understanding of scriptures can also be deepened as the formative relationship between the sacrament and the scriptures becomes more evident. The same can be said about other contemporary texts such as the Didache. ${ }^{84}$

Not that the Didache and the scriptures describe the Eucharist in the same way. The scriptural texts bind the eucharist to the death and resurrection of Jesus ${ }^{85}$, the Didache does not. ${ }^{86}$ The last supper texts offer the definitive sense of the eucharist, in perpetuity, because they demonstrate the bond between the eucharist and the Easter sacrifice. This does not mean the Didache was not a eucharist of the early Church. It refers to the liturgical meal as "the eucharist" and is more authorized to say what a eucharist of that era was than an observer situated in the twenty-first century. On the other hand, it differs from the New Testament accounts of the eucharist in terms of the historical

\footnotetext{
${ }^{83} 1$ Cor 11:23 and Epistula LXIII, 2.

${ }^{84}$ Teaching of the Twelve Apostles: Didache, from The Apostolic Fathers, ed. by Kirsopp Lake, Loeb Classical Library, William Heinemann Ltd, London, 1912, 9 and 10.

${ }^{85}$ Cf 1 Cor 11:23.

${ }^{86}$ See below, 158 .
} 
trajectory it gives to the meal. Because the element of trajectory, or projective traditioning is so strong in the traditioning of the eucharist, the scriptural, liturgical and traditional theological texts will be explored with this in mind.

(c) The Relationship to other Phenomenologies of the Eucharist

This thesis is on traditioning. To this author's knowledge traditioning is a new topic in phenomenology and it has become accessible thanks to Levinas. Studying the Eucharist is undertaken, because traditioning is at the heart of the Eucharist. Therefore it relies on the Eucharist as a sign of traditioning, and on Levinas as the philosopher who has made a description of traditioning possible. In this respect it is not an Husserlian phenomenology of the Eucharist, as with Sokolowski ${ }^{87}$, nor is it a conjunction of Rahnerian onto-theology and Levinasian Ethics, as with Purcell ${ }^{88}$. It is not influenced by Marion's phenomenology of the Eucharist as Gift ${ }^{89}$ and, for all its compatibility with Wallenfang's "trilectic" appreciation of the Eucharist, ${ }^{90}$ the body of the thesis was completed in the year Wallenfang's "Dialectical Anatomy of the Eucharist: an Étude in Phenomenology" was published. In short, the thesis derives from none of the above, and while it shares the élan of their works, it is not materially based in their works. It is based in Levinas and the history of the Eucharist. But it was written with a view to providing original material for the dialogue between the sense of a Eucharist based in traditioning, and the work of the authors mentioned above. Some comments on the pertinence of those works to this thesis follows.

In Eucharistic Presence: A Study in the Theology of Disclosure, Sokolowski begins by describing the Eucharist as a celebration of Salvation in Christ. "It looks backward in time to the last supper and the death and resurrection of the Lord, and, more remotely, to the Passover and the Exodus. It also looks forward to the eternal life that was won for us by Christ on the cross:...the promise of future glory is given to us." ${ }^{91} \mathrm{He}$ then

\footnotetext{
${ }^{87}$ Sokolowski, Robert, Eucharistic Presence: A Study in the Theology of Disclosure, Catholic University of America Press, Washington D.C. 1994.

${ }^{88}$ Michael Purcell, Mystery and Method the Other in Rahner and Levinas, Marquette University Press, Milwaukee, 1998.

${ }^{89}$ Jean-Luc Marion, God without Being: hors-texte, Translated by Thomas A. Carlson and with a foreword by David Tracy. University of Chicago Press, Chicago, 2012.

${ }^{90}$ Wallenfang, Donald. Dialectical Anatomy of the Eucharist: an Étude in Phenomenology. Jean-Luc Marion, Introduction. Wipf and Stock Publishers, Eugene OR, 2017.

${ }^{91}$ Eucharistic Presence, 3.
} 
discusses approaches of interpretative theology and introduces the term "theology of disclosure" to describe "how the Christian things taught by the Church and studied by speculative theology come to light". 92 "If speculative theology... were to be considered 'ontological', the theology of disclosure could be called 'phenomenological'."93 The theology of disclosure "works against deeply ingrained prejudices that distort both our religious and cultural understanding"94

The phenomenology that Sokolowski employs is resolutely Husserlian. ${ }^{95}$ He sustains Husserl's practice of distinguishing the ways in which givens are rendered meaningful. This includes the distinction between appearances and identity ${ }^{96}$. His Husserlian understanding of the disclosure of identities through phenomena is very profound and engages with the meaning of the person ${ }^{97}$ and the many depths at which appearances signify. ${ }^{98}$ This leads to a profoundly reflective approach to theology which resonates with patristic inspiration and brings it into the present day. The "theology of disclosure" is a valuable kind of theology. On the other hand, Sokolowski's work is not Levinasian, it does not explore the phenomenology of relationship and explores the phenomenological givens of the tradition rather than how traditioning comes about. Therefore it explores the Eucharist differently to this thesis.

Differing from Sokolowski, Purcell, in Mystery and Method: the Other in Rahner and Levinas bases his phenomenology in Levinas not Husserl. He describes a corresponding treatment of subjectivity in Rahner's and Levinas' movements from the finite to the infinite. But this is difficult, "for both Rahner and Levinas, the subject is a transcendence towards the absolute. For Rahner, this is absolute Being... for Levinas, the absolute lies beyond Being and its categories and is encountered in the ethical relationship with the Other." 99 To resolve this difficulty he writes, "we want to argue that it is not so much a question of the otherwise than being but of being otherwise, and particularly of being otherwise than Levinas' comprehension of being. Levinas, of course, disavows this notion, saying that " transcendence is passing over to being's other, otherwise than being. Not to be otherwise, but otherwise than being. And not to

\footnotetext{
${ }^{92}$ Eucharistic Presence, 7.

${ }^{93}$ Eucharistic Presence, 8.

${ }^{94}$ Eucharistic Presence, 9.

${ }^{95}$ Eucharistic Presence, 9-10.

${ }^{96}$ Eucharistic Presence, 25.

${ }^{97}$ Eucharistic Presence, 120.

${ }^{98}$ Eucharistic Presence, 200-202.

${ }^{99}$ Mystery and Method, 247.
} 
not-be..." (Levinas, 1981, 3, italics as in source)." ${ }^{100}$ Purcell criticizes Levinas saying, "before one can consent to this "otherwise than being," one needs to be clear about the "being" which one is called to be "otherwise than"."101 But his response is simply a reversion to ontology. However clear one may be about "being" it is still necessary to address the question of being's other as a distinct matter. Prioritising clarity about "being" maintains the identified being of the tradition and does not allow the relationality of traditioning to radically affect the meaning of the traditioned sign. Conjoining "being" and "otherwise" in the one form of "being otherwise" suppresses the exteriority of the relational signifier, the face of the other. How, without the exteriority of being's other, is it possible for a being to move from being-for-itself to "being otherwise"? A fortiori, how, without the affirmation of exteriority, is it possible for a tradition to be moved from traditioning for-itself to traditioning for the others?

But this criticism of Purcell is made reluctantly. His profound scholarship and concern for the other is palpable. This is one of the reasons he does not figure strongly in this text. It requires at least one chapter to do him justice and I would rather be his protagonist than his antagonist. These observations are made simply to show that this thesis is not the same as Purcell's.

In "An Agape of Eating: The Eucharist as Substitution (Levinas)"102 Purcell celebrates Levinas' articulation of ethics as substitution. "Substitution rather than transubstantiation expresses the meaning of the Eucharist". ${ }^{103}$ This thesis is similar to Purcell's by prioritising substitution. But it also argues the need for the term "transubstantiation". It maintains the term "transubstantiation" to describe an alteration in the referential simplicity of the sign. It is no longer both bread (or wine) and sign, it is simply sign. Hence it is transubstantiated, a pure, relational signification of the one for the other. The term refers to the absolute alteration of a sign that loses its ontological identity and simply signifies an altered - relational - identity.

As close as this thesis is to Purcell's aspirations it seeks to establish an element in the processes of traditioning that signifies otherwise-than-being. This matter is outside the aims of Purcell's very important contribution. In Mystery and Method Purcell, tends to

\footnotetext{
${ }^{100}$ Mystery and Method, 297.

${ }^{101}$ Mystery and Method, 297.

102 Purcell, Michael. "An Agape of Eating: The Eucharist as Substitution (Levinas).” Bijdragen 57 (1996) 318-36.

${ }^{103}$ An Agape of Eating, 318.
} 
bypass Levinas' radical sense of "being's other". In Agape of Eating, he does not engage with the traditional significance of "transubstantiation". Thanks to Levinas, this thesis is concerned with the traditioning of the sense of the one-for-the-other in Eucharistic transubstantiation. According to this thesis, "transubstantiation" describes the Eucharist as a traditioned sign of absolute deference to the infinite alterity of the other.

Wallenfang's "Dialectical Anatomy of the Eucharist, An Étude in Phenomenology", could not provide the basis for this thesis because its publication was too recent. Nevertheless, of the eucharistic phenomenologies considered here it is the closest to this thesis. In particular it raises issues of temporality that are intrinsic to a Levinasian analysis.

Concluding his Introduction to Wallenfang's book, Marion praises Wallenfang for surpassing his own treatment of Eucharistic phenomenality ${ }^{104}$. He also praises the sense of temporality the book provides. "The gift thus endlessly repeated, like forgiveness regiven seventy times seven times, can be conceived only in eschatological time, time given on the basis of the end, the time of the fidelity of the gift given from eternity, before the beginning of the gift. Perhaps it is towards this that the magnificent study that follows will lead the reader, sooner or later." 105

This applause for Wallenfang's treatment of "time given on the basis of the end" resonates strongly with the idea of "predilection" developed in the following thesis. This thesis also attempts to think rigorously, the phenomenality of the sacrament. Combining these elements of temporality and phenomenality, it is probably fair to say that both Wallenfang and this author provide the opportunity for resaying the mediaeval Latin term "transubstantiation" - sourced through Aristotle's "substance" - through a hitherto unsaid phenomenological term "transtemporalization" - sourced through Heidegger's "temporality". Though there has been no time to respond to Wallenfang in the main body of the text, the following reflection centers on the treatment of temporality in Anatomy of the Eucharist.

Crucial to Wallenfang's sense of temporality is the term "trilectic". Trilectic arises out of Wallenfangs point of departure which is "dialectic". "Our point of departure...will be

\footnotetext{
${ }^{104}$ Dialectical Anatomy, xxi
}

${ }^{105}$ Dialectical Anatomy, xxiii. 
the manifestation $\leftrightarrow$ proclamation dialectic."106. "We can identify plainly a dialectical relationship between that which originally manifests itself $\ldots$ and the various testimonies that proclaim what manifests itself." ${ }^{107}$ Marion is the most important voice for manifestation, Ricouer and Levinas for proclamation. Levinas is also the most important voice for testimony.

Levinasian testimony, or witness, produces "trilectic, namely the trilectic of testimony"108. Testimony, responds to "the call of the other" ${ }^{\prime 109}$. The trilectic response to the call of the other, and among each other, produces an ongoing conversation concerning the meanings that arise through the dialectic of manifestation and proclamation. This conversational responsibility moves the community of witnesses to unite in a way that respects their diversity. "We might enquire, moreover, whether the call of the other is not only the beginning of meaning but also its terminus". ${ }^{110}$

Although he does not use the term "traditioning", Wallenfang's sense of "trilectic" which deepens the "unity-in-diversity dialectic"111 resonates closely with what this thesis means by "traditioning". Wallenfang does not make this observation but the sense of beginning and terminus that trilectic evokes offers a syntagmatic or directional axis. Such an axis deepens the paradigmatic or horizontal axis of "unity-in-diversity dialectic". It is also valuable to note that the trilectic or syntagmatic axis (between beginning and terminus) provides a diachronic conjunction among the bearers of the tradition while the dialectic or paradigmatic axis (of manifestation and/or proclamation) provides a synchronic conjunction of the bearers of the tradition. This thesis emphasises the diachronic axis of traditioning. On the other hand, Wallenfang thinks traditioning, or "trilectic", in a way that gives similar emphasis to each axis.

Had Wallenfang's comprehensive embrace of Marion, Ricouer and Levinas been published before the completion of the arguments in this thesis, they would not have changed. On the other hand, the explorations of syntagmatic diachrony and paradigmatic synchrony, which his work has stimulated, will, I hope, open up valuable future discussions on the relationships between beginnings and ends. This points to the main reason the argument of this thesis would not be changed in its actual identity but

\footnotetext{
${ }^{106}$ Dialectical Anatomy, 26.

${ }^{107}$ Dialectical Anatomy, 43.

${ }^{108}$ Dialectical Anatomy, 43.

${ }^{109}$ Dialectical Anatomy, 46.

${ }^{110}$ Dialectical Anatomy, 47.

${ }^{111}$ Dialectical Anatomy, 43
} 
would be changed in its relational potential, thanks to Wallenfang's "phenomenological étude". The two works are complementary. Wallenfang emphasises an infinite gift of identity, I emphasise an infinite sense of relationality. This difference and compatibility is evident through the concluding paragraphs of Wallenfang's work.

Wallenfang speaks of "beginning and end...A $\Omega$ " as "“always-already, notyet"/“historical-proleptic, eschatological' an identity of depth"112. Replacing Wallenfang's "identity" with "relationality" I would write of "beginning and end...A$\Omega$ " as "infinite and irresistible loveableness, always-already (through pre-dilection) relationality of depth". The same strategy can be applied later in the same passage. Wallenfang writes: "Depth is not generated by self-subsisting presence or by "more of the same," but only by the sustained trialogue of M [manifestation], P [proclamation] and $\mathrm{T}$ [testimony]. Depth itself is a generative form that in turn engenders and promotes the fecundity of the trilectic." 113 In response, is this thesis offers the thought, 'depth is not generated by self-subsisting presence or by "more of the same," but only by the infinite loveableness of the other. Depth itself is a gift coming from the infinitely obsessing difference of the other that in turn engenders and promotes the fecundity of trilectic or traditioning"”. It seems to me that by "identity of depth" Wallenfang offers a sense of the deep unity that sustains an infinite paradigmatic diversity. According to this author, relationality of depth offers the diachronic character of a radical syntagmatic difference, proximité. Therefore, the distinct emphases on identity and relationship seem to render the works complementary; though not without points of critique emerging between them.

(d) Further Reflections on the Methodology of This Thesis

(i) Marion and Levinas

Marion is immensely important in the history of phenomenological method, and - par excellence - in relation to the Eucharist. Therefore it seems fitting to discuss his treatment of the Eucharist in a way which relates to the methodological priorities through which this thesis proceeds. In particular the discussion will compare Levinasian method with Marion's and show the basis for preferring Levinasian to Marionian

\footnotetext{
${ }^{112}$ Dialectical Anatomy, 251

113 Dialectical Anatomy, 252.
} 
method: i.e. that Levinas has found a way of distinguishing the non-phenomenal sense of relationship from the phenomenal sense of identity.

Marion contrasts with Purcell. In "God Without Being" he insists on the term “transubstantiation", because it articulates the Eucharist's immediate givenness, outside consciousness, conceptualization and textualization. "Now, the theology of transubstantiation alone, offers the possibility of distance, since it strictly separates my consciousness from Him who summons it" ${ }^{114}$. To understand this point it is necessary to understand the saturated and saturating significance of Christ. "Christ says himself the Word." "115 This is love saying itself. "The Son took on the body of humanity, only in order to play, humanly, the trinitarian game of love."116 "That he says himself means that he abolishes the gap between the speaker...who states and the sign (speech or text)." teaching about the pure simplicity of the word and the absolute immediacy of the gift of love. When applied to the Eucharist, the purely self-saying word cannot be bread and/or wine because, if it were, it would not be the self-saying Word, i.e. the word that says itself purely for the other. It would be a word that says "bread" and "wine", and thereby indicate that the bread and wine still say themselves and have not been transformed by the otherness that the Word says. The gift of love in the Eucharist is absolutely saturating, it saturates saturation. It is because the persons of the Trinity utterly saturate the givenness of the Eucharist with love, "continue to give themselves without return...that the body and blood persist in an otherness that goes as far as the bread and wine" 119 .

There is no question of the transforming depth of Marion's work, but he does not provide a way of distinguishing relationality and identity in the processes of traditioning. His radically new phenomenology of the Gift, describes both "word" and "love". Therefore it indicates a difference between identity ("word") and relationship ("love"), but it requires rather than offers a basis for that distinction. Instead, both are

\footnotetext{
${ }^{115}$ God without Being, 140.

${ }^{116}$ God without Being, 177.

${ }^{117}$ God without Being, 140.

${ }^{118}$ God without Being, 140.

${ }^{119}$ God without Being, 177.

${ }^{119}$ God without Being, 177.
} 
described through the sense of "Gift", "principe de tous les principes". ${ }^{20}$ Levinas, on the other hand, confronts the very idea of a principle and destabilises the sense of principle through his treatment of "trace". ${ }^{121}$ A trace is a sign of an absence and relationship to a missing identity rather than a presence. This leads to a distinguishing of identity and relationship.

Levinas binds the trace to proximity and writes that "anarchically", thanks to the "trace", "la proximité est ainsi une relation avec une singularité sans la médiation d'aucun principe, d'aucune idealite." "122 Therefore, rather than argue that revelation arises as the pure phenomenality of the given - a concept that does not fully examine the temporal (diachronic) character of the given - he describes revelation in terms of diachrony itself. Diachrony, the most radical and athematic fact (fait) or undoing (defait $)^{123}$ of phenomenality, involves departure and the non-phenomenal significance of the other, "the face of the other". "Le visage de l'autre dans la proximité - plus que representation - est trace irreprésentable, façon de l'Infini"'. ${ }^{124}$ Non-phenomenality: this "way of the Infinite" - in the approaching face of the other - arrives through "the trace of a departure" ${ }^{\not 25}$. The simplest way to grasp this concept is through considering the unfinishable obsessing character of the death of another. With this in mind, the nonphenomenal sense and infinite depth of relationship can be read in the following sentence; it speaks of "the trace of a departure". "It is because the trace of the Infinite is inscribed or written out (s'inscrit ou s'écrit) in the approach - trace of a departure... that there is forsakenness of the other, obsession by him, responsibility and Self." 126

Through this perspicacious appreciation of phenomena Levinas further reduces Marion's phenomenal sense of "étant donné" to the non-phenomenal sense of passivité donné: passivity of departure in the relational call of the trace, rather than passivity of being in the evidence of the gift. The other's departure is already evident in the mortal temporalizing of the approach. The trace, (the sign of passing away) is the gift of the non-phenomenal that signifies through the diachronic witness of the face. But why

\footnotetext{
${ }^{120}$ Jean-Luc Marion, Étant Donné: essai d'une phénoménologie de la donation, Presses universitaires de France, Paris, 2005, 257.

${ }^{121}$ Autrement qu', 158.

${ }^{122}$ Autrement qu', 158.

${ }^{123}$ Transcendance "defaire sa facticité". Autrement qu', 13.

${ }^{124}$ Autrement qu'184.

${ }^{125}$ Autrement qu', 184.

126 “'C'est parce que dans l'approche s'inscrit ou s' c'écrit la trace de l'Infini - trace d'un depart, ... qu il y’a délaisement d'autrui, obsession par lui, responsabilité et Soi." Autrement qu', 184.
} 
should the other's departure matter? It is because the other brings the immediate, nonphenomenal gift of relationship that, prior to all choice, subjectivity is affected by relationship. Subjectivity is not ontologically passive but relationally passive in the approach of the other. Therefore, the relational gift of the diachronic signifies ethically. The value of the other goes beyond the moment of the departure, or rather the moment of the departure is infinitely diachronic, infinitely relational, "love is strong as death" 127. The passing of time which says the interminable departure of the other signifies and obsesses. It articulates the unfinishable value of the infinite. The temporalising of the face expresses the infinite and invincible loveableness of the other.

Comparing Marion's phenomenology of the Gift, with Levinas' phenomenology of the face it becomes evident that through Levinas' appreciation of the traces of time, he explores characteristics of phenomena that Marion neglects. Through the concepts diachrony and the trace he articulates the sense that non-phenomenality is at the basis of all phenomenality and that this non-phenomenality obsesses with infinite relationality. Such passivity is a relational passivity, obsession with the departure, or infinite relationality of the other.

In terms of the task of this thesis; although Marion's phenomenology of the Gift, requires a basis for the distinction between relationship and identity it lacks it The case is quite different with Levinas. "The phenomenology of the face" immediately gives a distinction between identity and relationship. Identity figures in the face of the other, and relationship expresses itself between the other who approaches and the one who is approached. That relationality between the other who approaches and the one who is approached is explained on the basis of diachrony. Diachrony reveals the crisis of departure and therefore the awakening to responsibility of the-one-for-the-other. This relational temporalization provides the basis for the sense of traditioning that pervades the following studies of relationship and identity in the Eucharist.

(ii) Levinas and the methodology of this thesis.

In Autrement qu'être Levinas wrote, “Que l'emphase de l'ouverture soit la responsabilité pour l'autre, jusqu'a substitution - le pour l'autre du dévoilement, de monstration, virant en pour l'autre de la responsabilité - c'est en somme, la these du

${ }^{127}$ Song of Songs 8:6 
présent ouvrage." But the method of this thesis is also to seek out the openness for the other that hides among openness of identities and to do so through an emphasis that yields the sense of relationship. Much of this has already been articulated in the preceding discussion on Marion and Levinas. However a few more points may be added.

Firstly, it is also necessary to show how the term "traditioning" arises through Levinasian thought. Secondly, it is necessary to show the way this thesis, in the tradition of Levinas, adheres to the analysis of phenomena. Finally, the thesis describes the Levinasian reduction to "substitution" as a way of distinguishing the related to from the relator and then redefining the relator as the related to of the related to. To justify this approach it is necessary to show how a Levinasian approach guides the thesis to an argument through which the first becomes last; ie the relator becomes the related to of the related to (like the Good Samaritan - a neighbour to the neighbour) ${ }^{128}$.

Firstly, "traditioning" emerges in this thesis, when Levinas' reflections on diachrony are sustained to involve not only the one for the other, but also the one and the other for the third. "Le tiers est autre que le prochain, mais aussi un autre prochain,.... Paix, paix au prochain et au lointain", nous comprenons maintenant l'acuité de cette apparente rhétorique" ${ }^{, 129}$. This point can only be mooted here, but it cannot be argued on the necessary premises until they are established in the course of the argument.

Secondly, the most basic thought of this thesis is that it is phenomenological. Therefore, it seeks the temporal sense of phenomena. But as has already been described in the treatment of Levinas and Marion, the temporal sense of phenomena is insuperably diachronic and de-thematisation is a product of diachrony. Diachrony, involves passing away or passing on. Therefore, th thesis explores the diachronic flow of phenomena. This diachronic flow becomes traditioning. It is on the basis of its diachronic temporalizing through the Eucharist that traditioning is explored in this thesis. Professor Paul Morris has given me the necessary guidance to develop a phenomenological practice that adheres to the temporality of phenomena and allows its relational sense to reveal itself. Professor Paul Morris has given me the necessary guidance to develop a phenomenological practice that adheres to the temporality of phenomena and allows its relational sense to reveal itself. Chapter 1 exhibits this commitment to the givens of

\footnotetext{
${ }^{128}$ Luke 10:29 and 36

${ }^{129}$ Autrement que, 245.
} 
temporal relationality. In Part B of that chapter, the diachronic flow of a liturgy the author recently celebrated is explored with a sometimes pedestrian commitment to detail. ${ }^{130}$ In Part $\mathrm{C}$ of the same chapter, the temporal dynamics of that celebration are analysed. ${ }^{131}$ The temporalisation of the ancient Eucharist in its first 5 decades is then studied to ascertain how it signified through its historical developments. ${ }^{132}$ In this process it becomes evident that the ancient Christian sense of "ha yahid", interpreted as 'the loveable one', signified at the heart of the first Eucharists. The narrative structure of Psalm 22 is studied as a witness to how "yahid" and therefore the Eucharist temporalized. ${ }^{133}$ Throughout the remainder of the thesis the relational and diachronic structure of the Eucharist is examined in different forums. The bond through which the relator becomes the related to of the related to, may be understood through Levinas' doctrine of "substitution". In the preliminary note before the text proper of Otherwise Than Being or Beyond Essence Levinas Levinas flags the importance of "substitution" for his text. There he declares the book has been "bâti autour du chapitre IV qui en fut la pièce centrale"134. That chapter is entitled "Substitution". ${ }^{135}$ At the center of that Chapter arrives the core section also entitled "Substitution". ${ }^{136}$ At the end of that section the text reaches a kind of target that has been set up in the opening argument. There he writes of "expiation"137.

The significance of the word "expiation", and its vulnerability to misunderstanding, has been signalled early in the book. "Is it necessary to go to the point of giving a name to this relation of signification grasped as subjectivity? Is it necessary to pronounce the word expiation and to think the subjectivity of the subject, the otherwise than being as expiation? That would be, perhaps, audacious and premature." ${ }^{138}$ But he holds to this audacity. Shortly after he refers again to "expiation" as the extreme expression of substitution. "Voilà, pousée à bout, la sensibilité....Substitution à l'autre - l'un à la place de l'autre - expiation." ${ }^{139}$ Finally, at the end of the section on Substitution, in the chapter "Substitution", Levinas responds to the question "is it necessary to speak of

\footnotetext{
${ }^{130}$ Cf below, 39-46.

${ }^{131}$ below, 46-55.

132 below, 55-71.

${ }^{133}$ below, 71-73

${ }_{134}$ Autrement que, 10.

135 Autrement que, 156-205.

${ }_{136}$ Autrement que, 179-188.

${ }^{137}$ Autrement que, 187-188.

${ }_{138}$ Autrement que, 30.

${ }^{139}$ Autrement que, 31.
} 
substitution" 140 and writes, "il faut parler ici d'expiation, comme réunissant identité et alterité." $^{141}$

These quotations are enough to indicate the sense of the self in and through substitution. It is not a self-actualising gift of the one-for-the-other. Expiation is involuntary. In expiation, anterior to the initiative of the will, it is "as if the unity and unicity of the ego were already the self taking on the gravity of the other." 142 In this thesis the phrase "the related to of the related to" is used to express thatsense of substitution. The self takes on the other's burden. The other's burden is a burden of identity a burden of the identity of being related to, infinitely passive, yet unable to relate, lacking the freedom of an agent. But taking on the identity of the related to, the self binds the gift of relationship to the other's passive identity and sense of self as related to. The related to of the related to, opens up the sense of relationship for the other. This sustaining of relationship in the midst of identities is expiation, "the reuniting of identity and alterity."

(iii) through Levinas philosophy has reached the sense of relational saying that pervades this thesis.

In the history of philosophy, relationality has been suppressed. Rosenzweig, whose Stern der Erlösung, was present in Totality and Infinity "too often to be cited"143, wrote "The cosmos, from Parmenides to Hegel, had been securus adversus deos. It was so, because the cosmos itself included the absolute."144 Rosenzweig's exposure of ontology's comprehension of relationship by the identity of the Being of the world, involves particular problems for this thesis.It has to deal with the fact that the Eucharistic tradition is profoundly ontological. However thanks to the tradition of Rosenzweig, Buber and Levinas the thesis involves a methodology that overcomes that ontological prowess.

The history of philosophy parallels the development of a pregnancy. The mother is the relator, the baby is the related to. Initially the relator is known and knows herself, but the related to is unknown. Then the mother discovers she is pregnant. The relator remains known while the related to also becomes known but remains hidden. Then, the

\footnotetext{
${ }^{140}$ Autrement que, 30.

${ }^{141}$ Autrement que, 187.

${ }^{142}$ Autrement que, 187.

143 “L'opposition à l'ideé de totalité, nous a frappe dans le Stern der Erlösung de Franz Rosenzweig, trop souvent present dans ce livre pour être cite." Levinas, Totalité et infini: Essai sur l'extériorité, 14 144 "Der Kosmos von Parmenides bis Hegel war securus adversus deos gewesen. Er war es, weil selber das Absolute einschloss". Franz Rosenzweig, Stern der Erlösung, 17.
} 
time of wonder reaches its climax and the baby is born. Then the related to is revealed. The baby remains related to, but the mother, looking into the baby's eyes, finds, even more powerfully than before that she is not the agent-relator. She is the related to of the related to, patient, responsible, for the other. Then the discovery of being related to liberates the horizon of relationship or relationality. The entire exercise of this thesis is to articulate the liberating horizon of relationship; infinition through relationship.

The significance of being the related to of the related to characterizes the Wisdom of Solomon. ${ }^{145}$. Following a wisdom aligned with Aristotle, one might try to find an inherited characteristic in the baby to determine whose baby Solomon has before him. But Solomon does not discern the mother by discovering the baby's passivity to the mother's gift of relationship. He discerns the mother by discovering the mother's passivity to the baby.

This same exposure of passive yet moved relationality is evident in Thomas Aquinas' last work on the Trinity. ${ }^{146}$ Until the Compendium of Theology the idea that the Father is passive to the relationality of the other persons of the Trinity was completely unknown. Yet Thomas articulated a sense of the Trinity in which the Father, relator, is discerned to be the related to of the related to. Yes "the mover contacts that which is moved" ${ }^{147}$ But the moved is the agent-lover, and the mover is the patient-beloved! ${ }^{148}$. This relational hierarchy of movement, in which the passive beloved is the mover and the agent lover is the moved - or in which the final cause is the mover and the originary cause is the moved - completely reverses the ontological hierarchy of movement. According to ontology, the origin is the mover and the end is the change that the origin produces. But this is not ontology, this is relationality.

The thesis therefore sets out to distinguish the passive sense of the related to from the active sense of the relator. To do this it invokes the sense of loveableness as the relationally causal element by which the beloved moves the lover. Attending to this matter of relational causality this thesis aligns itself to Levinas' campaign for a kind of philosophical discourse which was not given a place on Porphry's tree. Yet it's necessity had been exposed as long ago as Plato. "Since the Republic there would be the

\footnotetext{
1451 Kings 3:16-28.

${ }^{146}$ S. Thomae Aquino Opera Omnia. Corpus Thomisticum. Compiled by Enrique Alarcón. Pamplona: Universitas Studiorum Navarrensis, 2000-, Compendium Theologiae, 1:45. http://www.corpusthomisticum.org.

147 "movens contingat id quod movetur", Thomas Aquinas, Compendium Theologiae 1:45.

148 "Movetur enim quodammodo amans ab amato", Compendium Theologiae 1:45.
} 
question of the beyond essence". ${ }^{149}$ Thomas' last writing on the Trinity also, exposed the need for a genre of philosophical reflection which is not determined by ontology. These points obtain in spite of Plato's and Thomas' allegiance to ontology. They concern the goodness of relationship and the relationality of the good.

One point in particular binds the reflections on relationality in Thomas and reflections on relationality in Levinas. Discovering the obsessive passivity of the subject to the vulnerable alterity of the other, Levinas articulated the idea of a subjectivity moved by the goodness of the other. Similarly, in the text discussed here ${ }^{150}$, Thomas also articulated a sense of a passivity moved by the contact of another. In this thesis, the moving quality of a relationally causal patient, is referred to as infinite loveableness. This concept, developed to articulate Levinas' sense of the relationality of the Good, emerges in Thomas' last treatment of the Trinity, in which he wrote, "the good is loveable to itself". 151

Through reversing the ontological order of ends that are passive to their origins and introducing the sense that origins are passive to their ends, the sense of loveableness expresses a kind of causality that cannot be described through ontology. It articulates the sense of relational causality, a sense that pervades but is never named in Thomas's metaphysics. This is sufficient to describe the way in which Levinasian thought pervades the methods of this thesis.

\section{Part C: The Thesis Itself}

The thesis is that the sense of loveableness provides the radical distinction between relationship and identity and that this sense is discernible in the history of the Eucharist. The Eucharist signifies subjectively and historically, this synthesis of subjectivity and historicity exhibits the way of traditioning. Both radically subjective and socially responsible traditioning expresses a kind of synthesis that has always been at work in Levinas' phenomenology. Not that the synthesis has always been clearly manifest. At tragic times rational traditioning has even been denied by its professed exponents. Furthermore, this breakdown in the synthesis of subjective ethics and responsible

\footnotetext{
${ }^{149}$ Autrement que, 13.

${ }^{150}$ Compendium 1:45

151 "bonum ..... se amabile est." Compendium Theologiae, 1.45.
} 
sociality is not exclusive to the history of Eucharist. The fact that this crisis was constantly explored by Levinas shows that the coincidence of ethically inspired subjects and ethically responsible societies is extremely rare. He referred to the voice of inspired subjectivity in societies as "prophetic" 152 and he always voiced his esteem for prophetic texts and prophetic subjectivity.

The histories of the Eucharist and phenomenology show their struggles with ethics. However, thanks to phenomenology reflection on the issues of inspiration and responsibility are able to be explored at new depths. These issues make the contributions of Levinas and the Eucharist compatible. They both expose and respond to the concurrence of radical inspiration and social responsibility through a single gift. In the Eucharist, that single gift is the sign of the Eucharist itself. In Levinas' Phenomenology, that single gift is the exceptional face of the other. The desire to exalt such gifts, the Eucharist and the face, produces the passion for this thesis.

This way of traditioning unity may not have been thought through adequately. The author may have misconceived the relationships between the traditions and the enterprise might not achieve what he hopes. But the thesis has the singular benefit of being drawn by the Good. That goodness, regardless of how well or poorly it is described in this thesis, will have had the effect of moving its author and hopefully those who travel with him, into the sway of its overwhelming encouragement.

\section{Conclusion}

As the Introduction shows, the description of the sense of loveableness is dynamic. It involves contributions from various sources. Perhaps the most formative and accessible is that of "inspiration". Levinas talks of being inspired by the other. Inspiration is a preconceptual element that motivates subjectivity to live for the other, in the approach of the other. However, the inspiring loveableness of the other also communicates a sense of worth to the subject who is inspired. Subjectivity is chosen by the exceptional goodness of the other.

These notions are well known to anyone familiar with Levinas. But Levinas has left a challenge to bring these insights into sustainable social expressions. It is for this reason

${ }^{152}$ Levinas, Autrement qu'être, 233-238 
that the thesis focuses on the Eucharist. The Eucharist motivates a tradition. It sustains a sense of transcendent or pre-conceptual loveableness while also traditioning social responsibility. The goal for this thesis is to render these notions thinkable and practical at a popular level. The Eucharist provides one among several expressions of the popular devotion to the good but its excellence directly engages the ultimate issue, the distinguishing of identity and relationship, veritas in caritate. 


\section{Chapter One}

\section{The Primitive Eucharist and the Apocalyptic Sign}

\section{Introduction: "the last supper is the supper that lasts"}

This chapter argues that the Eucharist is a traditional sign that expresses relationship. The chapter is composed of a brief introduction and two main parts. The introduction introduces some basic terms; "sign", "traditional sign", "passivity" and "agency". The first part (A) describes a contemporary Eucharist and its historical foundations. At both ends of the spectrum (contemporary and ancient) its relational form emerges strongly. The second part (B) explores the historical and apocalyptic treatment the Eucharist receives in the New Testament. This focusses the relational depths of the sign.

\section{The Meaning of "sign" and "traditional sign"}

Before undertaking the argument, it is necessary to explain what is meant by "sign" and "traditional sign" in this thesis. Augustine's definition of a sign makes a good starting point. "A sign is a thing, which besides the impression it conveys to the senses, also has the effect of making something else come to mind." ${ }^{\text {153 }}$ This very broad definition could include a street sign, "which besides the impression it conveys on the senses also has the effect of making" a particular street "come to mind". A word has the effect of that which is being talked about coming to mind. According to Augustine, creation has the effect of making God come to mind. A sacrament has the effect of making Christ come to mind.

But some points need to be raised in relation to this definition of a sign. Firstly, this definition does not distinguish between the way signs express relationship and the ways they express identity. Signs refer; they make things come to mind. This statement relates signs to "things",

\footnotetext{
153 "Signum est enim res praeter speciem, quam ingerit sensibus, aliud aliquid ex se faciens in cogitationem venire," Augustine, De doctrina christiana II.1.1 (CCSL 32.32). Cited by Susannah Ticciati in "The Human Being as Sign in Augustine's De doctrina Christiana”, Neue Zeitschrift für systematische Theologie und Religionsphilosophie 55, no. 1 (January 2013), 25.
} 
"identities". But signs also communicate, they express a sense of relationship between the people using those signs. This point was not developed by Augustine. But the difference is important.

One way of making the point is to distinguish between the word and the voice. Through the use of words, a reference may be made: "this is my home". Through the tone of voice the person speaking may communicate -"this is my home [and I'm happy to share it with you]" or "this is my home [and I'm not happy to share it with you]." The voice is one way, although it is not the only way, in which the distinction between the relational and identifying sense of signs can be portrayed. Also, the voice does not always succeed in communicating this distinction. However, the reference to the voice clarifies the point that the word is a logical form of signification, while the voice involves an attitudinal aspect of signification. With the words - "this is my home", logical information is imparted to the listener. The words perform a reference. But those words do not necessarily communicate a relationship. The sense of relational communication may or may not be imparted with the identifying reference "this is my home".

A further expression of the communicative sense of the sign, as distinct from its referential sense, is evident in Karl Barth's reference to the word made flesh. He writes, "ó $\lambda o ́ \gamma o \varsigma$ бò $\rho \xi$ $\dot{\varepsilon} \gamma \varepsilon \dot{\varepsilon} \varepsilon \tau 0 . . .($ John 1:14) - preaching, too, can and must say this. But in a way which preaching can never do, the sacrament underlines $\sigma \grave{\alpha} \rho \xi$ and $\dot{\varepsilon} \gamma \varepsilon \dot{v \varepsilon} \tau$... The sacrament's insistence upon this quality in sign-giving is its special feature as compared with preaching and its special feature..." ${ }^{\prime 154}$ The distinction between words and the sign is clear. In preaching, words say "the word was made flesh", but through the sacramental sign, the flesh says, "the word was made flesh".

Nor is the sacramental sign just any sign. It is given the form of common food and drink. Food and drink are significant for the flesh. Without food and drink the flesh cannot live. Therefore, when the word becomes flesh in the signs of common bread and wine, it brings its own sense of support to the flesh. It becomes one with the flesh, in being eaten and drunk. Similarly, the food a mother gives to the child in her womb is a word made flesh. It expresses the bond of relationship while it nourishes the bodily life of the child. In the sacrament, the food and drink are signs. In that sense, they differ from the physical value of the mother's food; their necessity as physical food. But they are similar in that they provide a nourishing

${ }^{154}$ Karl Barth, Church Dogmatics, Vol. 1, Doctrine of the Word of God, part 2, 230. 
relationship which cannot be put into words. The word, or rather, the sign of the food, is the fleshly sense of relationship through which nourishment is given. Due to the bodily immediacy of nourishing relationality the Eucharistic sign communicates in the flesh in ways that are impossible for narratives and didactic references.

These points clarify the emphasis in this thesis. It is concerned with the communicative sense of signs, the sense that cannot be put into words, except perhaps in poetry or prayers. Then the words may testify to the bodily devotion of one for another. The body is basic to the meaning of signs.

A sign is traditional when it is handed on through time, from one generation to the next. In being handed on it testifies to the meaning and the value of the relationships that have produced it. Where a sign is traditional, the sense the sign brings to mind, - which is other than the appearance of the sign itself, - will probably include the sense of a remembered event. However, it does not only include the sense of the remembered event. Most significantly, it expresses the value of the relationships through which it has been handed on or traditioned. Being handed over in the relationships that sustain the sign is not the only sense of the traditional sign but it is an indispensable fact of its historicity. In the case of the Eucharist the sign refers to an historical event. It also has a metaphysical sense and a revealed sense, given to the unconditional intuition of faith. The metaphysical and intuited senses, are fruits of its traditional sense. The sign itself signifies in the historicity of being handed on from one generation to the next. After the instituting event, beneath the grasp of metaphysics and the gift of faith intuition, it witnesses to an infinite depth of relational surrender. A tradition is sustained by a sense of surrender in the traditum. If relationships between generations are not accepted, traditions cannot survive. The traditum, or gift that is traditioned, carries the sense of relational acceptance from one generation to the next. The degree of relational acceptance expressed in the handing over and receiving of the traditum may be conditional or unconditional. Where it is unconditional, the traditum expresses a kind of law of forgiveness. The traditum expresses the sense of forgiveness through an unconditional surrender to relationship.

This point can be learned through a reflection on Chrysostom's contemplation of the sacrament in his "treatise on priesthood": 
"Oh! What a marvel! What love of God to man! He who sits on high with the Father is at that hour held in the hands of all, and gives Himself to those who are willing to embrace and grasp Him. And this all do through the eyes of faith!"155

The sign not only brings the mind to things that are higher than the signs themselves. It also leads the mind to think on the "superlative humility of the Good". ${ }^{156}$ When, "He who sits on high with the father is at that hour held in the hands of all" he is not sitting "on high with the father". He "is in the hands of all". The intuited marvel is that the communicants are gathered in the midst of eternal Glory at the Eucharist. But Jesus' being "held in the hands of all" through the sacrament is deeper than the intuition. He expresses a depth of surrender into which the communicants are only hoping to enter. This cannot be comprehended. It is the infinite humility of the one who has been "handed over into the hands of men"157. Those who are "willing to embrace and grasp" fall into the way of his incomprehensible humility. They only appear to grasp him. But the revolution is too profound for them to grasp. They are grasped by him, grasped by the obsessing depths of his intangible humility, learning to "follow the lamb wherever he goes". ${ }^{158}$

This turn from the act of grasping into the humility of following is the work of the traditional sign, the traditum. The disciple is always in the wake of its infinite and ungraspable leadership.

\section{Of Passivity and Agency}

The traditioning of the Eucharist, the attractiveness of the "lamb who was slain" does not only engender passivity in the disciple. It also moves the Father, the unmoved mover. Thomas Aquinas' unique testimony to this astonishing passivity will be explored in chapter 3 . But it is also evident in scripture. John's Gospel has Jesus the good shepherd say, "this is why the Father loves me. Because I lay down my life in order to take it up again...This command I have received from my Father." The Son, who is passive to the Father's command, moves the Father to love him. The beloved moves the lover to love. This must be the deepest point about relational passivity (though who is qualified to say). But at this point it is necessary to note a formidable characteristic of relational passivity. It produces relational agency. "I lay

\footnotetext{
${ }^{155}$ Chrystostom, Treatise on the Priesthood, 3.4. https://www.ewtn.com/library/PATRISTC/PNI9-1.HTM, accessed Feb 2015.

156 See Levinas Autrement qu', 25.

1571 Cor 11:23.

${ }^{158}$ Rv 14:4.
} 
down my life in order to take it up again"159. The Son's passivity to the "command" awakens in him the agency ("power") of "taking up" his life again. This is agency as a kind of ripening fruit of passivity. Crucial to this point is recognition that this agency is not an individual agency. It is a relational agency. It is the agency of resurrection, the overflow of surrendered loveableness into the active life of loving.

The journey into the discernment of ethical agency can be long and tortuous. At times, in the pages ahead it will look as though this thesis is about nothing but the passivity of infinite loveableness. But that passivity is open to agency, for the sake of the other. Agency arises out of passivity, just as passivity comes about because of relationship. Agency and passivity, on the basis of relationship, signify of and for the other.

In exploring the Eucharist, it is impossible to dispense with expressions of the sense of infinite passivity. Christ was "obedient unto death, even death on a cross"160; "The Lord was handed over" ${ }^{\prime 161}$. But this infinite passivity does not exclude agency. Infinite passivity is an ethical not an ontological passivity, a passivity to holiness. Holiness can and does move the ethically passive subject to act.

To appreciate how this movement from passivity to agency comes about it is necessary to grasp the sense of inspiration. The one who is ethically inspired is passive to the alterity of inspiration and is moved by the inspiration of the other. But this is not an ontological passivity. It is a relational passivity. A passivity that produces a tension in the passive subject. The tension is between waiting and acting. The passivity is not inert but restless. Rest is still a worthy aspiration but the difference between rest and restlessness is not the difference between passivity and agency. Passivity and agency are dynamically united in the movement towards rest. The more passivity finds rest in the gift of loveableness, the more it is strengthened to act in response to the loveablenss of the other.

\section{Passivity and Agency in the Traditioning of the Eucharist}

This synthesis of passivity and agency is well known in the history of spirituality. It may be clarified through a brief reflection on the life and teachings of Teresa of Avila. She entered a Carmelite convent without being able to contemplate. Then she received gifts of

\footnotetext{
159 Jn 10:17.

${ }^{160}$ Phil 2:10.

161 Cor 11:23.
} 
contemplation, and after a time, the gift of exceptionally gifted practical leadership. To describe this development Teresa took the Lukan narrative of Martha and Mary ${ }^{162}$. Martha was exercising active hospitality and complained that Mary was not doing anything ${ }^{163}$ Mary was exercising contemplative hospitality, sitting at the feet of Jesus ${ }^{164}$. Jesus praised Mary for "choosing the better part" 165 . Teresa testified to this next stage of development by saying that after a time Martha and Mary hold hands. ${ }^{166}$ The union of the active and contemplative lives, sometimes called "apostolic life", is described in this thesis as "relational agency".

Teilhard de Chardin, influenced by John of the Cross, modelled his spiritual classic Le Milieu Divin $^{167}$ on the same sense of spiritual development. The first part of the book was concerned with "action"168. The second was concerned with "passivity"169. The third part of the three part book united the active and passive dynamics of the spiritual life. It was also profoundly relational and described spiritual communion. It was called "the Divine Milieu" 170

The same pattern is evident in the structure of the eucharistic liturgies. The gifts are brought to the altar and offered up. There is a strong theme of exaltation. This is a liturgical form of action. This is followed by the prayers for the power of God to descend on the signs of bread and wine, that they may become the body and blood of Jesus. This descending of God articulates the motive for passivity; passivity in the prayerful disposition of the assembly and in the surrender of the signs of bread and wine. With the reception of communion all horizons of the celebration are brought together. The Liturgy concludes with the bringing together of the active and passive elements of the unitive Christian life.

\footnotetext{
${ }^{162}$ Lk 10:38-42.

${ }^{163}$ Lk 10:40.

${ }^{164}$ Lk 10:39.

${ }^{165}$ Lk 10:42.

166 Teresa of Avila, The Interior Castle or the Mansions. Edited by Zimmerman Benedict. Grand Rapids: Michigan, 2006, 127-132.

${ }^{167}$ Pierre Teilhard de Chardin, The Divine Milieu: An Essay on the Interior Life, New York: Harper Torchbooks, 2001.

${ }^{168}$ The Divine Milieu, 49-73.

${ }^{169}$ The Divine Milieu, 74-111.

${ }^{170}$ The Divine Milieu, 112-149.
} 


\section{Part A: A Contemporary Eucharist and its Historical Foundations}

To help develop a sense of the relational dynamics of the Eucharist the chapter will now describe a liturgy. It is a liturgy at which the author presided. It is not a model of best liturgical practice; nor does it express an exemplary liturgical awareness. It is limited by the priest's awareness and does not give adequate voice to the congregation's awareness. But limited awareness is intrinsic to an individual's involvement in a liturgy. Given these limitations, it could almost be called a typical liturgy, but liturgies are too diverse for any of them to be called typical. Many Christian denominations celebrate the liturgy quite differently to the following liturgy. This solitary Roman Catholic liturgy would not be able to comprehend all the aspects of the Eucharist.

The purpose of this section is to display the Eucharist. This particular and local liturgy exhibits strong bonds with universal and ancient liturgies. The conjunction of these universal and local, along with ancient and contemporary factors makes for enlightening reflections at times.

The Eucharist entered the New Testament era as a Jewish celebration (circa 30 CE) and left it as a Greek celebration (circa $90 \mathrm{CE}$ ). Yet as a Greek celebration, or even as a contemporary celebration, inalienable expressions of relationship adhere to the celebration of the sacrament.

\section{The Ancient and Contemporary Eucharist}

\section{(a) A Canonically Authorised Eucharist in Wellington}

The church of Saint Joseph's Parish Upper Hutt seats approximately 500 people. The seats face its front - a large, sparsely furnished worship space ("the sanctuary"). In the centre of the sanctuary on a raised part of the floor, stands a marble altar (one metre high, three metres long). Behind and above it, a four metre high crucifix hangs on the wall. About five metres to one side of the altar a slightly ornate chair faces the congregation. On the opposite side, about eight metres from the altar, a lectern faces the people. On the wall behind and to the side of the altar sits a tabernacle. The arrangement of the seating and the altar provides the setting for a dialogical ritual in which the people and the priest face each other. 
Sunday May 7, 2017 was typical for the parish. The priest and parishioners celebrated three eucharists. A Saturday evening vigil, and two on Sunday morning (9:00 and 10:30 a.m.). The three liturgies followed substantially the same order of service although the congregations were different at each mass. The 10:30 a.m. mass had the informally added ingredient of a children's liturgy; that mass, or eucharist, was celebrated as follows:

(i) The Gathering

About 150 parishioners gathered. Generally, they greeted those with whom they entered the building. Another ten parishioners and the priest, were gathered separately to prepare for their leadership roles. Three of these were children - altar servers dressed in soutanes; one was to carry a processional crucifix, the others held a candle each. With their candles, and later with bread, water and wine, they would assist the priest in furnishing the altar. The other seven were adults. One was to convoke the people, introduce the celebration and lead some prayers; two others were to read the scriptures; one was to lead the singing of the Psalm (after the first reading) and the three others were to assist in the distribution of Holy Communion. The priest wore white vestments, the Easter colours, to celebrate the resurrection.

The celebration began with the first leader greeting the people from the front of the church and telling them it was the "Fourth Sunday of Easter, known as 'Good Shepherd Sunday'. Then he invited the people to sing. During the opening hymn the other ministers processed behind the server with the crucifix, to the front of the church. There they all bowed to the altar. The priest walked up behind the altar and bowing kissed it, then went to his chair to face and greet the people. He shared an informal greeting with them, then led the sign of the cross in Te Reo. This last act completed the opening of the liturgy, as prescribed in the official liturgical text; a time of shared prayers had begun. A formal greeting to the people followed, "the Lord be with you". The people responded, "and with your spirit".

Next was a penitential rite. The priest invited the people to silently consider their sins and need for God's mercy. After the time of silence, the priest and people prayed antiphonally, "Lord have mercy", "Christ have mercy". Then, having expressed agreement through the antiphonal form, the community as one expressed their worship of God in the singing of the "Gloria". 


\section{(ii) A Real Life Situation}

During the singing of the Gloria a woman in charge of the children's liturgy came forward to get the priest's attention. He had forgotten to call the children forward, to attend the children's liturgy. At the end of the Gloria, he went to where the children were congregating. The people stretched out their hands towards the children, to bless them. The priest laid his hands on their heads and said a blessing. The children and a teacher went out for a children's liturgy of the word. A few quiet laughs ensued from this unplanned restructuring of the ceremony.

(iii) The Liturgy of the Word

Returning to the formal liturgy meant that the priest read a prayer, from a missal, for the fourth Sunday of Easter. This was an opening prayer that is "proper" to the Fourth Sunday of Easter $^{171}$. A time of silence preceded the prayer. Once the prayer was said two parishioners read the first two readings. Everyone sat for the readings. Between the readings the congregation and a cantor sung a psalm, antiphonally. After the readings everyone stood and sang an "alleluia", then the priest read the Gospel. All the readings focused on the image of "the Shepherd". They were, Acts 2:14, 36-41; Psalm 22:1-6; 1 Peter 2:2-25; John 10:1-10. After the readings, the priest's homily also focused on the theme of Christ the Shepherd.

The liturgy of the word concluded with the community professing the Apostle's Creed, ${ }^{172}$ then intercessory prayers were said by the person who introduced the mass. This ended the first part of the mass; "the liturgy of the word".

(iv) The Liturgy of the Eucharist

After the liturgy of the word, the liturgy of the eucharist began. First there was a preparatory phase which is called the 'offertory' or the 'presentation of the gifts'. Once the gifts had been presented the Eucharistic prayer began. (There are 12 parts to the Eucharistic prayer. In the text below, these are indicated by roman numerals.)

\footnotetext{
${ }^{171}$ Catholic Truth Society, New Sunday Missal, 377.

${ }^{172}$ New Sunday Missal, 543.
} 
To start the offertory, the congregation sang a hymn and a collection was taken up. The money from the collection, a basket of food for some (anonymous) people in need and the gifts of bread and wine were brought forward from the back of the church. The people carrying the money and the food placed them at the foot of the altar while those carrying the bread and wine gave them to the priest. He and the altar servers took the gifts of bread and wine to the altar. There, with more dialogical prayers between himself and the congregation, the priest placed the bread and wine on the altar.

In a traditional antiphonal formula, the celebrant invited the people to share and assist in the offering that was about to be made:

Priest: Pray my brothers and sisters that my sacrifice and yours will be acceptable to God our almighty father.

People: May the Lord accept the sacrifice at your hands for the praise and glory of his name, for our good and the good of all his holy Church. ${ }^{173}$

Then, using the missal for the second time, the celebrant prayed the prayer over the offerings. He used the first-person plural, it was grammatically inclusive: "we pray that we may find delight in these paschal mysteries so that the renewal constantly at work within us, may be the cause of our unending joy. Through Christ our Lord"174. The people agreed: "Amen".

Next, with the priest's hands raised, he and the people performed another dialogical prayer, (I. the Sursum Corda):-

Priest: The Lord be with you.

People: And with your spirit.

Priest: Lift up your hearts.

People: We lift them up to the Lord.

Priest: Let us give thanks to the Lord our God.

People: It is right and just. ${ }^{175}$

A traditional prayer of praise (II. the preface) ${ }^{176}$ followed. Its conclusion led into the congregational singing of iii. the Sanctus:-

\footnotetext{
${ }^{173}$ New Sunday Missal, 547.

${ }^{174}$ New Sunday Missal, 378.

${ }^{175}$ New Sunday Missal, 547.
} 
Priest: The heavenly powers, with the angelic hosts sing together the unending song of your Glory, as they acclaim:

People: Holy, holy, holy Lord God of hosts... Blessed is he who comes in the name of the Lord, Hosanna in the highest. ${ }^{177}$

From this point on, the priest continued to voice the prayer to God the "Father", while the people knelt in prayerful agreement. After a few sentences (III. the post-preface part 1) the priest's attention turned to the bread and wine ${ }^{178}$. He asked God to "sanctify" these elements through his "Holy Spirit", "that they may become the body and blood of your Son our Lord Jesus Christ, at whose command we celebrate these mysteries" (IV. post-preface part 2). In this particular eucharistic prayer, the second part of the post-preface is also the first epiclesis $^{179}$.

Then the priest recalled the last supper with the words - "on the night he was betrayed" (V. the institution narrative). Taking the bread and holding it above the altar, he repeated the traditional and predominantly scriptural words of Jesus - "take this all of you and eat of it, for this is my body which will be given up for you". ${ }^{180}$

He did the same with the wine - "take this all of you and drink from it for this is the chalice of my blood, the blood of the new and eternal covenant, which will be poured out for you and for many for the forgiveness of sins. Do this in memory of me". ${ }^{181}$

He then genuflected before the ritual signs of bread and wine. This was the only genuflection he made during the mass. The people, still kneeling, then sang a short verse celebrating the death, resurrection and return of Jesus (VI. the veneration of the sacrament and acclamation of faith $)^{182}$.

The priest continued - "Therefore, O Lord, as we celebrate this memorial of the saving Passion of your Son, his wondrous Resurrection and looking forward to his second coming, we offer you in thanksgiving this holy and living sacrifice". (VII. the anamnesis) ${ }^{183}$.

\footnotetext{
${ }^{176}$ New Sunday Missal, 561.

${ }^{177}$ New Sunday Missal, 549.

${ }^{178}$ New Sunday Missal, 611-613.

${ }^{179}$ See Eucharistic Prayer 3, in New Sunday Missal, 610-619.

${ }^{180}$ New Sunday Missal, 613.

${ }^{181}$ New Sunday Missal, 613.

${ }^{182}$ New Sunday Missal, 615.

${ }^{183}$ New Sunday Missal, 617.
} 
The prayer continued, asking God to "favour" the people gathered at the altar of "the sacrificial Victim ...those you have willed to reconcile to yourself ... who are nourished by the Body and Blood of your Son" (VIII. the oblation). May they be "filled with his Holy Spirit and become one body one spirit in Christ" (IX. the epiclesis).

Then followed intercessions for the people to enter into heaven with "the blessed Virgin Mary, Mother of God, Blessed Joseph her spouse, the Apostles... and all the saints". Intercessions were prayed for the peace of the world, for Pope Francis, "our Bishop John", for all priests, deacons and all the people of God. Another prayer for the participants in that mass followed, "hear the prayers of the family you have gathered here before you". Finally, there were prayers for those who have died, that they may enter heaven, and a confession of hope that one day "we" may join them in heaven (X. the intercessions) ${ }^{184}$.

The priest then elevated the consecrated signs saying - "through him, with him and in him, O God almighty Father, in the unity of the Holy Spirit, all glory and honour is yours for ever and ever" (XI the doxology). Together the community sang an "Amen" (XII. the great Amen $)^{185}$.

\section{(v) The Communion Rite}

Again, at the priest's invitation, the people stood and prayed the Lord's Prayer, after which he prayed a prayer of peace. This time the prayer was addressed to "Jesus". (From the opening prayer to the "great Amen" the prayers had been addressed to the "Father"). After the prayer of peace, the priest invited the people to offer each other a sign of peace. Hugging or shaking hands with those near them people said - "peace be with you""

Returning from the peace greeting to the altar, the priest was joined by the other ministers of communion. He broke and distributed the bread to them and to the altar servers. At this time, everyone was singing - "Lamb of God, you take away the sins of the world, have mercy on us. Lamb of God, you take away the sins of the world have mercy on us. Lamb of God you take away the sins of the world, grant us peace." 187

\footnotetext{
${ }^{184}$ New Sunday Missal, 617-619.

${ }^{185}$ New Sunday Missal, 619.

${ }^{186}$ New Sunday Missal, 631-635.

${ }^{187}$ New Sunday Missal, 637.
} 
Holding the consecrated host and the chalice, the priest called out "behold the Lamb of God" and declared "blessed are those who are called to the supper of the Lamb" 188 . Then all said "Lord I am not worthy that you should enter under my roof, but only say the word and my soul shall be healed". ${ }^{189}$

Those at the altar consumed the bread and wine and moved from the altar to the front of the sanctuary. There, with the words, "body of Christ", "blood of Christ", they gave communion to each communicant. The communicants replied "Amen" and received the sacrament ${ }^{190}$. Not all who came forward were communicants. Some simply received a blessing from the minister of the eucharist.

A time of silence followed communion. The priest said a third prayer from the missal, for the fourth Sunday of Easter. This was addressed to God the Father, "Kind Shepherd. Be pleased to settle in eternal pastures, those you have redeemed by the blood of your Son."191 Again the people responded "Amen" 192 .

(vi) The Formal and Informal Processes of Departure

Usually, at that point, the celebration would have ended with the antiphonal formula - "the Lord be with you" and the people would respond - "and with your spirit", followed by a blessing, with the sign of the cross in Te Reo and finally the dismissal - "Go in peace, glorifying the Lord by your lives" to which the people concluded - "thanks be to God". But for this Sunday, the Archbishop, Cardinal John, had sent a letter to be read at all the eucharists in the Archdiocese. It was to inform the people about the coming Synod, September 15-17. It emphasized the pastoral responsibilities of Christians in the world, where so many people suffer from poverty and injustice.

Though the Eucharist had dominated that hour of worship, it was not the focus of the Cardinal's letter. He said that the theme of the Synod was "Go, you are sent!" This was an apt focus for the people leaving the mass. A person at the celebration observed that while the Eucharist is not often spoken about by the people who attend the eucharist, it is a silent priority. Similarly we cannot live without food, yet we only occasionally speak about it.

\footnotetext{
${ }^{188}$ New Sunday Missal, 637.

${ }^{189}$ New Sunday Missal, 638.

${ }^{190}$ New Sunday Missal, 637-639.

${ }^{191}$ New Sunday Missal, 380.

${ }^{192}$ New Sunday Missal, 639-641.
} 
The priest thanked everyone for their involvement and the celebration concluded with a hymn. The people then reconvened for a cup of tea at the back of the Church.

\section{Some Comments about this Eucharist}

(a) The Gathering

The sign of the cross establishes the earthly community of the people in the heavenly community of the Trinity.

(Priest) "The Lord be with you," (People) "and with your spirit". According to the traditional Latin text, formulated in the fourth century by Saint Ambrose this dialogical antiphon is performed four times in the course of the mass. Here, it has introduced the mass as a whole. Later it introduces the reading of the Gospel, and then the eucharistic prayer. Finally, the antiphon introduces the concluding "rite of dismissal". There it functions as an encouraging farewell.

A "time of silence" preceded the prayers for mercy. Silence is intrinsic to the liturgy. It enhances reflection and sustains the sense that the liturgy is a dialogue that involves ineffable elements.

(b) A Real Life Situation

Locally and globally, adaptations to the liturgy, for the benefit of children, form part of the liturgical community's ethos.

(c) The Liturgy of the Word

The opening was "proper" to the fourth Sunday of Easter.

The term "proper" refers to prayers, always at least three, which vary from week to week and from feast day to feast day. Wherever an ancient rite is celebrated a particular prayer is prayed immediately before the readings. The prayer is proper to that day. It differs every Sunday and every feast day. But on any day, the prayer proper to the day is prayed 
throughout the world. The prayer differs from Rite to Rite, rather than from place to place. The readings are also globally agreed, according to the Rite.

The three proper prayers of the Latin Rite are, the opening prayer, or collect - prayed immediately before the readings; the prayer over the offerings - prayed immediately before the eucharistic prayer; and finally, the prayer after communion. The prayers for "the proper of the mass" do not usually relate thematically to the readings. But, in the Latin Rite, on the 4th Sunday of Easter, the opening prayer, the readings and the communion prayer refer explicitly to Christ the Good Shepherd. The Sunday readings are always "proper" to the day.

(d) The Liturgy of the Eucharist - from Word to Sacrifice

The transition from the liturgy of the word to the liturgy of the sacrament is from a linguistically to an existentially communicated relationship, from word signs to body signs. This means the dialogical situation is changed. The time of listening, the offering of the ear, has become a time of sacrifice, the offering of the body. The bodily and not only the linguistic gifts of the people have become invested in the liturgical relationships. This transition is common to all the ancient traditions. It is evident in Justin Martyr's description of the ancient liturgy. ${ }^{193}$

In the ancient church, and in the contemporary Syriac churches, anyone may attend the liturgy of the word. But only the baptized may stay for the liturgy of the eucharist. Today, this is not a common practice in the Greek Orthodox or Western Church. Two main reasons account for the loss of the practice. The first is due to a major historical development. In many ways, the end of persecution and abounding popularity of Christianity after Constantine has made "the discipline of the secret" seem pointless. Everybody could claim to know the secret. The second is to do with social affections. In contemporary Western cultures, the exclusivism of the practice seems uncaring and non-communicative. However, it would not seem uncaring in environments of persecution. The people who stay enter into the liturgy of sacrifice. Prescinding from sociological developments, theologically, the liturgy proceeds on the premise that the people have agreed through baptism, to offer their lives in sacrifice to God with Jesus. The liturgy of the eucharist is the liturgical imitation of the sacrifice of Jesus on the cross.

${ }^{193}$ Justin Martyr, First Apology, Chapter 67, http://www.newadvent.org/fathers/0126.htm, accessed 15/3/15. 
In the contemporary Western Church the signs of a transition from the liturgy of the word to the liturgy of the Eucharist are almost imperceptible. They are a collection plate, an offering of food to be distributed later to those who cannot afford it, and the gifts of bread and wine. However one obvious and most significant change is the focal point in the celebration. The offering of bread and wine is taken to the altar, where it becomes the sacrifice on the altar. The sacrifice seems so little like a sacrifice that it is also appropriate to call it a "meal". Nevertheless, according to the rite, the act of prayer is offered through the gifts of bread and wine, and without these gifts the eucharistic prayer cannot be prayed. It is this material element that signifies the material gift of the people's lives. These points are consonant with the teaching of William K. Gilders that, in the history of Judaism, the offering of sacrifices is a meal celebration of intimacy with God. God delights in the gift of a meal ${ }^{194}$. In Eucharist: Theology and Spirituality of the Eucharistic Prayer ${ }^{195}$ Louis Bouyer demonstrates the Jewish roots of the prayers that are said during the liturgy of the Eucharist. This is particularly evident in the prayers said, while the bread and wine are placed on the altar, "Blessed are you Lord God of all creation. Through your goodness we have this bread [or wine] to offer; it will become for us the bread of life [or our spiritual drink]." Again, the prayer is dialogical. The people respond, "Blessed be God forever"196. It is also evident in the Eucharistic prayers themselves. ${ }^{197}$

\section{(i) The Agreement to Offer Sacrifice}

With the bread and wine placed on the altar, between him and the people, the priest asked the people to pray for their sacrifice as well as his: "pray, my brothers and sisters, that my sacrifice and yours will be acceptable to God the almighty father". The people agreed: "may the Lord accept the sacrifice at your hands..." The motive is for local and universal blessings, "...for our good and the good of all his Church." 198 Through this response, the priest receives the people's permission to proceed in their shared prayer of sacrifice.

\footnotetext{
${ }^{194}$ William K. Gilders, "Sacrifice in Ancient Israel”, https://www.sblsite.org/assets/pdfs/TBv2i5 Gilders2.pdf, accessed March 2015.

${ }^{195}$ Louis Bouyer, Eucharist: Theology and Spirituality of the Eucharistic Prayer, New York: University of Notre Dame Press, 1989.

${ }^{196}$ New Sunday Missal, 545.

197 Eucharist: Theology and Spirituality, 78-84.

${ }^{198}$ New Sunday Missal, 545.
} 
The priest then says a prayer which expresses the motive for the sacrifice on this occasion. It is the second of the proper prayers of the mass; "the prayer over the offerings"199.

At first sight, the prayer proper to the fourth Sunday of Easter seems particularly unsacrificial: "we pray that we may find delight in these paschal mysteries so that the renewal constantly at work within us, may be the cause of our unending joy. Through Christ our Lord. Amen." ${ }^{200}$ How can a sacrificial prayer sound so self-interested? The key to resolving this apparent contradiction is to appreciate that this is a post-resurrection sacrifice. There is mortification in the will to enter into the sacrifice. There is new life in the will of the God who receives the sacrifice.

However, there is also a predilective element that oversteps the moment of mortification. The sacrifice is a post-resurrection sacrifice. Therefore, the outcome of the sacrifice is already known and enjoyed. This point pervades the history of the liturgy and the motivation for this thesis. In advance, the liturgies enjoy the fulness of resurrection life. But, in the midst of this predilection a great paradox of the sacrament comes to the fore. Those who are full of joy and desire to grow in joy are going to celebrate the sufferings of one who has died. "When you eat this bread, and drink this cup you proclaim the death of the Lord until he comes". ${ }^{201}$

In the attempt to account for this strange mix of joy and suffering it may be suggested that the rejoicing is not because of the sufferings of Jesus but because of his resurrection. However, this does not take full account of the liturgical gift. The sense of Jesus' suffering is also intrinsic to the liturgy. Jesus is said to have commanded this remembrance when his suffering unto death began, not when it was ended. "On the night he was handed over... he said... 'do this in the remembrance of me', ,202

The instruction seems strange. "Christ endured the cross for the sake of the joy which lay ahead", ${ }^{203}$ yet the disciple is called to endure the cross for the sake of the sorrow that lies behind. This is clearly counter-intuitive, and it is too early to approach this issue in depth. The idea of drawing strength from another's suffering may seem to offer insight but it doesn't take account of what it means for the other to suffer. It is easy to be simplistic and take the motive for remembering to be the resurrection. But the scriptures place the death of Jesus at the heart of the injunction to remember. The way to the solution is to explore the liturgy. This

\footnotetext{
${ }^{199}$ New Sunday Missal, 377.

${ }^{200}$ New Sunday Missal, 377.

2011 Cor 11:26.

2021 Cor 11:24-25.

${ }^{203}$ Heb 12:2.
} 
also means to explore the Scriptures since, as the following part of this chapter will show, Scripture is the first witness to the liturgy. Therefore, a biblical reflection on the way Baptism leads to the Eucharist will help to expose the Eucharist as a gift of relational remembrance.

(ii) From Baptism to Eucharist through the Revelation of God's Beloved Son

The depth of the Lucan account of the baptism of Jesus ${ }^{204}$ is extraordinary. It describes a diachronic process of anointing and revelation. On the one hand, the heavens are opened; on the other, there is a temporal opening between the time Jesus is baptized and the time the heavens open. Not only that - "the Holy Spirit descended on Jesus in bodily form as a dove"

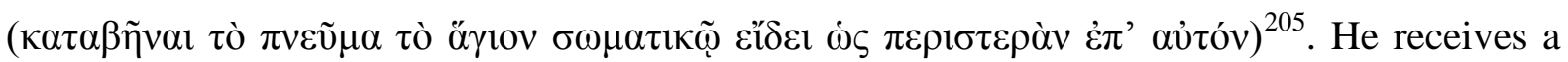
revelation of his loveableness. At the end of his ministry Jesus will send his spirit to God ${ }^{206}$. From there the Father and the Son will send the Holy Spirit on the disciples to impart the new revelation of infinite and unconditional lovableness to those who are waiting and praying in the appointed room. This spiritual flow from God to Jesus, from Jesus to the Father, from Jesus and the Father onto the Church, speaks of a synthesis of Baptism and Eucharist.

Shortly after his baptism from John, Jesus received the Holy Spirit. Shortly after he celebrated the Eucharist, Jesus entered his death and sent his spirit to God. Thomas Aquinas was attuned to something like this flow when he taught that the sacrament of baptism begins the Christian life while the Eucharist is to do with its ending ${ }^{207}$. However, these observations do not get to the core of revelation in Luke 3:21-22. The core is God's word of love to Jesus.

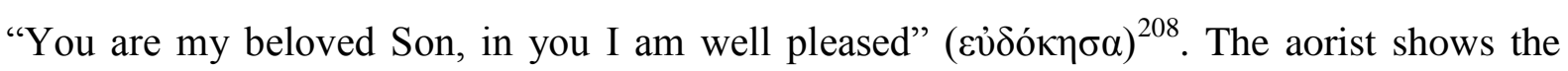
pleasure to be completely given to Jesus. Its destiny is accomplished and established in him. This comes about through a relationship of communication. Henceforth life in the communicative celebration of his loveableness is the life of Jesus. The only movement in the Father's journey will be deeper into the life of Jesus. The challenge in these baptismal texts is to grasp the movement from baptism to the cross as a way of the beloved. This can offer revelation on the meaning of Eucharist. But where can a next step in this meditation on the loveableness of Jesus go?

\footnotetext{
${ }^{204}$ Lk 3:21-22.

${ }^{205}$ Lk 3:22.

${ }^{206}$ Lk 23:46.

207 "Baptismus est principium spiritualis vitae, Eucharistia vero est quasi consummatio spiritualis vitae", Aquinas, Summa Theologica 3.73, 3.

${ }^{208}$ Lk 3:22.
} 
The first matter to grasp is why the Father should love Jesus so much. Although the Father is loving, the priority of the revelation is not in his act of loving. The sense is always portrayed according to the $I-$ Thou logic. The Father loves Jesus because of Jesus. It is this logic that evokes here the term 'infinite lovableness', when referring to Jesus. The words of the Father at the baptism of Jesus testify to the infinite and irresistible lovableness of Jesus, his covenanting lovableness, his binding lovableness. There is nothing new in this. It also pertains to the other baptism accounts. But the challenge is to discover how this revelation, which exposes the heart of baptism, sheds light on the Eucharist.

An indispensable element in this revelation is that according to the baptism accounts, Jesus has an apocalyptic encounter in which his infinite lovableness is revealed to him by God. But he not only accepts this revelation, he communicates it. The journey to Eucharist is a journey into the gift of revealing to others the life of apocalyptic openness. The disciples are also infinitely loveable, the other is also infinitely loveable.

This revelation helps to establish the sense of the Eucharist in the sense of baptism. Liturgically, this is necessary. Because, baptism comes at the beginning of the life of Jesus and Eucharist comes at the end, it is tempting to think of them as decidedly different. But at his baptism the Father expressed his devotion to Jesus and nothing can move that. Therefore, the interpretation of the Eucharist has to somehow be one with the revelation of the baptism of Jesus. This makes it necessary to find another moment, outside the baptism of Jesus, which pertains to Eucharist and expresses this same revelation of his lovableness. The scriptures provide that moment in the account of the transfiguration of Jesus.

The Transfiguration in Luke's Gospel repeats the revelation of the baptism by the Father's voice about Jesus, the chosen $\operatorname{Son}^{209}$. But in the environment of this revelation, the Father does not speak to Jesus about his lovableness. He speaks to Peter, John and James about his "chosenness", and about their obligation to listen to him. They too are chosen. They too have come into the apocalyptic sense of God, but they have to learn how to receive that sense and live in it. Moses and Elijah are there speaking with Jesus about his "exodus" ( $\left.\check{\xi} \xi_{o} \delta o v\right)$ which he was "going to accomplish in Jerusalem"210. This was the way he was going to lead Peter, John and James into the way of apocalyptic victory. After Jesus has died, they have to continue communicating the revelation of Jesus, sharing with others the way of the chosen.

\footnotetext{
${ }^{209}$ Lk 9:28-36.

${ }^{210}$ Lk 9:31.
} 
The way of the one who moves God according to the irresistible force of his or her lovableness.

When Moses and Elijah speak to Jesus about his "exodus", this clearly involves the meal of the exodus, at which Jesus says to his disciples, "with longing I have longed to eat this Passover with you because I tell you I will not eat it again until it is fulfilled in the kingdom of God"211. It might not mean that the transfiguration was defined by a reference to the exodus meal of the Passover, but it does emerge as a crucial element in the prophetic moment of the transfiguration. It reveals his longing for the father and for the kingdom of heaven. The account of the Passover meal in Luke's Gospel is emphatically apocalyptic. It reveals Jesus' gift of imparting the gift of apocalyptic openness to God, through the eucharist.

The apocalyptic horizons of the Eucharist emerge throughout these reflections. The next section of this chapter shows how the apocalyptic communication, described in the Lukan baptism, transfiguration and Passover narratives, also structures the ancient Eucharistic prayers.

(iii) The Eucharistic Prayer

The point has already been made that the Eucharistic prayers begin with an exclusive significance for the baptized. That is why God's children, whom God desires to love with unrestrained kindness, are able to say: "we pray that we may find delight in these paschal mysteries so that the renewal constantly at work within us, may be the cause of our unending joy". The ultimate gift of the Eucharist is ever-increasing acceptance of the gift of baptism. But it is baptism as a communicable gift. A gift through which the unconditional loveableness of the other also comes to life. This is the desire of the kingdom of heaven; joy in the social revelation of invincible and irresistible loveableness. Nevertheless, the transition from the acceptance of revelation to the sacrificial journey of communication is also expressed in the transition from the liturgy of the word to the liturgy of the sacrament. Baptism accepts, Eucharist communicates, but it communicates life in the resurrection.

The following account explains how the Eucharistic prayers serve this apocalyptic dynamic. Firstly, they have an ancient structure to which they all conform, despite slight differences. Secondly, they are dialogical in nature.

${ }^{211} \operatorname{Lk} 22: 15-16$. 


\section{The Sursum Corda}

With the gifts between the people and the priest, the priest says "lift up your hearts" $" 212$. This gives an eschatological or apocalyptic orientation to the prayer.

II The preface recounts the work of God in Jesus, who has led the people at the liturgy, and people throughout history to new life before God.

III The Sanctus is introduced with the words - "Therefore with the angels and saints we sing their song of praise, Holy, holy, holy, Lord God of hosts, heaven and earth are full of your Glory. Hosanna in the highest."

To this point the eucharistic prayer has been one of ascent, but now, out of the apocalyptic song, - the "Holy, holy" - comes a new dynamic, one of descent! "Blessed is he who comes in the name of the Lord". The last verse of the Sanctus establishes that the descent of the one who comes does not reduce the heights of heaven, but re-energizes them "Hosanna in the Highest"

IV the post-preface sustains the theme of holiness rather than of height. The celebration is in the proximity and encompassing of holiness. Nevertheless, this is a holiness that descends. "Yes, Lord you are holy, indeed you are the fount of all holiness. Let your spirit come upon these gifts" 213 .

$\mathrm{V}$ the institution narrative is not included in the Holy Qurbana of Addai and Mari ${ }^{214}$, prayed in the Eastern Syriac Rite. The bestowal of holiness in the bread and wine is accepted on the basis of the offering itself. Nevertheless it is still offered in the last-supper tradition of Jesus $^{215}$. In other rites the words of institution are generally said in the same or very similar words to those recounted above $\mathrm{e}^{216}$. Words in the mass recounted above were "this is my body which will be given up for you"; "this is the cup of my blood which will be poured out for you and for the forgiveness of sins. Do this in memory of me."217 These words bind the sign and the cross. Through these words the environment, gives way like death to the voice of God's life, it gives way to the one who comes. Therefore, although the priest said the words,

\footnotetext{
212 Throughout this section the references to the prayers of the mass repeat those given above, 58-9.

${ }^{213}$ New Sunday Missal, 605.

${ }^{214}$ Bradshaw and Johnson, The Eucharistic Liturgies, 39.

${ }^{215}$ The Eucharistic Liturgies, 39-40.

${ }^{216}$ The Eucharistic Liturgies, 76-77.

${ }^{217}$ New Sunday Missal, 613.
} 
his words were only a sign of the words and voice of Jesus. The celebration is the expression of his risen and covenanting voice.

VI the veneration of the sacrament and the acclamation of faith this simply extols Jesus for his death and resurrection and sings a song of praise.

VII the anamnesis and all that follows -VIII the oblation IX epiclesis X intercessions XI doxology and XII great Amen - celebrate the binding covenant in the faithfulness of God. God remembers the people and the people remember God in the invincibly communicated and eternally loveable gift of God's Son.

(e) The Communion Rite, and the Symbolism of the "Lamb of God"

Symbolism and rhetoric concerning the "Lamb of God" are a high priority in the ancient and universal practices of the eucharist. The "lamb of God" in the Latin Rite has already been mentioned in the discussion of the communion rite ${ }^{218}$. However, the traditional liturgical esteem for the Lamb of God is given exceptional emphasis in all the ancient anaphora. Many of them begin by cutting a piece of bread from the bread that has been prepared for the liturgy (the prosphora) and taking it to the altar for the anaphora. That piece is called "the Lamb of God who takes away the sins of the world ${ }^{219}$

\section{Particular and Universal Characteristics of the Celebration}

How does a sketch of a contemporary celebration of the eucharist disclose the sense of an ancient event? The difference between the enduring and occasional elements of the Eucharist is an abiding difference. Two millennia of history provide many different kinds of Eucharist, in many different situations. But there are also elements of constancy. This ongoing tension between identity and change is itself a constant. If the tension ceases to exist, then the eucharist, in its creative sense, would have also ceased to exist.

Over the last two centuries critical studies have sharpened the awareness of the occasional elements. Many features of the Eucharist which were once held to be enduring are now shown to be provisional. How can anyone be confident that an enduring element can be identified, one that will outlast this critical phase of history?" This thesis does not begin with

\footnotetext{
${ }^{218} \mathrm{Cf}$ above, chap. 1, part A, section 1, (a), (v), p. 60.

${ }^{219}$ Bradshaw and Johnson, The Eucharist Liturgies, 143.
} 
an answer to that question. It simply explores the Eucharist. But for all that, a secret of survival seems to have inscribed itself in the history of the sacrament. The Last Supper is the supper that lasts. Somehow the blending of the contemporary and the ancient forms the traditional strength of the Eucharist. The relational community exists diachronically. It is inevitable that it would involve contemporary and ancient elements. Having distinguished some ancient enduring elements from the contemporary, provisional elements, the second part (B) of this chapter will explore the ancient history of the eucharist.

\section{(a) Particular characteristics}

The celebration recounted above is a mixture of particular and universal elements. In particular it was a Roman Catholic Eucharist celebrated in a typical New Zealand town in an urban area. It was said in English, with some minimal expressions of Maori. It was emphatically institutional rather than charismatic. It lasted for the conventional length of approximately one hour. It was conservative and did not depart from the status quo practices of the local church. It was somewhat priest-centred.

These particular characteristics show that it was a genuine but not an all-inclusive eucharist. A eucharist can be only one kind of eucharist at a time. But there is a universality which comprehends its immense diversity of forms. It may be Greek or Russian Orthodox; Coptic or Eastern or Western Syriac; Anglican or Episcopalian. There are many other possible varieties. All these linguistic and cultural varieties may be canonically accepted as part of the overall Latin Rite (the Roman Catholic Church). However, the above practices would also work well in an Anglican or Episcopalian Rite. It is also the case that eucharists are often celebrated outside the canonical identity of those Rites. They have their own ancient identity. Additional to the Rites mentioned above are the Lutheran, Calvinist, Anabaptist, Methodist, and many other expressions of eucharist in the world today. Though these liturgies are postreformation, they also have roots in the ancient traditions of the eucharist and not only in the biblical narratives.

The liturgy was emphatically institutional. In the church of the first century participants at the eucharist prayed in tongues and prophesied. In some church environments today, the gifts of tongues prophecy, spontaneous healing prayer and deliverance prayers have once again become common place. Most often these are not environments formed by the eucharist. The 
spiritual charisms of 1 Corinthians 12:7-11 were not evident at the liturgy at St. Joseph's, even though some of the parishioners and the priest personally prefer that type of prayer.

The national situation of the eucharist at St. Joseph's also impacts on it. It belongs in Aotearoa-New Zealand. The priest and an unknown percentage of the congregation feel a need to express those elements of Māoritanga that resonate with the Eucharist. This fact demonstrates how a celebration, according to the norms of a particular culture, cannot be impervious to the influences and needs of those other cultures that share its historical environment. Issues of particularity and universality interweave in the local environment in ongoing and ever contemporary ways.

The homily was about ten minutes, the liturgy took about an hour. While eucharists may sometimes be celebrated as part of a peace and social justice protest, that was not the case with this liturgy. On the other hand, if contemporary political symbols of peace and social justice were expressed in conformity with the theme of the Good Shepherd that gesture would have been welcomed by the majority of the congregation. Peace is intrinsic to the liturgy. Nevertheless, the absence of themes of anti-war protest, or other deprecations of common place injustice further indicated that this was a conservative liturgy celebrated in a treasured climate of peace.

The presider was a man. In some rites developed since the reformation there is a strong possibility the priest will be a woman. This topic raises a point of dispute about what may be called universal and what may be called particular. Is it a departure from the universal sense of the eucharist for a woman to preside at the eucharist? Or is it a departure from its universal sense if the presider is necessarily a male? Or, given the diverse expressions of the eucharist, are both determinations of the universal acceptable? This last prospect may seem strange but the eucharist allows diverse possibilities. How is the universal sense discerned?

\section{(b) Universal characteristics}

Some elements are clearly eucharistic universals. The celebration was based in a sense of the Trinity. A presider led the liturgy. The progression of the liturgy was structured dialogically; "the Lord be with you", "and with your spirit". The celebration began with a prayer for mercy. The readings were preceded by a prayer. The readings were biblical. There was a homily. The liturgy was composed of two main parts, a liturgy of the word and a liturgy of 
the sacrament (or liturgy of the eucharist). The most constant speech acts during the liturgy of the word were narrative and didactic. The most constant speech act during the liturgy of the eucharist was prayer. This was coupled with the dramatic (liturgical) imitation of the words and gestures of Jesus, according to the biblical and traditional last supper narratives, i.e. "the night he was betrayed". According to Cyprian 253, the eucharist is necessarily modelled on the last supper. Also, according to Cyprian, the signs of bread and wine are inextricably bound to Jesus' anticipation of his death; the bread represents his body, the wine represents his blood. ${ }^{220}$ Therefore, the liturgical imitation of the words and gestures of Jesus over the bread and wine, embeds a sacrificial sign-act in the prayerful speech-act of the eucharistic prayer.

Further to the above universals, some diversity exists among the Rites. However, there are basic elements and a structure common to the ancient traditions. The liturgy of the eucharist has the structure of prosphora (bread and wine are prepared and brought to the priest), anaphora (they are offered from the altar) and communion rite (they are received by the people of the community). The first part differs greatly from tradition to tradition but, since the fourth century, the Anaphora (Greek Orthodox), Qurbana of the Eastern and Western Syriac traditions and eucharistic prayer (Roman Catholic) have had a remarkably common structure $^{221}$. This is with the exception of the most ancient Eastern Syriac anaphora of Addai and Mari. It differs a little. It dates from the second century ${ }^{222}$ and had been established before the more detailed forms of the prayer had been composed. But otherwise the common structure of the eucharistic prayers, progresses from (I) the sursum corda to (XII) the great Amen, through the stages recounted above.

After the Eucharistic Prayer, the Communion rite was celebrated. This included the Lord's Prayer, a prayer for peace, and a peace greeting. There was an emphasis on the Lamb of God. After the eucharistic prayer, the Lord's prayer, the acclamation of the Lamb of God and a prayer for mercy and peace, the people received communion. They did not go and get communion for themselves but received communion from an appointed minister. The liturgy expressed the faith that, through the consecrating gift of the eucharistic prayer, the bread and wine were now changed into gifts of the body and blood of Jesus. The majority of the people believed they were receiving the body and blood of Jesus Christ when they received

\footnotetext{
${ }^{220}$ Cyprian, "Epistle LXII," para. 2.

${ }^{221}$ Bradshaw and Johnson, The Eucharistic Liturgies, 36-44, 77.

${ }^{222}$ The Eucharistic Liturgies, 39.
} 
communion. The authority of the bishop was respected. The people were dismissed after the Trinitarian blessing.

In summary, in accord with a universal tradition, the eucharist was structured dialogically. Antiphons occurred throughout the liturgy - at the beginning, through the Liturgy of the Word, the Liturgy of the Eucharist and the Conclusion. But can the roots of these relational elements of the Eucharist be found before their appearance in the liturgies of the second century?

\section{Part B: Historical and Apocalyptic Treatment of the Eucharist}

\section{A Reflection on the Origins of the Eucharist}

Denis Farkasfalvy, in "The Eucharistic Provenance of the New Testament Texts,"223 has given an informative treatment of the origins of the Eucharist. Francis Martin's "Response to Denis Farkasfalvy" 224 is in agreement with Farkasfalvy though he adds valuable observations. Farkasfalvy, at the beginning of his paper, acknowledges six standard sources for seeking out the primitive eucharist: (i) last supper accounts (ii) John 6 (iii) eucharistic features of resurrection narratives in Luke (once) and John (twice) (iv) eucharistic practices in Acts (v) studying Paul's Christology and ecclesiology and (vi) the eucharistic references in the book of revelations. ${ }^{225}$, Having presented this list, he refers to yet another approach (vii) demonstrating, that "the New Testament is the product of apostolic church's eucharistic practice". ${ }^{226}$ By this approach Farkasfalvy does not so much explore the scriptures to achieve a greater understanding of the genesis of "the eucharist provenance"; rather he explores the sense of fidelity to the historical Jesus, sustained through the eucharistic gatherings, as a way of learning more about the scriptures. Once "the eucharistic provenance of the new testament texts" is established, it becomes easier to appreciate not only the explicit, but also the implicit references to the eucharist that pervade the New Testament...

Responding to Farkasfalvy's and Martin's research, this thesis notes other treatments of the eucharist to add to the six textual approaches Farkasfalvy mentions and the traditional

\footnotetext{
${ }^{223}$ Dennis Farkasfalvy, "The Eucharistic Provenance of New Testament Texts," 27-51.

${ }^{224}$ Francis Martin, "Response to Denis Farkasfalvy," 52-62.

225 Farkasfalvy, 27.

${ }^{226}$ Farkasfalvy, 28.
} 
approach he explores. These additional approaches are numbered in continuity with Farkasfalvy's numbering- listed from (viii) - (xii). Exploring (viii) the already oft reported, eucharistic elements of the Letter to the Hebrews and - as with Farkasfalvy - an appreciation of the general eucharistic environment in which the New Testament was written. Part of Farkasfalvy's insight also involves appreciation that the eucharistic provenance of the New Testament (ix) includes the Hebrew Scriptures, and other primitive liturgical texts (hymns such as Philippians 2:7-11, Ephesians 1:3-17, etc.). They came into Christian prominence and entered the New Testament through the liturgical gatherings. Therefore, it is necessary to study the inclusion of the Jewish and primitive Christian texts as part of the primitive liturgies. A further corollary is that there is a need to explore the dynamics of the eucharistic traditions involved in the genesis of the biblical texts. Therefore, in addition to the above approaches there is a need for (x) a study of the eucharistic features and vocabulary in the Lucan tradition, and in (xi) the Johannine tradition. But most importantly, once the eucharist in the New Testament is glimpsed according to its traditional facticity, it becomes impossible to consider the eucharist without exploring the question of the meal tradition of Jesus himself. These were (xii) the Jewish liturgical-meals that provided the pre-New Testament sign, the sign which Jesus practiced.

It is interesting to note the division into which the above approaches fall. (i) to (vi) concern approaching the eucharist through its textual references; (vii) to (xii) concern approaching the eucharist through its traditional interconnections. Both approaches are indispensable. The textual references keep the tradition in view. The traditional interconnections render the sign, at least partially, available as an historical sign and not only a textual referent. The sign has its own temporal (or historical) horizons and not only the horizons provided by the textual references. Ultimately, this chapter is concerned with the distinguishing of the (historical) eucharistic sign from the referential boundaries of the Biblical text. To some people this may sound heretical and contrary to the biblically given sense of the eucharist. But this objection presupposes that the biblical sense is first and foremost a referential sense. The following treatments of the bible rely on the appreciation that the bible is not primarily concerned with historical and institutional references, it arises out of celebrations of the Gospel, and the desire to learn ways of living the Good News of Christ Risen! 
Denis Farkasfalvy, has presented the view that "the narrative tradition that stands behind the Synoptics was formed and shaped in the 'eucharistic cradle' of the early Christian Liturgy."227 His theory is that the frequent Synoptic accounts of Jesus "as the one coming" (है $\rho \chi o \mu \alpha l)$ to a place and the people "approaching" 228 to meet Jesus reflect the basis on which the Synoptic narratives were formed. A post-crucifixion "audience gathered for hearing about Jesus because they wanted to meet Jesus by means of the liturgical assemblies". ${ }^{229}$ In the gatherings, the one who "both arrives and is being approached, encounters a human need or religious problem - a human situation of 'crisis' - and brings an experience of salvation." 230 "The emphasis on the "coming" of Jesus in these pericopes clearly exhibits the "maranatha" sense of the earliest liturgies. ${ }^{231}$

Interpreting the oral tradition as a tradition that invokes encounters with Jesus, Farkasfalvy wrote:

"I...claim that the way Jesus is portrayed in the literary composition of our canonical gospels - this framework of a peripatetic way of life and the fact that, episode after episode he keeps on coming and being approached as he passes from place to place - is the result of the Eucharistic setting in which the Jesus tradition was formed, chiselled into oral patterns, and finally turned into literary compositions which the early church canonized."232

On this basis Farkasfalvy claims that "the entire New Testament is of a eucharistic provenance and therefore must be interpreted in a more or less immediate eucharistic context." ${ }^{233}$ Martin's response consists of "further considerations" arising out of his "mostly corroborative" remarks. ${ }^{234}$ Their treatments bring to light the dynamics of gathering, sharing the meal and the sign of the meal, hearing a narrative about Jesus (before or during the meal) and, after sufficient prayer and celebration, departing.

The emphasis in Farkasfalvy's paper and Martin's response, is on the relation between the coming of Jesus and the approach of the people. Martin asserts "clearly such a manner of narrating embodies a faith vision of Jesus, not as an important protagonist in the past, but as

\footnotetext{
${ }^{227}$ Farkasfalvy, 34.

${ }^{228}$ Farkasfalvy, 35.

${ }^{229}$ Farkasfalvy, 34-35.

${ }^{230}$ Farkasfalvy, 35.

${ }^{231}$ Bradshaw and Johnson, 16.

${ }^{232}$ Farkasfalvy, 35-36.

${ }^{233}$ Farkasfalvy, 44.

${ }^{234}$ Martin, 55.
} 
the Lord still in the midst of his people." ${ }^{235}$ According to both commentators these gatherings provided the content and much of the form of the synoptic texts. Other New Testament texts were also formed through the meal format of these gatherings. Concerning the content of the Pauline letters Farkasfalvy writes, "the presence of liturgical formulas (greetings, prayers, blessings, fragments of hymns) are unmistakable signs that they were meant to be presented at assemblies connected with the celebration of the Eucharist" ${ }^{\text {"236. }}$.

Farkasfalvy's and Martin's treatments are convincing, although an exception may occur in relation to the Johannine readings. The absence of a eucharistic last supper in John's Gospel strongly suggests that the Johannine community at the time of the second edition of the Gospel was non-eucharistic. The absence of a eucharist at John's last supper strongly suggests that it was not until the era of the third edition of the Gospel (the fourth era - the third era being that of the epistles) that the Johaninne community became Eucharistic. Von Wahlde $^{237}$ asserts that there is no evidence concerning the Eucharist in the first edition ${ }^{238}$. This is because the second edition completely replaces the last supper texts of the first edition. However, Farkasfalvy's insights into the first edition pericopes facilitate further reflection on the question of the Eucharist in the Johannine texts. "The reference to "the one who is coming after me" on the lips of John the Baptist belongs to the oldest common elements of all the Gospels" ${ }^{, 239}$. Nor would this theory prevent theories that non-eucharistic literary developments also occurred in the history of the communities. Farkasfalvy, acknowledges a phase in which literary developments began to shape the texts. Quite often the account of the "coming" of Jesus "stands in a redactional passage or sentence containing clear marks of the evangelist, and thus seems to belong to the written form of the gospel rather than the oral tradition" 240 . However, returning to the question of transition from the ministry of Jesus to the early assemblies, Farkasfalvy's insight offers new avenues of exploration. It is especially helpful in appreciating the links between the biblical Eucharist and the traditions of Jesus. It also brings force to the view that, if there were no Eucharist, there would have been no New Testament.

\footnotetext{
${ }^{235}$ Martin, 57.

${ }^{236}$ Farkasfalvy, 28.

${ }^{237}$ Urban C von Wahlde, The Gospel and Letters of John, 3 vols.

${ }^{238}$ Von Wahlde, The Gospel and Letters of John, vol. 1, 550.

${ }^{239}$ Farkasfalvy, 38.

${ }^{240}$ Farkasfalvy, 35.
} 


\section{The Todah Meal}

Although Farkasfalvy does not refer to the Todah ${ }^{241}$ meal, it is astonishing to notice the compatibility between Farkasfalvy's accounts of the kinds of gatherings indicated by the Synoptic pericopes and Hartmut Gese's accounts of the Todah meal ${ }^{242}$.

(a) Jewish meals

Attending to the Jewish issues there are other factors to consider: Taylor and Nodet ${ }^{243}$, Farkasfalvy and many others, articulate a fairly obvious point. During the ministry of Jesus there was a tradition, or there were traditions, of liturgical meals which had an integral narrative content concerning Jesus. This narrative content would have accompanied liturgical meals prior to the crucifixion. These could have been celebrated frequently. The second factor is the role of the meal-sign. It is a tautology to say that liturgical meals involve a mealsign. Furthermore, Judaism had a rich variety of liturgical meals. We may give special attention to the Passover, Sabbath, Pentecost and Todah meals. They all figure in the early Eucharists. Nodet and Taylor note the coincidence of Pentecost and Passover elements in the Synoptic last suppers. ${ }^{244}$ The Didache calls for the celebration of the Eucharist on "the Lord's Day" $^{245}$. Gese describes the Eucharistic pertinence of the Todah meal. ${ }^{246}$ All these meals formed part of the meal tradition of Jesus. It is impossible to read the last supper scriptures and John 6 without considering all four. However, a particularly valuable insight comes through acknowledging the role of the Todah meal.

With his theory that the last supper was a Todah meal Hartmut Gese contributes exceptionally valuable research for reflection on the early Eucharists. When the attributes of the Today meal are compared with the attributes of the Eucharists that occasioned the narrative periscopes in the Gospels, some new understandings emerge about the beginnings of the Eucharistic tradition. Geese's theory about the last supper being a Today meal and

\footnotetext{
${ }^{241}$ The same upper-case lower-case convention applies to "Todah" as to "Eucharist". The generic reference is capitalised; "Todah". Particular references are lower-case, "todah".

${ }^{242}$ Gese, "The Origin of the Lord's Supper," in Essays on Biblical Theology, 117-140.

${ }^{243}$ Nodet and Taylor, The Origins of Christianity"

${ }^{244}$ The Origins of Christianity 116.

${ }^{245}$ Didache, 14.

${ }^{246}$ Gese, "The Origin of the Lord's Supper." 117-140.
} 
Farkasfalvy's theory that the Gospels were composed of many narratives about Jesus prove very compatible.

Before combining the two theories some observations need to be made about Gese's theory. Firstly, a number of facts support it. "todah" - like "eucharistia" - means "thanksgiving". 247 Therefore, Gese argues that the Greek title of the liturgical meal, "eucharistia" is a translation of the Jewish title "Todah". Secondly, the Todah meal was not celebrated in accord with prescribed calendrical dates. Thirdly, it was occasional, celebrated when someone had been delivered from an extreme trial. Fourthly, the Todah meal is a sacrificial meal in which the priest sacrifices an animal and bread. It is prescribed in Leviticus ${ }^{248}$. On these premises Gese argued that the last supper was a Todah meal. Gese described its essence: "the essential element is that the thankful acknowledgement of God is expressed in a so-called song of thanks of the individual, which refers back to the time of the troubles and 'thinks on' $(z k r)$ the deliverance and the experience of death and salvation" ${ }^{, 249}$. He also describes its practice:-

"The old todah was a sacral meal, but in practice it had been largely separated from the temple, where only the slaughter of the sacrificial animal took place. The meat was prepared in various ways for the communal celebration which was observed the same day [as the sacrifice] in the houses of Jerusalem (Zebabim V, 6). In later times bread was offered as a gift of tithe to the priests, without the necessity of the bread being present in the Temple at the time the animal was slaughtered. The killing of the sacrifice automatically sanctified the bread (Menahot VII, 3). Thus, private worship had in practice been so divorced from the Temple that only the killing of the animal took place there, and the sanctifying of the bread took place of itself through the shedding of the blood of the sacrifice." 250

The call to remembrance was also part of the Todah rubric. Further evidence that this was the New Testament model of the last supper sacrifice comes through uses of Todah psalms in the passion narratives, especially psalm $22^{251}$. "Remembering can assume special importance through recitation of the song of lament which the individual sang when in trouble and which when possible concluded with the vow of a thank offering, ...". 252

\footnotetext{
${ }^{247}$ Gese, "The Origin of the Lord's Supper," 138.

${ }^{248} \operatorname{Lv} 7: 12-14$.

${ }^{249}$ Gese, 129.

${ }^{250}$ Gese, 136.

${ }^{251}$ Cf Mk 15:34

${ }^{252}$ Gese, 129.
} 
A difference between the bread sacrifice of the last supper and that of the Todah sacrifice is that the blood sacrifice took place the day after the last supper meal, while for the Todah meal "the communal celebration... was observed the same day [as the sacrifice]." 253 However, Gese identifies the last supper as the moment when the sacrifice begins. The bread is sacrificial because Jesus offers it at a meal in which he also testifies to his impending "betrayal" ${ }^{254}$. This is his proclamation of the blood sacrifice. It establishes the occasion of the meal offering and renders the meal a sacrifice. Gese based his theory that the last supper was a Todah meal on these clear correspondences between the last supper and the account of the Todah meal in Leviticus.

(b) Gese and Fakasfalvy

It is striking to consider the compatibility of Fakasfalvy's theory with Gese's teaching on the Todah meal. That the Gospels were comprised largely of liturgical narratives structured by eucharists, fits well with Gese's argument that the last supper Eucharist was a Todah meal which may also be called a Todah sacrifice. This is enough to explain the thanksgiving emphasis in the meals of the early tradition. It also accounts for the copious demonstrations of a liturgical setting for the narrative pericopes found in the gospels. Among those many todah settings, the todah that Jesus offered concerning his own deliverance would stand supreme.

Did Jesus offer that Todah in history? This prospect is briefly explored by Rabbi David Stern and Richard Taylor in Rediscovering the Eucharist ${ }^{255}$. They treat the prospect positively, and recommend further exploration. A significant reason for their not concluding that the last supper was a todah meal is that the multitude of similarities between a Passover and a todah meal makes it impossible to say which of these kinds of meal it was ${ }^{256}$. The difficulties in resolving these issues point to the fact that however the Eucharist transpired, it has always signified as a whole that is greater than the sum of its parts. It is conceivable that the last supper narratives attributed a todah significance to the meals of Jesus, just as they also did a Passover significance. Further to these points, there is no need to be reductive in accepting the traditional formation. It is necessary to observe the contributions that the literature and traditions of the Passover, Sabbath and Pentecost meals bring to the last supper narrative. The

\footnotetext{
${ }^{253}$ Gese, 136.

${ }^{254}$ Gese, 137.

${ }^{255}$ David E. Stern, "Remembering and Redemption," 1-15. See also Richard Taylor. "A Response [to David E. Stern]", ibid., 16-26.

${ }^{256}$ Stern, "Remembering and Redemption," 11-12; Taylor, "Response," 23-25.
} 
Todah, Passover, Pentecostal, Sabbatical and even the Symposium parts of the Eucharist give clues to its meaning. For lack of the opportunity to explore all these cultural elements in themselves, it is necessary to explore the way each contributes to the new phenomenon that is the Eucharist. The most comprehensive title is the Eucharist and therefore, it is with that title, in its Jewish sense of "Todah" that this description of the temporalization of the sign begins.

If there are elements of various traditional meals, it is because the narrated meal is a synthesis. One of the many values of the Todah meal is that it allows the synthesis to be occasioned rather than seasonal or weekly, as with the Pentecost and Sabbath meals. Like the Passover meal, which is formed to celebrate an historical intervention by God, the Todah meal also responds to the element of intervention in the ministry of Jesus. Also, like the first Passover, it allows that intervention to arrive from outside the prescribed liturgical calendar. According to Exodus 3:18 Moses initially sought three days "to celebrate in the wilderness". Similarly, the ministry of Jesus and the gift of worship that he imparted, - the need to celebrate the Eucharist on a day other than the Sabbath, along with the mission among the gentiles, - all demanded a creative approach to the circumstances of the first Eucharists. The flexibility in the Todah meal would make it a valuable contributor to the liturgies of the Jewish Church.

\section{The Eucharist in Scripture}

The New Testament accounts for the meaning and existence of the eucharist through two different types of source. The most familiar is that given in the last supper accounts. The source of the eucharist is the historical Jesus. Paul refers to this as "the night he [Jesus] was handed over" ${ }^{257}$. The Synoptics situate this as the night of the Passover meal, on the eve of his death.

The other source is the "Father" of Jesus. He "gives you the true bread from heaven" 258 . The Father is not the only source. In John's Gospel, Jesus also declares himself a source of eucharistic life: "I am the living bread that has come down from heaven....and the bread that I will give is my flesh for the life of the world" ${ }^{259}$. Therefore, in both the Synoptics and John,

\footnotetext{
257 Cor 11:23.

${ }^{258}$ Jn 6:32.

259 Jn 6:51.
} 
Jesus accounts for himself as the source of the eucharist. But in the Synoptics, Jesus is a source on earth. In John, he is a source from heaven.

How then did the high Christological sense of the eucharist result from an historical progression? Once these two extremely different horizons are acknowledged, the scriptures pose a problem: "how have the earliest accounts of the eucharist come to declare such diverse origins?" Exploring this question strong evidence emerges that the high Christological sense of the eucharist resulted from an historical progression.

This point can be explored through a developmental approach. It begins with the sense that the first convivial gatherings at which the post-Easter disciples gathered to remember Jesus were low Christological gatherings. As a high Christology began to develop in these communities, their appreciation of the eucharist also took on high Christological attributes. These increasing heights of Christology are evident in the progression from Mark and Matthew's eucharists to those of Luke and ultimately John.

To appreciate this progression it is necessary to engage with the apocalyptic aspects of the last supper texts. The indicators of the progression towards a high Christological Eucharist is reflected by apocalyptic developments in the eucharistic scriptures. J.J. Collins, ${ }^{260}$ included in his early definition of apocalyptic that it "discloses a transcendent reality". ${ }^{261}$ Therefore apocalyptic references may be treated as high references. They are evident throughout the synoptic last suppers. By analysing these references and exploring their environment, it becomes possible to learn about the high Johannine references.

The apocalyptic eucharistic sayings of the last supper accounts come directly after the institution narrative in Mark and Matthew, and directly before it in Luke ${ }^{262}$. Their chronological development is easy to trace. They go from the most simple to the most complex. The increased levels of reflection and plurality of elements show a chronological process of building and re-integrating ideas, upon and among one another. The Johannine writings exhibit the same chronological process of complexification, but from within a different literary and theological environment ${ }^{263}$. Do they give a clue to the different eucharistic traditions of the New Testament Church?

\footnotetext{
${ }^{260}$ J. J. Collins, “Apocalypse: The Morphology of a Genre”, special issue, Semeia 14, 1979.

${ }^{261}$ J. J. Collins, 9.

${ }^{262}$ Mk 14:25, Mt 26:29, Lk 22:15-19.

263 "they [ the Johannine writings] have had a particularly complex origin." Von Wahlde, The Gospel and Letters of John, vol. 1, 1.
} 
(a) Mark

In the earliest Gospel account of the last supper, at the end of the institution narrative, Mark has Jesus say;

"Amen, amen I say to you I will not drink the fruit of the vine until the day that I drink it anew in the kingdom of God"264

(b) Matthew

Matthew's version is;

"... and I say to you, I will not drink from the fruit of the vine until the day when I drink it with you anew in the kingdom of my father"265

Coming, like Mark, at the end of the institution narrative, Matthew adds the element of an apocalyptic community that shares the fruit of the vine with Jesus. This development may have been contemporary with Mark's but the added element suggests both dependence and further reflection.

(c) Luke

Along with Matthew's reference to the eschatologically formed community, Luke provides several more factors contributing to the apocalyptic environing of the meal.

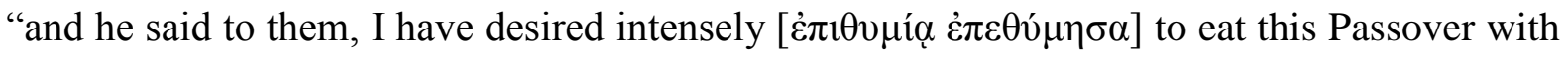
you before I suffer, for I say to you that I will not eat it again until it is fulfilled in the kingdom of God. And taking the cup of wine and giving thanks he said, take this and share it among yourselves, for I tell you, from now on, I will not drink of the fruit of the vine until the kingdom of God comes."266

Many instructive features of high and apocalyptic Christologies come to the fore in this text.

${ }^{264} \mathrm{Mk} 14: 25$

${ }^{265}$ Mt 26:29.

${ }^{266}$ Lk 22:15-19. 
First, this is a much longer apocalyptic proclamation than Mark's (30 words) or Matthew's (66 words). Second, the apocalyptic proclamation comes at the beginning of the meal. Therefore, the opening environment of the Lucan eucharist is not Jesus' historical prophecy of betrayal by Judas, but Jesus' passionate eschatological expectation of eternal fulfilment. Furthermore, the apocalyptic promise has not one, but two terms of reference - paschal food and the fruit of the vine. In addition, the promise is fulfilled in two ways: (a) in a process that goes from the earthly meal to the heavenly kingdom, for $\mathrm{He}$ "will not eat the Passover again until it is fulfilled in the Kingdom of God"; but also (b) in a process that comes from heaven to earth. He "will not drink the fruit of the vine again until the kingdom of God comes.

Another interesting feature of Luke's treatment of the Passover Meal is his inclusion of Jesus' confession of an intense eschatological desire at the meal. "With desire I have desired to eat... because I will not eat it again until it is fulfilled." Finally, in Luke's account, the statement of Jesus' desire represents the principal emotional content of the meal and directs it towards heaven. Therefore, Luke's reference to the meal changes its emphasis from an environment of betrayal (as in Mark and Matthew) to an environment that bears the promise of eschatological fulfilment. It is also changed from a prediction of an objective historical event to the confession of a subjective longing - Jesus' longing for communion with the Father, in the community of his disciples.

(d) John

Even though Luke's treatment of the eucharist is profoundly apocalyptic, it still describes the Synoptic journey through the historical gift of the last supper eucharist to the Father. John's eucharist is radically different. It is not the bread of heaven because it leads to heaven. It is the bread of heaven because it "comes down from heaven",267.

Urban C. von Wahlde's recent, milestone study of the Johannine writings has given even greater strength to the idea that the high Christological understandings of the eucharist were the fruit of decades of reflection. In his the three-edition theory of John's Gospel and its relation to the three Epistles, he makes it possible to trace a history of the Eucharist in the Johannine community.

${ }^{267}$ John 6:32. 
Firstly, he makes it clear that the place of the eucharist in the first edition is inaccessible because there is no first edition material in the last supper accounts. As for the second edition, it was a non-eucharistic document. This is evident in the lack of any eucharistic references in the last supper passages, from John 13:1-17:26. According to von Wahlde, the Second Edition emphasized the spirit to the point of sparking a movement away from devotion to Jesus, especially to the historical Jesus. The members of this movement taught that Jesus came to hand over the Spirit, and that, thanks to him, those anointed with the spirit were now being led further into the spirit, beyond the revelation of Jesus. The eucharist was not valued by this community because it was not a spiritual, but a material reality. ${ }^{268}$

Although Brown dated the Epistles after the Third Edition of the Gospel ${ }^{269}$ and von Wahlde, dated the Epistles before the Third Edition, he maintained Brown's teaching that these later Johannine writings were composed to re-establish and advance the sense of the significance of Jesus. This emphasised the high and unique sonship of Jesus in relation to the Father. ${ }^{270}$ It included a new appreciation of the historical traditions and the Eucharist. Furthermore, by this stage the writings were written with a sense of Church that went well beyond the Johannine Community. They were written with the whole Church in mind. ${ }^{271}$ Putting these notes together, the later Johannine writings exhibit an increased emphasis on the divine Sonship in the Eucharist. Along with this the Johannine communities had come to recognise themselves as part of a global Church. In this environment, the newly discovered Eucharist took on exorbitant significance.

Von Wahlde's explorations attest to the understanding that John's Gospel taught and celebrated a high Christology of the eucharist and that this took time to develop. ${ }^{272}$ The death of the Elder who wrote the Epistles, who was also the "Beloved Disciple" of the Gospels, seems to have been very influential in the Johannine turn to the Eucharist. It is also surprising to think that this may have been the communities' first valuing of the eucharist. But, however things might have transpired prior to the era of the Third Edition, the exalted references to the eucharist in John 6, show that, with the Third Edition, the place of the eucharist was now made paramount. Jesus, "the Word made Flesh" 273 was given from heaven in the eucharist -

\footnotetext{
${ }^{268}$ The Gospel and Letters, 3:3-4..

${ }^{269}$ Raymond Brown, The Epistles of John, 101.

${ }^{270}$ Von Wahlde, 1:422-23.

${ }^{271}$ Von Wahlde, 1:545-547.

${ }^{272}$ Von Wahlde, 1:395-560.

${ }^{273}$ Jn 1:15.
} 
"Just as the living father has sent me and I live because of the father, so also, that person who eats me will live because of me"274.

(e) Assessing the Scriptural Evidence

But although this evidence creates a compelling sense that a high Christological, or "bread from heaven" eucharist, was a late development in the New Testament communities, there are reasons for questioning this understanding. In the first place, Paul's apocalyptic last supper saying also has a high Christological tone: "when you eat this bread and drink this cup you proclaim the death of the Lord until he comes"275. This is significant for the theory of literary evolution, because 1 Corinthians 11:23-26 is the earliest complete passage on the eucharist. Therefore, literary evolution is not the only way that revelation occurs and it is easy to confuse literary evolution with revelatory gifting. The uses of " $\pi \alpha \rho \alpha \delta i \delta \omega \mu \imath$ " by Paul, and in the bible, propose the idea that revelation is not only in the bible. It is also alongside the bible in the processes of traditioning. Can these literary and non-literary expressions of truth be combined? The revelatory gifting belongs in all the processes of revelation; it is conceived in prayers and thoughts, it gestates through prayers, conversations, existential crises and traditional practices. Then through these processes the corresponding literary works may or may not be born. If written they can take up an especially mature place in the processes of revelatory communication.

The literary works show that significant insights have been accepted to the point that they can receive publication as literature. But how long were the significant insights alive and breathing in the traditions of the communities before they became synthesized with other insights and found their way into literary expression? Is the discernibility of an insight dependent on its writability? Or, is high Christological literature the result of insights that could be discerned but not written about? Paul, discerned sighs too deep for words ${ }^{276}$ - things which motivated the literary quest and which the literary quest would never be able to equal? This has special pertinence to the Eucharist, since before the Eucharist was accounted for in scripture, it was a traditional sign. But can anything be said about the ways the gifts of revelation preceded, or functioned somewhat independently of the chronological achievement of literary development?

\footnotetext{
274 Jn 6:57.

2751 Cor 11:26.

${ }^{276}$ Rom 8:15.
} 


\section{The Sign of Infinite Loveableness}

The sign of the Eucharist may be understood further through Psalm 22, a Todah Psalm. ${ }^{277}$ The first century Church valued this psalm greatly. It voiced the prayer of Jesus on the Cross. For Gese, the use of this Todah Psalm was further evidence that the last supper and earliest meals in the tradition of the Eucharist were Todah meals. ${ }^{278}$ Further reflection shows that the psalm gives a witness to the intercessory power of loveableness, the loveableness of the beloved who has been handed over. It also shows that the Todah meal and the Todah psalm carry the sense of an invincible inter-personal bond between the delivered one and the Lord. Through psalm 22 the final paragraphs in this chapter begin to expose this point.

The passivity of suffering pervades first two thirds of the psalm (Psalm 22.1-21a). Then suddenly it changes in to praise and thanksgiving (Psalm 22:21b-31). This is the classic structure of todah Psalms. They tell of the plight of the person who has been delivered and then praise God for the deliverance God has accomplished. Psalm 22 seems to testify to God's motive for performing this deliverance. It does so in verses $20-21$.

Verse 20, the penultimate woeful verse has the words "deliver my soul from the sword, my

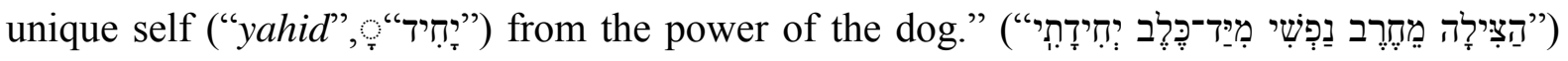
279. The following verse asks God to "save me from the lion's mouth" ${ }^{280}$. Then, the celebration of deliverance begins. "From the horns of wild bulls you have answered me"281. The unusual construction of this English translation is because of a lack of grammatical equivalents in English. The idea in the verse is that the one who calls out to be saved (vs 21a) is responded to and the relationship in this response is itself deliverance "from the horns of the wild bulls." It could read "I called to you from amidst the horns of wild bulls and you have answered me and your answering has delivered me". From that point on the psalm is full of joyful praise and thanksgiving. "I will proclaim your name to my brothers and sisters. In the midst of the assembly I will praise you". This celebration in the community, follows from a profound and unique bond with the Lord. The movement from subjective passivity to social activity is a recurring theme in reflections on the Todah meal and psalms. It also emerges as profoundly Eucharistic.

\footnotetext{
277 Gese, 133.

${ }^{278}$ Gese, 137.

${ }^{279}$ Psalm 22:20.

${ }^{280}$ Psalm 22:21a.

${ }^{281}$ Psalm 22:21b.
} 
A striking feature of these verses is the noun "יָיָיזיד" (unique self). The noun is used 3 times in the narrative for the sacrifice of Isaac (Gen 22:2, 22:12 and 22:16). There, as in psalms $25^{282}$, $35^{283}$ and $68^{284}$, it refers to the binding loveableness of the only beloved. The Septuagint translates the three uses in Genesis 22 with " $\tau$ ov $\alpha \gamma \alpha \pi \eta \tau o \tilde{v}$ ” and the uses in Psalms 22, 25 and

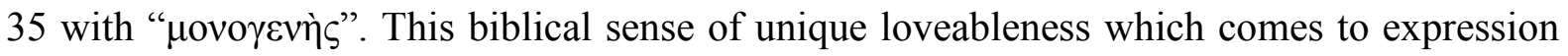
through the noun "ייָיזיד" testifies to the loveableness of the psalmist. The testimony brings a turning point in the psalm. The intimate loveableness of the psalmist becomes the reason God responds to the psalmist. The psalm expresses the moment of grace in which the psalmist prays amidst the healing revelation of his or her loveableness.

This subjective turn in the psalm is not incompatible with the general meaning of Todah psalms and meals. Gese notes that Psalm 51, a Todah psalm, does not achieve its turning point on the basis of an external sacrifice, but the gift of "a broken spirit and a humble contrite heart" ${ }^{285}$. This indicates the subjective character of the Todah meal. It concerns the intimacy between the Lord and the celebrant of the meal, an intimacy that is deepened by the subject's passivity of suffering.

Many New Testament texts develop this subjective spirituality and apply it to Jesus at his baptism. As described above ${ }^{286}$, the loveableness of Jesus, celebrated in the sacraments also testifies, through the sacraments, to the loveableness of the disciple. It reveals the heart of prayer. Psalm 22:20-21 suggests that the reason for prayer's effectiveness is the irresistible loveableness before God, of the one who prays.

This emphasis on loveableness and the relationship of intimate love between God and the one who prays is also expressed in Paul's allusion to Abraham's offering of Isaac. In Romans

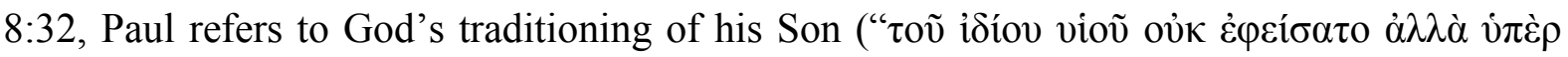

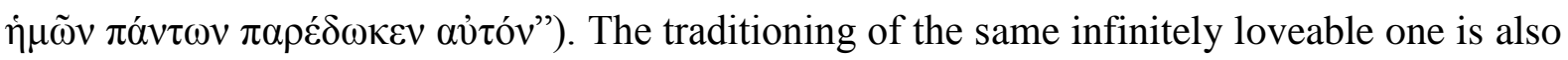
communicated by Paul in Galatians 2:20 and in 1 Corinthians 11:23. In the latter of these verses, $\pi \alpha \rho \alpha \delta i \delta \omega \mu \imath$ occurs twice, once when Paul refers to his traditioning of the sacrament ${ }^{287}$ and once in reference to Jesus being betrayed ${ }^{288}$. Paul's traditioning (in the active voice) and

\footnotetext{
${ }^{282}$ Psalm 25:16.

${ }^{283}$ Psalm 35:17.

${ }^{284}$ Psalm 68:6.

${ }^{285}$ Psalm 51:17; Gese 133 - "The sacrifice of thanksgiving is transformed into an inward sacrifice of one's own life."

${ }^{286}$ Cf above, chap. 1, part A, section 2, (d), (ii), p. 66-7.

${ }^{287} 1$ Cor 11:23a.

2881 Cor 11:23b.
} 
the traditioning of Jesus (in the passive voice) have this in common, they are both prayerful expressions of traditioning. Hebrews says of Jesus, "he prayed in tears with such humility that the Lord heard him." ${ }^{289}$ This reflects the prayer of the one who has been handed over. In using the word $\pi \alpha \rho \alpha \delta i \delta \omega \mu l$ twice in the one verse Paul shows that he and the Lord Jesus are united in the one offering of prayer. This unity in the offering of prayer has been provided by the gift of Jesus who allows himself to be traditioned as a gift of prayer.

The following chapter will continue to explore the gift of the Eucharist as an expression of prayerful traditioning and of an identified tradition.

${ }^{289}$ Heb 5:7 


\section{Chapter Two}

\section{Approaching the Eucharists of the Metaphysical Traditions}

“La corrélation du Dire et du dit, c'est-à-dire la substitution du Dire au dit, au système linguistique et à l'ontologie est le prix que demande la manifestation."

- Emmanuel Levinas ${ }^{290}$

\section{Introduction}

This chapter describes the developing loss of distinction between the senses of identity and relationship in the Eucharist. The chapter is in two parts. Part A begins by exploring relational signification in the earliest post-apostolic descriptions of the Eucharist, found at the end of John's Gospel. Part B explores the fact that, by the middle of the third century, the "traditioning" of the Eucharist had been nominalized and called "the tradition of the Lord" $(\text { Cyprian })^{291}$. It argues that since then, nominalization and its incumbent emphasis on identity has gradually overwhelmed the relational and verbal senses of the Eucharist and eucharistic traditioning. Because Thomas Aquinas has such a comprehensive approach to the tradition of the Eucharist the chapter concludes with some brief comments on the senses of relationship and identity in his "Adoro Te Devote".

\footnotetext{
${ }^{290}$ Emmanuel Levinas, Autrement qu'être ou au-delà de l'essence. Paris: Kluwer Academic, 1990, 17.

${ }^{291}$ Cyprian, "Epistle LXII: To Caecilius, on the Sacrament Cup of the Lord", 2; hereafter referred to as "Epistle LXII" - Latin title is Cyprian, "Epistula LXIII: Cyprianus Caecilio Pratris". Source hereafter referred to as "Epistula LXIII". Although numbered differently (LXII in the English, LXIII in the Latin), these two texts are the same letter to Caecilius of Bilthra. The different numbering in the English (ANF) and Latin (CSCO) editions of Cyprian's writings is due to Ad Donatum being included as Epistle I in the latter.
} 


\section{Relationship and Identity in the Eucharist}

The chapter is concerned with the historical expression of the distinction between relationality and identity in the Eucharist. The connections between relationship and identity pervade the entire history of the sacrament. However, a general history cannot get to grips with that topic. It is not a matter that emerges in ongoing ways within a defined period of history. Rather, it is a decisive matter which having arrived and had its effect, might never emerge again. It has already defined the parameters within which the subsequent history will develop and be thought. The task is to examine those defining moments. Once they have been discovered and explored it becomes possible to rethink and reapply the issues of relationship and identity that had been overlooked in the past. But the interconnections are problematic, their exploration is challenging. The sense of relationship and unconditional loveableness that the Eucharist expresses has often been concealed and underprivileged by the sense of identity to which the Eucharist has been bound.

This proposed re-emphasis on relationality does not mean the exclusion of identity. The critique of the imposition of identity and nominalized priorities cannot dispense with issues of identity. Identity is indispensable in the meaning of the Eucharist. However, a phenomenological reflection on identity and relationship must relegate or reduce the sovereignty of identity, so that the description of relationship is not based on the sense of identity but on the sense of relationship. A further point is that, through relationship the significance of identity is altered and augmented. The work of discerning the value of the identity will be undertaken in the next chapter. This chapter undertakes to examine two decisive times in the history of the Eucharist: one in which the relational sense of the Eucharist was clearly distinguishable from its identity, and another in which the identity of the Eucharist became severed from some of its relational elements. Identity then began to dominate the relational sense of the Eucharist.

\section{Clarifying the Distinction with a Parable}

The history of the distinction between identity and relationship may be clarified through the simile of a tapestry. The images of a tapestry can be likened to the expressions of identity that the tradition forms. The threads may be likened to the relationships that form that tradition. In its beginning stages, only the threads may be perceived - the image has not appeared yet. Similarly, when an historian looks back on the first two centuries of the Eucharist, the 
relationships that formed it are evident, but the identity of the Eucharist is in many ways indiscernible. Once its identity appears clearly in Cyprian's Epistle to Caecilius of Bilthra, it becomes possible to trace back through the lines of development that lead to that point. But approaching things from the beginning, it is probably impossible to be clear about how things developed.

The metaphor of a tapestry is also helpful in displaying the dominating propensities in identity. Someone observing the creation of a tapestry will begin to see the image develop. From that point on, interest in the threads diminishes and interest in the images increases. Similarly, within the history of the Eucharist, once the identity of the Eucharist became established, the relational concerns of the tradition were strongly orientated to maintaining a sense of the identity of the tradition.

\section{Decisive Moments in the Formative Eras}

In the history of the Eucharist, the effect of its most formative moments have lasted for the remainder of the tradition. The first of these was the life, death and resurrection of Jesus. It introduced and established the apostolic era, which was explored in the previous chapter. The second was the immediate post-apostolic era, which will be explored in part A of this chapter. The third was the era of the historically identified Eucharist. Part B explores the establishment of the Eucharist's historical identity, as articulated in Cyprian's letter to Caecillius.

The last chapter of John's Gospel shows that it was written in response to the death of the last apostle. Through this text the Eucharist emerges as the last surviving witness to the era of Jesus. Not only that, the thoroughly Eucharistic verses of John's Gospel reveal that the death of the "disciple whom Jesus loved", the last living apostle, was unexpected ${ }^{292}$. John's Gospel is remarkable because it testifies to this immediate post-apostolic crisis. Here the Eucharist receives a new emphasis. It arises not only as a testimony to Jesus, but to the most esteemed disciple's relationship with Jesus in the Eucharist. This relationship has continued without ceasing as a priority in the Eucharistic traditions. It is a sign that still signifies after the identities who established it have died.

${ }^{292}$ There was a rumour that "he would not die", Jn 21:23. 
The second formative moment was discerned and promoted through the Episcopacy of Cyprian of Carthage. He identified the Eucharist as "the tradition of the Lord". ${ }^{293}$ Through time the form of Eucharistic identity began to clarify. By the middle of the third century it had become identifiable, and Cyprian identified it as "the tradition" established by Jesus at the last supper. Cyprian's argument was clear and it provided the defining sense of the Eucharist in perpetuity. "In offering the chalice the tradition of the Lord must be observed." 294 This requires the imitation of the last supper practice of Jesus, his "accepting the chalice shortly before his passion". 295

\section{The Profound and Enduring Influence of these Texts}

John's Gospel emphasizes the relational depth of the Eucharist by basing his references to the Eucharist in the person of Jesus. Therefore, a Johannine account of the history of the Eucharist does not begin with the last supper but with the eucharistic attributes of Jesus. He is "the bread of life" ${ }^{, 96}$ given by his father in heaven ${ }^{297}$. These attributes clearly pre-date the last supper. Very early in John's Gospel a Eucharistic characteristic of Jesus is announced by John the Baptist. Jesus is "the lamb of God"298. This also puts the formation of the eucharist, not in the last supper itself, but in the person Jesus. According to John's Gospel he was designated "lamb of God" before there was any awareness that his death would occur, some years later, at the end of the Passover week.

This thesis argues that these biblical articulations of the loveableness of Jesus designate the most formative characteristic of the Eucharist. The historical beginnings of the Eucharist receive only partial testimony through the last supper accounts. To discover the sense of the Eucharist it is necessary to include, but also go deeper than the last supper narratives. It is necessary to explore the significance of the person who is the bread of life and the lamb of God. Exploring the Eucharist as an expression of Jesus forms a bond already expressed in John's Gospel: the bond between the Word made flesh and the Eucharist. When John's Gospel refers to the Eucharist as "the true bread come down from heaven", 299 it places the

\footnotetext{
${ }^{293}$ Cyprian, "Epistle LXII", 2.

${ }^{294}$ Cyprian, "Epistle LXII", 2.

295 "Calicem...sub die passionis accipiens" Cyprian, Epistula LXIII, 9.

${ }^{296}$ Jn 6:35.

297 Jn 6:32-33.

298 Jn $1: 29,36$.

299 John 6:32.
} 
origins of the Eucharist in eternity. This eternal depth of the Eucharist was not expressed in the first two editions of the Gospel, but it clearly structures the third edition, the postapostolic edition. It also informs the remaining history of the Eucharist.

In coming to appreciate the Eucharist it is necessary to explore the fact that the first sacramental step towards the Eucharist is not the reception of the Eucharist but Baptism. Baptism celebrates the disciple's disposition towards Eucharist, as it did Jesus' disposition towards the paschal events ending his life ${ }^{300}$. The Synoptics offer the baptismal witness of John through his ministry of baptizing Jesus. It was in his baptism that the loveableness of Jesus was revealed. He is God's Son. John's Gospel does not offer the same baptismal testimony, but again the designation "lamb of God" witnesses to his defining loveableness. It was because of this gifting that the disciples of John the Baptist, "Andrew and another disciple" ${ }^{301}$ followed him and began learning how to "dwell" 302 with him. From this point on, the sense of the Eucharist as a place of eternal dwelling with Jesus has sustained its meaning and practice.

The influence of Cyprian's Epistle to Caecillius has also been profound and enduring. It was in the middle of the third century that Cyprian defined the last supper in terms of "the tradition" of "the sacrifice of the passion of the Lord". 303 "In offering the chalice the tradition of the Lord must be observed." ${ }^{304}$ In a recent essay Pierre-Maurice Bogaert has shown that an expression found in this epistle, "sub dies passionis", 305 was included in early African Eucharistic prayers. This shows the influence of Cyprian's Epistle on the tradition's canonical understanding of the Eucharist. Since then different understandings of the legacy have developed. But on one point in particular, nothing has changed since Cyprian: the Eucharist is a last supper mimesis. It is the liturgical testimony to the death and resurrection of Jesus.

The following quote from Zwingli shows that the founders of the Reformation sustained this same legacy:

"The way Christ instituted the Supper: ... 'On the night in which He was betrayed and given up to death, Jesus took bread: and when he had given thanks, he broke it, and said, take, eat;

\footnotetext{
${ }^{300} \mathrm{Cf}$ above, chap. 1, part A, section 2, (d), (ii), p. 66.

301 Jn $1: 35$.

${ }^{302}$ Jn 1:38-40.

${ }^{303}$ Cyprian, "Epistula LXIII", para. 14.

304 "Epistle LXII", para. 2.

${ }^{305}$ Pierre-Maurice Bogaert, "Sub die passionis," 5-15.
} 
this is my body: do this in remembrance of me. After the same manner also, he took the cup after supper, said thanks, and gave it to them, saying, Drink ye all of this...",306

After Cyprian, it is possible to look back on this quote and argue that Zwingli is not referring to Cyprian, he is quoting 1 Cor 11:23-25. Zwingli says nothing about the metaphysical relationship between the Eucharist and the death and resurrection of Jesus, but the quote does testify that for him some kind of relationship, metaphysical or not, obtains between the supper and the death and resurrection of Jesus. But also, he is quoting Paul in accordance with Cyprian's nominal adaptation (traditio) of Paul's traditioning $(\pi \alpha \rho \alpha \delta i \delta \omega \mu l)$. Until the present day the divergent traditions and debates continue. But the issues for these debates were already established by Cyprian. He defined the celebration of the Eucharist as the imitation of the practice of Jesus at the Synoptic and Pauline "last suppers". It is the imitation of his sacrifice. This had been - and continues to be - established as the tradition of the Lord.

The structure of the chapter is formed by the sense that these first and third century developments have an influence that outweighs all their successors. Accordingly, the greatest attention has been given to the initial developments they expose. Other developments such as the Carolingian Controversy, the Reformation and Counter-Reformation, Ecumenism and the liturgical reforms of the last hundred years are important developments. They require attention, but this thesis takes the view that these later developments are served best by gaining a firm appreciation of the unresolved problems out of which they emerged. Those problems are the nominalization of eucharistic traditioning and the de-emphasis of its relational sense for the sake of its denominated identity. As the Eucharist enters its third millennium, a deeper appreciation of the relational sense of the sign may even restore some sense of its beginnings, prior to nominalization.

\section{Part A: Eucharistic Traditioning in John's Gospel}

This first part of chapter 2 describes how the Third author ${ }^{307}$ of John's Gospel communicated the meaning of the Eucharist for the first disciples of the post-apostolic era. It shows that eucharistic traditioning was not only pragmatic. It was also intimately personal and spiritual.

\footnotetext{
${ }^{306}$ Zwingli, Action oder Bruch des Nachtmahls, quoted in Bradshaw and Johnson, Eucharistic Liturgies, 262263.

${ }^{307}$ In this thesis the "Third Author" is also referred to as "the Evangelist", and "The Third Edition" as "the

Gospel". The basis for the three author theory is given by Von Wahlde. Urban C Von Wahlde, The Gospel and Letters of John, 1:10-12.
} 
The sense of " $\pi \alpha \rho \alpha \delta i \delta \omega \mu l$ ", which means both traditioning and betraying, involves the most powerful sensibilities $^{308}$. These sensibilities are expressed in the Johannine treatments of the last supper. The last supper texts reveal the Beloved Disciple's intimate relationship with Jesus.

However, before going further something needs to be said about the identity of the Beloved Disciple. In this thesis, the Beloved Disciple is not generally called "John". This is for the sake of adhering to the text and no objection to the name "John" is meant by this practice. There is traditional evidence for calling him John and there is no historical evidence to contradict this traditional evidence. Therefore, there is a reasonable probability that the Elder of the Epistles, who is also the Beloved Disciple of the Gospel, was John. It is difficult to imagine, though not impossible, that such a renowned figure would have no other name than his self-designated "Elder" 309 or the anonymous "disciple whom Jesus loved"310.

The following exegesis relies on the idea that the term "the disciple whom Jesus loved" " is intentionally symbolic and that this has a structural impact on the gospel. His title invites the reader to dwell in the same kind of relationship that the Beloved Disciple has with Jesus in the Eucharist. This renders the Gospel a revelation of intimate discipleship as well as of the human-divine gift of Jesus.

\section{The Eucharist at the Beginning of the Post-apostolic Era}

(a) A Post-apostolic Scripture

The post-apostolic era and the post-biblical era do not quite coincide. The last Gospel describes the death of the last apostle. Therefore, just as the earlier apostolic writings and Gospels had heralded the way for the community, after the death of Jesus, now John's text heralds the way for the community after the death of Jesus' most intimate apostolic companion of Jesus.

It is necessary to pause a moment and be touched by the bereavement in this community. They believed that "he would not die" 311 . Now, after guiding them for more than 50 years he

\footnotetext{
${ }^{308}$ Gese, "The Origin of the Lord's Supper," in Essays on Biblical Theology, 137.

3092 Jn 1.1.

${ }^{310}$ On the identity of the Beloved Disciple see Von Wahlde, The Gospel and Letters of John, 3:423-34.

311 Jn 21:23.
} 
has died ${ }^{312}$ ! What does the Gospel mean if this witness to eternal communion with God has died? How can the Church survive?

"He [Jesus] did not say he [the Beloved Disciple] would not die. But "if he is to dwell until I come, what is that to you [Peter]"' John 21:23. With these words a crucial element in composition of the third and final edition John's Gospel appears. It is the Beloved Disciple's death and the question of the community's survival that precipitated the composition of the Third Edition of the Gospel of John ${ }^{313}$. Therefore, John's Gospel gives us an insight into the initial steps of the post-apostolic community. It offers the first and most authoritative revelation about the post-apostolic Eucharist. It shows how profoundly the post-apostolic response is shaped by the Eucharist. At one time, the Eucharist was less important in the Johannine than in any other known community ${ }^{314}$. Suddenly, it takes on the greatest importance. In his commitment to the future of the Church the author of the Fourth Gospel places the eucharistic legacy of the Beloved Disciple at the basis of the Church's future.

\section{(b) An Intergenerational Transition}

In portraying the transition through grief to the future, the final scene of the Gospel resembles the final scene in the life of Moses. There Moses shares his vision and testimony concerning the Promised Land for the coming generations ${ }^{315}$. That scene concerns not only Moses' death, but also provision for the people who are now bereaved of Moses. There, Joshua, son of Nun, takes over the leadership of Moses. In the final passage from John's Gospel, the situation is different. The Beloved Disciple is a Joshua figure rather than a Moses figure. The tradition has already established that Jesus is the Moses figure ${ }^{316}$. He is the Risen Lord, who maintains the tradition through his ongoing, inspiring companionship. But who can take over from this Joshua? And who can take over from the Beloved Disciple? The author of the third edition emphasises the Beloved Disciple's bond with Jesus and the other disciples in the Eucharist. As a witness to this abiding companionship he has also provided the Eucharist.

A distinctive gift of inter-generational hope pervades these texts. At the heart of the biblical narrative of the death of Moses is a teaching about the intimacy of God and Moses. A

\footnotetext{
${ }^{312}$ Von Wahlde gives between 80 and 90 C.E. for the death of the Beloved Disciple. The Gospel and Letters, $1: 53$.

${ }^{313}$ The Gospel and Letters, 2:905-906.

${ }^{314}$ The Gospel and Letters, 1:550.

${ }^{315}$ Dt 34:4-5.

${ }^{316}$ The Gospel and Letters, 1:102.
} 
Rabbinic reading of Deut. 34:4-5 teaches that the words "Moses died on the mouth of the Lord" should be read "Moses died in the kiss of God"317. Also, the Septuagint refers to Moses

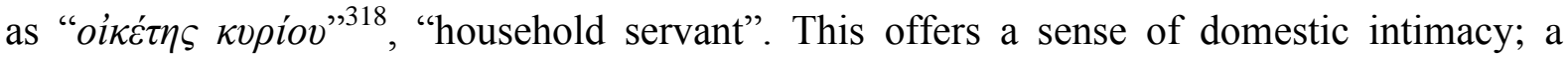
companion worthy to dwell in the house of the Lord. The intergenerational witness to the intimacy of the Lord is endorsed by the reference to the household dwelling. In John's Gospel the Eucharist, a household meal, is marked by expressions of Jesus intimate union with the Father and with his disciples. Furthermore, the intimacy of the disciple with Jesus and God consists in the disciple making God's word his or her home.

Augustine drew on the resemblances between the Johannine text and the death of Moses ${ }^{319}$. It is not necessary to argue for a deliberate textual foundation - the foundations are already provided by the historical practice of traditioning from one generation to the next. These transitions are almost universally clothed with appeals to intimacy. The appeal to intimacy is

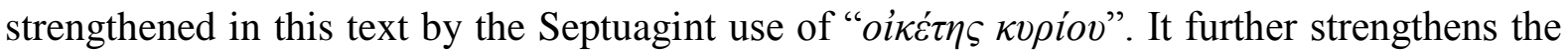
allusion to the Beloved Disciple who makes God's performative word his home and dwells in it. The evangelist testifies that the Beloved Disciple "dwells" $(\mu \varepsilon \dot{\varepsilon} \varepsilon \imath v)^{320}$ in the word of God. In addition to Augustine's observations, it must be recognised that the last Johannine author sustains the traditioning of Jesus and the Beloved Disciple by emphasizing their intimacy in the Eucharist.

The Eucharist is so important in the witness of the Beloved Disciple that the gospel concludes

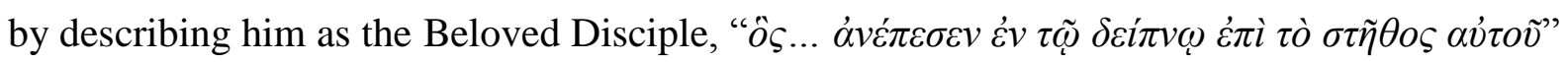
- "who rested on the side of Jesus at the supper" ${ }^{321}$. The bond is emphasized again when the Beloved Disciple's practice of "dwelling until Jesus comes" is repeated in verses 22 and $23^{322}$. This final scene displays three abiding features of the Eucharist: the journey towards Jesus and God in the witness of Peter, the journey towards the disciple in the coming of Jesus, and the dwelling in Jesus in the Eucharistic practice of the Beloved Disciple. This is the last word of the biblical narrative. The remaining two verses are the author's conclusion.

\footnotetext{
${ }^{317}$ See Levinas, Autrement qu'être, note 1, 278.

${ }^{318}$ Dt. 34:5.

${ }^{319}$ Augustine, Tractates, 124.

${ }^{320}$ Jn 21:22.

321 Jn 21:20.

322 Jn 21:22-23.
} 
(c) From the End to the Beginning

A theme that this thesis cannot avoid is the sense that the meanings of the beginnings are clarified by examining their ends. This is very evident in the Third, - i.e. final and canonical Edition of the Fourth Gospel. At the end of the Gospel, the third edition shows its response to the death of the last apostle but the shockwaves reverberate through and transform the entire Gospel. Not only the death of the Beloved Disciple, but also the deaths of Jesus and Peter dominate the end of the Gospel. Furthermore, links show themselves between the end of the Gospel and the last supper account in John 13. But it is the encounter with these deaths that pervades and transforms John's Gospel. However, the end is only the beginning. It opens the way into the depths of John's Gospel. Once these last verses have been explored it becomes possible to learn the sense of the Third Edition's passages on the Eucharist, passages that are post-apostolic.

\section{The Journey into the Johannine Eucharist.}

(a)The Post-apostolic Era and the Deeper Meanings of the Gospel.

This exploration of the post-apostolic meaning of the Eucharist starts with the final eucharistic references of John's Gospel. ${ }^{323}$ They discuss the deaths and ultimate ministries of the arch-apostles Peter and the Beloved Disciple. They expose core ingredients of the text, and render several earlier chapters of the Gospel easier to understand. These earlier passages of the Gospel were also compiled, and in some cases written, after the death of the Beloved Disciple. Many of their key ingredients will be discussed in the pages ahead but the final title given to the Beloved Disciple captures the structure and sense of exemplary discipleship in the Gospel.

Turning to the last supper account in John 13, it is evident that the Beloved Disciple has witnessed two things at the last supper. Firstly, while resting "in the bosom of Jesus" $" 324$ he has witnessed the revelation of the Divine Name "I AM"325. Secondly, he has witnessed the revelation of the betrayer ${ }^{326}$. Therefore, he has heard a prophesy that Jesus overcomes betrayal through the revelation of his name.

\footnotetext{
323 Jn 21:15-23.

${ }^{324}$ Jn 13:23.

325 Jn 13:19.

326 Jn 13:23-26.
} 
Overcoming the betrayal ${ }^{327}$ in traditioning is imperative for the author of the Gospel. He himself witnessed the handing over of Jesus, the handing over of the Spirit, and he witnessed these things as the one who was closest to Jesus, at his side in the supper and at the foot of the Cross. He and the third Evangelist had a concern that traditioning the Gospel would be in accord with the Beloved Disciple's profound and learned relationship with Jesus. The deepest and most revealing moments in this relationship are exhibited in texts that this author has decided to call "the five side scriptures." They pulsate through the structure of the Gospel.

(b) Introducing the Side Scriptures

The side scriptures are John 1:18, 13:23;13:25 19:34 and 21:20. These are the five side scriptures which directly involve Jesus. There are three words used for "side" in these verses.

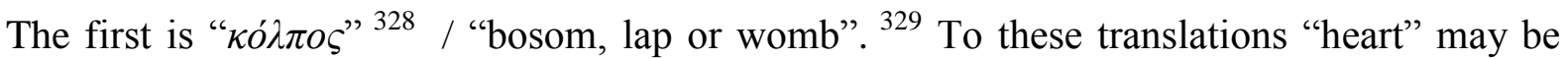
added. It occurs in John 1:18 and 13:23. It doesn't seem possible to find a comprehensive substitute in English. This author has settled on "bosom". For its third definition, Collins English Dictionary, online, defines "bosom" as "the breast regarded as the source of emotions or the seat of the inmost thoughts",330 "Lap" and "womb" refer to emotionally significant parts of the body that are not included in "breast". On the other hand "heart" although it is less in accord with the anatomical sense of " $\kappa o ́ \lambda \pi o \varsigma$ ", "also refers to the seat of emotional thought, therefore, at times it may also be used. The second noun for "side", in John's Gospel, is " $\sigma \tau \tilde{\eta} \theta o \varsigma$ " - "breast or chest"; found in John 13:25 and 21:20. It has less reference than " $\kappa o ́ \lambda \pi o \varsigma$ ", to the idea of a dwelling place for the emotions. The third is " $\pi \lambda \varepsilon v \rho \alpha{ }^{\prime \prime 331}$ : literally "rib" which also came to mean, "side". It occurs in John 19:34.

Turning to the individual scriptures, the first of these concerns "the bosom of the Father" "into" which Jesus is ${ }^{332}$. Three others concern "the bosom of Jesus in which," - or "the breast of Jesus" on which the Beloved Disciple rested ${ }^{333}$. The fifth concerns the side of Jesus from

\footnotetext{
327 “ $\pi \alpha \rho \alpha \delta \omega ́ \sigma \varepsilon l ”$ Jn 13:21.

${ }^{328}$ Jn 1:18 and 13:23.

${ }^{329}$ Cf Jean Vanier. Drawn into the Mystery of Jesus though the Gospel of John. St Paul's University: Novalis, $2004,15$.

${ }^{330} \mathrm{https}$ ://www.collinsdictionary.com/us/dictionary/english/bosom, 9/8/18.

331 “ $\pi \lambda \varepsilon v \rho \alpha ́$ pleurá, plyoo-rah'; of uncertain affinity; a rib, i.e. (by extension) side: - side," Strong, Concordance, G4125.

332 Jn 1:18.

${ }^{333}$ Jn 13:23, 25 and 21:20.
} 
which "blood and water poured out" ${ }^{334}$. All these texts have a strong reference to the Eucharist, and they have a profound impact on the structure of the Gospel. Because of their structural relationships they cannot be understood as a series that goes from start to finish. They refer back and forwards to each other. The greater depths and less accessible meanings of the earlier side scriptures become more thinkable through their relationships with the later side scriptures.

The structural significance of the texts needs to be explained. Von Wahlde's finding is that the eucharistic theology in the Gospel is the work of the its Third Author ${ }^{335}$. Therefore, the Third Author contributes the side texts. Von Wahlde has also shown that the Third Author accepts rather than alters the structure of the text. ${ }^{336}$ Therefore, the side scriptures do not form new parts to the text. Rather, they invade crucial structural points and spread their influence through the entire text. These crucial structural points are not difficult to grasp. They are the centre, beginning and end of the Gospel. At the centre of the Gospel the Beloved Disciple "rests in the bosom" 337 or "on the side of Jesus". 338 At the beginning of the Gospel Jesus is "in and towards ("عiৎ" plus the accusative) the bosom of the Father". ${ }^{339}$ At the end of the Gospel the Beloved Disciple "rests on the side of Jesus at the supper" ${ }^{340}$. Thereby, these texts turn what was once a non-Eucharistic Gospel into the most Eucharistic of all the Gospels. The imagery is very clear, life flows through the course of the Gospel, from the bosom of the Father in eternity, to the bosom of Jesus at the Supper, to the Beloved disciple "at the supper". However, a problem remains, unlike Jesus and the Father, the Beloved Disciple is a historically defined man. He cannot provide the bosom of eternity in which his disciples might rest. But through the fifth of the side scriptures he can show forth the sacramental bond that binds into history, the eternal depths of the union between the Father and Jesus.

The fifth of the side scriptures, "immediately blood and water flowed from his side", 341 refers to the historical death of Jesus. But it does so in such a way that its overflowing significance is witnessed by the Beloved Disciple and passed on by him, ("his witness is true"342). His witness, at the side of Jesus, enables him to pass on the testimony of blood and water through

\footnotetext{
334 Jn 19:34.

${ }^{335}$ Von Wahlde, The Gospel and Letters of John, vol. 1, 555-560.

${ }^{336}$ Von Wahlde, The Gospel and Letters of John, vol. 1, 357.

337 Jn 13:23.

338 Jn 13:25.

${ }^{339}$ Jn 1:18.

${ }^{340}$ Jn 21:20.

341 Jn 19:34.

${ }^{342}$ Jn 19:35.
} 
the legacy of the Eucharist and Baptism, provided in these symbols. The gift of the Beloved Disciple at the supper and the foot of the Cross, focused on the side of Jesus, provides the sacramental bond between the Father's bosom, the side of Jesus and the river of life that flows eternally through him and through the Gospel. The third author of the Gospel, shares how the Beloved Disciple remained and bore witness at the side of Jesus. Thanks to the text of the Gospel and the traditioning of the Eucharist, he provides the post-apostolic Church with a connection to the very side in which the Beloved Disciple rested and beneath which he stood. That side is rendered sacramentally available by "the word made flesh," "in the supper".

(c) The Significance of the 3 "Side" Words and the 5 "Side" Texts

(i) "кó $\lambda \pi 0 \varsigma$ " / "Bosom/Lap/Womb"

The first occurrence of " $\kappa o ́ \lambda \pi o \varsigma$ " is in John 1:18: It refers to the bosom, lap or womb of the Father. "No one has seen God, but the only Son who is towards and in the Father's bosom

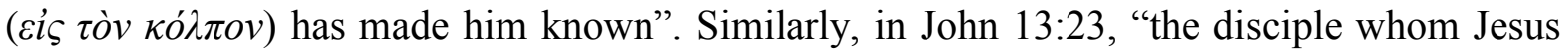
loved was reclining in the lap $(\dot{\varepsilon} v \tau \tilde{\omega} \kappa o ́ \lambda \pi \omega)^{343}$ of Jesus. This author has a strong commitment to the idea that the two uses of " $\kappa o ́ \lambda \pi o \varsigma$ " are closely related. This not only concerns their meaning, there is also structural significance in the placements of the noun. ${ }^{344}$

However, the theory, that these two uses of the same noun is significant, needs to be established in opposition to De La Potterie's analysis of the relationship. ${ }^{345}$ He disagrees with the idea of an intentional correspondence between " $\kappa o ́ \lambda \pi o \varsigma$ " in 1:18 and 13:23" ${ }^{346}$. His argument is that there cannot be a correspondence because "ci $\varsigma$ " with the accusative, in 1:18, differs too significantly from " $\varepsilon v$ " with the dative, in 13:23. However, this author's position is that the difference between the prepositions is not sufficient to undo the correspondences between the nouns. Both uses arise in the environment of a high Trinitarian Christology. The reference to the Son's being "in ( $\varepsilon i \varsigma)$ the Father's bosom" occurs in the prologue. The reference to the Beloved Disciple's being "in $(\dot{\varepsilon} v)$ the Son's bosom" occurs almost immediately after Jesus has made a pivotal "I AM" statement ${ }^{347}$ and has given the Gospel's

\footnotetext{
343 Jn 13:23.

${ }^{344}$ Cf. below, chap. 2, part A, section 2, (c), (ii), p. 109.

${ }^{345}$ See de la Potterie, La vérité dans saint Jean, 1: 229-235.

${ }^{346}$ See de la Potterie, La vérité dans saint Jean, 1: 229-235.

347 Jn 13:19.
} 
most explicit statement of the intimate unity of the Father, the Son and the Apostle in the mission of the Gospel. "Whoever receives the one I send receives me, whoever receives me receives the one who sent me." 348 A further correspondence is that both the Son and the Beloved Disciple receive exclusive and intimate knowledge from their other party, Jesus from the Father and the Beloved Disciple from Jesus. Other correlations will emerge in the course of the discussions.

However, having made these observations, it is still necessary to engage with the point of De La Potterie's critique. Why do the prepositions differ? "ci $\varsigma$ " with the accusative means "motion towards." "\&ैv" with the dative, means "being located in". This difference does not impact on the question about the corresponding uses of the noun. The prepositions express the inevitable difference between the way the Son dwells in the Father and the way the Beloved Disciple dwells in the Son. " $\varepsilon i \varsigma$ " with the accusative expresses motion towards, " $\dot{\varepsilon} v$ " with the dative expresses being positioned within. The Son of God freely and eternally journeys into ( $\varepsilon i \varsigma)$ the intimacy of Father. The Beloved Disciple cannot possibly envisage approaching the intimacy of Jesus with the Father. But that intimacy can approach him. Therefore, by "grace" 349 the Beloved Disciple is endowed with the divine intimacy that inhabits the bosom of Jesus. Through this grace the Beloved Disciple rests in $(\dot{\varepsilon} v)$ the intimacy of the Son.

The Gospel provides many passages which articulate the disciples' involvement in the intimacy the Father shares with the Son. Chapter 17 expresses it constantly. It concludes with a verse that almost mirrors John 1:18. "Father I have made your name known to them [those you have given me] and will continue to make it known so that the love with which you loved me may be in them and so that I may be in them". ${ }^{350}$ But the bestowal, on the disciples, of the most secret intimacy between the Father and the Son, is unequivocally expressed through a combination of the third and the fifth promises that Jesus makes concerning his Spirit. ${ }^{351}$

In the third promise Jesus says of "the spirit of truth" that he "will send him from the Father" and that "he proceeds from the Father". ${ }^{352}$ But in the fifth promise, in John 16:14, Jesus says, "he will take from what is mine and communicate it ( $\dot{\alpha} v \alpha \gamma \gamma \varepsilon \hat{\varepsilon} \lambda \lambda \omega)$ to you." 353 There seems to

\footnotetext{
348 Jn 13:20.

349 Jn 1:16.

${ }^{350}$ Jn 17:26.

${ }^{351}$ Jn $15: 26-27$ and $16: 12-15$.

352 Jn 15:26.

353 Jn 16:14.
} 
be a conflict. The Spirit comes "from the Father" but he "takes from" what belongs to Jesus. This slightly confuses the question about where the Spirit comes from. The Spirit seems to come from the Father and from Jesus? John 16:15 shows that he comes from both and he takes from what they share. "Everything the Father has is mine. That is why I said that he will take from what is mine and communicate it to you." 354 This text verifies that the Gospel articulates the idea that the exalted intimacy between the Father and the Son is communicated to disciples. This strengthens the understanding presented in this discussion, that " $\kappa o ́ \lambda \pi o \varsigma$ " is used in John 1:18 and John 13:23 to communicate the idea that the Beloved Disciple's intimacy with Jesus at the Supper, also involves his receiving a unique intimacy from Jesus. The Beloved Disciple receives a part in the intimacy Jesus has with the Father. This understanding is substantiated further by the singularly clear statement of traditionally communicated intimacy, given at the last supper. In John 13:20 Jesus says, "Whoever receives the one I send receives me, and who ever receives me receives the one who sent me." 355 This verse concerns the handing on of intimacy between the Father and the Son, to the Beloved Disciple at the Supper. It also concerns the handing on of that intimacy from the Beloved Disciple to the one to whom the Beloved Disciple is sent. This is the dynamic model of post-apostolic traditioning that the author of the Third Edition communicates through the Gospel. At its heart is his post-apostolic account of the Eucharist.

At this point it may be asked whether this discussion concerns a phenomenology or a theology of the Eucharist. In this thesis the priority is phenomenology, but it is methodologically necessary to explore the theology because the theologies form part of the traditioning. To attain a phenomenology of relational intimacy in traditioning the theologies of divine, Christological and ecclesiological intimacy need to be understood. Therefore, the theologies are explored because they link so strongly to the temporality of traditioning. The testimony of the intimate witness at the side of Christ, is itself a phenomenological testimony. It is dialogical rather than discursive. This witness does not make bold unsupported claims, as Peter does; "I will lay down my life for you". ${ }^{356} \mathrm{He}$ simply stays at the side of Jesus, and conveys the impact that being at the side of Jesus has on him.

Certainly, it produces extraordinary empirical scenarios. Jesus speaks clearly and calmly to him and the Mother of Jesus, while in the depths of his mortal agony. Blood and water are

\footnotetext{
354 Jn 16:15.

355 Jn 13:20

356 Jn 13:37.
} 
seen to flow from the side of Jesus when, after his death, his side is pierced by a spear. But, in neither case is the empirical element crucial. The crucial element is the alteration, the change of heart that these poetically dramatized texts provide. The fidelity of the Mother of Jesus and Beloved Disciple at the foot of the $\operatorname{cross}^{357}$ goes to the point of sharing in the sufferings of Jesus. In this open witness to the suffering of Jesus they are also formed in a radically hospitable openness to each other. This means that radically self-giving hospitality flows from the cross and animates the community's post-crucifixion traditioning, from the outset. Blood and water flowing "immediately" ( $\varepsilon \dot{v} \theta \grave{v} \varsigma)$ from the side of Jesus ${ }^{358}$, means that the Beloved Disciple has seen how the sacraments of baptism and Eucharist flow from the cross as nourishment for the tradition. These are the crucial points that this chapter explores. It seems that the Johannine community had grasped a revelation that, through shared historical suffering, relationships create relationships. The Johannine writings were written out of a desire to bring forth a relational world, modelled on the relationality of Jesus. This thesis relies on the Johannine sense that relationality was expressed in the Eucharist. Therefore, the Eucharistic elements in John's Gospel provide significant information on relational traditioning. It is this strand in the text that pre-occupies this thesis.

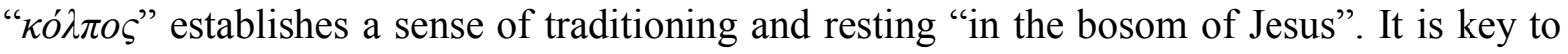
understanding the earliest stages in the advent of the post-apostolic Church. This is expressed in the structure of the Gospel. The Gospel is in two parts and there are only two uses of "кó $\lambda \pi o \varsigma " ;$ one in the opening section of the first part, the other in the opening section of the second part. A second matter is what " $\kappa o ́ \lambda \pi o \varsigma$ " contributes to the senses of revelation and traditioning. Both, the structural role of the word and the contribution it brings to the ideas of revelation and tradition are important and cannot be completely separated from each other. However, literary structure is at the service of revelation. Therefore, the emphasis will be on the power of the texts to communicate revelation, making the Father known. ${ }^{359}$

The second use of "кó $\lambda \pi o \varsigma$ ", comes in a passage which shows the Son accomplishing this precise mission. He communicates intimate revelation at the Supper. After hinting at his impending betrayal, ${ }^{360}$ Jesus reveals his own identity, by applying the Father's Name to himself; "I AM." 361 . This is not an identity established through his self-assertion. "It is the

\footnotetext{
357 Jn 19:25-27.

358 Jn 19:34.

359 John $1: 18$

360 Jn 13:18.

361 Jn 13:19.
} 
name the Father has given him." 362 Jesus then reveals the blessing of receiving the one whom Jesus sends ${ }^{363}$. Then Jesus becomes "troubled" and prophesies, "One of you will betray me $(\pi \alpha \rho \alpha \delta \omega \sigma \varepsilon l) " 364$. Moments later it emerges that "the disciple Jesus loves" has been resting "in

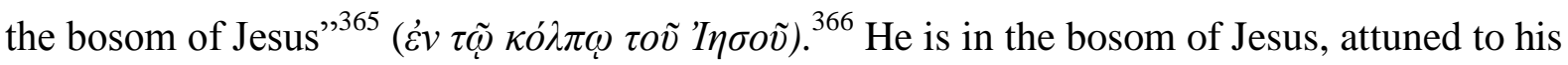
heart. Therefore, he knows the motives as well as the words and deeds of Jesus. He knows their truth at its source.

The author of the Gospel also shows the Beloved Disciple is prepared and sent from the bosom of Jesus, the way Jesus has been prepared and sent from the bosom of the Father. Therefore the metaphor of " $\kappa o ́ \lambda \pi o \varsigma$ "synthesizes two sayings in the Gospel. The first is, "as the Father has loved me, I have also loved you, remain ("dwell" " $\mu \varepsilon ́ v \omega ")$ in my love." "367 The second, Jesus speaks in prayer to the Father: "as you have sent me into the world, so I have sent them into the world." 368

When these texts are read in relation to John 13:19-20 and 23, they expose a profoundly resourced sense of mission. The one who is sent is sent from bosom, the lap or womb of the one who sends. Furthermore, having been so close to Jesus at the supper, the Beloved Disciple must go through a further process of induction. In this entire process he stays with Jesus, closer to his side than anyone else.

In the revelation of this mission, the image of a tent is very pertinent. The one who is sent does not depart from the dwelling place but brings the goodness of the dwelling place to those to whom she or he is sent. Therefore, Jesus, who dwelt creatively "in and for the heart

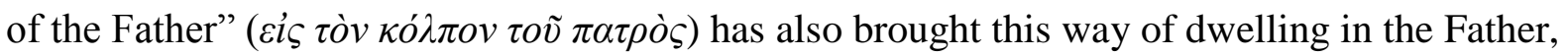
to "the disciple whom he loved". He has not only given an appreciation of the Father as a person to be trusted and sought. He has communicated the Father as a loving dwelling place to be shared. The Father is the Son's dwelling place which the Son brings into the world. The

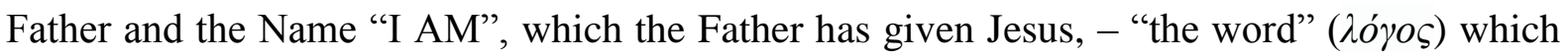
is Jesus - form a temple, a dwelling place of love which the Beloved Disciple, like Jesus before him, has been sent to bring into the world.

\footnotetext{
362 Jn 17:11.

363 Jn 13:20.

${ }^{364}$ Jn 13:22.

${ }^{365}$ Jn 13:23.

366 Jn 13:23.

367 Jn 15:9.

368 Jn 17:8.
} 
When the word is understood to be not only a proclaimed word but also a relational dwelling place it becomes evident that the Gospel cannot be shared without the grace of learning to dwell together. The mission expressed in John's Gospel, 'to make all people one with the oneness of the Father and the Son', ${ }^{369}$ was not pursued by evangelization alone. This task relies on the traditioning of love. After the example of Jesus - "the word made flesh" who "pitched his tent ( $\dot{\varepsilon} \sigma \kappa \eta ́ v \omega \sigma \varepsilon v)$ among us"370 - the mission of the Gospel is not only the communication of a word, but the handing on of a dwelling and a way of dwelling.

These pious reflections have a point that goes beyond piety and contributes to social science. They exhibit a process of traditioning. John's Gospel exhibits the post-apostolic traditioning that motivated the establishment of the scriptures and the traditions. The traditioning of the word made flesh, is reliant on his practice of "dwelling in love". Therefore, the word of Jesus, "dwell in my love",371 seems to be a priority that the Johannine community places above evangelization. In its evangelization, as in its conviviality, the life of love forms the source, process and goal of the Johannine community. "All people will know you are my disciples if you love one another." 372 But, traditioning is reliant on meaningful historical events. The depths of spirituality described in the word "“" $\delta$ ' $\lambda \pi \rho \varsigma$ " do not provide the tangible sense of history necessary for the progress of a tradition. To take the traditioning from intimacy of the Father, the Son and the Beloved Disciple in the bosom of Jesus, it is necessary to introduce a more visible kind of reference. In conjunction with " $\kappa o ́ \lambda \pi o \varsigma$ " the second of the side words, " $\sigma \tau \tilde{\eta} \theta o \varsigma "$, provides a way to articulate the way in which the Gospel breaks through from the intimacy of Jesus and the Beloved Disciple and testifies in the historical world.

\section{(ii) " $\sigma \tau \tilde{\eta} \theta o \varsigma " / “ B r e a s t /$ Chest"}

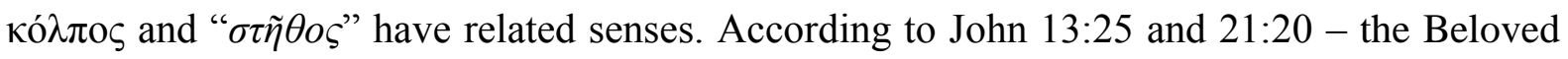
disciple rested "on the breast of Jesus" at the Supper. These uses of " $\sigma \tau \tilde{\eta} \theta o \varsigma$ " do not articulate the eternal and spiritual intimacy offered through the uses of " $\delta o ́ \lambda \pi o \varsigma$ " but they do refer to the historical occurrences of that intimacy. These occurrences are expressions of the Beloved Disciple's fidelity. The differences between the nouns is evident in the prepositions they take.

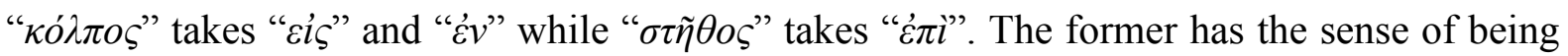

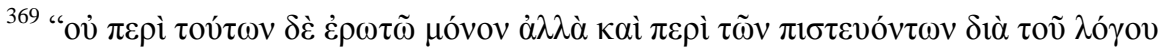

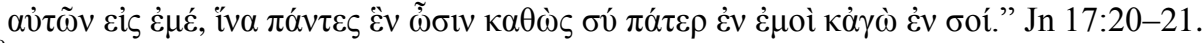

${ }^{370}$ Jn $1: 12$.

371 Jn 15:9.

372 Jn 13:35.
} 
"in" while the later has the sense of being "on". Therefore, "кó $\lambda \approx \circ \varsigma$ " refers to the embracing depths of the eternal heart of the Father ${ }^{373}$ and the embracing depths in the heart of Jesus. ${ }^{374}$ On the other hand, " $\sigma \tau \tilde{\eta} \theta o \varsigma$ " refers to the historical evidence of Beloved Disciple's intimacy with Jesus. Others are not party to the intimate depths of this bond, but they can see, through the evidence of history. They can also imitate and grow in this practice of intimation, through their own eucharistic worship. Therefore, " $\sigma \tau \tilde{\eta} \theta o \varsigma$ " refers to the Beloved Disciple's historical work of traditioning that intimacy, rendering it available for others. One of those ways is through his sustaining the celebration of the Eucharist. Through his last supper testimony, his evident intimacy has a hidden depth, “Ẻv $\tau \tilde{\omega} \kappa o ́ \lambda \pi \omega$ ”. Nevertheless, it also has an historical and institutional facticity. His longstanding witness to the celebration of the Eucharist is expressed in the concluding narrative of the Gospel. He was "resting in the supper on his

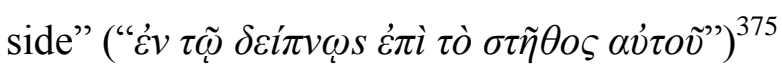

Structurally, " $\kappa o ́ \lambda \pi o \varsigma "$ and " $\sigma \tau \tilde{\eta} \theta o \varsigma "$ combine to form clues that indicate the most important turning point in the structure of the Gospel. First, concerning the overall structure of the Gospel, there is an inclusion between " $\kappa o ́ \lambda \pi o \varsigma$ " at the beginning ${ }^{376}$ and " $\sigma \tau \tilde{\eta} \theta o \varsigma$ " at the end ${ }^{377}$. Secondly, these words also form two distinct inclusions which designate the two halves of the Gospel. The first half is formed by " $\kappa o ́ \lambda \pi o \varsigma$ " in 1:18 and 13:23. The second half is formed by " $\sigma \tau \tilde{\eta} \theta o \varsigma "$ in 13:25 and 21:20. Further evidence for this structure is in the decisive moment of verses 13:19-25.

These two words draw attention to that moment at which Jesus - who has come from the Father and is now returning to the Father ${ }^{378}$ - provides for the continuation of his mission after he has gone. At this point, the mission that passes from eternity into history is conveyed to the Beloved Disciple. It is a moment of the deepest crisis, when the inner eternal breast of Jesus begins to open into the crises of history. Now Jesus makes his last supper "I AM" statement $^{379}$. He also announces that he is going to be betrayed ${ }^{380}$. And he articulates the missionary movement of John's Gospel and the Johannine community. “Amen, amen, I tell

\footnotetext{
373 Jn $1: 18$.

374 Jn 13:23.

375 Jn 21:20.

376 Jn 1:18.

377 Jn 21:20.

${ }^{378}$ Cf. Jn 13:1 and 13:3.

379 Jn 13:19.

${ }^{380}$ Jn 13:18, 21.
} 
you, who receives anyone I send receives me and who receives me receives the one who sent me". ${ }^{381}$

The "I AM" statement and the mission statement occur between the two prophesies of betrayal. They exhibit the turning point in the mission of Jesus. He has come from the heart of the Father. ${ }^{382}$ Now that he has gone as far as he can go (to the point of betrayal unto death) he is going to send another from his heart ${ }^{383}$ into the world. Hence the saying at this point, "whoever receives the one I send." 384 This has obvious significance for the ones whom Jesus is going to send from the last supper and in a special way it refers to the Beloved Disciple. He is already in the heart of Jesus.

"кó $\lambda \pi$ o " and " $\sigma \tau \tilde{\eta} \theta o \varsigma$ " describe the eternal and historical senses of Eucharistic intimacy and fidelity. The former concerns the revelatory intimacy between Jesus and the Beloved Disciple. The latter concerns the revelatory gift of the Beloved Disciple, before the Church, with Jesus. Jesus who has declared his name to be "I AM" to the disciples, conveys the meaning of "I AM" at an intimate depth to the Beloved Disciple. And as the revelation from the Father sent Jesus on mission, so this revelation to his Beloved Disciple sends his Beloved Disciple on mission. But the revelation has one depth in the heart of Jesus before the Father and another depth on the side of Jesus before the other disciples. His mission manifests, to the other disciples, a certain intimacy between Jesus and the Beloved Disciple. This

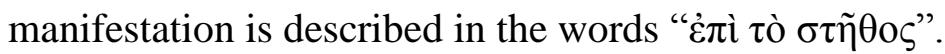

The twofold witness to intimacy with Jesus, one before the Father in eternity the other before the disciples in history, is sustained in both its horizons through the Eucharist. When the term " $\sigma \tau \tilde{\eta} \theta 0 \varsigma$ " is used at the end of the Gospel. The " $\dot{v}$ " preposition is retained from the last

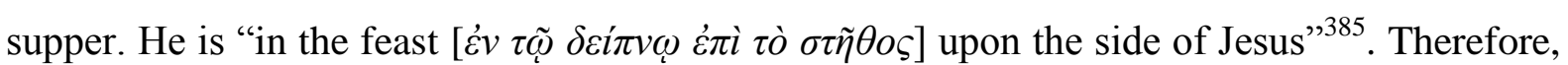
he is in the feast on the side of Jesus at the beginning of his mission and at the end. Like Jesus, who is always with the Father through his sovereign intimacy with God, so, the Beloved Disciple is always with Jesus through his eucharistic intimacy with Jesus. The Eucharist binds the Beloved Disciple to Jesus at two levels, the level of divine eternal intimacy and at the level of ecclesial historical intimacy. The level of divine intimacy, expressed in the name I AM, is also articulated throughout chapter 17. The culminating verse

\footnotetext{
381 Jn 13:19.

382 Jn $1: 18$.

383 Jn $13: 23$.

${ }^{384}$ Jn 13:20.

385 Jn 21:20.
} 
of the last supper passage makes this level of intimacy clear. "Father I have made your name known to them and will continue to make it known so that the love with which loved me may be in them and so that I may be in them." 386 The ecclesial historical intimacy also binds Jesus to the Church.

(iii) " $\pi \lambda \varepsilon v \rho \alpha{ }^{\prime 387}$ literally "rib" by extension "side"

The noun is found in John 19:34-35. The side ( $\pi \lambda \varepsilon v \rho \alpha$ ) of Jesus is pierced with a spear. "Immediately blood and water came out. ${ }^{388}$ The Beloved Disciple witnesses this occurrence. His testimony gives rise to the Evangelist's reference to the truthfulness of the Beloved Disciple's witness ${ }^{389}$.

A number of significant points relate to this noun. Firstly, it is more polysemic than the other nouns for "side". One result of the polysemy is that it unites the intimate spiritual and external historical meanings of the other two nouns. Secondly, the crucial factor about this side scripture is that it articulates the point about the Beloved Disciple. He is the witness whose witness is true. His witness is eucharistic, his witness is true and he has the witness that overcomes betrayal. This faithfulness at the side of Jesus makes him a truthful witness. This makes him the absolutely different from Judas who leaves the supper ${ }^{390}$ and is a false witness. Furthermore, the Beloved Disciple's overcoming of betrayal concerns the transformation or redemption of traditioning ( $\pi \alpha \rho \alpha \delta i \delta \omega \mu l-\pi \alpha \rho \alpha ́ \delta \sigma \sigma \iota)$ ). At the foot of the Cross, he has witnessed the faithfulness of Jesus. In this faithfulness, Jesus traditions $(\pi \alpha \rho \alpha \delta i \delta \omega \mu)$ his spirit. ${ }^{391}$ Jesus, who is handed over, hands over the spirit. This is the redemption of traditioning. This point also relates to traditioning $(\pi \alpha \rho \alpha \delta i \delta \omega \mu \imath)$ in Paul.

Traditioning provides the key to the significance of the Eucharist as it enters the postapostolic era. It flows from the traditioning of Jesus. It serves the redemption of traditioning. Jesus who has been handed over, does not retaliate. He lets himself be handed over and thereby testifies to his invincible loveableness. He reveals forgiveness in the outpouring of his Spirit, the way of redemption. But this openness to the will of the Father has already been

\footnotetext{
386 Jn 17:26.

387 “ $\pi \lambda \varepsilon v \rho \alpha ́$ pleurá, plyoo-rah'; of uncertain affinity; a rib, i.e. (by extension) side: - side,” Strong,

Concordance, G4125.

${ }^{388}$ John 19:34.

389 Jn 19:35.

390 Jn 13:30.

391 Jn 19:30
} 
revealed to the Beloved Disciple at the last supper. Not that it was completely revealed at the supper. But its prophetic path was revealed; and, as the last scenes of the Gospel show, the Beloved Disciple was on the path of that revelation, from his first encounter with Jesus until Jesus' return. ${ }^{392}$

Another note about " $\pi \lambda \varepsilon v \rho \alpha$ ". There is a strong argument that the Gospel ties the sense of "rib" in " $\pi \lambda \varepsilon v \rho \alpha$ " to the imagery of Adam and Eve. As Eve was formed from the rib of Adam as he slept, so the sacramental community is formed from the side (" $\pi \lambda \varepsilon v \rho \alpha$ " "rib") of Jesus as he sleeps in death on the Cross. This is strengthened by the argument that while she stands at the foot of the cross, Jesus calls his mother " $v^{\prime} v \alpha l$ ". ${ }^{393}$ In the Septuagint account of the creation of Eve, Adam uses the same noun " $\gamma v v \eta^{\prime}$ " to refer to Eve ${ }^{394}$. The nuptial sense of the text is intensified when the Gospel's other use of " $\gamma v$ vol" 395 is considered: it occurs at "the wedding feast of Cana". Also, the Septuagint has Eve created from the " $\pi \lambda \varepsilon v \rho \alpha ́$ " of Adam ${ }^{396}$. This imagery inevitably generates the sense of the Eucharist as the marriage feast which sustains the Church coming from the side of Christ. ${ }^{397}$

Mary is called "Woman" (" $\gamma v$ vol") at the wedding feast of Cana and again at the foot of the cross. Both scenes are redolent with the symbolism of the sacramental meal, marriage and the genesis of the Church. Therefore generative and nuptial imagery pervades the symbolism of the Cross. The symbolism of water (Baptism) and blood (Eucharist) flowing from the side of Jesus, giving birth and nourishment to the New Church as he hung upon the Cross, has become, almost certainly, the most exalted and powerful depiction of the Eucharist in the history of the Church. This symbolism expresses both the identity and relationality of the Eucharist. The identity of the Eucharist is that it is the sign of the union of Christ and his Church. The relational dynamics that produced this meaning have still to be explored in this thesis.

(d) Traditioning and the Transformation of Betrayal

Before examining the implications of the Beloved Disciple's witness at the side of Jesus, and the witness of Jesus at the side of the Father, some observations need to be made about the as

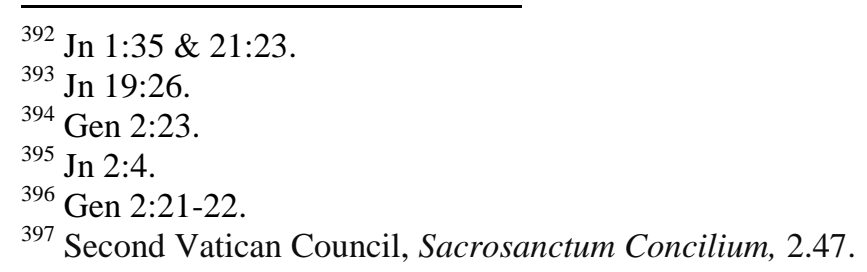


yet undeveloped theory of traditioning. In the New Testament traditioning (" $\pi \alpha \rho \alpha \delta$ í $\delta \omega \mu \mathrm{\imath}$ ") carries a dreadful trace, the spectre of betrayal. Responses to that horror cannot help but pervade all the Eucharistic texts of the New Testament. The effort to write this thesis began with those problems in mind. However, the other side to this crisis, is the profound practices of traditioning that addressed that problem. This thesis reads John's Gospel in particular, as a response to the destructive practice of self-centred traditioning by articulating a sense of relational traditioning.

A further issue emerges through these passages: the transformation of traditioning, from betrayal to revelation. This teaching is also found in Paul but this part of the thesis focuses on its occurrence in John. In John, the teaching of traditioning is not based in identity but intimate relationality. At the supper, the Beloved Disciple intimately witnesses the revelation of who Jesus is, he is able to remain with Jesus in his rabbinic path of being traditioned and traditioning. The other disciples lack the revelation necessary to survive the scandal of the cross unscathed. But the Beloved Disciple has the revelation of the full depth of handing over (" $\pi \alpha \rho \alpha \delta i \delta \omega \mu \imath ")$. He knows that Jesus being handed over is necessary to the revelation of his name, I AM. He has been privy to these revelations while he was resting " $\dot{\varepsilon} v \tau \tilde{\varphi}$ $\kappa o ́ \lambda \pi \omega \tau \sigma \tilde{v}$

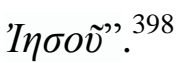

The theory advanced here is that, from the point of the last supper revelations the Beloved Disciple carries the intimate gift of redemptive and healing traditioning. He is one with Jesus in sustaining the mission which redeems traditioning from betrayal.

The roots of this theory need some exposition. There are various ways it may be progressed. There is the much-needed reflection on the texts to discover to what degree the extreme ambiguities of $\pi \alpha \rho \alpha \delta i \delta \omega \mu l-\pi \alpha \rho \alpha ́ \delta o \sigma l \varsigma$ formed an explicitly recognised problem for the New Testament authors. New Testament authors, were certainly sensitive to the crisis of traditioning, the crisis of faithfulness. This is clearly expressed in Matthew 26:22. After Jesus predicts that "one of you will betray $(\pi \alpha \rho \alpha \delta i \delta \omega \mu l)$ me"399 "they are all very sorrowful and begin asking "is it I"”. ${ }^{400}$ Also in Mark 7:8, Jesus chastises the scribes and Pharisees for preferring "the traditions of your elders to the commandments of God." Therefore, it may usually be presumed that when they referred to traditions and traditioning, the New Testament authors were sensitive to the crisis of traditioning. Paul's uses of the noun

\footnotetext{
398 Jn 13:23.

${ }^{399}$ Mt 26:21.

${ }^{400}$ Mt 26:22.
} 
" $\pi \alpha \rho \alpha \dot{\alpha} \delta \sigma \iota \varsigma$ " and the verb " $\pi \alpha \rho \alpha \delta i \delta \omega \mu \imath$ " in 1 Corinthians 11:2 exhibit reflective use. When he wrote, "I praise you, brothers and sisters, that you remember me in all things and keep the traditions that I traditioned to you," he was consciously applying the word-group. Similarly, it would have been reflective use when he changed his use of the word group in 1 Corinthians 11:23 and only used the verb with a pronoun, - "I received from the Lord what (ős) I traditioned to you". In fact, Paul was unusual in giving any positive use to the noun at all. The Septuagint used the verb one hundred and seventy four times, but the noun only four times $^{401}$. On those four occasions, the noun formed part of a verbal construct, as in Jeremiah

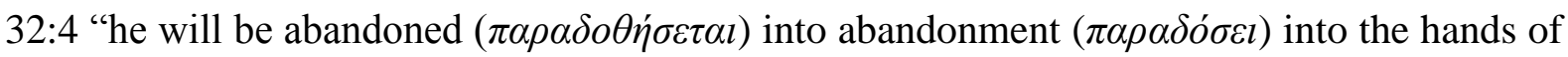

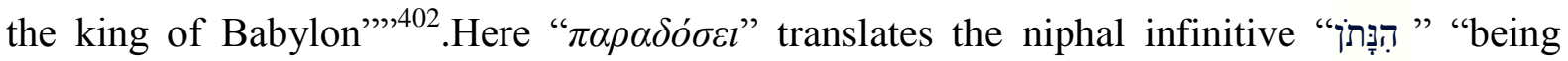
abandoned". Therefore it does not function as a noun in its own right. In fact, " $\pi \alpha \rho \alpha \dot{\delta} \delta \sigma \iota \varsigma "$ never functions as a noun in the entire Septuagint. That the noun figures, with censorship and caution in the New Testament is enough to show that the topic was not neglected in the Scriptures, and that the New Testament authors were sensitive to the crisis of traditioning, the responsibility for faithfulness throughout the generations. This thesis seeks to imitate the biblical concerns with "traditioning" and "tradition" and it undertakes its reflections with a particular emphasis. It reflects on the intersubjective relationships that are involved in traditioning. Intersubjective issues are documented in John's Gospel. With these thoughts in mind this study examines the legacy of "the disciple whom Jesus loved". It also examines the contribution of the third Author of the Gospel. The reflections in this part of chapter two are concerned with traditioning; as both an explicit and implicit concern for the biblical authors and tradents of the early Church.

John's Gospel is explored through the side scriptures because, reflections on traditions and tradition are easily exported into objective descriptions. However, the sense of traditioning in the biblical last supper and passion narratives, and especially through the side scriptures of John's Gospel - is radically bound to the subjective elements of tradition. In John's Gospel, from the moment Jesus begins his revelatory declarations concerning (i) his betrayal, (ii) the Name I AM, (iii) his mission and missioning, the Beloved Disciple is in the bosom of Jesus. Therefore, he has the revelation necessary for life-giving traditioning. He witnesses and follows in the way of the traditioning of Jesus. This does not mean this path always has the name "traditioning". Ultimately the path of intimate discipleship defies nominalisation or

\footnotetext{
${ }^{401}$ Charles Van Der Pool, The Lexical Concordance of the Apostoloic Bible, 257.

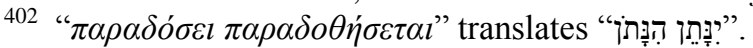


predictability. But it does involve the temporal structure of relationships and the differences between the relator and the related to. "Traditioning" refers the temporal expression of these differences.

Therefore a reflective process which may be called "traditioning" can be indicated. In John's Gospel, at the beginning of his passion Jesus is traditioned ( $\pi \alpha \rho \alpha \delta i \delta \omega \mu \mathrm{l})$. At the end Jesus traditions $(\pi \alpha \rho \alpha \delta i \delta \omega \mu \imath)$ the Spirit. There is every reason for calling this "traditioning", of the highest order. This does not imply that traditioning is completely comprehended by that reference. Nevertheless, it provides a rich field of reflection. The remaining paragraphs in Part A of this chapter seek to follow the Beloved Disciple's witness to the processes of traditioning, from the supper to the Cross.

(i) The Eucharist and the Difference between Good and Evil

The eucharist figures in the four side scriptures that concern the Beloved Disciple (John 13:23, 25, 19:34 and 21:20). The occurrence in John 19:34 is bound to John 19:35. There, as in John 21:24, the witness of the Beloved Disciple is referred to as "true"403. His truthfulness coincides with his intimacy with Jesus, his bearing witness at Jesus' side and in his bosom.

Therefore his faithfulness at the side of Jesus makes him a truthful witness and this relational truthfulness exposes the anti-relational falsehood of Judas. Judas does not stay at the side of Jesus and does not stay at the supper. He receives bread and responds to it with malice. $\mathrm{He}$ leaves the supper ${ }^{404}$ and is a false witness. The same may be said about Satan, who influences Judas. ${ }^{405}$ Satan does not witness to any relationship. In John's Gospel Jesus says of the Devil, "there is no truth in him. He speaks lies when he speaks because he speaks from what is his own" ( $\dot{\varepsilon} \kappa \tau \tilde{\omega} v i \delta i \omega v) .{ }^{406}$ He speaks without concern for relationships. He speaks without listening to another. He may be full of his own ontological agency. He is his own origin because he is a liar and the father of it (" $\alpha v^{\prime} \tau o \tilde{v}$ "). But he lacks relational passivity. Therefore, he also lacks relational agency.

\footnotetext{
403 Jn 19:35.

${ }^{404}$ Jn 13:30.

405 Jn 13:27.

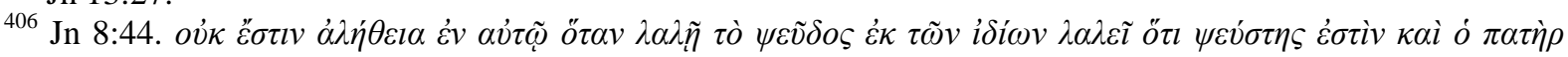

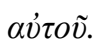


De La Potterie translates " $\dot{\varepsilon} \kappa \tau \tilde{\omega} v i \delta i \omega v$ " with "de son fond" ${ }^{407}$. Similarly, the New King James translates it "from his own resources". In clarifying this expression De La Potterie contrasts Jesus words about himself and the Holy Spirit with his words about the Devil. Idiomatically, Jesus says one thing about himself and the exact opposite about the Devil. Of

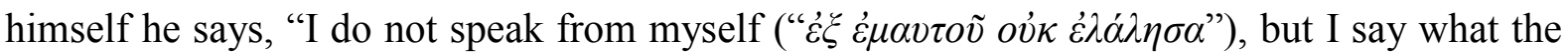
father who sent me has given me to say." 408 Of the Devil on the other hand, Jesus says, "he speaks from himself because he is a liar and he is the father of it ( $\alpha \dot{\tau} \tau o \tilde{v}){ }^{\prime 409}$. Jesus declares that he speaks from a paternal relationship. While the Devil opposes relationship. He does not accept a paternal relationship rather he originates himself with a lie rather, he does not accept the pre-originarity of relationship.

The same relational contrast emerges where the Holy Spirit is concerned. In this case De La Potterie turns to John 16: 13-14. "He will not speak from himself ( $\dot{\alpha} \varphi$ ' $\dot{\varepsilon} \alpha v \tau o \tilde{v})$ but what he

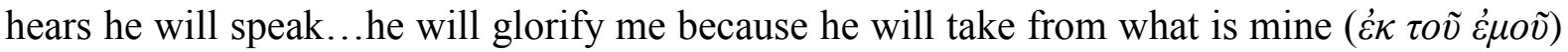
and announce it to you". De La Potterie explains that "the Spirit and Jesus transmit words that are not theirs" ${ }^{\prime 10}$. This is what this thesis means by relational traditioning. The Holy Spirit sustains it, the spirit of evil opposes it. But does it have an historical expression that goes outside its expression in the persons of the Trinity?

(ii) Relationality and Traditioning

Through his unperturbed allegiance to Jesus in the midst of betrayal, the Beloved Disciple testifies to the transformation or redemption of traditioning ( $\pi \alpha \rho \alpha \delta i \delta \omega \mu l-\pi \alpha \rho \alpha \dot{\delta} \delta \sigma l \varsigma)$.

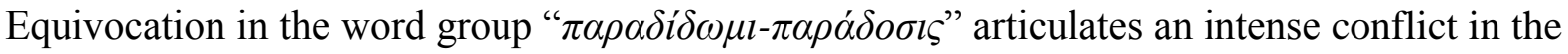
New Testament texts. The tradition that traditions from its own origin and for itself is murderous. The tradition that traditions from another and for another is life-giving. But at the heart of both these alternatives lies the word "self". The Spirit of God "will not speak from

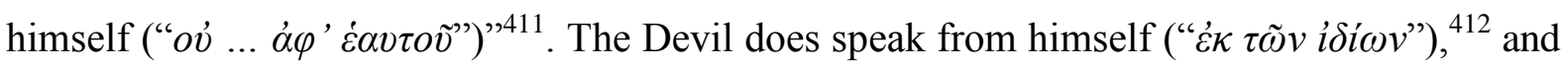
only from himself. He is the father of his own speech, without concern for relationship. This raises the question, "how does traditioning involve the self?"

\footnotetext{
407 de la Potterie, 932.

408 Jn 12:49.

409 Jn 8:44.

410 "L'Esprit et Jésu transmettent les paroles qui ne sont pas les leurs" - de la Potterie, 933.

411 Jn 16:13.

412 Jn 8:44.
} 
This discussion has involved considerations of the Eucharist, the last supper and the difference between the practices of the Beloved Disciple and Judas at that supper. But it has moved on to discussions about the Holy Spirit and the evil spirit. What does either Spirit have to do with the New Testament Eucharist? There is no mention in the Synoptics or Paul. Nor is there any mention of the Holy Spirit but only the Devil, in the meal part of John's last supper narrative. However, the Eucharist and the Holy Spirit have this in common, "traditioning". The Devil also has a limited part in this, he is at the heart of the betrayal. The last supper is offered the night before Jesus is traditioned and once his being traditioned is accomplished, the self that lives for itself has lost its power. Jesus accepts his being "traditioned" (betrayed) and ultimately he "traditioned ${ }^{413}$ the Spirit". Therefore, both the Eucharistic Jesus and the Holy Spirit express a radical relational openness and they both allow themselves to be "traditioned". Also, their traditioning is not self-traditioning. It is passive relational traditioning. They are traditioned. This traditioning is possible because Jesus, who is celebrated in the Eucharist, and the Holy Spirit are not "for themselves" but they are relational in their own selves. Jesus and the Holy Spirit could be described as "relationallytraditioned-selves". In more familiar language they could be called "relationally handed-over selves. 2 Corinthians 4:11 seems to apply the same understanding to Paul and Timothy "For we who live are always delivered $(\pi \alpha \rho \alpha \delta i \delta o ́ \mu \varepsilon \theta \alpha)$ to death for Jesus sake...so that death is at work in us and life in you". ${ }^{414}$

(iii) Hospitality, Spirituality and Agency

Because the Beloved Disciple is at the side of Jesus his self is also different to the other disciples. In John 16:32 Jesus prophecies. "The hour is coming for you to be scattered each to their own (lidos) and leave me alone. Except I am not alone because my Father is with me." But the Beloved Disciple is with Jesus. Therefore, the Father is also with him. When Jesus says to the Beloved Disciple, "son behold your mother." The Beloved Disciple takes her to

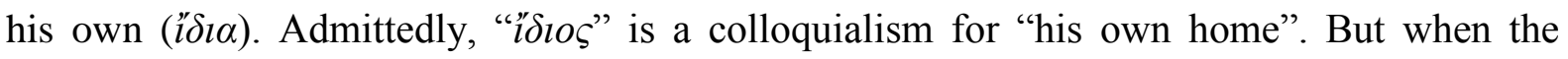
verse is compared with the text about the disciples each scattered to his or her own (" $\varepsilon i \varsigma \tau \grave{\alpha}$ " $\delta l \alpha ")$ it is clear that the Beloved Disciple is in the relationality of the one who has been handed over $(\pi \alpha \rho \alpha \delta i \delta \omega \mu \imath)$.

\footnotetext{
${ }^{413}$ Jn 19:30.

${ }^{414} 2$ Cor 4:11-12.
} 
Taking the mother of Jesus to his home is an expression of relational agency. It is an expression of agency that arises out of relational passivity. This is a strong paradigm in John's Gospel. Jesus says of himself, "this is why the father loves me, because I lay my life down in order to take it up again. This commandment I have received from my father" ${ }^{\text {"415. }}$.

The hospitality of the Beloved Disciple is exceptional. He is the only disciple to exercise hospitality at the foot of the cross. But this is because he has followed Jesus through the relational-passivity of being traditioned into the relational-agency of traditioning. Traditioning is an historical dynamic. At one and the same time it concerns both the relational passivity of the related to and the relational agency of the relator. It can only be both passivity and agency. But, in terms of meaning, relational-passivity is prior to relational agency. Relationality cannot be caused by the self. It is intrinsic to relationship that it is given by another. Therefore, passivity has a certain priority in the establishment of relational agency. This is evident in the words of Jesus to his Mother and the Beloved Disciple. Because they have accepted the passivity of suffering for one another, they begin a tradition of hospitality, relational agency. This is the way of "the disciple whom Jesus loved, who lay on the side of Jesus at the supper." ${ }^{416}$

The advent of hospitality as relational-agency, impossible without the relational-passivity that suffers for the other, unveils the crisis of identity and relationship that absorbs this study. Because the agent-relator and the patient-related to occur at the same time, it is possible for the agent to exploit the situation of being related to. But by allowing himself to be traditioned Jesus does not renounce the relational passivity of the related to. He relates as one who is surrendered to the Father and suffering for the other. However, this poses a crisis as this thesis approaches the emergence of ontological era of the Eucharist. There is a difference between an ontology which is based in relationship and an ontology which is not. The ontological era of the Eucharist is infused with relational passivity. The witness of Cyprian the martyr is the witness of one willing to suffer for his relationship with God and his neighbour. As the study below will show ${ }^{417}$, he was a man of action. But his sense of action was also based in a strongly miraculous sense of the Eucharist. He was reflecting on how to sustain the wonder of the Eucharist. Cyprian's action was at root a testimony to his relational surrender to God and Jesus in the Eucharist. On the other hand, his intellectual emphasis on

\footnotetext{
415 Jn 10:17.

416 Jn 21:20.

${ }^{417} \mathrm{Cf}, 128-133$.
} 
the identity of the Eucharist and his intellectual neglect of the relationality of the Eucharist meant that the interpretations of the Eucharist would develop an imbalance, an emphasis on identity and a neglect of relationality. These matters are approaching, however the next section reflects on the issues of passivity and agency as these emerge at the end of John's Gospel.

\section{Peter and John: Some Basic Traditional Paradigms}

At the end of the Gospel Jesus rebukes Peter for asking him a question about the destiny of

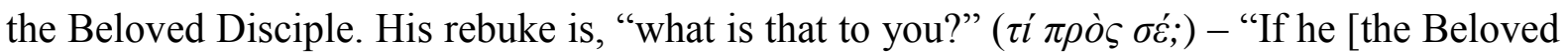
Disciple] should dwell until I return: what is that to you? You follow me". ${ }^{418}$ These are the last words of Jesus in the Gospel. "What is that to you?" The Beloved Disciple can "dwell" but Peter must "follow". His centre of gravity differs from that of his brother and "the other disciple". The text demonstrates that his centre of gravity was eternally changed on the morning he first met Jesus. "You will be called Kephas"419.

Peter's path is troubled, there is a lot to be learned from it. In John's Gospel, his problems seem to begin at the last supper. There, unsolicited, he asserts "I will lay down my life for you." 420 Jesus answers with another rhetorical question: "Will you lay down your life for me? Amen amen I tell you, before the cock crows you will have denied me three times."

These observations exhibit a strong element of pain in the history of Peter. They are not the final word but they prepare the way for the Evangelist's teaching about what would soon be called "the apostolic tradition" (Irenaeus ${ }^{422}$ ). In light of the troubling relationship of question and response - a relationship that becomes more troubling the closer it gets to the eucharist it is necessary to make a deeper exploration of the concluding scene of John's Gospel. Paradoxically, this will demonstrate that Peter's centre of gravity is in the Eucharist, but in a way that differs from that of the Beloved Disciple.

The differences between Peter and the Beloved Disciple thrive throughout the tradition. Without referring to the Eucharistic element of the text, Augustine saw in Peter both, the one

\footnotetext{
418 Jn 21:22.

419 Jn 1:40.

${ }^{420}$ Jn $13: 37$.

${ }^{421}$ Jn 13:38.

${ }^{422}$ Irenaeus, Against Heresies 3.3.
} 
who loves Christ the most ${ }^{423}$ and the church active. In the Beloved Disciple, he saw the one whom Christ loves the most and the church contemplative. ${ }^{424}$ Augustine sustained the distinction between the disciple who is most loving and the disciple who is most loved (and therefore most blessed), by treating the former as the model of the church fulfilling its earthly responsibilities, and the latter as the church anticipating its heavenly blessings.

The same distinction is reflected in the second and second to last paragraphs of the Confessions: the former speaks of humanity's ascending desire to rest in $\mathrm{God}^{425}$; the latter speaks of God's heavenly desire to rest in the soul. ${ }^{426}$ This architecture of the confessions which works out between agency towards God and passivity before or in God, exemplifies the distinction between the self as relator and the related to. Augustine's distinction is indispensable.

Another point needs to be added to bring out the value of Augustine's observation. Peter suffers a "wound of love". ${ }^{427}$ Peter, who denied Jesus three times, is asked three times by Jesus, “'do you love me?' The third time, Peter is hurt, and replies, 'You know all things, you know I love you'." ${ }^{228}$ Peter, who has promised Jesus at the last supper that he will lay down his life in love and failed him has now been lead through that wound. He is now able to follow him and to lay his life down.

The distinction between John and Peter therefore shows the difference between dwelling and following, passivity and agency. Peter's personality is geared towards agency; therefore, he is lead in the way of agency. But initially his agency is unwise. At the last supper, he insists unsolicited that he will lay down his life for Jesus. Not only that, but Jesus prophesies that he will fail. ${ }^{429}$ Now Jesus reveals to him that the hurt in that failure has become part of his journey of love. In the passivity (or suffering) of that hurt, he will continue his active way of following Jesus - even to the point that he will die for him.

\footnotetext{
423 Jn 21:15.

${ }^{424}$ Augustine, Tractates on the Gospel of John, 124.4.

425 "You have made us for yourself and our hearts find no peace until they rest in you." Augustine, Confessions, Translated by R.S. Pine-Coffin, Harmondsworth: Penguin Books, 1984, 21

426 "In that eternal sabbath you will rest in us", Confessions, Pine-Coffin, 346.

${ }^{427}$ Baron Friedrich Von Hügel, The Mystical Element of Religion, 187. The expression "wound of love" sheds immense light on Von Hügel's treatment of passivity in the life of Catherine of Genoa.

428 Jn 21:17.

429 Jn 13:37-38.
} 
In these verses, and in the discussion by Augustine, a perennial distinction comes forth: the distinction between high and low traditioning. This distinction will be clarified in Part B of this chapter.

(a) The Beloved Disciple Finds His Dwelling Place

Comparing Peter and John we find the dynamics of rest and restlessness, dwelling and following, that moved the apostolic and now the post-apostolic Church. These same dynamics are reflected in the Eucharist which is at once a Passover meal and a Sabbath meal. In accord with the Synoptic and Petrine traditioning of the meal. It has the sense of being eaten in haste, as food for the journey. In accord with the Johannine traditioning of the meal it is also celebrated at rest, a banquet in a stable dwelling. Through the Eucharist the Beloved Disciple dwells from beginning to end and, in the end, is greeted by the gift of eternal life. ${ }^{430}$

Therefore, at the end of the Gospel, the attestation is overwhelming, the Beloved Disciple has learned how to dwell. This is his internal authority, and he is protected from the lesser concerns of external authority. "If he is to dwell until I return, what is that to you?!"431 Apart from the question at the beginning of the Gospel, no questions are asked of the Beloved Disciple. He knows how to answer. He "does the truth"432. First, Jesus asks, "what do you seek?" the Beloved Disciple, answering a question with a question, expresses his desire perfectly. "Where do you dwell?" ... "Come and see," replied Jesus. "And the two disciples went with him and they dwelt with him that day". 433

The question is transformative, Jesus asks "what do you seek?" - the Beloved Disciple's response, with his companion Andrew, sidesteps the impersonal pronoun and discreetly asks for a personal relationship with the rabbi. "Where do you dwell?" - "Come and see?" It is a magnificent testimony to the I-Thou character of their love that this opening statement, and question, is the only time Jesus uses the impersonal pronoun in the highly significant $\zeta \eta \tau \varepsilon \tilde{I} \varsigma$ $(\text { seek })^{434}$ questions of the Gospel. This shows that this is not a plain question about dwelling. This is the disciple's request for intimacy. A respectful request, which includes the companionship of the disciples. He seeks the rabbi in his dwelling, but with Andrew, rather

\footnotetext{
${ }^{430}$ de la Potterie, La vérité dans saint Jean, 2:562-565.

${ }^{431}$ Jn 21:23.

${ }^{432}$ Jn 3:21.

${ }^{433}$ Jn 1:38-39.

${ }^{434}$ Jn 1:38.
} 
than seeking to claim the rabbi for himself. So the Beloved Disciple opens the heart of the rabbi not only for himself, but so that the rabbi may give his blessing and his teaching, and reveal his excelling goodness to others. He treasures the rabbi's openness towards him and towards the other. Through his esteem for Jesus' revealing heart, the Beloved Disciple has no problems questioning Jesus. At the last supper Peter asks him to ask Jesus about "the betrayer". Nothing is too sensitive for the Beloved Disciple's intimate gift of enquiry. He has found his dwelling place in the house of revelation, the heart of the rabbi. At the end of the Gospel, the Beloved Disciple has no questions. The question has been forgotten, he now dwells in the language of the rabbi's response. "Come and see".

(b) Peter and the Eucharist of the Relational Agent

The conclusion of John's Gospel provides a comparison of the eucharistic callings of Peter (who "follows") and John (who "dwells"). A comprehensive model for the post-apostolic Church.

Reflecting on Augustine's distinction between the active life of Peter and the contemplative life of John, it is necessary to see that there is a passivity that unites the way of John and the way of Peter. They both have a subjective share in the suffering of the cross. The Beloved Disciple exhibits overwhelming tranquillity as he stays at the side of Jesus, but his dwelling is at the suffering side of Jesus. Therefore, more than anyone he is one with the suffering of the Cross. However, Peter also enters into the subjective depths of that suffering through his life of repentance. This is demonstrated when he responds to Jesus' questions, and he is hurt when Jesus asks him a third time, "do you love me?" Jesus tells Peter not to concern himself with the Beloved Disciple, but to continue in the act of following Jesus. But through his passivity to the suffering of the cross, his agency has been converted from a fallible and individual agency into a faithful and relational agency.

It is not necessary to see the distinction between Peter and the Beloved Disciple as a distinction between two individuals. It is possible to see them as two testimonies about different expressions of the disciple's life. This unity between the contemplative and the active life was well expressed by Teresa of Avila in passage describing the fulfilment of the mystical life "Martha and Mary hold hands." 435

435 Teresa of Avila, The Interior Castle or the Mansions, 293. 


\section{Part B: Looking Forward from the Biblical Era: The Next Two Centuries}

This historical analysis begins by examining Cyprian's treatment of the eucharist as an historically identified $\operatorname{sign}^{436}$ and his reference to its sacramental practice as "the tradition of the Lord" ${ }^{437}$ (traditio dominicae). ${ }^{438}$ Having exhibited the identity of the sign, as achieved by Cyprian of Carthage, $253 \mathrm{CE}$, the study shows that for the earlier Clement of Alexandria, ${ }^{439}$ $190 \mathrm{CE}$, the eucharist defied historical identification and Clement's arcane "tradition of the

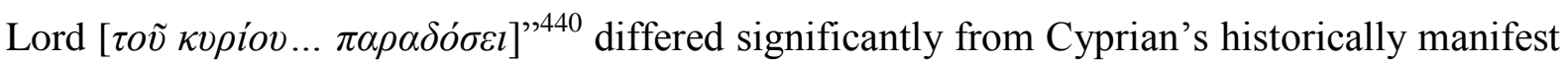
"tradition of the Lord". Clement's distinction, between "the tradition of the Lord" 441 and "the canon of the Church" ${ }^{\text {442 }}$ sustained an already established New Testament distinction between high (apocalyptic) and low (historical) traditioning. This distinction becomes clearer when Clement's and Paul's uses of the word group " $\pi \alpha \rho \alpha ́ \delta o \sigma l \varsigma-\pi \alpha \rho \alpha \delta l \delta o ́ v \alpha l$ "443 are compared.

The distinction between high and low traditions is not articulated in Cyprian's determination of the eucharistic tradition. However, at the basis of the difference between Clement and Cyprian lies their sense of connexion with the relationality of the infinite. Clement stresses an arcane and affectionate relationship between Christ and the Gnostic disciple ${ }^{444}$. Cyprian stresses an historically manifest and pragmatic relationship between Christ and the disciple. Therefore, like Clement, Cyprian also sustains the sense of infinite relationship, but he brings with it an emphasis on the identity of the manifest traditional sign. This emphasis, does not make Cyprian's attitude to the Eucharist mundane, far from it. He has an exceptional wonder at the sanctifying power and extraordinary uniqueness of the Eucharist, but he remains focused on it as an historically manifest sign. For Cyprian, a lack of pragmatic emphasis leads to a dilution of the faith. But for Clement, this emphasis would be a distraction from the

\footnotetext{
${ }^{436}$ Cyprian, "Epistle LXII" (English) and "Epistula LXIII" (Latin). Note different numbering in the English (ANF) and Latin (CSCO) editions of Cyprian's writings due to Ad Donatum being included as Epistle I in the latter.

437 "Epistle LXII", 2.

438 "Epistula LXIII", 2.

${ }^{439}$ Clement, The Stromata. Translated by William Wilson. From Ante-Nicene Fathers. Vol. 2. Edited by Alexander Roberts, James Donaldson, and A. Cleveland Coxe. Buffalo, NY: Christian Literature Publishing Co., 1885. Revised and edited for New Advent by Kevin Knight. http://www.newadvent.org/fathers/0210.htm. Cf also, Clement, The Paedogogus, also from Ante-Nicene Fathers. Vol. 2... Revised and edited for New Advent by Kevin Knight, http://www.newadvent.org/fathers/0209.htm.

${ }^{440}$ Clement of AlexandriaStromata, 7.16.104.2.

${ }^{441}$ Stromata, 7.16.104.2.

${ }^{442}$ Stromata, 1.19.96.1.

4431 Cor 11:23.

${ }^{444}$ Gnostic is capitalised to portray Clement's distinction between Christian Gnostics and nonChristian gnostics.
} 
spirituality of the faith. The dichotomy between active and contemplative spiritualities is well known. It pervades the later traditions.

\section{Cyprian's Eucharist}

In 253, in Cyprian's Epistle to Caecillius of Bilthra, ${ }^{445}$ the Eucharist received its first fully explicit and enduring definition. The purpose of the letter was to correct the unorthodox practice of using water instead of wine in the eucharistic cup. In response Cyprian describes both the orthodox practice and the reasons for adhering to it. The practice is to use wine not water in the Eucharistic cup. The reason for keeping this practice is that it is "the tradition of the Lord". ${ }^{446}$ It is the "imitation" 447 of the Lord. Referring to the biblical last supper he wrote, "in offering the cup, the tradition of the Lord must be observed" 448 - "How shall we drink the new wine of the fruit of the vine with Christ in the kingdom of his father, if in the sacrifice of God the Father and of Christ we do not offer wine, nor mix the cup of the Lord by the tradition of the Lord?" 449 He also gave an account of why this imitation is a sacrificial imitation. It is a sacrifice because it is "the sacrament of the Passion of the Lord." ${ }^{450}$ This seems to have been the first prescriptive definition of the Eucharist as a pragmatic imitation of the biblical last supper. Not only that, it was also the first reference to the sacramental practice as "the tradition of the Lord". He therefore established the identity of the eucharist as a last supper mimesis in the tradition of the Lord. He also identified that tradition as an historically recognizable tradition, requiring the use of wine at the liturgical celebrations.

His was a very significant statement in establishing both the traditional roots and the horizons of the sacrament. It gathered the most formative views and defined the parameters of the celebrations and discussions for the next 1800 years. The above reference to Zwingli ${ }^{451}$, shows that, even outside the sacramental traditions the eucharist is understood to be a last supper mimesis.

\footnotetext{
445 "Epistle LXII"

446 "Epistle LXII,". 2

447 "Epistle LXII", 14.

${ }^{448}$ Cyprian, "Epistle LXII," 2.

${ }^{449}$ Cyprian, "Epistle LXII," 9.

${ }^{450}$ Cyprian, "Epistle LXII," 14.

${ }^{451}$ See Introduction, (e), p. 6 above. Zwingli, Action oder Bruch des Nachtmahls, "The way Christ instituted the Supper: ... 'On the night in which He was betrayed and given up to death, Jesus took bread: and when he had given thanks, he brake it, and said, take, eat; this is my body: do this in remembrance of me. After the same manner also, he took the cup after supper, said thanks, and gave it to them, saying, Drink ye all of this..."
} 
Tradition is the reason this imitation should be sustained. Cyprian states the reason for this twice in the first paragraph ${ }^{452}$, once in the very short concluding paragraph ${ }^{453}$ and also at the beginning of his theological argument, "the tradition of the Lord must be served" 454 . Cyprian could not have been more emphatic.

He has also given the new expression further developments. "Tradition of the Lord" had been used previously by Clement of Alexandria. ${ }^{455}$ But Cyprian gave it a new meaning. He argued that the eucharist is necessarily an imitative celebration of the last supper because that is the historically established "tradition of the Lord". This explicit identification of the last supper and "the tradition of the Lord" was new. In a verbal expression, Paul taught that he had traditionally "received" the sacrament of the passion "from the Lord." expression, Cyprian taught that the sacrament of the passion is "the tradition of the Lord". Therefore, what had been referred to in the third decade of the Eucharist through the verb "to tradition," was now referred to in the third century through the noun "tradition".

This difference raises an epistemological issue. To what extent could the verbally and nominally sustained signs be considered the same sign? The answer to that question depends on the dimensions through which the Eucharist is envisaged. If the eucharist is defined as a last supper mimesis, then both Paul's and Cyprian's treatments refer to the same sign. That is the way the eucharist is treated in this thesis. The justification for treating it as a sign of last supper mimesis, is not only because the tradition defines it that way, but also because, pragmatically, this is the sign through which the eucharistic tradition forms itself. It is the sign of Eucharistic traditioning.

But the effects of Cyprian's statement require analysis: it rendered explicit, the relationship between the sense of sacrifice and the sense of tradition and established that the eucharist has an explicit traditionally determined identity. In Cyprian, tradition and sacrifice seem to be very closely related. The element of sacrifice is also given immense designations: "the sacrament of the passion of the Lord" 457 and "the sacrifice of God" 458 . The tradition of the Lord, since it defines the sacrifice of the Lord, has the greatest theological significance.

\footnotetext{
452 “Epistle LXII," 1.

453 "Epistle LXII," 19.

454 ,"Epistle LXII," 2.

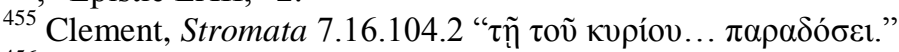

${ }^{456} 1$ Cor 11:23.

457 "Epistle LXII," para. 14.

458 "Epistle LXII," para. 9.
} 
To appreciate the relationship between sacrifice and tradition it is important to understand the contribution that imitation brings to the tradition. "That priest truly functions in the place of Christ who imitates what Christ did." 459 This imitation clarifies the role of the priest. The priest is a tradent, who hands on the tradition through imitation. The imitation unites the sacrifice and the tradition. Therefore, the eucharistic sacrifice, or sacramental "sacrifice of the Lord" is described as an imitative sacrifice. The sense of imitation extends to the supper as a whole. Not only the priest, but all who participate are involved in the imitation of Jesus. Therefore, "the cup which is offered in remembrance of Him should be offered mingled with wine." 460

Three cardinal reasons are given for this sacrificial motif, the first has already been described, it is an imitation of the passion. ${ }^{461}$ Secondly, it is "the tradition of the Lord". The reference is particularly strong in paragraphs $1^{462}$ and $2^{463}$. Thirdly, it is "the truth". The opening paragraph and concluding paragraphs show the importance of "truth" for Cyprian. The opening paragraph associates "tradition" with "the truth of the Gospel." It asserts that the letter is written that "one [who is in error by deviating from the tradition] may be returned by the perceived light of the truth" ${ }^{\text {}} 64$. The concluding paragraph strengthens this association of truth and tradition and articulates the guiding motive for his letter and the practice of the Church. The motive is "to keep the truth of the tradition of the Lord". ${ }^{465} \mathrm{He}$ advises Caecillius, "frater carissime" that this "befits our religion... and our office of priesthood"466. In "mixing and offering the chalice of the Lord" it is "the truth of the tradition of the Lord" ${ }^{467}$. This motif is also imitative and applies to the specifically sacrificial motif. It is the sense of truth that renders the traditioning possible. The sacrifice reveals the truthfulness of the Lord. The value of the sacrifice is in its faithfulness and truth. The reason the sacrificial imitation must be sustained is because it is the tradition of the Lord. But there is a question of balance or priority between them. The point needs to be clarified but it seems that the

\footnotetext{
459 "Epistula LXIII," 14: "ille sacerdos vice Christi vere fungitur qui id quod Chrisus fecit imitator et sacrificium verum et plenum offert in ecclesia Deo patri"

${ }^{460}$ Cyprian, "Epistle LXII," para. 2.

${ }^{461}$ Cyprian, "Epistle LXII," paras. 9, 14.

462 Cyprian, "Epistula LXIII," para. 1: "veritatis luce perspecta radicem adque originem traditionis dominicae revertatur".

${ }^{463}$ Cyprian, "Epistula LXIII," para. 2: "Admonitos...ut...Dominica traditio servetur neque aliud fiat a nobis quam quod pro nobis dominus prior fecit".

${ }^{464}$ Cyprian, "Epistula LXIII," para. 1: "evangelicae veritatis" "veritatis luce...originem traditionis dominicae revertatur".

${ }^{465}$ Cyprian, "Epistula LXIII," para. 1: "custodire traditionis dominicae veritatem".

${ }^{466}$ Cyprian, "Epistula LXIII," para. 19: "Religion igitur nostrae congruit....adque officio sacerdotii..."

${ }^{467}$ Cyprian, "Epistula LXIII," para. 1: "in Dominico calice miscendo, et offerendo custodire traditionis dominicae veritatem".
} 
sacrifice belongs to the processes of the tradition, rather than the tradition belonging to the sacrifice. The tradition sustains the truth that affirms the sacrifice therefore the sacrifice takes place according to the truth of the tradition. In this process "truth" is becoming traditionally identified.

Some quotes may begin to put the matter in perspective. The expression "tradition of the Lord" occurs at the beginning of the first paragraph "very many of the bishops who are set over the churches of the Lord by divine condescension, throughout the whole world, maintain the plan of evangelical truth, and of the tradition of the Lord". ${ }^{468}$ But while this use of "tradition of the Lord" is clearly treated as a collegially agreed priority, there seems to be no precedent for this use. The expression seems to have instituted the process which would eventually become the crisis of the nominalized tradition.

Therefore, sacrifice is sustained by the tradition, on the other hand, the tradition finds immense value in the sacrifice. Jesus, "our Lord and God", is described as "the author and teacher of this sacrifice". The sacrifice is the last supper offering of Jesus which he has passed down. Again, the basis for the tradition can be understood to be the imitation of the sacrifice. The element of sacrifice sustains a strong relational expression of truth. This is Cyprian's argument against those who use water rather than wine at the eucharist. "For if in the sacrifice which Christ offered none is to be followed but Christ, assuredly it behoves us to obey and do that which Christ did, and what he commanded to be done". 469

But the senses of identity and relationship in the tradition seem to combine to form an overriding sense of identifiable traditioning. Know then that I have been admonished that, in offering the cup, the tradition of the Lord must be observed, and that nothing must be done by us but what the Lord first did on our behalf." ${ }^{470}$ But what did the Lord first do on our behalf? With the words "for taking the cup on the eve of his passion" ${ }^{471}$ Cyprian demonstrates that the last supper sacrifice is what he first did on our behalf; "the tradition of the Lord" is the tradition of the last supper. Therefore, it is not only a sacrificial mimesis it is a traditional sacrificial mimesis, tradition governs sacrifice.

For Cyprian "the root and origin of the tradition of the Lord" is given in what "the founder and teacher of this sacrifice did and taught [concerning "this sacrifice"]. That is, after all, the

\footnotetext{
${ }^{468}$ Cyprian, "Epistle LXII," para. 1.

469 "Epistula LXIII," 2.

470 "Epistle LXII," 2.

471 "Epistle LXII," 9.
} 
purpose of this epistle; that those who use water and fail to show forth the blood of Christ, would learn to use wine, so that the blood of Christ may be shown forth in the pertinent sign. "if anyone is still kept in this error, he may behold the light of truth and return to the root and origin of the tradition of the Lord". ${ }^{472}$

Cyprian's reference to "the light of truth" in "the root and origin of the tradition of the Lord", brings into relief, the conjunction of historical and metaphysical horizons with which this thesis grapples. He conflates the historical, last supper, and transcendent "bread of life" origins of the Eucharist. In his defence, he does so through the intrinsically relational practice of "sacrificial imitation". But the sacrificially relational and traditional identified motifs in the imitation are not distinguished. Connected with this problem, Cyprian also conflates the historically identifiable and the transcendently relational senses of truth. Furthermore, he conflates the historically identifiable and the relationally non-identifiable senses of traditioning. To unsay these saids it is necessary to reflect more thoroughly on the history of traditioning.

\section{Tracing the Tradition}

Paul's first century use is clearly influential in Cyprian's reference to "the tradition of the Lord". His uses of the word group $\pi \alpha \rho \alpha ́ \delta o \sigma l \varsigma-\pi \alpha \rho \alpha \delta l \delta o ́ v \alpha l$ require considerable reflection; as do those of the Synoptics and John ${ }^{473}$. Paul introduced the question of reflective traditioning quite explicitly when writing to the Corinthians. There, at the beginning of Chapter 11 he praised the Corinthians for keeping "the traditions [ $\pi \alpha \rho \alpha \dot{\delta} \delta \sigma \iota \varsigma]$ he had traditioned $[\pi \alpha \rho \alpha \delta i \delta \omega \mu l]$ to them"474. Then, in the same chapter, at the beginning of his discussions of the eucharist ${ }^{475}$ he chastises them for their abuse of "the Lord's Supper" ${ }^{476}$ Clearly, compared to his "traditions" 477 this is something of a different status. "For I received from the Lord what [ö] I traditioned to you" "478

\footnotetext{
472 "Epistle LXII," para. 2.

${ }^{473}$ See chapter 1 , part B, section 4.

474 Cor 11:2.

475 Cor $11: 17$

4761 Cor 11:20.

477 Cor 11:2.

${ }^{478} 1$ Cor 11:23.
} 
It is significant that, in the pericope that recalls the last supper ${ }^{479}$ he used the verb "to tradition" ( $\pi \alpha \rho \alpha \delta \delta \delta o ́ v \alpha l)$ but not the noun, "tradition" ( $\pi \alpha \rho \alpha \dot{\delta} \delta \sigma \iota \varsigma)$, to speak of "what" (ó) he received $(\pi \alpha \rho \alpha \lambda \alpha \mu \beta \alpha \dot{\alpha} \omega \omega)$ and traditioned $(\pi \alpha \rho \alpha \delta l \delta o ́ v \alpha l)$ "from the Lord"480. His willingness to use both the noun "tradition" and the verb "to tradition" when referring to his own contribution, and his unwillingness to use the noun, when speaking of the contribution "from the Lord", needs to be read in light of the Septuagint's treatments of the word group ${ }^{481}$. It also relates to first century Christian uses not recorded in the scriptures: $\pi \alpha \rho \alpha \dot{\delta} \delta \sigma l$ was a name for informers, during Christian persecutions ${ }^{482}$.

These matters offer suggestions not only about Paul's but about all four Evangelists' uses of the word group $\pi \alpha \rho \alpha \dot{\delta} \delta \sigma \iota \varsigma-\pi \alpha \rho \alpha \delta \imath \delta o ́ v \alpha l$. At the very least they impose the consideration that, from the earliest moments of the tradition, the profound and complex word-group was not used thoughtlessly. Rather, it was treated according to its power to influence the ongoing lives of disciples. Therefore, when exploring third century practices it is necessary to be aware of the reflectively influential streams that flowed from as early as the first century into the third century environment.

Throughout the second century, references to the traditional character of Christian practices received concentrated attention. In about $180 \mathrm{CE}$, Irenaeus had introduced the expression "the tradition of the apostles" ${ }^{\text {"48 }}$. In doing so he both elevated and extended the sense of "tradition" ( $\pi \alpha \rho \alpha \dot{\delta} \delta \sigma \iota \varsigma)$ beyond the sense Paul had given it. He elevated it by applying it to the teachings and practices the Lord gave to the apostles. Paul did not combine "Lord" and "tradition". Furthermore, he only referred to his own traditions, not those of the apostles. Irenaeus' more reverential use was closer to the sense that Paul gave to the verb $(\pi \alpha \rho \alpha \delta 1 \delta$ óv $\alpha$ ) rather than the noun. Irenaeus' development shows the importance tradition was acquiring for sustaining the Gospel beyond the post-apostolic era. At the heart of this sense of tradition was the idea that the complete teachings of Jesus were available in scriptures and the tradition of the apostles. ${ }^{484}$.

About the same time as Irenaeus was writing, Tertullian of Carthage ${ }^{485}$ and Clement of Alexandria were also developing the idea of tradition. Therefore, the uses of "tradition" had

\footnotetext{
479 Cor 11:23-26.

4801 Cor 11:23.

${ }^{481}$ Cf above, chap. 2, part A, section 2, (d).

${ }^{482}$ Nodet and Taylor, The Origins of Christianity, 240-247. See especially footnote 117.

${ }^{483}$ Irenaeus, Against Heresies 3.3. For dating see, Irenaeus, The Demonstration of the Apostolic Preaching, 1.

${ }^{484}$ Irenaeus, Against Heresies 3.3.

${ }^{485}$ For "sacramentum" in Tertullian see Van Roo, The Christian Sacrament, 37.
} 
become diverse. The Latin, Tertullian, gave great importance to the traditional endurance of Christian and ethical sociality. ${ }^{486} \mathrm{He}$ not only spoke of the "tradition of the apostles"487 but also of "the tradition of one mystery ("sacramentum")"488. This Carthaginian "tradition of one mystery" prepares the way for Cyprian's one "tradition of the Lord". However, the progress towards Cyprian's use was also advanced by Clement of Alexandria, a North African scholar from a different and even more illustrious tradition than that of Carthage.

In (about 190) Clement of Alexandria exalted the sense of the noun "tradition" to its highest expression. He introduced the expressions "the divine tradition" 489 and "the tradition of the Lord". ${ }^{490}$ These expressions were very significant for Clement. They referred to the Gnostic's, involvement in a divinely breathed Gnosis. "For the life of the Gnostic, in my view, is nothing but deeds and words following in ( $\alpha \kappa o ́ \lambda o v \theta o \imath)$ the tradition of the Lord"491. This life of "following in the tradition of the Lord" had already been made available through the scriptures for anyone who sought the true gnosis; anyone who would "lend the ears of the soul" "492 to the reading of the scripture. For "the things delivered by the blessed apostles and

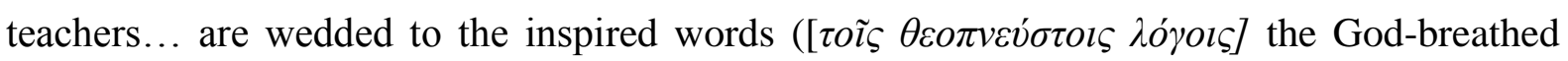
words") ${ }^{493}$. The point to Clement's teaching is that only the one who "lends the ears of the soul" ${ }^{\text {"494 }}$ to the scriptures, is able to receive more than the historically traditioned words. The historical words are necessary, for the things of God are wedded to them. They form part of the "God-breathed" gift. But, when the historical words are received without openness to their apophatic or God-breathed element, the scriptural words and canonical practices are not spiritually beneficial to the recipient. It is spiritual openness to the supra-historical elements that renders the Gnostic a recipient of "the divine tradition" 495 ".

It is worth noting that, in Clement's terminology, the "tradition of the Lord" is communicated

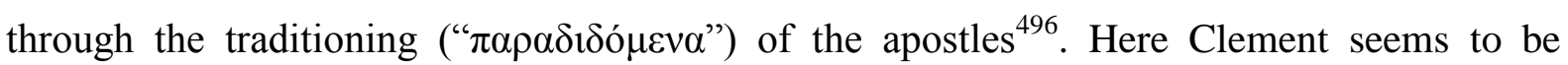
sustaining the exalted New Testament form of "traditioning" the things of the Lord.

\footnotetext{
486 Johannes Quasten, “Tertullian and 'Traditio'," Traditio 2 (1944), 481-484.

487 Tertullian, De Praescriptione Haereticorum, 21.

${ }^{488}$ De Praescriptione Haereticorum, 20.

${ }^{489}$ Clement, Stromata, 7.16.103.5.

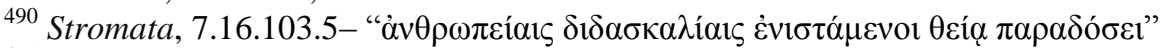

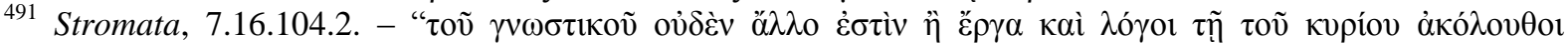
$\pi \alpha \rho \alpha \delta$ óøı."

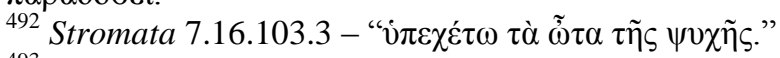

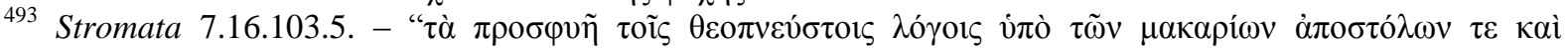

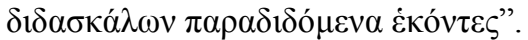

${ }^{494}$ Stromata, 7.16.103.3

495 Stromata 7.16.103.5.

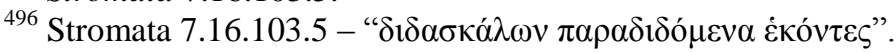


Comparing Paul's and Clement's terminology it may be said that Paul uses the verb ( $\pi \alpha \rho \alpha \delta 1 \delta o ́ v \alpha l)$ but not the noun ( $\pi \alpha \rho \alpha ́ \delta o \sigma 1 \zeta)$, when describing his apostolic part in the traditioning of the Eucharist. ${ }^{497}$ Similarly, Clement refers to the traditioning

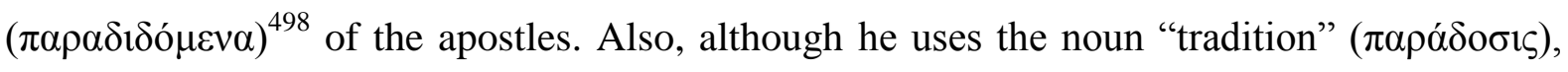
he exalts it above any sense that Paul gave it by forming the expressions "tradition of the Lord" and "divine tradition". This was possible given the new conventions relating to the noun at the time, conventions which for Paul would have been unthinkable ${ }^{499}$.

In a brief passage on the eucharist, in "The Pedagogor" 500 , Clement exhibits the affective logic of his arcane wisdom. The infant discerns the most purely communicated gift of meat, i.e. milk; for according to Clement's second century physiology, "milk is the sweeter and finer part of blood" ${ }^{, 501}$. He applies this logic of infancy because, according to Luke, Jesus applied it: "I bless you father ...for hiding these things from the wise and the learned and revealing them to infants." $" 502$ Therefore Clement writes, "Having reached this point we must defend our childhood". ${ }^{503}$ Then, prima facie he seems to contradict Paul's teaching on "milk" for the child and "meat" for the adult. ${ }^{504}$ He taught that the nurturing gift of the Father and Jesus in the Eucharist, is like a mother suckling her child. "The Word is all to the child, both father and mother and tutor and nurse. 'Eat my flesh,' he says, 'and drink my blood.' (John 6:53-54) Such is the suitable food which the Lord ministers, and he offers his flesh and pours forth his blood, and nothing is wanting for the children's growth."

According to this logic the novice and the learned both have preliminary and undiscerning attitudes to the milk of the Eucharist. On the other hand, the child who is born of eternal wisdom receives true nourishment. So Clement argues that the child of God, who is eternally born of God, has, in the blood of the eucharist, milk that surpasses the adult's meat. "We, believing in God, flee to the Word, the care-soothing breast of the Father, and he alone supplies us with the milk of love." 506

\footnotetext{
4971 Cor 11:23.

${ }^{498}$ Clement, Stromata 7.16.103.5.

499 The differences between Paul's Jewish adherence to the verb and Clement's Greek nominalization should not go unnoticed. They mark a turning towards identity. But that aspect of Clement is outside the scope of this study. The current reflections are concerned with the more prevalent relational elements in Clement's writing. ${ }^{500}$ Clement, Paedogogus 1.5.14.1 - 1.6.50.2.

${ }^{501}$ Paedogogus 1.6.39.2.

${ }^{502}$ Lk 10:21, quoted in Paedogogus 1.6.32.2.

${ }^{503}$ Paedogogus 1.6.34.3.

5041 Cor 3:1-3.

505 Paedogogus 1.6.42.3.

${ }^{506}$ Paedogogus 1.6.43.4.
} 
In Luke's Gospel, immediately after praising the Father for his revelation to infants, Jesus says "all things have been traditioned to me by my Father and no one knows the Son ..." This verse introduces two themes that were not developed in the discussion of the Eucharist in the Paedogogus. They are tradition-traditioning and knowledge. These are taken up in the Stromata. The above treatment of the Eucharist in the Paedogogus is necessary to demonstrate Clement's exceptional ability for unpredictable affective readings of the text. A look at "tradition" in the Stromata suggests that he found a way to unite the traditional and the exceptional.

The first occurrence of " $\pi \alpha \rho \alpha \delta i \delta \omega \mu l$ " in the Stromata is concerned with arcane traditioning. The secrets are traditioned secretly. ${ }^{508}$ This traditioning was not given by "the canon of tradition" "509 - which could also be called "the canon of the Church" - but "the canon of tradition," protects and serves as a kind of springboard for the elevated "tradition of the Gnostic". 510 The "canon of tradition" "prepares our ears for ... the tradition of the Gnostic" . 511 The traditioning of the secrets or mysteries is the way of the Gnostic's tradition. In this regard Clement also gives the highest esteem to "the traditioning of the apostles." Clement's strategies is particularly enlightening. He chains four uses of "tradition". Firstly, in Stromata 1:1 he introduces "the canon of tradition" tradition of the Gnostic" 514 . Then, in Stromata 7:16 he leads from the "tradition of the Gnostic" to the tradition of the Lord" "F15 "For the life of the Gnostic, in my view, is nothing but deeds and words following in the tradition of the Lord". ${ }^{516}$ Just prior to the reference to the "tradition of the Lord" he has named the source of all these gifts, "divine tradition" 517.

Chaining, these uses of "tradition" gives a perspective to all that is involved in "traditioning the mysteries secretly". 518 Similar to the difference between end and beginning, "divine tradition" in book seven contrasts with "the canon of tradition" in book one. Also similar to the merger of things

\footnotetext{
${ }^{507} \operatorname{Lk} 10: 22$.

508 “ $\mu v \sigma \tau \eta \dot{\rho} \rho \imath \alpha \mu v \sigma \tau \iota \kappa \tilde{\omega} \varsigma \pi \alpha \rho \alpha \delta i \delta o \tau \alpha l ” . ~ 1.1 .13 .4$.

509 “ $\tau \tilde{\eta} \varsigma \pi \alpha \rho \alpha \delta o ́ \sigma \varepsilon \omega \varsigma \kappa \alpha v o ́ v \alpha ” . ~ S t r o m a t a, 1.1 .15 .2$.

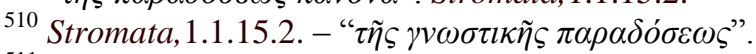

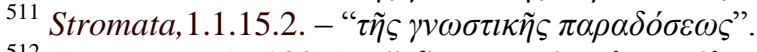

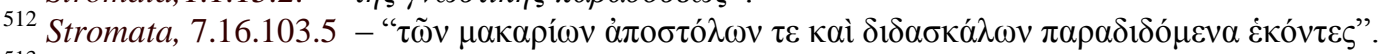

${ }^{513}$ Stromata, 1.1.15.2.

${ }^{514}$ Stromata, 1.1.15.2.

${ }^{515}$ Stromata, 7.16.104.2.

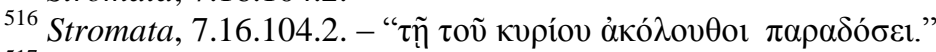

517 Stromata, 7.16.103.5.

${ }^{518}$ Stromata, 1.1.13.4.
} 
at the middle, "tradition of the Lord" in book seven combines with "tradition of the Gnostic" in book one. Without beginning in the canon of tradition the journey is impossible but without receiving "the divine tradition" the journey is meaningless. Without the Gnostic, following in and being formed in "the tradition of the Lord", it is impossible for the divine tradition to arrive on the earth. The Gnostic's practice of following the tradition of the Lord makes the Gnostic a participant in the tradition of the Lord.

Regarding the topic of wine or water at the Eucharist; like Cyprian, Clement also argued for the traditional practice of using wine not water in the eucharistic cup. "Those who use wine not water do not make the offering "according to the canon of the Church". ${ }^{519}$ But in doing so he did not conflate "the canon of tradition" with the "tradition of the Lord". Maintaining the logic that the low canonical tradition gives access to but cannot be identified with the divine tradition, he sustained the sense of a relational gnosis, in ongoing communication with the Lord. In this way he could convey a deeply affectionate sense of God in the sacraments and the scriptures.

Clement's distinctions, were not his invention. They were traditional. They were expressions of "the arcane discipline", the sense that the gifts of the liturgy could not be celebrated worthily in the presence of worldly observers. He simply reinforced the value of a high and low tradition. Applying teachings inaccessible through the letter of the text, he showed how the Lord celebrates and nurtures the infinite loveableness of his eucharistic child. In turn, the child is also able to celebrate her or his, infinite loveableness as a gift to the Lord. This is a tradition of rejoicing in the infinite passivity of the loveableness.

In the midst of this benign and elevated spirituality it is troubling that Cyprian should eliminate the distinction that prioritized the eloquence of the sacrament so highly. The eradication of the distinction is all the more perplexing since it was articulated for the sake of a matter on which Cyprian agreed with Clement, wine not water at the sacrament, according to the canon of tradition.

Therefore, Cyprian's reduction of two different kinds of tradition to one historically manifest tradition is difficult to grasp. In the first place, his sense of the historical event and tradition was radically pneumatic. He was not espousing the mundane institutionalism that has often taken root in the tradition of the Eucharist. In the second place, one comprehensive traditional horizon is impossible. The world always involves more than one horizon. Overt metaphysics, which is the discipline that holds together a plurality of horizons, would become increasingly influential in the determinations of the Eucharist. Therefore, the point may be made that he

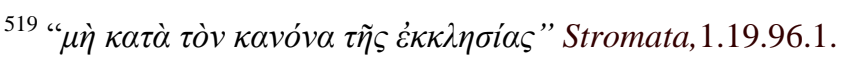


did not close up the tradition completely; Metaphysics still retained the sense of transcendence. But the sense of the relationality of the Eucharist had suffered a massive blow.

In the history of the tradition the sense of the related to still comes through. A mystic such as Catherine of Sienna can write "I have come to know, in the new creation you have made of me by the blood of your Son that you are in love with the beauty of your creature." ${ }^{, 20}$ It was her great gift to allow God to reveal her infinite loveableness to her. However, her influence has never become the norm. It comes from the other horizon; the unidentifiable horizon of relationship.

\section{The Hidden Revealed}

Looking back through the early histories of the Eucharist, it has become evident, that a sense of the Eucharist, based in the relational gifts of loveableness and being loved, has given way to a Eucharist concerned with the active retention of an identity. This is not entirely contrary to the sense of the Eucharist. The relational gift of loveableness is concealed in identity and the Eucharist is the symbol of 'God in hiding'. The mystery was still profoundly retained even though its understandings had been altered. Therefore, the idea of God hiding in the sacrament continued to be a cause for celebration. The horizons of the higher and the lower became horizons of the hidden and the revealed.

This new approach to the Eucharist was based in the sense that God is too immediately evident and communicative to be accessible through the representational senses. Here it seems that the sign involves two kinds of concealment. Firstly, there is the communicative gesture of concealment, through which the Eucharist goes to the heart of the communicant, like milk to an infant. This gift is not detained by the access through the representational senses. Secondly, there is the fallacy of imposed identity. The sign is understood in some incorrect way, and because it does not conform to that incorrect understanding, it is said to be hiding.

In the first part of the chapter, in the discussion of the Eucharist of the Beloved Disciple it emerged that eucharistic hospitability was formed by the sense of relationship. Given this evidence and the change in the sense of the Eucharist that accompanied Cyprian's definition, it may well be the case that the eucharist has been wrongly identified. But the Eucharist

\footnotetext{
${ }^{520}$ Catherine of Sienna, "Me in You, You in Me," In Teachings of the Christian Mystics, 121.
} 
cannot but be wrongly identified! It is not a sign of identity but of relationship. What would this mean? It means the quest to find the Eucharist is erroneous, but the willingness to be found by it is correct. It is not an identity to be found it is an expression of relationship to be accepted. Thomas Aquinas' famous poem exhibits this point well. It appears to be a prayer adoring a hidden identity, but the worshipper is overwhelmed by the immediacy of relationship that speaks through the sign. But the act of adoration becomes an overwhelming passivity of adoration and the hidden identity of the truth and the identity of Thomas play only the part the truth truly desires.

\section{Conclusion: Adoro Te Devote. ${ }^{521}$}

A premise to the "Adoro Te Devote" 522 is that the gift of the sign, or sacrament, is accepted based on the last supper words and gestures of Jesus, narrated in the Bible. There Jesus holds bread and then wine in his hands and says of each respectively, "this is my body", "this is my blood". The sign is therefore, profoundly relational and even the identity of the sign involves expressions of relationship that are unthinkable in terms of a nominal whatness of the sign.

In an expression of devotion that some hold to be too extreme, St Thomas Aquinas spoke to the sign in the second person singular and said -

"I praise you devoutly, hiding truth

You who are truly hiding under this form

Te devote laudo, latens veritas

te que sub his formis uere latitas

My heart submits itself to you completely,

because contemplating you it completely fails [deficit]"

\footnotetext{
521 Aquinas, "Adoro te Devote" from Opera Omnia, Corpus Thomisticum. English excerpts that follow are the author's translation of the Latin source text.

522 Aquinas, "Adoro te Devote"
} 
Tibi se cor meum totum subjicit,

Quia te contemplans totum deficit”.

"I believe what the Son of God has said.

There is nothing truer than this word of the truth"

"Credo quidquid dixit Dei Filius.

Nil hoc verbo veritátis verius".

"On the cross only God was hiding

But here humanity also hides"

"In cruce latebat sola deitas,

set hic latet simul et humanitas".

"Hiding truth" expresses the nominal identity of the sign. "Truly hiding" expresses the infinite relationality of the sign. Here, Thomas declares that he worships the sign because the sign is Jesus-God in disguise. His identity is lost to human cognition. Similarly, Thomas is lost in powerlessness. Even though there is a strong sense of the identity of God in the sacrament, the sign's power to conceal that identity produces the relational language of love in Thomas' song of praise. It begins with the astonishing surrender and weakness in communing mysteriously with the Eucharist.

Before this hiding-lurking truth, the 'how' of the relationship is the issue. How does the hearer of this word relate to its sign? "My heart submits itself to you completely, because contemplating you it completely fails (defecit)". The hymn goes on to celebrate the way mortal powerlessness turns into life through this relationship.

So, Thomas continues to celebrate the meeting and his lostness in it. It is the relational, not the identifiable life of Jesus - and not the identity, but this new relational life of Thomas that Thomas desires. Thomas desires it because of his confidence that Jesus desires it. The hymn celebrates a relationship of faithful desire which Thomas taught to be the only condition necessary for the reception of the sacrament. ${ }^{523}$

'Make me always believe you, have hope in you, love you more and more'

\footnotetext{
523 "sicut ex fide Ecclesiae credunt, ex intentione Ecclesiae desiderant Eucharistiam, et per consequens recipiunt rem ipsius."
} 
"Fac me tibi semper magis credere,

In te spem habere, te diligere"

The sign binds the themes of death and resurrection. The bread is "living"!

"O memoriale mortis Domini

Panis vivus, vitam præstans homini!"

In addition, through this dynamic of death and resurrection the hymn goes on to pray for and celebrate the transformation of this overwhelming hiddenness into in an infinitely more overwhelming revelation.

"Allow me always to live from you

and always sweetly know you"

"Presta mihi semper de te vivere

et te mihi semper dulce sapere"

"Jesus whom I now glimpse veiled,

I pray, do what I so desire:

That, seeing your revealing face,

I may be blessed by the vision of your glory.

Amen"

"Jesu, quem velatum nunc aspicio

Oro, fiat illud quod tam sitio:

Ut te revelata cernens facie,

Visu sim beátus tuæ gloriæ.

Amen" 524

Clearly, there is a question of knowledge. The new knowledge will arise through the species of sweetness. Although there are questions of identity to be discussed, this text is not

${ }^{524}$ Aquinas, "Adoro te Devote" 
concerned with "what this sign says about the state or nature of God?" This is not a study of the sign it is a conversation with it and it is made even better by the fact that one of the parties to the conversation, the sign, is immensely silent! 


\section{Chapter 3}

\section{How the Eucharist Temporalizes: A Phenomenological Description of the Eucharist}

\section{Introduction}

This chapter argues that the Eucharist is a sign of consecrating relationality or unconditional loveableness. It is in four parts. Part A introduces basic concepts through which the relational temporalisation of the Eucharist can be understood. Part B shows how the relational temporalisation of the Eucharist has been evident throughout its history. Part $\mathrm{C}$ shows that this relational temporalisation is so profound that it grounds the meaning of the metaphysically identifying Eucharist of the high Middle Ages. Part D provides a description of the Eucharist as a sign of consecrating relationality or unconditional loveableness.

The chapter will explore the temporalization of the Eucharist through a process of literary reflection. Part A is a brief prolegomenon. It clarifies some necessary concepts for a temporal and relational understanding of the Eucharist. Part B will research biblical and liturgical eucharistic texts because of the temporal elements they exhibit. The exhibition of temporality in the texts is clearly evident. Nevertheless, many of the simple temporal processes within the liturgies need to be pointed out. Part C explores Thomas Aquinas' passages on transubstantiation and his last teaching on the Trinity. At the basis of these texts on transubstantiation and on the unchanging identity of God, a profoundly temporal and relational dynamic is at work. Part D unites Thomistic and Levinasian thought with Jeremias' theology of anamnesis to provide a phenomenological description of the Eucharist. Rather than describe the Eucharist as the achievement of the victorious ending, it treats it as the bestowal of an inexhaustible beginning. 
This chapter differs from the previous chapters. They explored the ways relationships structure the Eucharist. Chapter one described its roots in the relational sense of the covenant meal. Chapter two showed how its history witnesses to difficulties and solutions in the concurrence of relationship and identity in the Eucharist. This chapter demonstrates how the relational and identifying senses of the Eucharist can be reconciled through a phenomenological understanding of this traditional sign. The challenge is to describe how the Eucharist (a liturgical celebration) signifies traditionally. This approach differs from that taken by Marion in God without Being ${ }^{525}$, where Marion describes the Eucharist as the immediacy of pure Givenness. Marion's contribution is valuable but it does not explore the historical relationality of the sign. If its temporality is not given traditionally, it is not given at all because the Eucharist only exists as a traditional sign. Rather than establishing the sense of the Eucharist through the intuition of the unconditional Gift, this thesis examines its sense on the basis of the historical fact that it is traditioned. If the Eucharist signifies as Gift given to the unconditional openness of pure intuition it cannot do so without also figuring as a traditional historical phenomenon. Therefore, the Eucharist cannot be defined on the basis of intuition alone. This thesis explores the sense of the Eucharist that arises when it is treated according to some of its diverse historical expressions. It does not explore the Eucharist as an expression of faith-intuition or of metaphysics but as an expression of traditioning.

Recognition of the Eucharist as an expression of traditioning is a new approach. Therefore, this chapter begins with a presentation of some concepts basic to the idea of traditioning. While the previous chapters have contributed to this preparation, some more observations are needed before the traditioning of the sign can be directly explored. Having introduced a basic sense of relational traditioning in Part A, the following questions structure the remainder of the chapter:

How does the sense of time contribute to the meaning of the Eucharist?

What sense does relationality contribute to the consecrated identity of the Eucharist?

How does relational consecration come to expression in the Eucharist?

The prolegomenon, Part A, and these three questions exhibit the agenda for this Chapter. Part A clarifies the basic concepts. Part B sketches the temporal processes through which the Eucharist has come to signify throughout its history. It shows how temporality and

\footnotetext{
${ }^{525}$ Jean-Luc Marion, God without Being: hors-texte. Marion's Phenomenology is discussed in pages 36-39 of this thesis.
} 
relationship are bound together in the sign. Part $\mathrm{C}$ examines the strongly identified doctrine of transubstantiation, as given by Thomas Aquinas ${ }^{526}$ and argues that, at its most profound level (the level of consecration), this doctrine describes the Eucharist as a radically relational sign. Encouraged by the evidence from the late writings of Saint Thomas and its compatibility with Levinas' relational phenomenology, Part D provides a description of the Eucharist based in Levinas' relational phenomenology and Jeremias' exegetical presentation of the biblical theology of remembrance.

To respond to these matters, texts have been chosen in which the distinction between identity and relationship can be clarified and the relational dynamics of the sign can be discerned. In the first three parts of the chapter, certain figures show the value of the distinction. In Part A, the witness of Joseph of Egypt is invoked to show how a concealed identity contributes to the communication of a beneficial relationship. In Part B, Paul's distinction between liturgical traditioning (1 Cor 11:23) and narrative traditioning (1 Cor 15:3) shows how the traditioning of the sign and the traditioning of a narrative differ. In Part C, Thomas' texts on the Eucharist (Summa Theologica 3.75) and on the Trinity (Compendium Theologiae 1.45-46) show that even at its supreme expression, the sense of identity in the Eucharist is based in the sense of relationship. Rather than demonstration through figures, Part D is bound to advances in contemporary philosophy and biblical exegesis. Therefore, it adds observations from Levinas on relationality in Otherwise than Being or Beyond Essence and on Eucharistic anamnesis from Jeremias to advance the sense of the relational temporalization of the Eucharist which emerged through the previous three sections.

\section{Part A: Basic Concepts in the Traditioning of the Eucharist}

This part discusses low-Christology and the origins of the Eucharist, temporalization, canonization, traditioning, identity and relationship.

\section{Low-Christology and the Origins of the Eucharist}

The Eucharist first emerged as a pragmatically sustainable but theoretically incomprehensible signifier. It was not developed on the basis of theoretical insights. Pragmatically, it was concerned with covenant relationships rooted in the ministry of Jesus.

\footnotetext{
${ }^{526}$ Aquinas, Summa Theologica 3.75 is specifically concerned with transubstantiation but the complete passage on the Eucharist is 3.73-78.
} 
Not only did it lack doctrinal identification, but it came to expression amidst a diversity of social environments. This diversity was significant enough to find expression in the scriptures, even to the point of conflicting evidence. Remarkably, John's Gospel has Jesus celebrate the Eucharist on the eve of the Passover meal, while the Synoptics have Jesus celebrate the Eucharist at the Passover meal. The evidence of this discrepancy demands awareness that the eucharistic biblical narratives were written to endorse traditional practices rather than compose historically accurate accounts. Therefore, an initial historical question is, how are the traditions and the literature related?

On this basis, the following may be said about the historical origins of the Eucharist. The Eucharist forms part of a history of practices and narratives that began with the ministry of Jesus and achieved a transformed significance due to his death. Of the various historical episodes, the eucharist is overwhelmingly influenced by his death. This is reflected in the words that begin and end Paul's pericope on the Eucharist. It begins, "The Lord Jesus, on the night he was handed over [ $\pi \alpha \rho \varepsilon \delta i \delta \varepsilon \tau o]$ took bread,"527 and it ends, "for as often as you eat this bread and drink this cup you proclaim the death of the Lord until he comes". ${ }^{528}$ In the formation of the Eucharist the influence of the death of Jesus has been so significant that de Jonge considered it to be the starting point of the Eucharist, and that there were no significantly eucharistic meals before the death of Jesus ${ }^{529}$. But the dismissal of the meal practices of Jesus prior to his death has to argue against strong evidence that Jesus did maintain meal traditions with his disciples and that those meals were accepted into the Eucharistic traditions formed after his death. The evidence is based in the strong interconnections between the general meal narratives and the eucharistic narratives about Jesus. This applies especially to his revolutionary table practices. ${ }^{530}$

Nevertheless, de Jonge's theory emphasizes the valuable point that the majority of Eucharists did not originate in the Jewish culture. The Eucharist was exported with lightning speed into different cultures and meal traditions. The Apostle Thomas may have gone as far as India, probably within the first twenty years of the apostolic diaspora. ${ }^{531}$ In these cultures the Jewish

\footnotetext{
527 Cor 11:23.

5281 Cor 11:26.

${ }^{529}$ Henk Jan de Jonge, "The Community Supper according to Paul and the Didache: Their Affinity and Historical Development," 30-47.

${ }^{530}$ Cf above, chap. 1, part B, section 2-3, p. 63-80.

${ }^{531}$ Johnson Thomaskutty, Saint Thomas the Apostle, 206-7.
} 
meal traditions were unknown, therefore it was necessary to adapt the Eucharist to those meal practices. This places the first eucharists in a world of diverse meal environments and gives rise to a basic question ${ }^{532}$. Given the diversity of meals, what made some meals eucharistic and others non-eucharistic? It cannot have been the meals themselves. It must have been a eucharistic element which was identifiable across those meals. This leads to a related question: how much was the Eucharist a discrete entity? Was the "eucharist" a liturgical moment that could be distinguished from the rest of the meal and celebrated among various types of meal? There is the possibility that there was a distinguishing moment at the beginning of the meal. This conforms to the traditional Jewish practice ${ }^{533}$, and the widespread habit of beginning a meal with a prayer of thanksgiving. Luke 22:14-20 reflects two eucharistic practices. One tradition (17-19a) was almost certainly the earlier than the other $(19-20)^{534}$. The earlier tradition has the eucharist at the start of the meal ${ }^{535}$ while the later has it during the meal ${ }^{536}$. The former practice is consonant with the most common Jewish practices, the latter suggests new developments in the tradition. The main point is that a eucharistic element did become distinguished. What was its significance? How did it arise?

With regard to discerning the discrete element, 1 Corinthians 11:17-34 is informative. It inserts a pericope modelled on the last supper (verses 23-26) The discrete element is a recollection of the night Jesus was handed over, an account of his words and actions relating to bread and wine, and an apocalyptic saying about the significance of this liturgical symbolism at the meal. This shows that from an early stage the sign quickly became referred to as "the body" and "the blood" of Jesus. It was bound to the remembrance of his death. But how did this come about?

The Jewish and gentile elements need to be accounted for differently, as do the pre- and postcrucifixion elements. However the consensus of authors in a large spectrum that ranges from Nodet and Taylor ${ }^{537}$, to de Jonge ${ }^{538}$, emphasizes an important generic element. All the eucharistic meals involve a strong narrative content.

\footnotetext{
${ }^{532}$ Paul F Bradshaw and Maxwell E. Johnson, The Eucharistic Liturgies: Their Evolution and Interpretation, 124.

${ }^{533}$ The Eucharistic Liturgies, 1-14.

${ }^{534} \mathrm{Cf}$. Nodet and Taylor, Origins of Christianity, 110-116.

${ }^{535}$ Lk 22:15-18.

${ }^{536}$ Lk 22:19-20.

${ }^{537}$ Nodet and Taylor, The Origins of Christianity.

538 de Jonge, "Community Supper", 39.
} 


\section{(a) Jewish Meals}

Attending to the Jewish issues there are specific factors to consider: During the ministry of Jesus there was a tradition, or there were traditions, of liturgical meals which had an integral narrative content concerning Jesus. These parts were discussed in chapter one although the matter of temporality is added here. This includes the "Day of the Lord," the comprehensive day of his coming. The Didache tells us that this celebration is to be held "on the day of the Lord" ${ }^{339}$. Therefore, it is celebrated on a day which comprehends all time. This means that contents from meals that celebrate various times can be included in the Eucharist.

Four factors in the temporal designation of this liturgical meal render it capable of absorbing elements from various sources. Firstly, as noted above, it celebrates the fulness of time and can therefore include elements from meals pertaining to various points in time. Secondly, it has strong links with the Todah meal. This includes historical and apocalyptic horizons. These horizons provide the opportunity to produce thematic organization from the Passover (historical) and Pentecostal (apocalyptic) meals. It is also a very simple liturgy which can be attached to another meal such as the Sabbath meal. Thirdly, the meal celebrates Jesus and therefore is able to draw on the various meal practices that he observed during his public ministry. Therefore, there is no need to establish one formative meal but to recognize the contributions that come by way of the various liturgies. However, as Gese shows, an emphasis on the tradition of the Todah meal facilitates a flexible approach. Finally, the most important contribution that comes from the Jewish meals is that they are covenant meals. This is strongly expressed not only in the last supper blood references ${ }^{540}$ but also in the words over the cup without the blood reference ${ }^{541}$.

Jesus was a minister of covenantal relationships. This cannot be eliminated from his meal practices. The covenantal emphasis of his life was at its strongest through his death and resurrection. Therefore, the meal occasioned by his death and resurrection had exceptionally strong covenantal value for his disciples. The Todah was liturgically occasional. Whether or not the last supper was a Todah meal, the occasion of thanksgiving prior to the death and resurrection of Jesus, and the great Thanksgiving after it were liturgically provided for to perfection, by the elements and thematics of the Todah meal.

${ }^{539}$ The Didache, 14.

${ }^{540}$ Mt 26:28, Mk 14:24, Lk 22:20, 1 Cor 11:25.

${ }^{541}$ Lk 22:18. 


\section{(b) Gentile Meals}

The gentile meals would have been similar to the Jewish meals. They involved thanksgiving and had a strong accompanying narrative, or, when not narrative, philosophical element. However, these narrative and discursive contributions were not as rich in thaumaturgical and apocalyptic narratives as the Jewish meals. They were also foreign to the Jewish covenant narratives in which the Christian narratives had been grounded. They were not covenantal and the theme of gratitude did not involve the pathos provided by the Todah and Passover liturgies. Therefore, the challenge for the evangelists to the gentiles was great. How to impart the depth of the Jewish liturgical and literary traditions to people who were not versed in its ways.

Paul's solution was to "preach Christ and him crucified"542. Therefore he distinguished between 'traditioning his own traditions" 543 and 'traditioning...from the Lord' Furthermore, the content received from the Lord was rich in eschatology. It recalled the death and return of the Lord $^{545}$ and it was celebrated in a thanksgiving ${ }^{546}$. This shows that Paul distinguished a Christological liturgical element, the element that sustained "the remembrance" of Jesus at the meal ${ }^{547}$. Whether this was a liturgical formula or a guide is not significant. The important point is that the topic of remembrance is evident in Pauline and Synoptic accounts of the last supper. Remembrance was clearly a shared motivation for the celebration of the eucharist. In the Jewish environment, the last supper mimesis became the predominant meal narrative at the liturgical meals. This same priority was brought to the gentile symposia. ${ }^{548}$ Paul's instructions to the church at Corinth show that it was not necessary to change the kind of meal, but that it was necessary to ensure that everyone was sharing in the meal and to retain the saving eschatological element that the Jewish eucharists celebrated. The saving revelation of Jesus, witnessed in the Jewish meal traditions, could be imparted if the anamnetic character of the last supper mimesis could be sustained. What was that anamnetic character? The memorial ( זֶֶר ) element of the liturgical meal. It was not only the narrative of the death and resurrection of Jesus it was also the liturgical gift of the

\footnotetext{
5421 Cor $1: 23$.

543 Cor 11:2.

5441 Cor 11:23.

5451 Cor 11:26.

5461 Cor 11:23.

5471 Cor 11:24 - 5.

${ }^{548}$ The Eucharistic Liturgies, 1-3.
} 
thanksgiving sign. The thanksgiving sign brought the narrative into a moment of existential reflection.

This involved the commandments to practice social justice. In 1 Cor 11:23-26 Paul invokes the Easter narrative of the last supper to admonish the Corinthians to maintain Jesus' ethos of social justice. It expresses the need for a shared meal, which is the necessary ethos at the "Lord's Supper" ( $\kappa \nu \rho \imath \alpha \kappa o ̀ v ~ \delta \varepsilon i \tilde{\pi v o v)}{ }^{549}$. But it is not enough to describe the Pauline passage simply in terms of a pragmatic ethos of social justice. A simply pastoral interpretation of the supper reads validly for the passage from verses 17-22. But this non-liturgical definition becomes questionable when Paul introduces the institution narrative of the last supper in verses 23-25. It becomes impossible once the eschatological tones in verses 26-34 arrive.

Once the passage is read as a whole it becomes evident that a sense of "crisis" pervades verses 17-34. Paul is calling for a table ethos which celebrates the eschatological gift of Jesus. This is evident in its name, the "Lord's Supper" (verse 20). It is also evident in the pericope on the last supper (verses 23-26). In all the eucharistic last supper texts, the institution narratives are bracketed by a declaration of betrayal ${ }^{550}$ and an apocalyptic proclamation $^{551}$. In Paul's case the apocalyptic saying is "as often as we eat this bread and drink this cup we proclaim the death of the Lord until he comes" Finally, the eschatological power of the gift is evident in the change of content that transpires between the passage that precedes the pericope and the passage that follows it. Following on from the eschatological pronouncement, verses 27-34 give eschatological reasons for Paul's insistence on social justice ethics at the last supper. ' $\kappa \rho$ í $\mu \alpha$ ' and other forms of 'judgment' abound in these verses. It is important to appreciate, whence Paul's sense of the supper gets its eschatological force and the last supper pericope makes it quite clear. The eschatological sense of the supper is based in its traditional proximity to the death of Jesus. The death of Jesus is directly referred to at every stage of the last supper pericope.

But this does not make the last supper the only source to the meal tradition. The traditional celebration of the last supper would not have its early significance if there were not already a tradition of celebrating meals in relation to Jesus. Therefore, it seems most likely that the Galilean meal practices of Jesus would be the chronological and logical source of the Eucharist. However, they could not be the only influences because his own ministry was not

\footnotetext{
5491 Cor 11:20.

${ }^{550}$ Mt 26:21, Mk 14:18, Lk 22:21, 1 Cor 11:23

${ }^{551}$ Mt 26:29, Mk 14:27, Lk 22:15-18, 1 Cor 11:26.
} 
restricted to Galilee, and because Christianity took root in diverse cultural environments. Therefore, the Galilean "breaking of bread" was celebrated, or modified according to its various cultural environments. In addition to these developments it seems most probable that the Johannine community abandoned the Eucharist at the time of the Second Edition. ${ }^{552}$

With this plurality, some important information is imparted by saying that the disciples gathered to remember Jesus. The processes through which the handed down literature was established show that canonization was deemed necessary for the ongoing community. The same principle of canonization also applied to traditional practices, such as the liturgical meals. Did this mean the Eucharist was being identified? Pragmatically, this gradually proved to be the case. There was an emphasis on remembering Jesus through recalling the last supper. But the pragmatic identity of the meal and its theological identity are vastly different kinds of identity. The pragmatic identity involved diverse groups of people who found it necessary to make distinctions between faith and cultural determinations of the meal. It was found that the determinate symbols of bread and wine could be expressed in a variety of meal environments but it took some time for this to be established. Contemporary scholarship is indecisive about how influential Jesus was at the early stages. However, he was influential. The ways he was actually influential, and the ways he was deemed to be influential may have differed to some degree, but Jesus is clearly at the beginnings of the tradition.

(c) The Formation and Significance of the Last Supper Tradition

The four Gospels have Jesus performing the miracle of the loaves and fishes. There they show him giving thanks and sharing in ways similar to his practice as described in the Synoptic last supper narratives ${ }^{553}$. These correspondences, plus the many gospel passages which have Jesus at table, indicate important meal traditions that have their roots in the words and practices of Jesus. Not only that, Jesus' meal practices were based in strongly established Jewish traditions. Prior to the time of Jesus, the Sabbath, Pentecost, Todah and Passover meals were all particularly important for the formation of the tradition. More important again is the fact that narratives and teachings were shared at these meals. Prior to the introduction of the words "do this in memory of me" the meal practices, narratives and teachings of Jesus were already pragmatic expressions of remembrance. "Do this in memory of me" could

\footnotetext{
${ }_{552}$ Von Wahlde, The Gospel and Letters of John, 550-552

${ }^{553} \mathrm{Mk}$ 8:6 and Mk 14:22.
} 
hardly be said to bring a new motive into the traditioning of the sign. It arrives in Luke's and Paul's last supper narratives by way of endorsement, clarification and canonisation.

Another important factor is that the meals were a focal point for community building decisions. The decision to practice generous hospitality was radically formative of the tradition. The Gospels portray decisions made by Jesus, to honour all kinds of outcasts: moral (the woman with a bad reputation, Luke 7:36-48), economic (the poor, Luke 14:13) and political (tax collectors and publicans, Luke 19:2-10). These not only display repeated practices but also formative decisions. Meals were decisive in establishing the kind of fellowship that formed the tradition. This was not exclusive to the communities of Jesus. Many communities accepted liturgical meals as ways of establishing their identity and sustaining their common life. Similarly, where there were crises in the common life, this would easily show at meals. However, there is a certain definitive element of crisis in the accounts of the meals of Jesus.

The last supper narratives exhibit the value of the meal as a literary resource; it provides a forum in which the social dynamics of the community can be displayed. In the first place, significant social content manifests itself at meal time. The last supper and other meal narratives exhibit Jesus as one who celebrates covenant bonds at meals. Secondly, that which belongs outside the meal can still be exhibited at the meal table. According to the texts, Judas' acts of betrayal did not happen at the meal table, they happened away from the meal table. ${ }^{554}$ Yet, their emotional significance is most clearly expressed by reflecting on the impact that the betrayal has in the environment of the meal. Hence Judas leads an ineffective mutiny ${ }^{555}$ at the penultimate meal in Matthew's and John's Gospels and Jesus predicts his betrayal by Judas at the ultimate meal. These turns of events are feasible but, the altercations between Jesus and Judas could have taken place outside the forum of the meal. Doubtless, the issues were not restricted to the dinner table. It is also quite likely that a prophetic teacher such as Jesus would articulate the vital issues at an event as significant as a meal, especially as he sensed that his life was acutely threatened. But stepping back from the historical arena to the perspective of the dramatist, the meal provides an exceptionally helpful emplotment (l'intrigue ${ }^{556}$ ) through which the historical dynamics in the community may be conveyed.

\footnotetext{
${ }^{554}$ Mt 26:14.

${ }^{555}$ Mt 26:8-9; John 12:4-6.

${ }^{556}$ Use of emplotment [l'intrigue] reflects Ricoeur's theory that emplotment is at the basis of both historical and fictitious narratives, see Time and Narrative.
} 
If the points are taken that the conflict with Judas was ongoing and that the liturgical meal tradition was ongoing, it is easy to read the last supper as a forum in which a number of diachronic elements may be captured in the synchronic parameters of one narrated event. In many ways, the last supper narratives reflect sustained meal practices and meal environments that Jesus shared with his disciples. This assertion may be strengthened and discussions about an actual historical last supper may be profitably advanced. However, that is not a necessary preliminary point of discussion. The crucial point, and - for the sake of a phenomenology of the Eucharist - the adequate point is that meals are dramatically empowered social environments in which the dynamics of diachronic relationships find expression. This is the case, a fortiori, when the meals are liturgical. Jesus, an established prophet, did share liturgical meals with his disciples. The social dynamics at those meals were revolutionary and at times full of conflict. The deceitful practices of Judas, which Jesus knowingly encountered, were emotionally active in the environment of the meal. Doubtless Jesus confronted that deceit, not as a politician trying to salvage his authority, but as a prophet seeking the way God was calling him and is disciples, including Judas, through this crisis. He would have almost certainly spoken about it to Judas. He also had various sources of knowledge, the Gospels give Nicodemus and Joseph of Arimathea as friends in the Sanhedrin. He knew Judas well over a period of some years. He was exceptionally gifted in reading the hearts of people and at reading and accepting the possibilities in situations, for good or ill. It would have been part of his vocation to pray through these matters and express them to at least some degree at least one community meal. The four gospel last suppers agree that Jesus predicted his betrayal while concealing the identity of the betrayer. Mark's narrative has Jesus aware of his imminent betrayal not only to the point of praying for deliverance, "let this cup pass from me" ${ }^{, 557}$. But also to the point of wanting to escape. "Let us go, my betrayer is near at hand.,"558 These narrative elements present a last supper scene in which Jesus was emotionally and spiritually convinced about his impending betrayal and death. According to Gese, this moment of betrayal made the last supper a sacrificial meal ${ }^{559}$.

Beneath these references to the one meal, it emerges that the last supper accounts involve idealized elements. It almost certainly includes elements from more than one meal because the tradition read the liturgical meal practices of Jesus as covenant meals, and above all as meals of covenant thanksgiving. The tradition recounted the last supper in an exceptional way

\footnotetext{
${ }^{557}$ Mk 14:36.

${ }^{558}$ Mk 14:42.

${ }^{559}$ Conf. Gese, “Origin”, 137.
} 
because it manifested the depth to which Jesus surrendered his life in celebrating covenant meals. Through his last meal more than any other, the tradition found in Jesus his sacrificial character, his pervasive expectation of the resurrection, and his respect for the bond between sacrifice and meal in the Jewish tradition. The particulars about an individual meal are ineradicably engraved in the post-crucifixion tradition. But those particulars also merge with other meals. Through the sense of the meal they refer to the prayerful offering of a person's life, Jesus' life, to God's salvific love, for himself, his community and their mission.

A final point concerns the ability of a meal to portray diachronic dynamics within synchronic parameters. The ongoing tensions and distrust about traditioning and betrayal in the persecuted communities of the early church are also powerfully expressed and developed in the last supper accounts ${ }^{560}$.

\section{Temporalization}

If all events were in a single present, there would be no temporalization. All events would be synchronic. Temporalization arises because events are also diachronic. Every event involves a past and a future, and therefore a diachronic temporality. Diachrony can be ontological. Events go through individual diachronic processes. Relationships are intrinsically diachronic because the temporal horizons between two unique beings differ - they cannot be completely synchronized. Because the topic of temporalization pervades this thesis, it needs to be introduced here not for the sake of a complete description, but to clarify the ways it is at work in these studies.

At the basis of the Eucharistic sense of time is the resurrection. The expression resurrection has already been used in this thesis, it is now time to say what that means. Understood in terms of faith assertions, the resurrection can be treated ontologically. The being Jesus, who died, is raised up after his death - his being is restored to him. Although this is an acceptable expression of faith, it is not what resurrection means in terms of phenomenology. Phenomenologically, resurrection is a relational, rather than an ontological, signifier. It refers to the indestructible relational significance of an individual, in this case, Jesus. A phenomenological account of the resurrection must articulate the ways in which the relational sense of Jesus' life exceeds the limits of his death. Because his disciples continue to grow in

${ }^{560}$ On this point, see Nodet and Taylor, Origins, 117 and 244. 
the sense of relationship with Jesus, it is meaningful to describe the resurrection in terms of relational significance.

The exploration of this relational sense is enhanced by the importance of food in the resurrection narratives. Meals figure prominently among the resurrection narratives, along with the post-resurrection sections on the Eucharist at the end of John's Gospel and the late Markan ending. ${ }^{561}$ In Luke and John there are three further resurrection narratives, at which Jesus reveals himself through a meal. ${ }^{562}$ This prioritizing of the way Jesus relates through food has obvious connexions with the Eucharist. Clearly, in these resurrection appearances, neither Jesus nor the disciples meet because of an ontic need for material food. They meet at meals because, like the resurrection, food not only has ontic value, it also has a relational value. Food temporalizes ontologically and relationally.

These comments introduce the fact that the Eucharist is a profound sign which involves identity, ontology, signification, death, relationality, and all kinds of incomprehensible expressions of the meaning of time. They cannot be covered in these brief comments, or even in the whole thesis, but they raise the point that the Eucharist concerns immense horizons of temporal meanings and possibilities. With these observations, it is possible to return to this historical study of how relational temporality pervades the Eucharist.

The crisis through which the liturgical meal had unfolded and the astonishing sense of the resurrection through which it had been revived introduced restless and creative dynamics into the ongoing tradition of the Eucharist. For some years (the three Passovers in John's Gospel $^{563}$ indicates more than two years), Jesus had expressed his religious relationship with his disciples through the meals they celebrated together. But what became known as "the last supper" had inestimably greater significance than the previous meals. Retrospectively, it was the meal in which the relational bonds Jesus formed with his disciples had reached their most significant and most traumatic expression. Because of the intense trauma and significance of the days and hours surrounding the meal and following the crucifixion it is reasonable to expect a high degree of thematization and idealism to emerge through its recounting. It was Passover week, a week involving the great liturgical meal of the Passover.

There is a question about whether the last supper was a Passover meal or a different meal. This question remains unresolved. Jeremias argued that the last supper was a Passover

\footnotetext{
${ }^{561}$ Jn 21:15-19 Mark 16:14

${ }^{562}$ Lk 24:28-35, 24:41-43, Jn 21:1-14,

${ }^{563}$ Von Wahlde, The Gospel and Letters, 2:228.
} 
meal ${ }^{564}$. Since then, Nodet and Taylor have argued that it was not a Passover meal. They have a number of reasons for disputing the Passover meal theory and make the following observations: (i) "In the way the meal is described, the insistence on bread and wine does not fit easily into a Passover setting" 565 (ii) "the rite of bread and wine... has connotations of Pentecost" "566. (iii) The symbolic use of bread and wine is "habitual" but it is not a main symbolic element in a Passover meal ${ }^{567}$. (iv) Therefore, two very different meal traditions are linked. A Pentecost meal tradition involving the easily repeatable use of bread and wine, with the simple eschatological symbols of first fruits and a complex Passover meal setting. The simple symbols "have been inserted into the unique and unrepeatable drama of the death of Jesus, for which the Passover setting announces the failure of one Messianism and the promise of another". ${ }^{568}$ (v) "Behind the account of the last supper there is indeed a liturgical tradition which is independent of the Passover" ${ }^{259}$. These are strong arguments for a nonPassover last supper but more importantly, also it establishes the diverse influences involved in the formation of the Eucharist. To these influences - Pentecost, Passover and Sabbath - it is necessary to add the Todah meal.

The fact that these discrepancies are in the canonized text shows that the scriptures were written to sustain a sense of the meaning of the Eucharist, rather than a report on its historical details. The historical identification of the meal was secondary to its value in communicating a sense of relationship with Jesus. But this unreliability on historical details does not render the meal a pure idealization.

The valorising of idealization and thematization is a fallacy. However cognitively disturbed a traumatized memory may be, a trauma is not a product of the imagination. Historical events produce traumas. Therefore, however thematised and idealized the meal may have become, the recollection of the meal had its roots in historical events. It transpired that after the meal Jesus had been betrayed and arrested. Judas, was perhaps assumed, perhaps known, to be the betrayer because through these events he distanced himself radically from the disciples. The narratives even have him accompanying the arresting cohort. Whatever his attendance at the meal that night, he was part of the group of disciples, he would normally have been there. And, it was later discovered, that he (whether present in absentia or not) was hypocritical.

\footnotetext{
${ }^{564}$ Joachim Jeremias, The Eucharistic Words of Jesus, 41-62.

${ }^{565}$ Nodet and Taylor, Origins of Christianity, 110

566 Origins of Christianity, 116

567 Origins of Christianity, 117

${ }^{568}$ Origins of Christianity, 118

${ }^{569}$, Origins of Christianity, 119
} 
Paradoxically, hypocrisy was manifest at the most transparent locus for social cohesion. At the traditional meal, hypocrisy would contravene sincerity. At least, it would have trumped sincerity if the sincerity of radical forgiveness did not out last the power of the hypocrite. Two opposing forces were unknown to the disciples at the meal, the hypocritical assault of the betrayer and the betrayed's gift of anticipatory forgiveness. But, on reflection, the meal expressed, by anticipation, the invincibility of the forgiving relationship of Jesus.

How explicit were his words of forgiveness at that particular meal? That is almost a nonissue. Forgiveness was an ongoing element in the temporal demeanour of his life and death. A comparable consideration is found in the words of Jesus to his mother and the Beloved Disciple in John's gospel: "Woman, behold your son; son, behold your mother." It is not absolutely impossible, but very difficult to imagine Jesus from his place on the cross saying these audible and coherent words to Mary and John. However, they reflect the fact that Mary and John sensed a relationship with each other which derived from their (perhaps entirely silent) attentiveness to Jesus at the cross. The crucial point about the Word made flesh is that at times the flesh speaks more powerfully than words. It is this point that exposes the temporalizing of the sign. The sign communicates a sense of relationship which cannot be contained by words.

Furthermore, it may be said that the last supper, the supper that lasts, temporalizes relationally, through forgiveness. Firstly, forgiveness is relational and its fruitfulness involves the willingness of the forgiven one to be forgiven. Secondly, forgiveness was intrinsic to the meal ministry of Jesus. The meal itself was an explicit expression of forgiveness. For Jesus, the expression of forgiveness at a meal was a norm. The penultimate meal in Matthew's and Mark's Gospels is a meal at which Jesus' attitude of forgiveness to a woman leads to the woman's exultation and his reproach towards his condemning disciples. A stronger and almost certainly eucharistic expression of forgiveness at table is found in the Lord's Prayer. In Matthew and Luke, the prayer has the words, "give us this day our daily bread, and forgive us our trespasses as we forgive those who trespass against us". Jeremias

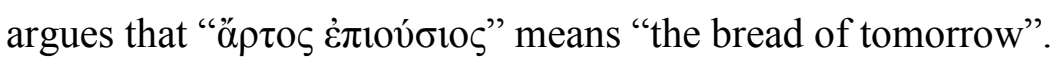

Concerning Jeremias translation, the church father Jerome taught that in the lost Aramaic

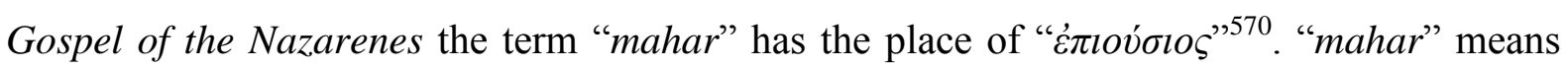

${ }^{570}$ Mt 6:11. 
"tomorrow". Therefore, Jeremias reasons that غ̇ंıov́бıৎ means "for tomorrow"571. O'Loughlin, emphasizes that the word for bread is "loaf" 572 . This would make the daily bread "the loaf of tomorrow", the shared bread of the eschaton.

Jeremias' reading is supported, not only by the unusual word, found nowhere else in ancient Greek literature except the Lord's Prayer. It is also the communal gift of the messianic banquet.

Another closely related point is made through the Didache. In that text the Lord's Prayer leaves out Matthew's and Luke's first forgiveness clause and says: "Give us our daily bread as we also forgive those who trespass against us" ${ }^{, 573}$. This very early, perhaps earliest version of the Our Father, does not require the clause "forgive us our trespasses", presumably because, to ask for "the daily bread" is to ask for the provision of forgiveness. These two clauses in the Our Father of the Didache could be paraphrased, "give us our daily loaf of forgiveness because we also forgive those who trespass against us. "Daily bread [ä $\rho \tau$ s

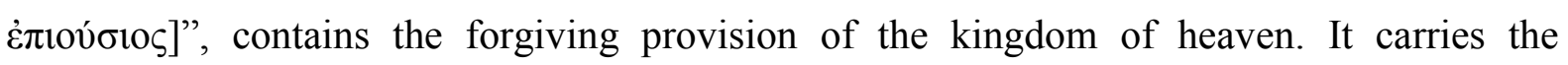
celebration of the eschatological banquet.

\section{Canonization}

Canonization has occurred when a document or a practice has been instituted as an indispensable element in the teachings and practices of a tradition. Canons have an implicit and an explicit sense. A canon has probably not been fully established until it is given explicit documentation. Therefore, canonization is not only produced in documents endorsing the literary legacy of the tradition, but also in documents pertaining to its most important practices. Hence, Eucharistic prayers make reference to canonical Eucharistic practices. Nevertheless, to understand canonization it is necessary to follow the journey from the tacit and implicit expressions of the practice to its official, explicit acknowledgment. The understanding of the Eucharist as the sacrifice of Jesus (the sacrifice of God) was not explicitly acknowledged until Cyprian's letter to Cæcillius ${ }^{574}$. However, implicitly, there has always been a bond between the sacrifice of Jesus and the Eucharist. The fact that a variety of eucharists were celebrated without explicit reference to the death and resurrection of Jesus

\footnotetext{
${ }^{571}$ Jeremias, The Lord's Prayer, 23.

572 O'Loughlin, Didache, 121.

${ }^{573}$ Didache, 8.

${ }^{574}$ Bradshaw and Johnson, 57-58.
} 
does not mean this relationship was lacking, but that it was still in the process of being identified.

A theory on this process of canonization follows. It relates to the discussion in Chapter One concerning the earliest expressions of the Eucharist as a synthesis of oral traditions and Todah meals. According to this theory, a narrative concerning Jesus was recounted and celebrated. The signs of bread and wine formed part of that celebration. This may have been because Jesus practiced it, but more reliably it was a standard practice of celebratory Jewish meals. However, at these traditional meals, the meal practices of Jesus developed increasing prominence.

The number of meal narratives in the Gospels suggests a twofold development in the traditioning of the narratives. Meal narratives increased because they were not only associated with the oral traditioning but also with the celebration of the meal as a sign of relationship and unity. Of these meal narratives, the last supper narrative reached the highest prominence. It became the narrative that most frequently accompanied the meal, and eventually became the sole accompaniment; the other narratives became the narratives preceding the meal. It is also possible that the meal tradition distinguished between lesser meal narratives and the Passover meal narrative. In this way, the general mix of narratives took on their canonical forms in the gospels, while the last supper narratives took on their canonical forms in the celebration of the meal sign.

This does not mean that the canonical meal narratives were maintained according to the letter. The canonization of the scriptures took about 120 years; the canonization of liturgical texts may have been shorter or longer. There is a diversity of canons, including the prayer of Addai and Mari, which does not have an institution narrative, though it is still a last supper mimesis. This suggests that the meal narrative was performed flexibly and according to diverse traditions.

Whatever the merits of this theory, it highlights one point. That, somehow, - and most plausibly, through the process of attaching narratives to the meals, - the eucharistic element of the meal shifted from the beginning of the meal to significantly later in the meal. The earlier part of the last supper in Luke shows that the earliest supper traditions had the liturgical element at the beginning of the meal. This meant the eucharist initially figured as a terminus a quo for the meal, but it became a terminus ad quem. 
Ultimately this transposition would have a significant impact on the relational sense of the liturgical sign. A terminus ad quem, implies accomplishment of the identified purpose of the event. A terminus a quo implies openness to the relationship which does not have such a strongly identified terminus ad quem. William K Gilders shows that the purpose of sacrifice is to share a meal with God. He points out that the temple was furnished in a domestic way. With the altar functioning as a table on which food was burned and that food was to be a "pleasing odour" to the Lord. Therefore, in the liturgical rites, meals and sacrifice were united and a sacrifice is not ordered towards the destruction of life, but to the sharing of life with God and God's people ${ }^{575}$. The gospel meal accounts - from the wedding feast at Cana to the post-resurrection meals - exhibit this sense of life-sharing sacrifice. But if the point of the liturgical rite is openness to God, it makes sense to have the sacrificial element at the beginning of the meal. Therefore, this change would impact on the sense of the meal as a sacrifice.

The importance of this point will become increasingly evident as the thesis continues. Sacrifice generally has the sense of an ending, the offering up unto death. But in the Jewish combination of meal and sacrifice, sacrifice does not imply an unrepeatable ending. Rather, it implies an inexhaustible beginning. To establish the point more, the union of sacrifice and meal does not signify the end or annihilation of one of the parties to the relationship. The provision of a meal signifies the strength to begin anew, thanks to the relationship with the one who makes all things new.

This sense of sacrifice is evident in the sacrifice of Isaac, ${ }^{576}$ with the element of the meal present in the offering of the ram. The Sacrifice of Isaac does not bring Abraham's relationship with Isaac to an unbearable ending, but to a new beginning. Isaac's life has a new horizon, he has been liberated from the Mesopotamian killing of the first-born. Abraham also has a new beginning. He becomes the righteous father of many nations and he walks as a "friend of God.",577

A further point is that the sign, offered at the start of the meal, is not subject to the narrative of the meal. But coming later in the meal, or at its end, it has a more contextualized role in the meal narrative. But leaving the question of liturgical timing aside, once the sense of the

\footnotetext{
${ }^{575}$ William K. Gilders, "Sacrifice in Ancient Israel", https://www.sblsite.org/assets/pdfs/TBv2i5_Gilders2.pdf, accessed March 2015.

576 Gen 22:1-14

${ }^{577}$ Is $41: 8$.
} 
Eucharist as a beginning is allowed to figure, the sense of Jesus as the beginning is able to take on more significance. Like the sacrifice of Isaac, but through the grievous testimony of his suffering and death, the resurrection provides the gift and nourishment of a new beginning. In a meal such as the Todah meal, beginning with a grateful proclamation of deliverance over the cup, and with the breaking and sharing of bread, the testimony of suffering and death, becomes a moment in which the revelation of salvation arrives. The sacrificial sense of the meal is the gift of a new beginning.

When these characteristics of the liturgical meal are observed in the table ministry of Jesus, the eucharist no longer appears to be an invention without a tradition. Rather, it emerges that the eucharistic union of food, sacrifice and communion with God and the participants at the meal, are basic to the tradition of the covenant meal. The added element of forgiveness expresses the sense of a liberating new beginning.

The meal ministry of Jesus expressed in the Eucharist, united sacrifice and meal. This was no ad hoc invention by Jesus. It was an expression of his profound insight into the Jewish tradition of liturgical meals. The unity of sacrifice and meal bring a sense of liberation into the heart of covenant relationships.

For this reason, the Eucharist may well be called "the meal of forgiveness". It may also be called "the meal of the covenant" or "the meal of new life" or many other names. But this means one thing pragmatically and another thing cognitively. Pragmatically, in whatever cultural forms the Eucharist was beginning to develop, this relational dynamic of eschatological forgiveness was communicated through the identification of Jesus' forgiving death with his last meal. But, how was that expressed in the meal? And could the meaning of the covenant meal be transported to wherever people were dining in the Name of Jesus? The Gospel had spread well beyond the forum of the Jewish liturgical meal. A long process of inculturation awaited the establishment of the canons of the Eucharist. However, the narrative of forgiveness and the resurrection provided a way of keeping the temporal significance of the eucharist in view. The emphasis on the forgiving meal was consonant with the tradition of Jesus. Its presence in the Lord's Prayer shows that the eschatological-liturgical meal was at the heart of Jesus' ministry.

Essentially, the last supper accounts do not add to the meal theology expressed in the Lord's Prayer. Existentially they transform it. It is this existential transformation that distinguishes 1 Corinthians 11:23-27 from the Didache. The Didache does not give a death related Eucharist. 
Hence the 1 Corinthians account has greater canonical significance than the Didache ${ }^{578}$. It is through death by betrayal that the eschatological victory of forgiveness is revealed. Therefore, it is far from accidental that the tradition is concentrated in the last supper accounts. The meal that preceded his betrayal was necessarily pre-eminent in the expression of his invincible, eschatological forgiveness.

Hence, the chronological structure of the meals, the presence or absence of texts, in a Judaic, Hellenic, Syriac, Tamil or whatever environment, these were not the canonical matters. The eschatological outpouring of the new covenant through the forgiving witness to new life, through of the death and resurrection of Jesus was the crucial element. And this was held to most simply by prioritizing the narrative of the last supper.

How long did it take for the distinctive element of forgiving relationality to receive universal liturgical expression? The process of canonization or establishment of the rite needs to be described in greater depth. However, the point is that the relational significance of the meal provided the axis around which the process of traditioning began to revolve. What were the implications for the future of Christology and for the theology of the Eucharist? Questions about the identity of Jesus and about the identity of the Eucharist are still unfolding to this day. But the history of the Eucharist is not based on answers to questions about identity, it is based on the mysterious immediacy of relationship that disciples of Jesus believed they received at the sacrament.

The identification of the invincible relational elements has a lot to do with the formation of the tradition. This identification was in the names that were given to the explicit elements of the tradition. "Breaking of bread" and "Eucharist" were not intended to comprehend the elements. They simply gave a name to the repeatable process. They gave insight into how the designated elements emerged and were sustained. The also invited the participants to go deeper than the representations afforded by the labels. The relational elements were celebrated, without being named, they were expressed in the resurrection accounts. Relationships and the meal celebrating those relationships survived the time of the death of Jesus.

At its earliest stages, the pragmatic details of the Eucharistic meals were plainly diverse and lacked formalization. It is possible to begin with the simple observation that people gathered for a meal. However, the meal involved aspects of remembrance and celebration which gave

${ }^{578}$ Didache $9-10$. 
it identifiable traditional characteristics. Furthermore, the remembrance concentrated on the crucified person, Jesus. It not only celebrated his memory, it accepted his ongoing, resurrected influence at the meal.

Expressions of the invincible covenant were recognizable in the pragmatic texts, (the Didache, and 1 Corinthians 11:17-34). They concerned the appreciation that the Eucharist belongs to the temporal horizons of the resurrection. There were different traditions in Galilee to those in Jerusalem and beyond.

Through the processes of time certain practices were found to serve the sense of discipleship more than others. They became the sustained practices. They became nominalized, so

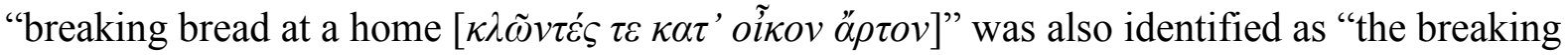

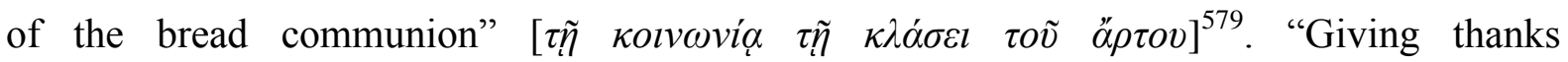

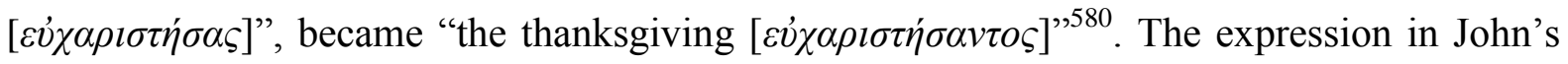

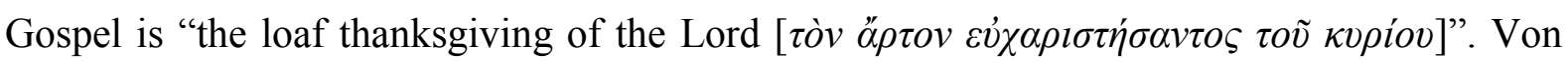
Wahlde strongly suggests that this is a reference to the Eucharist, and the earliest use of the

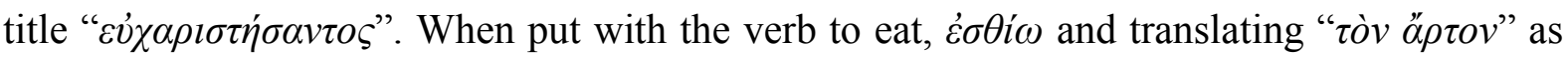
"loaf" 581 the sense of a commemorative title becomes very strong: "they ate the loaf-

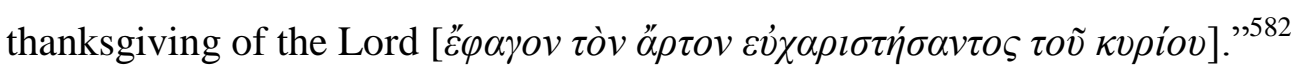

Mimetically remembering and thanking God for and in the death, resurrection and return (maranatha) of Jesus at a meal became increasingly influential as the traditions continued to take shape. Yet, these processes, although they were reminiscent, were incapable of comprehending what was being remembered.

\section{Traditioning}

The meals celebrated during and after the lifetime of Jesus sustained the same emotional gift; the victorious forgiving relationship with Jesus. This gift of relationship had a depth which was not accessible to everyone, but the great apostolic exponents of the Eucharist were able to sustain and communicate it to the other disciples. The sense of these invincible relational horizons therefore found their way into the scriptures. The Synoptics, Paul, the author of

\footnotetext{
${ }^{579}$ Acts 2:42, 46.

580 Von Wahlde, Gospel and Letters, 228.

${ }^{581}$ Cf. O'Loughlin, Didache, 121.

582 Jn 6:23.
} 
Hebrews and the third Editor of John's Gospel all explicitly brought profound relational senses to the Eucharist.

Yet these issues of relationship were incomprehensible. The Eucharist communicated a gift of relationship which proceeded from the father, through the son to the communicant. "As the father lives and I live by the father, so whoever eats me will live by me" $5836: 57$. This was not understandable, but it was believable and, liturgically, it was doable. It was a relational not an intelligible accomplishment. How the identities of the Father, the Son, the communicant or the Eucharist might be defined was extremely obscure. But those identities were intimately communicated through relationship. Nor is there any evidence that the explication of those identities was a priority. Their acceptance may have been a given, but their definition was unthinkable. Admittedly, the I AM statements in the third edition of the fourth Gospel began to expose the problem. But even then, the identities were valued only because of the relationships they gave ("Father I have made your name known to them and will continue to make it known so that the love with which you loved me may be in them and so that I may be in them $\left.{ }^{584,}\right)$.

Were definitions of identity sought? If anything, the emphasis was in the other direction. The incomprehensible sense of relationship could be celebrated in its incomprehensibility and the identities that expressed themselves relationally retained their relational emphasis by avoiding identification; or by only being identified in terms of what they brought to relationship. ("His name is exalted above every other name",585). However, the issue of identity, apart from relationship, arose progressively throughout the following centuries. The identification of the tradition was a major factor in this development, as shown in the previous chapter. ${ }^{586}$ This thesis continues to argue that, since then the metaphysics of identity and then - through the reformation - the intuition of identity, have become increasingly influential in the developments of the Eucharist.

\section{Identity}

This chapter confronts the dominance of identity in the history of the Eucharist. It asks whether the Eucharist is at root a sign of identity or a sign of relationship. It cannot be

\footnotetext{
583 Jn 6:57.

${ }^{584}$ Jn 17:26.

${ }^{585}$ Phil 2:11.

${ }^{586} \mathrm{Cf}$ above, chap. 2, part B, p. sections 1-2.
} 
equally a sign of identity and relationship since "equality" denotes two or more x's that have at least one identifiable element in common, but relationality cannot have an identifiable element. Relationality is other than identity. Therefore, to appreciate the differences between identity and relationship it is necessary to explore both distinctly. Only in this way can the difference be genuinely discerned.

(a) Identity and the Name

At the climax to John's last supper ${ }^{587}$, John provides the prayer (the priestly prayer of Jesus) in which Jesus prays "for those you [the father] have given me". "Protect them in the name you have given me" ${ }^{, 588}$. Van Wahlde argues that the "name" "the father has given" Jesus is "I AM" ${ }^{, 59}$. Van Wahlde's argument is well based in the text. Though, to the contrary, de La Potterie considered "Son" to be the name the Father has given Jesus ${ }^{590}$, but these different understandings are mutually confirming rather than mutually exclusive. The Son who says "the Father and I are one" is necessarily one with the Father in saying "I AM".

At first sight the last supper "I AM" statements and the reference to "the name you have given me"591 are problematic for an argument that prioritizes relationship. Unlike other biblical passages they seem to render issues of identity explicit and crucial. Nevertheless, the priority is relational. "Father I have made your name known to them and will continue to make it known, so that the love with which you have loved me may be in them, and so that I may be in them"592. However, the problem does not stop there. Discussing Exodus 3:14, Thomas Aquinas called the supreme identity God, "the infinite ocean of substances" ${ }^{593}$ addressing the Eucharist, in his famous hymn Adoro Te Devote he sings, "Truth here in hiding, whom I do adore" ${ }^{, 594}$. In what ways does do these words designate identity and in what ways do they designate relationship? This concerns an unacknowledged distinction which has dominated the tradition for almost two millennia. And a considerable obstacle: how can relationality signify in a way that differs from identity when the Name of the identity is the infinite I AM?

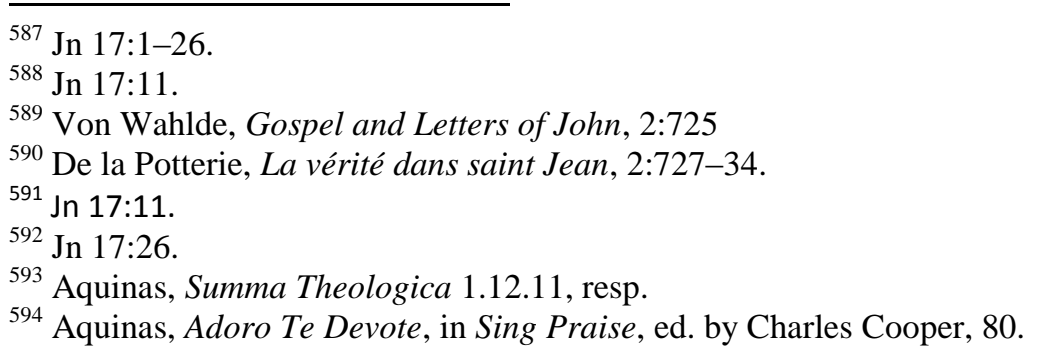


The challenge set for this chapter is to show that "I AM", in John's Gospel, and in Thomas's metaphysics signifies relationally before or beyond its expression of ontological identity. Yet this cannot neglect that the reign of the divine identity who gives the gift of relationship is strongly expressed in the scriptures and Saint Thomas. Marion brings a different sense to that brought by St. Thomas. He treats the eucharist as pure Gift, the Gift is intuitively, not metaphysically given the Gift of faith. ${ }^{595}$ But however it is approached the challenge is evident. If the gift is given first place, does that not mean that the relationality that gives the gift is in some way set aside? Relational traditioning is explored in this thesis in an attempt to address that precise problem.

\section{(b) Relationship}

Relationality is not like identity. It does not appear in the text under the form of proper nouns, nouns and pronouns. It has no identity by which it can be named. Nouns name identities while sentences, combining nouns, verbs and other qualifiers, articulate the performances of relationships. Sentences exhibit relationships that emerge between the figures that form a sentence. The performance of identities and the performance of relationships are expressed by verbs.

When verbs are examined they expose the life of the text; the life that unfolds in time, that temporalizes, among the identities in the text. That life is often a hidden life. This is evident through a second look at the passage quoted above, in which the God identifies Himself as "the God of Abraham, Isaac and Jacob". This is a text which brings together the evident and secret ways of the God of Israel:-

"Say to them, "The Lord God of your fathers, the God of Abraham, of Isaac and of Jacob, 'I

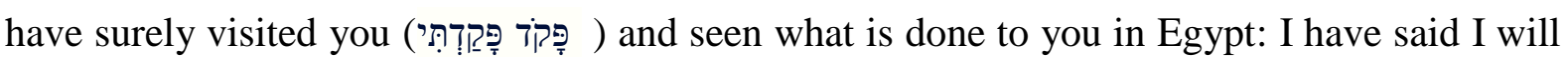
bring you up out of the affliction of Egypt to the land of the Canaanites and the Hittites and the Amorites and the Perrizites and the Hivites and the Jebuzites, to a land flowing with milk and honey",.,"596

\footnotetext{
${ }^{595}$ On Marion's Phenomenology of the Eucharistic Gift in relation tosee the Introduction above, of t , Introduction $\mathrm{B}, 2, \mathrm{~d}, \mathrm{i}$.

${ }^{596}$ Ex 3:16-17.
} 


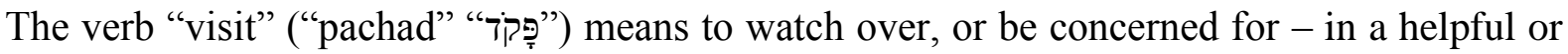
custodial way -. It occurs seven times in the book of Genesis. Six times it directly involves Joseph. It occurs twice in Joseph's prophecy concerning this very moment of liberation.

"I am dying; but God will surely visit you ( פְּקד יפְּקד ), and bring you out of this land to the land of which He swore to Abraham, to Isaac, and to Jacob"597 Then he articulates the depth

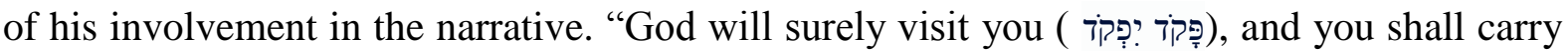
up my bones from here."

Not only is the verb strongly associated with Joseph through the Genesis passages, the verbal

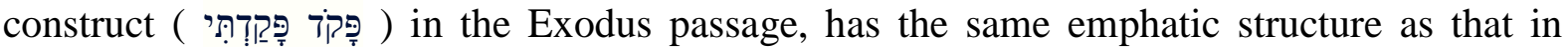

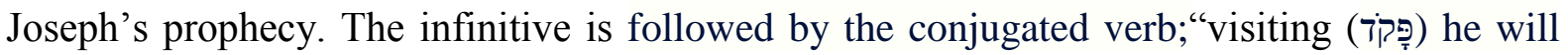

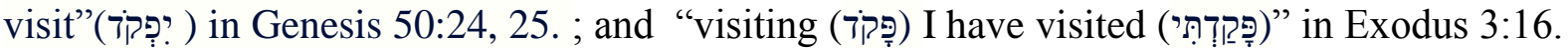
Furthermore, "Joseph" appears on the perimeters of the narrative, in the form of an inclusio. ${ }^{599} 600$. Therefore, Joseph's relationship with the people, and the Lord's relationship with Joseph (and the people through Joseph) figure very strongly in the Exodus text.

The irony is difficult to avoid, if it were not for Joseph, Abraham's legacy through Israel would have become extinct after four generations. Abraham, Isaac, Jacob and their God would have never been heard of. Yet, in the supreme discourse, wherein "the God of Abraham, Isaac and Jacob"-and Joseph-reveals his Name, Joseph seems to reside in oblivion. At least he would be in oblivion if his prophetic wisdom and the relational sign of himself ("you shall carry up my bones from here."601) were not so intimately and inextricably woven into the text. Therefore, the importance of Joseph is not extinguished by the omission of his name. Rather, his name is liberated to signify as a visitor to the text; one who does not dwell in the text through his name, but through his relational gifting.

Joseph does not appear as dramatis persona in the passage which resounds with the indebtedness to him. But the debt is paid. He figures as a kind of secret companion of the one who fulfils his prophecy. God visits according to the word of Joseph. So, Joseph is a witness

\footnotetext{
${ }^{597}$ Gn 50:24.

${ }^{598}$ Gn 50:25.

${ }^{599}$ Ex 1:8, 13:19.

600 "Inclusio" refers to a literary practice of marking of a text, or sections of a text, by repeating an element of that text at the beginning and end of that section. Hence the references to Joseph at the beginning and end of the Escape narrative, mark it off from the remaining narratives that make up the book of Exodus. The fact that Joseph also figures obliquely, at the key moment of the text shows that he is a significant literary figure fir the narrative.

${ }^{601}$ Gn 50:25; cf. Ex 13:19.
} 
to the unrepresentable life of relationship. In this chapter, he figures as a witness that the representational model of the eucharist, which has figured so strongly in its history is profoundly flawed. It suppresses its force as a relational sign.

The above discussion of formative ideas for this chapter, appeals to the encryption of Joseph's testimony in Exodus 3:16 as an argument against seeking the Eucharist through representational and nominal literary references. It is necessary to go to the texts and to the Eucharist, seeking the expressions of relationship concealed in the text. This Chapter appeals to the biblical strategies of oblique references and allusions to Joseph, to underscore the necessity for relational appreciations of the Eucharist.

$\mathrm{He}$ is mentioned here because he exposes the problem with which this thesis has to grapple. If the Bible were read as a book which only speaks plainly, and never obliquely about Joseph, Joseph's voice would be heard very faintly. Similarly, the Eucharist is misunderstood when it is explored only on the basis of representational arguments. Yet the history of the Eucharist is heavy with nominal and representational understandings. In the remainder of this chapter, eucharistic texts will be identified but with a view to discovering the relationality in those texts. This will also be carried out in the analyses of the first and twenty first century texts. It is a matter that will be applied particularly to the Eucharistic theology of Thomas Aquinas.

\section{Part B: How the Eucharist has Temporalized through History}

\section{The Earliest Kinds of Literature Referring to the Eucharist.}

Paul's use of "paradidomi" sustains an emphasis on the concrete sense of the sign rather than on abstractions resulting from it. This Chapter continues the effort to describe the Eucharist on the basis of the concrete temporality of the sign. An important matter to be resolved in relation to the sign is that the meaning of the eucharist arises through the sign, not through a theology that is imposed on the sign. The historical act of traditioning that Paul openly performs through 1 Corinthians 11:23-26, offers a way of exploring the distinct temporality of the sign as well as the linguistic history of its conceptualized attributes. The biblical expressions "my body", "my blood" are allowed to signify without explanation. This means they figure as signs beyond the narrative. The Didache, is another text introducing elements from about the same era as 1 Corinthians. It gives substantial information on the temporality 
of the sign. However, before examining either of these texts it makes sense to examine the most basic material feature of the Eucharist, that of eating and drinking.

Eating and drinking, are intrinsically temporal. To eat is to produce a future, to not eat is to lose the future. However, eating and drinking are also relationally temporal. The life of being nourished begins in the womb. This renders it relational. Therefore, eating and drinking bear witness to the incarnate temporality of relationship. Its involvement in the temporality of relationship means that eating and drinking can be given meanings that are based more in the temporality and symbolism of relationship than in the material existence of food and drink. The narrative and symbolic possibilities that surround food, mean that narratives can begin to govern its significance. But there is a value at the base of the sign which cannot be expressed in the form of a narrative. Narratives themselves have a value, they are also a kind of sign. They not only tell a story, they also signify a relationship between the author or with the narrator of the text and the audience. Therefore, to some extent a narrative is a sign of traditioningBut signs express values that cannot always be expressed in the form of a narrative.

Paul Ricoeur's work, "Soi-même comme un autre"602, proceeds from the linguistics of description to the linguistics of narration and from the linguistics of narration to the linguistics of prescription ${ }^{603}$. Prescription involves expressions of subjectivity that cannot be put into narrative sequences, or even into concepts. Paul the apostle shows his awareness of these kinds of subjective expression when he refers to "sighs too deep for words." ${ }^{604}$ Sighs refer to expressions of mood or value. They may be included in a narrative, but they do not tell a narrative. On the other hand, they may elicit a response. In that sense, they can be communicative signs. The distinction between narrative and sign influences his treatment of the Eucharist.

\footnotetext{
${ }^{602}$ Paul Ricoeur, Soi-même comme un autre.

${ }^{603}$ Ricouer presents and defends "le rythme ternaire: décrire, raconter, précrire." which organizes this great work. "Soi-même comme un autre", 37.

${ }^{604}$ Rom 8:26.
} 


\section{The Precursors to the Eucharist}

(a) Sign and Narrative

A helpful place to examine the difference between sign and narrative is in the relationship between the sign gift of traditioning recounted by Paul in 1 Cor 11:23-26 and the narrative gift of traditioning that he recounts in 1 Cor 15:3.

The relevance of this topic to contemporary ecclesiology may be briefly indicated by comparing Paul's treatment of traditioning in 1 Cor 11:23 with his treatment in 1 Cor 15:3. The former concerns the traditioning of the sign, the latter concerns the traditioning of the Gospel narrative, (the narrative of the death and resurrection of Jesus). The latter affirms the practice of evangelically-based Churches. The former affirms that of eucharistically-based Churches. But what is the relationship between Eucharistic and Narrative traditioning? Paul presented both so he obviously held that it is not a matter of choosing between the two. Therefore, to discover the full sense of his teaching it is a matter of discovering what each kind of traditioning has to offer to the overall tradition. However, a thorough treatment of both kinds of traditioning is beyond the scope of this thesis as it is concerned with the contribution that the Eucharist makes to the tradition and narrative of Salvation. Therefore, because the narrative is well known and because the sign demands a distinction between identifying and relational signification, the focus of the thesis is on the sign. Furthermore, it is not difficult to articulate what narrative has to offer; it offers the confessional gift of salvation.

But precisely what the sign has to offer, is not well known. Because it arises in the familiar environment of the narrative, it tends to be understood in terms of the narrative rather than according to its unique significance. But why would there be a eucharist at all if it were simply another kind of narrative? In the first place, - of itself - it does not tell a story. What distinguishes the sign from the narrative, and what does the sign of the Eucharist bring to the narrative of salvation?

In addressing this topic, Augustine's definition of a sign remains helpful ${ }^{605}$ - "it brings to mind something the sign itself is not". However, a narrative does the same, with one difference. A narrative involves a temporal abstraction. It has a past, present and future time frame, generated in the time of the narrator. A sign does not have a time frame. It is bound to

${ }^{605}$ Cf above, chap. 1, introduction, section 1. 
the time of the event to which it relates, that which is other than the sign. Something of this is evident in a treatment Heidegger gives to narrative in "Being and Time". Quoting Plato, in "Being and Time", Heidegger wrote that the meaning of 'Being' is not disclosed by "telling a story" ${ }^{\prime 606}$. This does not mean the story element in signs is not helpful in the pursuit of the meaning of a sign. It simply means there is an element in signs which is not revealed in a narrative. That element was pursued throughout "Being and Time". It is the incomprehensible temporality of meaning; "the meaning of "Being"". It certainly involved a narrative element; the forward-running sense of Dasein, "being towards death"607. But this forward running element, - so easily diverted to narrative histories - through the dread of mortality - turns towards "care". ${ }^{608}$ The call, through death to care is not itself a narrative. It is a call that may be given many expressions, including narrative, but none of these can be comprehensive. This incomprehensibility itself divulges the way to Being's most profound expression of meaning. Therefore, narrative and sign operate in different horizons of the sense of meaning. The one (narrative) sustains an attachment to meaning; the other (the pure sign) reveals that the attachment to meaning goes beyond the powers of historical intelligibility. At the basis of this thesis is the sense that the sign value of the Eucharist consists in this pre- and nonnarrative call.

The relationship between narrative and call indicates what this chapter asks about and seeks to articulate. How does a narrative, which performs a temporal process of expression, connect with the value or values that motivate that expression? The suggestion is that it arises through signification. The difference between mysterious signification and identifying narrative is displayed in the two texts from First Corinthians where Paul talks about traditioning. The fact that both texts talk about traditioning suggests that they both belong in the traditioned life that Paul was trying to inculcate in the disciples at Corinth.

(b) Temporalization and the Sign

The sign expresses a different kind of temporality to the narrative

The traditioning of the sign occurs in 1 Corinthians 11:23-26. There Paul exhorts the disciples to conform to the tradition that he had received "from the Lord". Among other

\footnotetext{
${ }^{606}$ Heidegger, Being and Time, 5.

${ }^{607}$ Heidegger, Sein und Zeit, 250.

608 "Das Sterben gründet hinsichtlich seiner ontologisch Möglichkeit in der Sorge”. Sein und Zeit, 252
} 
exhortations he conveys the already traditional words of Jesus, "Do this in the remembrance of me".

The traditioning of the narrative is given in 1 Corinthians 15:1-6. There Paul recounts the tradition of disciples to which he belongs, and with whom he has learned to share the Gospel. That tradition goes back to Jesus. It has a different kind of temporality to the Eucharist. The

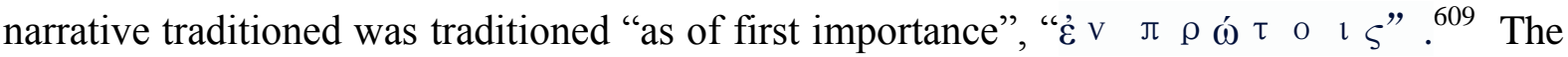
Eucharistic tradition was traditioned "from the Lord" 610 .

Both texts demonstrate the work of traditioning; carrying the sense of the past into the future. But the narrative refers to the origins of its traditioning in the past. The sign, on the other hand, not only refers, it also places Paul to the source of the traditioning, "the Lord". Its purpose is to sustain the bond with the Lord, as it was given in the past, on the night he was betrayed; and to sustain this past bond throughout the present and future generations. The dynamic is strange. It sustains the future-oriented moment that was declared in the past. This is a particular unfolding of the sense of temporalization that is performed with some clarity through the Pauline Eucharist. There is even something of a narrative in his treatment of the sign. The temporalization does tell something of a story. It tells that Paul received the call to tradition the Eucharist and how the appeal to "the remembrance" came about through Jesus. But it does not explain how remembrance signifies.

The significance of a value is not something that can be told; it cannot be narrated. A value must be encountered and lived. It is not only a value but a valuing and if it involves relational valuing, it demands sharing. Sharing is given by the sign. The relational sense of the sign, and of valuing, is intrinsic to Paul's Eucharist. 1 Corinthians 11:27 says "Whoever eats the bread or drinks the cup of the Lord in an unworthy manner will be guilty of sinning against the body and blood of the Lord". This declares the Eucharistic sign to be a share in Christ's valuing of the community, and especially the community of the poor. But it is not only a share in Jesus acts of valuing. The sign expresses the value of Christ himself, his body and blood. His infinite and unconditional worth, the worth of his blood, now offered for disciples. ${ }^{611}$ The narrative of the last supper, provides the sense that this value is sustainable in history but the sign is the value itself The sense of the sign is one with the sense of the last supper, it concerns the communication of a sense of relationship, which is not bound to the

\footnotetext{
609 1 Cor 15:3

6101 Cor $11: 23$

1 Cor 11:27
} 
time of the narrative. The traditioning of both the Gospel narrative and Gospel sign concerns the historical communication of a relationship, which means a relationship value.

(c) On the Temporality and Sociality of Eating

Eating and drinking have a predilective structure. A person does not eat because they do not want an enjoyable future but because they do want an enjoyable future. This is the predilective structure of eating. Food itself signifies time and relationship. Food signifies the future because it gives strength and life. Secondly, it signifies the present. The meal heralds the gift of relationship between the nurturer and the nurtured. The eschatological meal is bound to be everlasting, not only because it occurs at the end of time but also because the end of time is the time of forgiveness.

These matters can be appreciated better by reflecting on fasting. Fasting articulates the fact that the life an individual or community sustains by eating, is itself a relational gift. This is not only biblical; it is an existential universal, from the embryo in a mother's womb to the geriatric who cannot feed him or herself, nourishment involves a profound sense of communication. Biblical fasting expresses that sense of relationship in a religious practice. The sense of relationship involved in eating concerns, among other relationships, the sense of relationship with God. Therefore, fasting is a form of prayer which distinguishes the relational and physical components in the life of a being that eats.

In the canonical Gospels, the first reference to eating in the ministry of Jesus occurs during his fast in the wilderness. The last occurs at the last supper. The spiritual sense of this renunciation is strengthened by the devil's temptation when "he was hungry." 612 "If you are the Son of God, turn these stones into bread." ${ }^{\prime 13}$ At the last supper Jesus says, "Take this all of you and eat it. This is my body". ${ }^{614}$ When Jesus was fasting in the wilderness, the first temptation with which Satan assailed him was to turn "the stones into bread"615. But Jesus was overcoming the anti-relational heart of stone, which prefers material sustenance to relational communication. Hence Jesus responded by prioritizing communication. "Humanity does not live by bread alone, but by every word that comes from the mouth of God". In the

\footnotetext{
${ }^{612} \mathrm{Mt} 4: 2$.

${ }^{613} \mathrm{Mt} 4: 3$.

${ }^{614}$ Mt 26:26.

${ }^{615}$ Mt 4:3.
} 
response to Satan in the wilderness, Jesus declares his desire to live in the power of God's speech. Jesus' fast is revealed as a prayer for relationship.

In this paradigm, only the extreme is apt and an extreme expression of the gift is given by the widow of Zarephath who sustains Elijah ${ }^{616}$. The Lord has instructed her to feed Elijah ${ }^{617}$. She only has enough food for her and her son to eat one last meal before they $\operatorname{die}^{618}$. She tells Elijah this because he has asked for food. He tells her not to be afraid, to go ahead and prepare their last meal, but to give him some food first. "For this is what the LORD, the God of Israel, says: There will always be flour and olive oil left in your containers until the time when the LORD sends rain and the crops grow again!" ${ }^{619}$ The woman does as Elijah says and she does not go without from that time onwards ${ }^{620}$. She has lived by the word of God to the point that there was nothing but relationship and the food that expressed relationship. Similarly, Elijah lives in the relational gift of God's word. Some years after this Elijah also raises her son from the dead ${ }^{621}$.

There is a phenomenological point here. Because the self lives by eating food, the life of the self is sustained by relationships outside the self. The story of the widow of Zarephath is extremely graphic but it expresses clearly the basis of life outside the self, in relationship. Life can only happen through the relationality of the other. Similarly, the prophet Elijah, who may appear selfish, is also living by the power of the word that gives relationship. The life of one who eats temporalizes relationally. Elijah has come testifying to that relationality

This paradigm is very problematic. The relationality outside the self seems groundless. The fast accepts the groundlessness of life and prays that what seems to be groundless may become relational. It may or may not remain groundless, but the prayer is that it becomes relational.

In this articulation of the relationality of eating, the fast of Jesus has a corollary. It testifies to a desire to be spoken into being, to live by the nourishment of God's word. Similarly, the covenant meal, shows that his prayer has been heard. The relational life that has been prayed for by fasting has become provided through the food of the covenant meal. The one who eats the covenant meal, gives herself or himself, to become relationally, through the food of the

\footnotetext{
${ }^{616}$ The account is in $1 \mathrm{Kgs} 17: 8-16$

${ }^{617} 1 \mathrm{Kgs} \mathrm{17:9}$

${ }^{618} 1 \mathrm{Kgs}$ 17:12

${ }^{619} 1 \mathrm{Kgs}$ 17:14

${ }^{620} 1 \mathrm{Kgs} 17: 15-16$

${ }^{621} 1 \mathrm{Kgs}$ 17:24
} 
life-giving relationships that is symbolized in the meal. The depth to which one becomes the food of relationship for the others is related to the depth of his or her fast. The depth of the fast is not decided by the lack of food, but the desire to live for the relational gift of a life that arises outside the self, for the others. The temporality of eating involves the acceptance of life, from outside the self, in the hope of living a life that is formed by the relationality of the infinite. The Eucharist presupposes that Jesus is like Elijah, that he carries the gift of life giving relationship, the gift of exteriority through which life flows.

Similarly, just as the desire for relationship is displayed by the fast of Jesus. So, the gift of relationship is also communicated through the meals of Jesus. Jesus gives the bread of forgiveness. The one to whom he gives the bread may be against him, but he gives it in order to live by the power of the life or relationship, a gift for the other, produced outside him

The themes of movement from indigence to abundance reach a new depth through the death of Jesus - a death which is also oriented towards the messianic banquet which will be celebrated at the end of time. The meal practices of Jesus, risen from the dead, reveal this same movement from privation to abundance.

The pattern is further clarified when the priority of relationship is expressed in other biblical accounts of the relational aspect of meals. Here, when relationship is put first, in times of indigence, a dynamic movement emerges, from isolation and hunger, to companionship and nourishment. This end, can be seen as part of a greater rhythm that flows between indigence and abundance, through the prioritising of relationship. The typological progression from indigence and trial to the abundance of a celebratory meal belongs to a deeper and more comprehensive logic. This logic is expressed in the Jewish liturgical meals that Jesus would have celebrated. Among these the Passover and Todah meals emphasize the journey from desolation to consolation.

Through "prayer and fasting", the relational horizons of material existence assert their authority over those material horizons that can be engaged in without relationship, or through materialistic and exclusive relationships. Fasting is an expression of covenant relationship and often a form of repentance for living without regard for that relationship. When the differences between the relational and material elements are expressed through fasting, God is invoked for the restoration of food and material existence to its proper place in life. It is no longer idolised. But more importantly God is invoked to nourish the life of relationship. 
(d) The Predilective and Anamnetic Senses of the Sign

The relational sense of food causes it to function as a sign as well a substance. The sign not only indicates (albeit vaguely) a desired meaning; it also indicates that desiring expresses a meaning that goes beyond the historical presence of the sign. When Jesus speaks of the Passover meal, his desire has an apocalyptic term - "with desire I have desired to eat this Passover with you before I suffer; for I will not eat it again until it is fulfilled in the kingdom

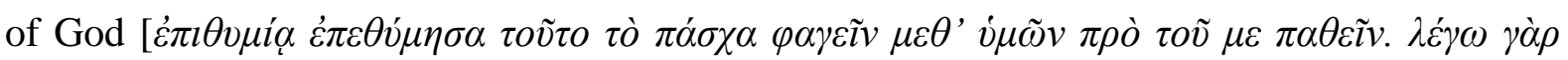

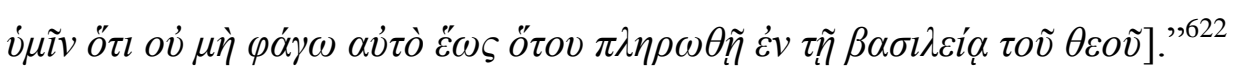

The Passover meal motivates a desire that arises from outside the narrative. It is a sign which surpasses history. The expression or revelation of a desire does not narrate the outcome of that desire. It simply communicates the fact of the desire and the sense of worth that is voiced by the desire. Admittedly, through this desire there is a motivation to narrate its outcomes. This motivation is in the predilective structure of the desire. But predilection itself, the meaning of desire, is not a narrative, nor is it an event. It is a value that finds expression in the temporality of the sign. This chapter now focuses on the gift of the eucharistic sign, namely, its temporalization through predilection and anamnesis.

Predilection means, loving the other before the self. It is the condition of a being that breaths and eats. Before it relates to the outside air and food, it is already living from the air and the food. Bodiliness cannot live for itself alone because it cannot live alone. The self has already been living relationally before it has come to recognize itself. Therefore, before it has been living in the time of its own presence, it has been living in the time of another, outside it. Predilection is the willingness to live in the time of the other.

The time of the other is encountered through predilection and remembrance The words of Jesus at the Eucharist, "Do this in memory of me", may be understood to refer to the time of the other. Jesus who has died and risen lives in a unique kind of time. The sacrament emerges as an invitation to live in the time of Jesus. This is the predilective time of relationship.

A clear biblical expression of predilection is found in a prophecy that Jeremiah gave concerning Ephraim. "Though I have spoken intensely against Ephrem I still earnestly remember him. I will have mercy on him abundantly" ${ }^{623}$. The sense of the text is clear. Ephrem has offended God but God cannot help loving him. God's relationship with Ephraim

\footnotetext{
${ }^{622} \mathrm{Lk} 22: 15-16$.

${ }^{623}$ Jer 31:20.
} 
is not determined by Ephraim's behaviour towards God; he "remembers" Ephraim with a passionate and devoted attitude of "mercy". God will "put mercy on him" like an anointing or like clothing. This is the beautifying favour of predilective love. Time cannot wear it out. Time and distance only elicit its evermore creative remembrance. The words "do this in the remembrance of me" express a desire to be in a time of relationship outside the time of the self. These points will be considered further in Part D of this chapter.

\section{Temporality and Relationship in Early Texts}

The earliest tradition of the Eucharistic prayer, the Aramaic tradition, has no words spoken over the bread and wine ${ }^{624}$. The absence of an institution narrative clearly witnesses to a significance in the signs, prior to discourse. Therefore, a theory about table discourse does not address the basic issue that the primitive significance of eucharistic signs is probably not the result of their having words attached to them. It may well be the other way around. The words are attached because in their original Aramaic context, the signs had a significance to which the Greek speaking communities were insensitive. Therefore, they needed to introduce words.

Signs do not only serve a pre-existing narrative. Nor do they only refer. Meanings arise through the sign and in some instances, these signs are not referential at all. When it is free from predetermining narratives and understandings, the sign communicates. It communicates the sense of time and the gift of relationship. It gives rise to senses that only exist through the sign itself. Attempts to account for the invention of the sign on the basis of a narrative are fraught because the narrative imposes an orientation on the sign. The sign, thereby loses its power to communicate and becomes shaped by the narrative, no longer signifying in its own terms. However, when the narrative connects to the sign without defining it, the sign communicates and forms the bond of relationship.

How does the eucharist signify holiness? Holiness concerns the way the eucharist signifies of itself. This is what is traditionally meant by the radical uniqueness, or holiness, of eucharistic signification. The argument put forward in this thesis is that the holiness of the eucharist signifies, unconditionally, according to its own sense, in history. If this is not the case, there is no such phenomenon as the eucharist; there is only the pretence of a eucharist. But the

${ }^{624}$ Bradshaw and Johnson, The Eucharistic Liturgies, 39. 
sense of the sign is not a sense for itself. Its holiness is its radical givenness to the sense of the other.

\section{(a) The Didache}

The ancient text of the Didache is invoked in this discussion because it provides an illuminating emphasis on gratitude. In the following reflection, the text is introduced and

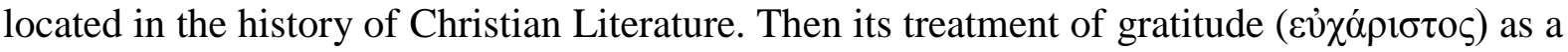
temporalizing relationship with God, is briefly described.

The Didache teaches the way of the apostles, a "way of life" and not of "death" 625 . It reads largely as wisdom literature. It has ethical admonitions similar to those attributed to Jesus in the Gospels. It also speaks of "the Lord" and "God" in a way that strongly suggests that Jesus is being referred to. It does not refer to the death or resurrection of Jesus. Without a theology of baptism, it calls for baptism "with living water", "in the Name of the Father and of the Son and of the Holy Spirit" ${ }^{\prime 626}$. Between the very brief paragraph on baptism (7) and the short paragraphs on the eucharist (9 and 10) it stresses the avoidance of hypocrites and hypocrisy and gives the Lord's Prayer as the model of faithful prayer ${ }^{627}$. Its version of the Lord's Prayer is almost a replica of Matthew's version. To the extent that it differs from Matthew's version, it is shorter and simpler. The Didache has "give us our daily bread because we forgive our

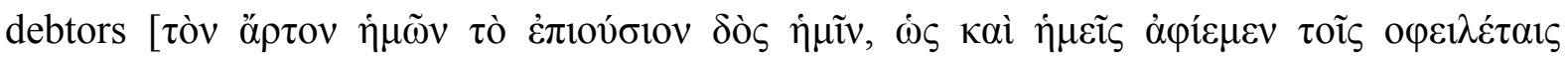
$\dot{\eta} \mu \tilde{\omega} v]$ "628 where Matthew has "give us this day our daily bread and forgive us our trespasses

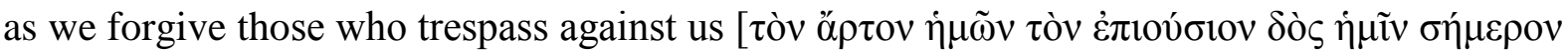

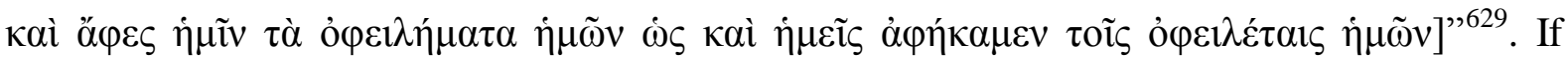
anything, the simpler and shorter expressions favour the Didache having an earlier version than Matthew. The causal link through "as [i் $\kappa \alpha i]$ " from "give us our daily bread" to "we forgive those who are indebted to us" ("give us our daily bread because we forgive those who are indebted to us") suggests a primitive and classical biblical link between forgiveness and table fellowship. This was one of the hallmarks of the table fellowship of Jesus, as was the

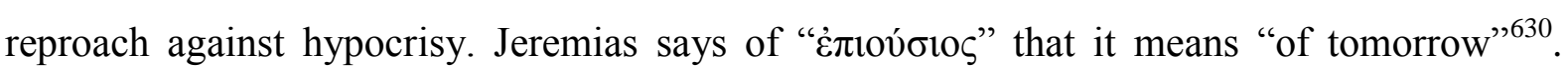

\footnotetext{
${ }^{625}$ Didache, 1.

${ }^{626}$ Didache, 7.

${ }^{627}$ Didache, 8.

${ }^{628}$ Didache 8.

${ }^{629}$ Mt 6:11-12.

${ }^{630}$ Jeremias, The Lord's Prayer, 23.
} 
That it is the eschatological meal. This means that the bread comes into this age as a gift of forgiveness from the age to come.

It also suggests that the next two paragraphs on the eucharist, although they are uncharacteristically theological and almost certainly contain added liturgical material, have a carefully designed place in the first edition of the text. The central paragraphs - 7, 8, 9, 10 are structured to lead from baptism (7) to prayerful table fellowship (9 \& 10) through the Lord's Prayer (8). The two paragraphs on the eucharist also have a progressive dynamic. They start with thanksgiving over the cup and bread (9). They conclude with thanksgiving "after you are filled" (10). The difference between the prayers before and after the reception of the sign is striking. The prayers before express gratitude for God's provision of food and drink through his child Jesus. However, the prayers after not only express gratitude for God's kindness but also gratitude for the in-dwelling name of God and Jesus. This in-dwelling is the result of the food and drink having been received. Therefore, there is a time of anticipatory gratitude and a time of fulfilled gratitude in the process of the liturgy.

The strategic placement of the Lord's Prayer and the distinction between prayers before (9) and after (10) the reception of the liturgical signs, shows that, from its earliest moments it served as a guide to liturgical practices. The likelihood of added materials has no impact on the fact that the original composition, which gives the plan of the work, was a very early document. The obvious bonds with an early tradition of Jesus and the lack of theologically developed material commend the text as a clear guide to the earliest practices.

Reflecting further on the main eucharistic passages ( $9 \& 10)$, these provide further evidence of its being a primitive text. The Didache places the prayer over the cup before the prayer over the bread. This order for the eucharist is only found in the most primitive scriptural fragment on the "last supper"631. However, it is also the order at the Jewish Sabbath and Todah meals. The eucharistic passages of the Didache also refer to Jesus as the "child" or

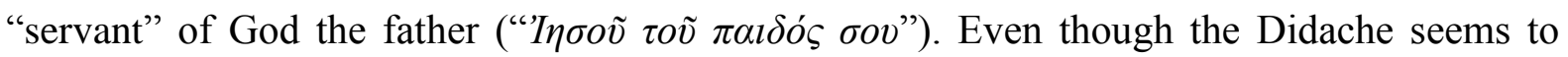
display a fairly high eucharistic Christology the use of $\pi \alpha l \delta o ́ \varsigma$ seems to be somewhat low. It does not occur in any other primitive texts and it does not emerge in developed texts. This suggests, very strongly, that it was a primitive title that fell out of use. It may have meant "servant". However, it probably emphasizes a familial sense of intimacy at the domestic table and means "child". Perhaps its ambiguity counted against its continued use but, be that as it

${ }^{631}$ Lk 22:18-19a. 
may, the text emphasizes the intimacy of the divine father with the communicant through Jesus. Therefore it emphasizes loveableness.

A final point is that, compared to the rest of the Didache, the prayers for the eucharist are long and theologically developed. Like the New Testament texts (with the exception of John 6) it is short. However, in terms of the Didache, it is five times the length of the very pragmatic section on baptism. This strongly suggests that it has been introduced after the initial composition of the document. This does not make it alien material. The unique title, " $\tau o \tilde{v} \pi \alpha l \delta o ́ \varsigma \sigma o v "$, suggests that the eucharistic prayers are early. But, the distinctive writing style suggests that they originate from outside the text. It is probably a reasonable assumption that the title, along with other elements ${ }^{632}$ belonged to the oral history of the "eucharist" documented in the Didache. There is no reason to assume that the documentation was verbatim, but it would have been faithful to the tradition. Clearly this tradition sustained a profound theological formation and it was characterized by an exuberant emphasis on the gift of thanksgiving. It is this emotional element that may be encouraged but cannot be defined by metaphysics. To sustain this element, the Didache and the primitive Church celebrated the eucharist.

The Didache concludes by admonishing "vigilance" in preparation for the end of the world $^{633}$. "Watch for your life's sake". It also teaches about the coming of "the worlddeceiver" who "will appear as the Son of God" and declares "that those who endure in faith will be saved from under the curse itself." These eschatological elements contribute something more than a metaphysic but they do not demonstrate the communication of relationship that the New Testament espouses through its proclamations of Jesus. In fact, the Didache only mentions "Jesus" explicitly in the texts on the Eucharist. The Didache apocalyptic differs from New Testament eucharistic apocalyptic. Neither does it refer to the return of Jesus, nor link the eucharist to the end of the world.

However, the Didache exhibits significant expressions of temporality during the liturgy (by distinguishing the anticipatory and fulfilled thanksgiving). Anticipating the consumption of the Eucharistic meal, paragraph 9 prescribes an anticipatory thanksgiving. "We give thanks to you, our Father, for the Holy Vine of David your child, which, you made known to us

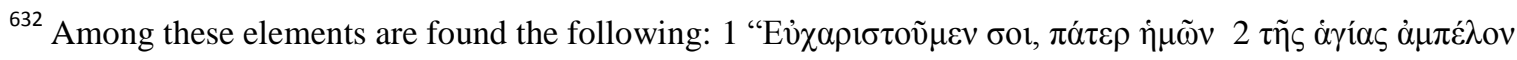

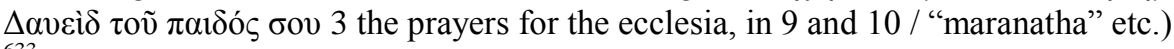

${ }^{633}$ Didache, 16.
} 
through Jesus your Child; to you be glory for ever." ${ }^{634}$. After having consumed meal paragraph 10 prescribes a fulfilled thanksgiving. "We give thanks to you, O Holy Father, for your Holy Name which you made to tabernacle in our hearts". This expresses the gratitude of fulfilment. The difference between the anticipatory and the fulfilled reveals the progression from the liturgical food being physically outside them (9), to gratitude for the food being physically within them (10). This exhibits the agreed steps of the early liturgy. It celebrates the expectation of the kingdom and further celebrates its arrival. Hence, according to the Didache, the temporality of the Eucharist conforms perfectly with the fact of eating. On the other hand, it does not develop other aspects of eucharistic temporality, especially the connections between eating, drinking and sacrifice. Because it does not link the consumption of the bread and wine to the sacrifice of Jesus it limits the sense of relational temporality that the Eucharist offers.

(b)The Eucharist in Luke - Acts

(i) The Two Meal Traditions in Luke

Again, relational temporality can be seen in the earliest manuscript of Luke's Gospel. Given contemporary understandings of the primitive eucharists, verses 22:17-19a can be read as a very early model of a Eucharist, i.e. it describes the moment of prayer with the cup and then the breaking of the bread which began meals. Then a later redactor wrote of a Eucharist that was more clearly distinguished from the meal. The meal is connected to the apocalyptic saying over the cup. This saying, also in Matthew and Mark indicates an apocalyptic environing of the meal which, like the first part of the meal in Luke, ${ }^{635}$ predates the words of institution. The meal temporalizes as an apocalyptic sign. It is not possible to eat without the eating indicating a moment of vitality beyond the moment of eating. These indicators of a meal practice that predated the more formalized Eucharist of Luke (22:15-16 and 22:19b-24) invite reflection on the regular liturgical table ministry of Jesus.

\footnotetext{
${ }^{634}$ Anticipating the consumption of the Eucharistic meal, paragraph 9 is an anticipatory thanksgiving. "We give thanks to you, our Father, for the Holy Vine of David your child, which, thou made known to us through Jesus thy Child; to thee be glory for ever." Didache 9.

111 Reflecting on the consumed meal paragraph 10 says, "We give thanks to thee, O Holy Father, for your Holy Name which you made to tabernacle in our hearts".

${ }^{635}$ Lk. 22:17-19a.
} 
(ii) The Language of Food in Luke

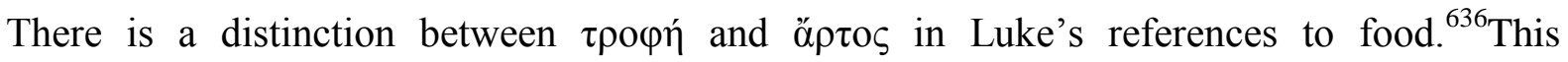
distinction is reflected in 1 Corinthians, 11: 17-34. There Paul uses $\tau \rho \circ \varphi \eta$ to refer to the

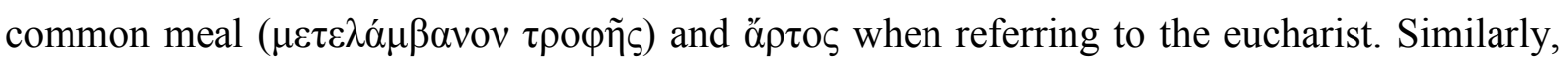

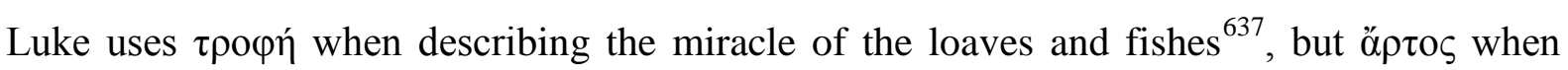
referring to the Last Supper ${ }^{638}$ and the meal at Emmaus. ${ }^{639}$

(iii) The New Communicative Life of the Eucharist

It is evident that scripture refers to the same liturgical meal by both "the breaking of the bread" (Lk 24:35; Acts 2:42) ("he -" "they broke bread" Lk 22:19; 24:30; Acts 2:46) and "the supper of the Lord" (1 Cor 11:20). Luke and Paul both invoke the contents of the last supper narrative through these expressions. In doing so they also demonstrate a distinction between the liturgical meal (or the liturgical moment of the meal) and the community meal. When writing to the disciples at Corinth, Paul admonishes them for their lack of a community ethic at the community meal. "Those who have eat first" (1 Corinthians 11:21); those who have not, go without. This break between a non-liturgical and liturgical environment is also evident in the celebration of the dawn Eucharist in Acts 20:11, both in the environment and in the phrase "when he had broken bread and eaten".

(iv) The Eschatological Element in Paul's Supper of the Lord ${ }^{640}$

"When you meet together, it is not the Lord's supper that you eat. For in eating, each one goes ahead with his own meal"641. This matter which involves "humiliating the poor and disrespecting the ecclesia of God"642 at what is supposed to be "the supper of the Lord" is described in 1 Corinthians 11:17-22. But those verses are a prelude to the exposition of the problem: the unacknowledged "supper of the Lord". It holds a hidden element with which Paul aims to convict the community. To establish the weight of the occasion he introduces a

\footnotetext{
${ }^{636}$ Cf Acts 2:46 and 2:42.

${ }^{637}$ Lk 9:12-7.

${ }^{638}$ Lk 22:14-22

${ }^{639}$ Lk 24:28-31.

${ }^{640} 1$ Cor 11:23-34.

${ }^{641} 1$ Cor 11:20-21a (RSV).

${ }^{642} 1$ Cor 11:22.
} 
traditional account of the supper, which he "received from the Lord" ${ }^{\prime 643}$. Then he articulates the significance of this meal. It is the Lord's eschatological meal. Hence the eschatological horizon - announced in verse 26 - witnesses as the environment in which the meal is eaten and drunk ${ }^{644}$. In this environment Paul renews his admonition. The practice of the Corinthians not only reveals a lack of neighbour love, it also demonstrates a serious ignorance of the eschatological crisis that arrives with the celebration of the supper of the Lord. "Whoever, therefore, eats the bread or drinks the cup of the Lord in an unworthy manner will be guilty of profaning the body and blood of the Lord" 645 . "For anyone who eats

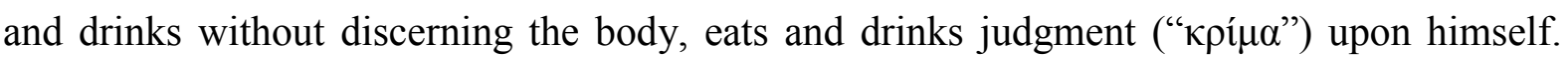
That is why many of you are weak and ill, and some have died." ${ }^{\prime 646}$. Paul concludes this instruction with the words: "when you come together to eat, wait for one another-if anyone

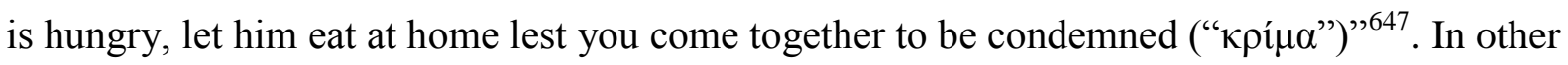
words: unless you are prepared to practice the ethos of the eschatological environment of the "Lord's Supper" don’t come into it.

\section{Part C: Through Metaphysics to Phenomenology}

This section argues that once the identity of the sign is explored fully, it emerges that its roots are relational. The chapter explores the sense of eucharistic identity in Thomas Aquinas. By examining his teaching on eucharistic change and Trinitarian relationships, it becomes evident that eucharistic identity is an identity consecrated by relationship.

This study does not set out to invent a phenomenology of the Eucharist which might simply validate contemporary eucharistic approaches. Rather it aims to find a phenomenology of the Eucharist in the eucharists of the past and of today. A phenomenology of the Eucharist must already be evident, to some degree, in the history of the metaphysical eucharists and its predecessors. If a phenomenology of the Eucharist does not arise from within the history of the Eucharist, it does not express a meaning that comes from within the Eucharist. Such an

\footnotetext{
${ }^{643} 1$ Cor 11:23-26.

${ }^{644} 1$ Cor 11:27-34.

645 1 Cor 11:27.

${ }^{646} 1$ Cor 11:29-30.

${ }^{647} 1$ Cor $11: 33 \mathrm{~b}-34 \mathrm{ab}$.
} 
approach would offer a perspective upon the Eucharist, rather than a phenomenology of the Eucharist.

Finding implicit phenomenologies in previous eras of the Eucharist is an encouraging prospect that motivates this thesis. This part of chapter 3 begins by exploring the metaphysical Eucharist of St Thomas Aquinas. Under the guise of the institutional gift, Thomas' reflections on the Eucharist included sustained reflections on the topic of absolute change. This testifies to a vital sense of temporalization in the history of the Eucharist. It emerges that the temporalization is absolutely relational. If relational temporalization can be found in mediaeval metaphysics, a fortiori, it will be accessible in the eras of the Eucharist that pre-dated the rise of classical and mediaeval Eucharistic metaphysics.

\section{Thomas' Texts on the Eucharist}

This sub-section engages with Thomas' treatment of the Eucharist in the Summa Theologica Part 3, Question 75, Articles 7 \& 8.

\section{(a) The Concealed Depths of Thomas' Texts}

When Thomas Aquinas published his treatment of "transubstantiation", the final three articles for the first plan were (Article 6) 'Whether this change is instantaneous' (Article 7) 'Whether it is more miraculous than all other change' (Article 8) 'By what words may it be suitably expressed' ("Sexto, utrum conversio ista fiat subito. Septimo, utrum sit miraculosior omni alia mutatione. Octavo, quibus verbis convenienter exprimi possit".) ${ }^{648}$ However even though he published this agenda, the actual course he provided did not follow that. $\mathrm{He}$ omitted his prefaced "Article 7: Whether it is more miraculous than all other change" which appears to be the only occasion in the great Summa that Thomas' prefaced and actual agendas differed.

Having omitted the seventh of these articles from the discussion, he placed another question at the beginning, Article 1 - "whether the sacrament is the body of Christ according to truth,

\footnotetext{
${ }^{648}$ Thomas Aquinas, Summa Theologica part 3, question 75, article 8, schema, at S. Thomae Aquino Opera Omnia. Corpus Thomisticum. Compiled by Enrique Alarcón. Pamplona: Universitas Studiorum Navarrensis, 2000-. http://www.corpusthomisticum.org.
} 
figure or sign". This insertion of an additional first article meant that article 6 became article 7. The omission of the proposed article 7 meant that article 8 remained unchanged.

Thomas' answer to Article 1 - "whether the sacrament is the true body of Christ" was - "it is the true body and blood of Christ in this sacrament, which cannot be grasped by the senses, but only by faith, which rests on Divine authority". Doubtless this was a necessary adjustment to the professor of Catholic theology's programme. However, this does not explain why he eliminated Article 7. Clearly, Thomas affirmed that transubstantiation is the most miraculous of all changes. He had spoken elsewhere of "Our Lord's greatest miracle" ${ }^{649}$., In Article 8 he also noted, discreetly, that "this would be more miraculous than creation" 650 . But for some reason he displays an unusual reticence about declaring transubstantiation to be more miraculous than any other change.

Why this reticence? By taking the question out of his original plan and replacing it with another, he prioritized the statement of the dogma. But by withdrawing a question, he also initiated the forum of the via negativa - 'It is the body of Christ, but not as you would naturally think of it'.

\section{(b) Pedagogy in Thomas}

Thomas' treatment of Question 75 is unusual. In reworking the plan without correcting it, he appeared lax and a little incompetent. He not only presented an original article 7 and then withdrew it. He also introduced, un-announced, the most important article (a Dogma), as though he had initially forgotten it. Why should he make this mistake? It happens nowhere but in the presentation of this most valued topic.

Things become clearer in light of a precedent set by Maimonides. ${ }^{651}$ When speaking about God, Maimonides was concerned to protect God's ineffable transcendence ${ }^{652}$. Compared to Maimonides, Thomas was much more loquacious about transcendence but it seems that, when teaching on the Eucharist he could only witness to, rather than speak about, its ineffable depths. Thomas was familiar with Maimonides ${ }^{653}$. So it is most likely that the

649 "miraculórum ab ipso factórum maximum" St. Thomas Aquinas, Corpus Thomisticum Opusculum 57, in festo Corporis Christi, lectio 2.

650 “quia haec conversio videtur esse miraculosior quam creation", Summa Theologica, 3,75,8, arg 3.

${ }^{651}$ Alvin J Reines, "Maimonides True Belief Concerning God: A Systemitization."

${ }^{652}$ Reines, "Maimonides' True Belief", 30.

${ }^{653}$ Frederic Coppleston, Albert the Great to Duns Scotus, 144. 
correspondences with Maimonides are intentional. But, whatever the case, the issues Maimonides raised in speaking about the ineffable, clarify the problematic with which Thomas was working as he taught about the Eucharist.

Firstly, Maimonides taught the need for a teacher to put an advanced point in a "lax" and "incompetent way"654, and then withdraw it. "Leave it so in accord with the listener's imagination that the latter will understand only what he now wants him to understand. Later, in the appropriate place, that obscure matter is stated in exact terms and explained as it truly is

Thomas' practice clearly concurs with Maimonides. By positing and then withdrawing a topic in the initially planned article 7 , Thomas seems to be presenting his course in a lax and incompetent way. However, this is as Maimonides advised. Prior to withdrawing the question, he has set the process up and asked "whether transubstantiation is more miraculous than any other change?"

But, remarkably, Thomas does not take the question up again. This conforms to Maimonides' second practice. It concerns discussion which relates to God's absolute transcendence. This can never be spoken about. However, Maimonides also has advice on how to accommodate the gift of speech when considering the absolutely ineffable. Maimonides approaches this problem through the taciturn acknowledgment of contradictions. ${ }^{656}$ Thomas does the same.

On the way to the encounter with absolutely ineffable transcendence the enquirer encounters contradictions. These are not contradictions to God but they are to the one who is seeking God. According to Maimonides, those who are not able to accept them should not be exposed to them ${ }^{657}$. Those who are able may pick up on them and learn from them. ${ }^{658}$ To avoid an undesirable encounter with contradictions Maimonides' advice is to separate the contradictory premises so that those learning one set of premises are not, at the same time, exposed to its contradictory premises ${ }^{659}$.

This second problematic, the most profound, seems to provide the core reason for Thomas' extremely uncharacteristic foible. A contradiction displays itself in his premises for declaring that transubstantiation is "is more miraculous than any other change" separate those premises. He separates the contradictions by positing and withdrawing Article 7 ("whether transubstantiation is more miraculous than any other change"). In doing so he

\footnotetext{
${ }^{654}$ Reines, 30 .

${ }^{655}$ Reines, 31 ,

${ }^{656}$ Reines, 31

${ }^{657}$ Reines, 31.

${ }^{658}$ Reines, 31.

${ }^{659}$ Reines, 30.

${ }^{660}$ Summa Theologica, 3, 75, 7
} 
suggests a certain independence between the proposed article $6^{661}$ and article 8 . This is a ruse. The fact of the matter is that these two articles are interdependent, but they also contradict each other. However, the actual contradiction is the withdrawn article itself. Therefore the contradiction never gets stated in plain terms.

However, the contradiction is evident when the articles are held together in one reflection. The proposed Article 6 (now Article 7) describes the instantaneous (hence non-temporal) existence of the eternal in and through the consecration of the bread and wine. It considers "whether this change is done (fiat) instantaneously"662 Article 8 describes the temporal process by which bread and wine are changed into the body and blood of Christ. It asks "whether it is write to say, "the body of Christ comes (fit) from bread" 663 .

That he is entirely aware of this contradiction is obvious from the objections he raises to each proposition. To the argument for the instantaneous becoming of the Eucharist he objects, "Ambrose says, that 'this sacrament is confected by the word of Christ'. But the word of Christ is spoken successively. Therefore this change happens successively." ${ }^{\circ 64}$ But then, to the argument for the progressive becoming of the sacrament he objects, "becoming ends at having become something, but it is never true to say, 'bread is the body of Christ', or 'bread has become the body of Christ'. Therefore it is not true to say that Christ comes from bread". 665

Of course the objections fail to defeat the main assertions. On the one hand, the change is instantaneous, like something coming from nothing (Article 7). On the other, the change is progressive, like something coming from something (Article 8). He resolves all things by saying in response, the change is not successive because the absolutely new happens at the instant the priest completes the words of consecration ${ }^{666}$. But the change is progressive in that something that was before the change (the accidents of bread and wine) is carried over into what results from the change. Therefore the change is greater than the creation of the world because not only does being happen instantaneously (as at the beginning of the creation) but

\footnotetext{
${ }^{661}$ In the text of the argument Article 6 becomes Article 7. This is because Thomas instates a new "first article", on the Dogma of transubstantiation itself. Article 8 remains the same because the originally mooted article 7 has been withdrawn.

662 "utrum conversio ista fiat subito" Summa Theologica, 3.75.7.

663 "ex pane fit corpus Christi"

664 "istud sacramentum Christi sermone conficitur. Sed sermo Christi successive profertur. Ergo haec conversio fit successive." " Summa Theologica, 3,75,7, arg 3.

${ }^{665}$ fieri terminatur ad esse, vel ad factum esse. Sed haec nunquam est vera, panis est corpus Christi

${ }^{666}$ Summa Theologica, 3, 75, 7, ad 3.
} 
also what was before, outside and absolutely incommensurate with the instantaneous event is now brought into it as if it belonged with it. ${ }^{667}$

This is the nub of the contradiction; that the infinitely instantaneous and the progressively temporal coincide in the one event which is the Eucharist. Thomas seems to have tamed the Lion. But arriving at these resolutions, or seeming dissolutions, of the contradiction Thomas has left a great deal unsaid. The implications of his insights seem far in excess of his statements, as profound as they are. Nevertheless, he made a decision not to explicitly explore the original Article 7 "whether this is more miraculous than all other change?"

So what becomes of that unexplored question? Today new reflections are possible because phenomenology offers the vocabulary of temporalization to the questions Thomas was considering. That vocabulary was not available to him, yet when his revelation at the Eucharist on the feast of St Nicholas 1273 rendered him speechless ${ }^{668}$, he invited the world to think more deeply about the ways his writings were bound to the ineffable. One possibility is that the initially proposed article 7, about which he never spoke (even omitted from his completed treatment of the Eucharist in the Summa) offers evidence of the insights through which he became exposed to the ineffable.

One unique characteristic of his work was his commitment to the bond between Christ and the accidents of bread and wine. This may involve a commitment to the passive element of the Eucharist, the terminus a quo which is initially bread and wine, and becomes the accidents through which Christ signifies. The active element, paradoxically, is the terminus ad quem, which is Christ the infinite, second person of the Trinity. At first reading the final line of question 75 seems to eliminate the significance of passivity ("for this change is not made through the passive potential of the creature, but only through the active power of the creator." ${ }^{669}$ ). However, the active potential of the creator does not eliminate the passive potential in the accidents of the creature. If the passivity of the creature were not somehow in the accidents, the accidents would not have carried over into the end of the change. Then this would not have been the most miraculous of all changes. Like the other accidents of bread and wine, its passivity must have been converted into becoming accidents of Christ. Therefore the passivity is not eliminated but altered. In what way is the passivity of the

\footnotetext{
${ }^{667}$ Summa Theologica, 3, 75,8,ad 3

${ }^{668}$ Cf Peter A. Kwasniewski, "A Tale of Two Wonderworkers."

669 "non enim haec conversio fit per potentiam passivam creaturae, sed per solam potentiam activam creatoris" Summa Theologica 3,75, 8, ad 4 .
} 
creature altered? What other horizons of passivity were opening to Thomas as he pursued these mysteries? The remainder of this section seeks to discover other expressions of passivity in the late works of Thomas. His passion for the Eucharist, even his passion for the accidents of the Eucharist, seems to hold the key to the distinctive element in his eucharistic faith. His faith was so intensely eucharistic, that it was at the Eucharist that he received the revelation which rendered him silent. "I can no longer write. My words are as straw",670.

\section{God in Himself as Beloved in Lover (Compendium of Theology, 1; 45)}

God in Himself as Beloved in Lover (Compendium of Theology, 1; 45)

As the object known is in the knower, to the extent that it is known, so the beloved must be in the lover as loved.

The lover is in some way moved by the beloved with a certain interior impulse.

Therefore, since a mover is in contact with the object moved, the beloved must be intrinsic to the lover.

But God, just as He understands himself, must likewise love Himself: for good, as it is understood, is loveable to itself

God is in Himself as Beloved in Lover ${ }^{671}$.

(a) Thomas' Legacy, after his Visions

Thomas did write a little more, presumably after the first of the visions recounted above. This chapter of the Compendium, through the words "movetur" and "contingat", shows a still developing vocabulary in his reflections on movement, even when the moved is God. In this thesis, the logic of that expression is being treated as a phenomenological breakthrough -

\footnotetext{
${ }^{670}$ Cf, George T Peck, The Fool of God: Jacopone da Todi, University of Alabama Press, University, Alabama, 1980, 171.

${ }^{671}$ Quod Deus est in se ipso sicut amatum in amante

Sicut autem intellectum est in intelligente inquantum intelligitur, ita et amatum esse debet in amante

inquantum amatur. Movetur enim quodammodo amans ab amato quadam intrinseca motione. Unde cum movens contingat id quod movetur, necesse est amatum intrinsecum esse amanti. Deus autem sicut intelligit seipsum, ita necesse est quod seipsum amet: bonum enim intellectum secundum se amabile est. Est igitur Deus in seipso tanquam amatum in amante. Thomas Aquinas, Compendium Theologiae, 1.45. http://www.corpusthomisticum.org/ott101.html\#70048.
} 
history's first articulation of a phenomenology of relationship. Thomas articulated a radically relational account of ethical and theological existence in 1273. Of course, it was not fully articulated, and its potential was not recognized. The fully formulated relational account of ethical and theological signification was not articulated until 701 years later when Levinas wrote "Otherwise Than Being or Beyond Essence". Yet, Thomas' Compendium clearly reflects the emotion of his mystical encounters. In Chapter 45 of his Compendium Theologiae entitled "That God is in Himself as the Beloved in the Lover", Thomas, who by the time he was 49 had written $8,000,000$ words, presents his most revolutionary thought in a mere 65 words.

He concludes this chapter with the words "est igitur Deus in seipso tanquam amatum in amante". "Consequently, God is in himself as beloved in lover". This philosophical description of existence is relational before it is ontological. The unmoved mover is moved. The agent, lover, is moved by the goodness of the patient, the beloved. Is this an ontological metaphysic? God does not seem to be described on the basis of his Being but on the basis of his relationality. This is a God of infinite generosity, of infinite self-giving loveableness, a God of infinitely motivating goodness who inspires by the goodness of his self-offering passivity, a Goodness for the other. This is not the God of Plato, Aristotle, Kant, Hegel, or even Heidegger. This is a God of infinitely passive relationality. A sense of God that was not put into words until Levinas wrote "Totality and infinity". ${ }^{672}$ Yet caution is required, at least in one respect. On other occasions, in earlier treatments of relationship in God, Thomas uses the expression "Beloved and Lover". Therefore, as radical as this passage is, Thomas has not necessarily abandoned his explicit ontological framework. But the question arises: can this expression of his thinking remain within the boundaries of his metaphysics? He has arrived at a profoundly relational articulation of existence. The good is both related to and relator, beloved and lover. Surely this is an articulation of the sense of absolute givenness, revealed in the eucharist?

(b) Of Being and Relationship

Perhaps the most extraordinary expression in Chapter 45 of Thomas' Compendium Theologiae is the idea that God is moved ("movetur"). Traditional Thomists can escape the assertion that this is problematic. They may argue that Thomas has asserted that the unmoved

672 "Totality and infinity": an essay in exteriority" (1961). 
mover is moved, but he has done so analogously. Therefore, they may claim, when Thomas writes "the lover is in some way moved by the beloved with a certain interior motion", this does not mean 'God as lover is actually moved by himself as beloved with a certain interior motion', but that something like this takes place in God.

In responding to this argument, an initial post Thomistic point needs to be made. Once analogy is invoked, it becomes as true to say 'something like movement takes place in God', as it is to say 'something like non-movement takes place in God'. It is impossible to argue to an ultimate position on the basis of analogy. The comparative pertinence of the terms can only be discovered as the analogies are applied to the appropriate fields of discovery. With reference to the infinite, at the beginning it is unknown whether the prime analogate should be rest or movement. However, it emerges that they both signify in different ways. So as the revelation of the infinite is explored, the different ways they pertain to the infinite emerge. Even though movement and rest are "in God" in ways that differ to the ways they are in creatures, the relative positions "movement" and "non-movement" intend genuinely applicable contents or attributes of God. They are meaningfully applied to God and as their application is held in tension, their meanings gradually emerge. But this is not the professed Thomistic approach. Thomas favours, or rather insists, on the doctrine that God is not moved. It is by force of evidence (historical revelation and mysticism) that Thomas' text has become weighted towards God being moved.

Of course Thomas, following Aristotle, argues that all movement is from potency to act. If a being lacks a certain perfection, it has the passive potential to be changed and proceed to that perfection. But in God there is no lack of perfection. God is the perfect fullness of Being. Therefore, there is no movement in $\operatorname{God}^{673}$.

In the Summa Theologiae, when addressing the question as to whether God is immutable, ${ }^{674}$ Thomas counters the objection that "Augustine says (Gen. ad lit viii, 20) 'the creator spirit moves himself neither by time nor space"”. Thomas replies, "Augustine there speaks in a similar way to Plato, who said that the first mover moves himself; calling every operation a movement, even as the acts of understanding, and willing, and loving are called movements. Therefore, because God understands and loves himself, in that respect they said that God

\footnotetext{
${ }^{673}$ Aquinas, Summa Theologica 1.9.1

${ }^{674}$ Aquinas, Summa Theologica 1.9.1
} 
moves himself, not however as movement and change belong to a thing existing in potentiality, as we now speak of change and movement." 675

There is nothing to argue against here. Thomas' response could easily be accepted as a way of teaching that there is a kind of movement in God and God is unchangeably loving. But this means love is dynamic, therefore God both changes and does not change, or, God is beyond both change and non-change. God's identity is infinitely active and dynamic. Thomas does not express the issues in this way. But at the basis of his thinking is the sense that movements of freedom are not expressions of a lack of perfection; they express the perfection of freedom. When Thomas writes "Liber est causa sui" 676 , the phrase "causa sui" may be translated "for its own sake". But this translation, while it suits Aristotle's doctrine of pure act, becomes problematic when Chapter 45 is explored more fully since it does not allow for the freely relational gifts through which "God understands and loves himself" 677.

However, Chapter 45 of the Compendium offers some reflections on "movement" in God, which are not covered in the Summa. At the heart of this chapter Thomas discloses a revealed relationship rather than a philosophical metaphysic.

A number of observations can be made on the unique features of this chapter within the Thomistic corpus. The first observation is that the Compendium appears to be unique in applying the passive "movetur" to God. Second, the text expresses a new kind of causality in which the agent is moved by the patient, the lover is moved by the beloved. This is a relational rather than ontological causality. Third, both the theological and philosophical ideas of relationship in God are voiced more clearly in this chapter than ever before in the history of metaphysics.

The fourth unique feature of Chapter 45 of Thomas' Compendium is that the classical structure expressed in Augustine's theology of the trinity is reversed. It is not the initial agency of the lover, but the inspiring loveableness of the beloved that motivates the trinity. Furthermore, the term "contact" ("contingat") or "touch" is used to describe the way in which the beloved moves the lover and this contact arises "within" ("intrinsecum") the lover. But contact or touch is a relational rather than an ontological occurrence. The relational givenness of intrinsic contact by the beloved motivates the agency of the lover. This calls the Thomistic

\footnotetext{
${ }^{675}$ Aquinas, Summa Theologica 1.9.1

${ }^{676}$ Aquinas, Summa Theologica I, 96. 4.

${ }^{677}$ Aquinas, Summa Theologica 1.9.1
} 
prioritising of an identified agent into question; yet it does so from within a Thomistic text. This requires some more explanation.

Thomas has taught in his discussion of the Trinity in the Summa Theologica that there are no processions in God except according to action ${ }^{678}$. The reason for this is that God is infinite perfection and therefore cannot move beyond himself. Rather God remains actively in himself. In the Compendium Thomas does not contradict this point. God is moved from within himself. But this does mean there is a movement in God which is not "according to action alone". This development in Thomas' text was close to the time that he died. However, through advances in the phenomenology of relationship it is not difficult to develop a reasonable solution to the problem. If, instead of defining God as pure act, God is described relationally, then it is easy to develop a sense of God as both agent and patient. God is ontologically active, but relationally God is both agent and patient. Both lover and beloved.

This relational priority in the genesis of the trinity is not an Aristotelian possibility that applies to the Being (Esse) of God. Rather, it implies that "Esse" is based in relationship. It also implies that rather than the Aristotelian a priori, where relationship depends on being, Thomas has articulated a relational priority such that, being depends on relationship. Will or freedom - is moved by loveableness. This suggests that the will is comprised of a passive and active relational dynamic. Confronted by Thomas' standard texts on the relational essence of the persons of the Trinity, this insight seems to demand a change in his metaphysics.

This chapter exposes the antinomy between movement and non-movement in God. The beloved, which is the loveable goodness of God, is at rest but God, as lover, moves for the sake of the immovable goodness of the beloved. Throughout the chapter, the discussion is manifestly phenomenological. It is not a metaphysical discussion of ultimate causes. It divulges a life of love. Were Thomas not so confident in his sense of God, he would not have arrived at this description of "the moving touch of the beloved in the lover". In the mind of Thomas, the mystical reflections or relational phenomenology at the heart of his discourses are more significant than his teachings on first causes.

Thomas' life, so profoundly reflective, reached a point where his affective-intellectual encounters with the infinite had ceased to coincide with his metaphysics. But this has not rendered his legacy inarticulate. Now, thanks to phenomenology, it is possible to revive his

${ }^{678}$ Summa Theologica, I q. 27, a. 3 c.: “... in divinis non est procession nisi secundum actionem” 
immense discoveries. This is necessary because Thomas' liberalism with "passivity" and "agency" in God involves discussions of the immanent life of God. These are of an entirely different nature to the act-potency issues that concern the differences between the creator and the creature.

The profound relational distinction between being at rest and being in movement, renders the eucharistic thought of Thomas Aquinas immeasurably more accessible than it has been to this point. It offers the way to an entirely relational understanding of his doctrine of the eucharistic change, or "transubstantiation".

(c) Relational and Temporal Issues Amidst Descriptions of Eternal Being and Identity

Part One of the Compendium, Chapter 45 shows Thomas at his most creative. By the time he came to write it, he had articulated the sense of Eucharistic change with an unprecedented depth of understanding. The inability of Aristotelian metaphysics to deal with these relational issues has highlighted Levinas' insight into traditional logic, that “since Plato's Republic, a genus of being's other has been lacking. ${ }^{679}$. A new intellectual field was required to process this depth of reflection. Thomas' late texts yield a strong sense of subjectivity - a phenomenological element - "The lover is in some way moved by the beloved with a certain interior motion" ${ }^{\prime 60}$. In order to access the phenomenological moments in Thomas' corpus, it is necessary to engage with phenomenology.

The heart of Thomas' thought flows through this passage. It is no accident that it is located in at the centre of his Trinitarian reflections. Thomas has just concluded his treatment of the Son ${ }^{681}$ and now begins his treatment of the Holy Spirit ${ }^{682}$. Whereas he treated the Son as the word that expresses the intellect of God, he treats the Holy Spirit as the love that expresses the will of God. As the word of truth is in the intellect, so the goodness of love is in the will. Where God is concerned, "to will" and "to be" are one and the same - "velle Dei est eius esse." ${ }^{683}$ Hence God is in himself as the beloved is in the will of the lover. It is the loveable good of the beloved that moves the lover ${ }^{684}$.

\footnotetext{
${ }^{679}$ Emmanuel Levinas, Autrement qu'être ou au-delà de l'essence. Paris: Kluwer Academic, 1990, 9.

${ }^{680} \mathrm{Cf}$, Thomas Aquinas, Compendium Theolgiae, 1, 45.

${ }^{681}$ Compendium 1:37-44.

${ }^{682}$ Compendium 1:45-49.

${ }^{683}$ Thomas Aquinas, Summa Contra Gentiles 4.19.7.

${ }^{684}$ Thomas Aquinas, Compendium Theolgiae, 1, 45
} 
The classic doctrine of the Trinity is often referred to as the psychological analogy. However, this does not do justice to the more basic metaphysical elements of self-related Being. Relationality is at the core of Thomas' Trinitarian thinking. Though Thomas did not initiate the relational emphasis, it has pervaded the tradition, particularly through Augustine. Augustine clarified the doctrine that relational differences are not caused by the essence of a being but by the fact that one being exists outside another. The Father has the unique name of Father, not because of his self-actualisation but because of the relational presence of the second person of the trinity, the Son. Thomas accepted this point but also gave more weight than Augustine to the essential constitution of the persons. In book 5 of "De Trinitate" Augustine described the one essence of the persons of the Trinity, while describing the different expressions of that essence according to the different relational givenness of each person $^{685}$. The relational givenness, differed not because of the self-causation of each person but because of the relational givenness of the others outside each person. ${ }^{686}$ Thomas, on the other hand, described the one essence as a relational essence. The different persons of the Trinity exist relationally not because of what is outside the being but because of the essence of their being. Their being is relationally self-causing. But because essence is so strongly tied to the sense of identity, Thomas' insistence on the relational sense of essence brought with it a bias towards identity ${ }^{687}$.

A Contrast to this bias is illustrated in a feature of Augustine's Confessions. In the Confessions, Augustine demonstrates the difference between the two-way relationship between God and God's creature. At the beginning of the Confessions, he makes his famous acclamation "you have made us for yourself O Lord, and our heart is restless until it rests in you" ${ }^{\prime 688}$. But the book concludes with another reference to rest. This time it is not about the human person seeking to rest in $\mathrm{God}^{689}$. It is about God coming to rest in the person, at the final Sabbath. This relational turn, is easier for Augustine, because of his sense that relationship is constituted outside the being that relates.

However, the relational paradigm does not figure as prominently in Aquinas because of his emphasis on identity. Aquinas' philosophy of relationship is grounded in his philosophy of

\footnotetext{
685 Augustine, De Trinitate, 5, In Patrologia Latina, vol. 42, Edited by Jacques Paul Migne. Paris: Garnies, 1880, http://www.augustinus.it/latino/trinita/index2.htm.

${ }^{686}$ Sed quia et pater non dicitur pater nisi ex eo quod est ei filius et filius non dicitur nisi ex eo quod habet patrem," Augustine, De Trinitate 5.5.

${ }^{687}$ Summa Theologica 1.39.

688 Augustine, Confessions, 1.1

689 Augustine, Confessions, 13:37.52
} 
the divine essence ${ }^{690}$. However, this is problematic because for Thomas, God's essence is also God's identity. Therefore, essence and identity are not radically distinguished in Thomas' metaphysical understanding. For him, essence is also agency. The divine essence actualises itself relationally. Essence actualises both identity and relationship but it is the actualisation of the relator which expresses relationship and identity. Prior to the Compendium Theologiae, the passivity of God, being related to is not expressed in Thomas' metaphysic. However, as his mystical life demonstrates, Thomas' openness to encounters with God overcame these limitations.

The expressions of divine passivity that emerge in Chapters 45 and 46 of the Compendium (Part 1) indicate that Thomas' immersion in relational issues takes him beyond the prescribed boundaries of his ontology. In fact, for all the problems it would have presented to Aristotle, a sense of relational passivity abounds in Thomas' doctrine of the Trinity, particularly in his last treatment. The task that Thomas bequeathed was to explore this relational emphasis so as to solve the ways in which essential and existential relationality would unite. One obvious challenge in doing so is to synthesise the infinite agency and infinite passivity that Thomas articulates in his text.

\section{(i) Temporal Relational Solutions in Thomas' Texts}

To this point the discussion has been concerned with two kinds of thinking: ontological metaphysical thinking and relational thinking. In the course of the discussion, two further points have emerged: first, that passivity is an imperfection for ontological metaphysics but a necessary perfection according to relational thinking. Second, Thomas Aquinas attempted to combine ontological and relational thinking by describing the Being of God as essentially a relational being. He made great progress in combining ontological and relational thinking but did not complete the synthesis.

The high point of Thomas' efforts occurred about the time he had completed his treatment of the Eucharist in the Summa Theologica. There he proposed that transubstantiation as a change more miraculous than any other change ${ }^{691}$. His treatment of this topic was not overt but

\footnotetext{
${ }^{690}$ Summa Theologica $1 ; 39$.

${ }^{691}$ Summa Theologica, 3.75. schema.
} 
slightly veiled. Another veiled discussion at this time was his treatment of passivity in God. In Chapter 45, Part 1 of the Compendium of Theology, Thomas says that "the lover [God] is moved by the beloved". This extraordinary passage seems to be the closest Thomas came to openly saying that "the unmoved mover is moved". As with the change that guided his discourse on the eucharist, this passage could also be treated as discussion of "the greatest of all changes".

At this time, Thomas had at least two overwhelming revelations. It was revelation that formed his thought, more than any other source. This is evident through the impact of the Eucharist on his teaching and personal spirituality. He did not think the Eucharist in terms of metaphysical categories but in terms of a change that was inconceivable to abstract metaphysics. He could only think the change more miraculous than any other change because he had a concrete sense of the power of change in the Eucharist. This was not a work of deductive metaphysical thinking proceeding from first principles. It was a work of revolutionary existential reflection based in the historical formation of his faith community and profoundly accepted religious beliefs.

(ii) Active and Passive Syntheses in St. Thomas

Although the distinction between active and passive syntheses was not known in his day, Thomas' writing on the Trinity exhibits an extraordinary appreciation of the difference and inalienable bond between active and passive syntheses. His treatment of the Trinity showed his sense that they function in different ways. The most profound element in Thomas' revolutionary text (Compendium Theologiae Part 1, Ch 45) is the use of the expression "bonum amabile est". The revolution consists in articulating the basis of God's existence, not in the infinite goodness of loving and the fullness of agency, but in the infinite loveableness of the Good and the depth of passivity.

Since the issues unfold so profoundly in Thomas' corpus, it is valuable to explore the distinctions between passivity and agency with regard to the eucharist and the relational discourse that pertains to the Eucharist and the Trinity.

In Thomas' thinking about the Trinity, the passive synthesis produces the processions of the Holy Spirit. In his thinking about the Eucharist, the passive synthesis produces changes in the status of the accidents of bread and wine. Both The Holy Spirit and the Eucharist provide an 
infinite terminus a quo, which, as terminus a quo, is passive to the result for which it is terminus a quo. This is not necessarily an ontological passivity. An origin can actively produce an end, but it is a relational passivity, an origin becomes an origin, only if results from that origin. This point provides the key to the connections between the doctrines of the Trinity and the doctrines of the Eucharist. They are both based in the passivity of relational consecration. In discussing liturgical consecration Thomas taught that "Christ is not in the sacrament in himself". "In himself he is in heaven but he is in the Sacrament according to a certain relation to it". The word for relation is "habitudo". It concerns the way Christ "has" himself towards the sacrament. ${ }^{692}$ But the having in "habitude" is an ad quem outcome for self-possessing identity. It is an expression of agency rather than passivity. Is there any reason why Thomas could not use the word "lassitudo"? Is loveableness defined by "having" or by "accepting", including the acceptance of relationship?

This is the issue of consecration. The argument put forward for consecration in this text is that consecration occurs because of the loveableness of the other. The passivity of the one for the other is consecration. Therefore, when the unmoved mover, the lover, is moved toward the beloved the unmoved mover is consecrated. Does this mean the consecration is involuntary for the one who is moved? No. But it means the agent-lover is voluntarily open to being moved by the patient-beloved. The first commonality among the persons of the trinity is that of loving one another through openness to being loved. This idea articulates the sense of the goodness of being a pure gift for the holiness of the other. By consenting to the goodness of the other and thereby becoming moved relationally by the other the one becomes consecrated for the other. To be relationally moved by the other is to be consecrated for the other.

Does this mean the Father must be consecrated? No, each member of the Trinity is selfconsecrating holiness, which also means infinitely loveable to itself. But each member of the Trinity is also relationally consecrated to and by the other members of the Trinity. The members of the Trinity consecrate their relationality as well as their identities. This dynamic will be clarified further in the conclusion of this thesis.

${ }^{692}$ Summa Theologica, III, 76, 6, co. 
(iii) The Act of Relational Acceptance as the Performance of Agency in the Trinity

The topic of relational acceptance in the Trinity may be approached through the concept "causa sui". "liber est causa sui" may be translated "that is free which is for its own sake". But in relation to the Trinity, as described by Thomas in Chapter 45 Part 1 of the Compendium that is an impossible translation. In one sense the lover moved by the beloved is causa sui because it is the essence of the lover to love. But in another sense, it is not causa sui because the lover is moved by the "contact" of the beloved. Thomas had not abandoned his standard uses of "causa sui" for the sake of the Compendium. He was always committed to the idea of God as a simply relational essence: 'it is the essence of the lover to love'. But the developments in the Compendium show that it had become necessary for him to rethink, and re-articulate, his doctrine of the relationships between agency and passivity in the Trinity. He did not have time to do this. However, one fairly simple corollary to Part 1, Chapter 45 of the Compendium would be a re-translation of "causa sui". A correct interpretative translation of Thomas' doctrine of relational essence would be "that is free which is simply for the loveableness of the beloved". This does not reduce the doctrine of the free agency of God, but would eliminate the interpretation of the agent. The 'actus purus' would be the individuals' acceptance of their common relational essence. The acceptance of the self as one-for-theother would be the act of consecration or, to use a Thomistic turn of phrase, the essential act of divine holiness. The acceptance of one's infinite relationality for another demands an infinite act of acceptance, acceptance of the unconditional relationality of the one for the other.

(vi) The Predilective Character of Consecration: a Trinitarian Theory of Consecration

In the Trinity the infinite diachrony of eternal holiness operates through predilective bonds. If the Trinity were temporal, each person would reveal their consecrated life predilectively. Consecration would be a predilective offering to the freedom of the other. This sense of offering shows the movements of God through history to be predilective consecration. The one is always already consecrated to the other in a relationship that liberates the other to accept. The joy is two-fold: the joy of freely celebrating the other's freedom and the joy of being loved by the other in the outpouring of freedom for the other. 


\section{Part D: Relationship and the Eucharist}

This section foreshadows arguments presented in Chapter Four which show how traditioning occurs through the sacrament.

\section{The Infinition of the Terminus a Quo}

Consecration is the acceptance of the relationality of the self, namely acceptance of the self as one-for-the-other. Just as the relational gift of the self is the terminus a quo for the life of relationship, so the bread and wine become the relational gift of one-for-the-other in the Eucharist. The revelation of the consecrated self is expressed by the signs of bread and wine. This is so for Jesus, but also for the disciples. The depth of the consecration is revealed through the death and resurrection of Jesus. The body of Jesus and the bread and wine become the self as the terminus a quo in the consecrated gift of self.

The previous reflections on the Eucharist, and on the Trinity have been concerned with the greatest of all changes. The striking thing about the descriptions of change that unfolded through reflection on those matters was that the change concerned the alteration of a "terminus a quo". An orientation towards a terminus ad quem, to an end to be attained, was transformed into the infinite alteration of a terminus a quo. The passivity of the signs of bread and wine became the gift of relationship in the Eucharist. Agency of the unmoved mover became altered by the loveableness of the beloved. It became a gift of relationship for the other one to whom the other would belong as term in a relationship.

This ever-deepening movement of the terminus a quo as an inexhaustible beginning for the other is also expressed by Levinas when he describes proximity. He wrote, "proximity is not a simply asymptotic approach concerning its term. Its term is not an end. The more I respond the more I am responsible. The more I approach the neighbour who is my charge, the more distant I am. Passivity which increases: the infinite as the infinition of the infinite, a glory., 693

These words by Levinas seem applicable to the Thomistic sense of the accidents of bread and wine. A finite terminus a quo, which is offered to the infinite becomes an infinite terminus a quo.

\footnotetext{
${ }^{693}$ Levinas, Autrement que.. "la proximité n'est pas une approche simplement asymptote de son 'terme'. Son terme n'est pas une fin. Plus je répond et plus je suis responsable; plus j'approche du prochain dont j'ai la charge et plus je suis loin. Passif qui s'accroit: l'infini comme infinition de l'infini, comme gloire" 149.
} 
Levinas offers a way of describing the infinition of the terminus a quo, the most miraculous of all changes, through the phenomenology of the subject rather than through the metaphysics of the sacrament. The previous section of this chapter has also shown that the more radical the metaphysical appreciation of the Eucharist becomes, the more it moves away from a metaphysic of Being to a metaphysic and phenomenology of relationship. Although Thomas Aquinas began expressing such a metaphysic in 1274, the demonstration of the relational basis for meaningful events was not provided until 1974, when Levinas wrote Autrement qu'être ou au-delà de l'essence. There he describes an horizon of intellectual expression which, according to him has been needed since Plato referred to "the Good beyond essence" in book seven of the Republic ${ }^{694}$. This thesis seeks to stay in that same horizon and pays particular attention to the sense of the passive synthesis in both Thomas and Levinas. But also. The passive sense of syntheses has also been explored in relation to the scriptures. With this in mind it is valuable to consider the relationship between the passive synthesis and Jeremias' understanding of the Last Supper Eucharist.

\section{Zeker-anamnesis}

(a) Re-asserting the Achievements of Jeremias

A study of Jeremias' work, The Eucharistic Words of Jesus ${ }^{695}$ offers a new way of thinking "anamnesis". This is due to Jeremias' emphasis on the passive synthesis of being remembered by God, "that God may remember me" 696 rather than the active synthesis of remembering. This supports Levinas' opposition to the idea that active remembrance is ethical. Similarly, Levinas' emphasis on subjective passivity supports Jeremias' teaching that Biblical remembrance involves, first and foremost the passivity of being remembered by God.

The idea of a relationally defined Eucharist, promotes the relational sense of being remembered by another. This not only brings a new ability to re-assert and advance the achievements of Jeremias, it also exposes the problem that the lack of awareness of various categories of interpretation, has imposed on the history of biblical exegesis. The teaching of Joachim Jeremias that "do this in memory of me" meant "do this that God may remember

\footnotetext{
${ }^{694}$ Autrement que, 13.

${ }^{695}$ Joachim Jeremias, The Eucharistic Words of Jesus, Translated by Norman Perrin, New York: Scribner, 1976.

${ }^{696}$ Jeremias, "Eucharistic Words", 237.
} 
me" $(1960)^{697}$ reveals his preference for a Jewish - relational - rather than a Greek ontological - doctrine of memory. But his teaching has gained little ground in the last 68 years of research. The problem is that Western religious thought is profoundly ontological. This point can be discerned through a brief analysis of Conzelmann's ${ }^{698}$ argument against Jeremias.

In his response to Jeremias, Conzelmann wrote "this interpretation is in contradiction to the plain wording...'in remembrance of me..." "699 In point of fact Conzelmann's “in remembrance of me" neglects the article " $\tau \grave{\eta} \nu$ " ("in the remembrance of me"), but more importantly this translation pays no deference to the Hebrew "zeker" ("memory"). Instead there is a naive predilection for the Greek language. The tradition of God's memory expressed through "zeker" is reduced to the koine Greek usage of "anamnesis". But this naivety is symptomatic of ontological priorities. It is basic to Conzelmann's argument that the "plain sense of 'remembrance' (which should be rendered "the remembrance") is expressed by the human act of remembering. It gives no consideration to the ways in which "in the remembrance" involves the passivity of being remembered. It relies exclusively on the classical ontological starting point - agency. But this is no argument against Jeremias' biblically based linguistics. In an attempt to save the ontological objection it may be allowed that, perhaps First Corinthians 11:24-5 prioritizes the agency of faith and that God responds to acts of faith with the utmost generosity. But the sense of "the remembrance" itself is still limited to the Church's and the disciple's remembering God. This has to be an impoverishment. Remembering by God, and therefore being remembered by God is absolutely indispensable to the Jewish covenant. How could Moses have appealed to God's memory if he did not think God's people were remembered by God? ${ }^{700}$ Furthermore, the sense of God remembering, and of being remembered by God is shown in many texts of the Jewish Testament. Jeremiah 31:20 expresses it with particular clarity and depth. "Is Ephraim my dear son? Is he a delightful child? Indeed, as often as I have spoken against him I certainly still remember him" (Jer 31:20).

The error in the ontological, agency-based approach to the Eucharist is subtle, and may even distort the idea of God remembering. A deeper reflection on Jeremiah 31:20, including its

\footnotetext{
${ }^{697}$ Eucharistic Words, 8.

${ }^{698}$ Conzelmann, Hans. 1 Corinthians: A Commentary on the First Epistle to the Corinthians. Translated by James W. Leitch. Edited by George W. McRae. Philadelphia: Fortress Press, 2008.

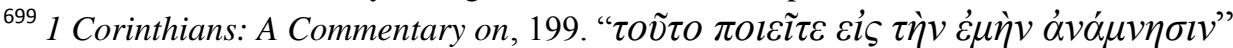

${ }^{700}$ Ex 32:4.
} 
final sentence clarifies the point. "Is Ephraim my dear son? Is he a delightful child? Indeed, as often as I have spoken against him I certainly still remember him. Therefore my bowels are troubled for him" (Jer 31:20). This final sentence articulates the sense of God's passivity. Like the prodigal father who is continuously distressed about his errant son, here Jeremiah's text demonstrates God's invincible vulnerability. Ephraim, who is remembered by God, is bound in the passivity of being remembered by God. But also God, is bound in the passivity of an unforgettable concern for Ephraim.

Even when applied to God, the key to the relational sense of remembering consists not in the power of the agent (the relator) to remember, but in the power of the patient (the related to) to be disturbingly unforgettable. It is not God's self-determining power that produces God's covenantal remembering; it is God's insuperably troubled passivity in regard to Ephraim that sustains the remembrance of God. The remembering of God, like the remembering of the prodigal father, goes beyond consideration of the actions and chosen ways of his son. It refers to the imposing force of his son's passivity, Ephraim's precarious yet invincible loveableness. It is passivity, the weak yet imposing passivity of the beloved child that alters the agency of the father and renders it relational.

The neglect of this relationality in the name of the father's sovereign power distorts the idea of God remembering. God does not offer his eternal covenantal remembering as a sign of his great formative power. Rather God's covenantal memory bursts from his heart as a sign of weakness. God's weakness for his irresistible beloved. Paul would treat this as, a weakness "stronger than human strength"701.

But it is somewhat optimistic to discuss distortions in the idea of God remembering. First it must be acknowledged that, outside the influence of Jeremias, the idea of 'God remembering' at all is entirely foreign to the vast array of reflections on the

Eucharist, from the ancient to the contemporary, the conservative to the revolutionary. Hence in naively arguing against Jeremias, Conzelmann has merely displayed the problematic habit of the ontological approach. Therefore, the argument in favour of Jeremias' theory, taken up in this thesis, counters the ubiquitous act-based ontological treatments of memory and the fight for the almost universally neglected passivity-based relational senses of memory. It is tragic to think that the supreme articulation of memory in the Bible - the memory of God - is neither applied to nor explored through the Eucharist.

701 Cor 1:25. 
(b) 'Memory' in Levinas and Jeremias

This thesis' phenomenological approach to the Eucharist requires a combination of Jeremiasian and Levinasian themes. However, the fact that they treat 'memory' very differently may obstruct the application of the sense of God's memory to the Eucharist. Levinas has been so critical of memory as an unethical ontological achievement that he gives it very few positive treatments. Rather, he treats forgetting more favourably than he treats remembering. ${ }^{702}$ On the other hand, Jeremias treats memory very positively. However, it is important to bear in mind that Levinas radically distinguishes his philosophical from his religious treatments of 'memory'. In its philosophical occurrences, he generally describes memory as ontological and unethical. "Beings remain always gathered,-= present - but in a present extending itself thanks to memory and history, to a totality which is determined like matter." ${ }^{, 703}$ But leaving philosophy, "memory" has a very high priority in his lived ethics, his religion. The Hebrew dedication inside the opening cover of "Otherwise Than Being or Beyond Essence" is written, in Hebrew, to the memory ("lzkr") of his parents, siblings and other close family members. ${ }^{704}$ The French dedication is more publicly formal, but it is also written "à la memoire" of" those who have suffered from the same "antisemitism" as his family members, "the same hatred of the other man"705

In "Levinas, Memory and the Art of Writing"706 Annabelle Herzog has drawn attention to these two very different philosophical and religious treatments of 'memory' by Levinas. "In doing so, she has prompted rich reflections on religious memory. This thesis recognises the religious sense of memory in Levinas and therefore argues that memory in Jeremias and Levinas may be reconciled because both speak of religious memory in a positive way. This sustains Levinas' condemnation of the naive ontological preference for "remembering" while applying his prioritisation of religious or radically relational remembrance.

\footnotetext{
702 "un oubli qui serait une ignorance au sens où .... certain monothéistes ne reconnaissent pas, tout en le connaissent, ce qui n'est pas le plus haut." Autrement qu', 272.

${ }^{703}$ Autrement qu', 16.

${ }^{704}$ Autrement qu', dedication page

705 Autrement qu', dedication page

${ }^{706}$ Annabel Herzog, "Levinas, memory, and the art of writing." In The philosophical forum, vol. 36, no. 3, 333343. Oxford, UK and Malden, USA: Blackwell Publishing Ltd., 2005.
} 
(c) Anamnesis: an Institutional Placement of Zeker-predilection

Furthermore, the idea of passive relational remembrance makes more sense once the idea of infinite predilection is articulated. On this basis, the sense of a passive synthesis provides a new way of thinking anamnesis. Along with supporting Levinas' opposition to the idea that active remembrance is ethical and supporting Jeremias' teaching that Biblical remembrance involves, first and foremost, God's remembrance of God's unforgettable people, it also introduces the way Levinas' notion of "the third" can be accounted for as a gift of relational traditioning. In terms of its passive givenness the loveableness of the third has a formative role in the traditioning of the Eucharist and of traditioning generally. The idea of the third will be explored in Chapter 4 but it also belongs in these concluding reflections on the Eucharist itself.

Seeing his mother and the Beloved Disciple standing at the foot of the cross, Jesus said "Woman behold your son. Son behold your mother.",707 In saying these words, Jesus transforms the individual relationship of each disciple with Jesus into a communal relationship. For Mary, the Beloved Disciple is the third and for the Beloved Disciple Mary is the third. Therefore, the loveableness of the third, declared for each disciple, by Jesus, has a formative role in the dynamic of traditioning. This, of course, applies to the traditioning of the Eucharist.

Again, there are correlations, this time between Levinas' descriptions of incarnate relational passivity and the sacramental imagery in John's Gospel, of "blood and water flowing from the side "of Christ." ${ }^{708}$ Near the end of the Chapter 3 on "Proximité" Levinas speaks of "the passivity more passive than all passivity antithetical to an act". He describes it as "vulnerability and suffering being sapped like a haemorrhage ... exposing its very exposition ... - being expressed- speaking - ... passivity of being-for-the-other which is only possible under the species of giving the very bread that I eat." ${ }^{709}$

The depth of subjectivity in that imagery draws on two images that pertain to the Eucharist. Firstly the sacraments flowing from the side of Christ on the Cross, seem to resonate with Levinas' description of a vulnerability being sapped with suffering, and haemorrhaging in its

\footnotetext{
707 Jn 19:26-27.

${ }^{708}$ Jn 19:34.

${ }^{709}$ Autrement qu' 116.
} 
extirpation for the other. The other sacramental image is that of bread, the very bread that I eat, that has my life in it, being given for another. This resounds with the sense of the Eucharist. Through these two images, united in one sentence, the two horizons of the Eucharistic consecration are articulated. Subjective consecration, through the pouring out of the blood of Jesus on the Cross. And institutional consecration, through his giving of bread as a sign of his own self-giving. The two horizons of consecration, subjective (on and at the foot of the cross) the cross, reflect the radical power of love in the relationally consecrated subjectivity of the one-for-the-other. The one is consecrated by the suffering of the other. The sense of institutional consecration is reflected in Levinas' use of the image "bread". This image figures outside the imagery of the haemorrhaging subjectivity and articulates the sense that, in the institutional sign of bread (and wine) the subjective consecration of the one and the other as one-for-the-other is extended and extroverted into a consecration for the third. This puts hospitality of others for another, at the root of Eucharistic traditioning. It is expressed in the maternity of the mother of Jesus for the Beloved Disciple and the hospitality of the Beloved Disciple. Each one carries a gift of relationship, from Jesus for the other and thereby lives in a relationship, outside themselves that he has entrusted or traditioned to them.

\section{Conclusion}

This chapter has shown that the Eucharist is a relational sign. That is not a new insight. However the chapter has also explored the identity of the Eucharist. The goal has been to discover how the Eucharist temporalizes. With regard to the early centuries of its formation it has not been surprising to find that the Eucharist temporalizes. But when the Eucharist of St Thomas Aquinas was explored it was surprising, that a Eucharist so metaphysically established should still be based in change and relationality. Not only that, a further surprise, at least to this author, has been to discover the significance of the Eucharist as a terminus a quo. It is as though the Eucharist reveals God as an eternal beginning. This turn towards the beginning is compatible with Levinas writings on proximity. Together the contributions of St Thomas and Levinas confirm each other in a new approach to traditioning, a traditioning that prioritizes the terminus a quo as gift of loveableness for the other. The infinition of the terminus a quo, transforms the other through its infinite relationality, and supports the other in the bond with a third, always bringing forth the infinite gift of relationship. This insight will be pursued further in the following chapter. It will also be applied to further clarify the ways infinite passivity applies in the Eucharist and the Trinity. 


\section{Chapter 4}

\section{A Phenomenology of Traditioning}

\section{Introduction}

This chapter is a phenomenological reflection on traditioning. The previous chapter has described the Eucharist as an expression of the acceptance of being related to in a covenant relationship. This led to an articulation of the Eucharist as a sign of relationship. The argument so far demonstrates that, at its core, the Eucharist signifies temporally and relationally. But has the Eucharist been treated according to its significance? The Eucharist is a traditional sign; it figures as an expression of existence in ongoing historical communities. Yet, in this thesis, the ideas of a 'traditional sign' and 'traditional signification' have not been described outside the history of the Eucharist. This does not mean that the study has been void of reflection on tradition. The previous chapters have shown that the historical origins of the Eucharist were rooted in traditioning. Nevertheless, the idea of tradition has proven to be problematic. Chapter 3 led to the observation that, according to the tradition of the sacrament, Jesus himself, the supreme celebrant, comes to the Eucharist on the basis of his relational passivity or sacrifice for the other. However, this exposes the ancient problem of "traditioning". How may the relational sense of traditioning be free from entrapment in the identities of traditions?

An influential moment in the history of the Eucharist was examined in Chapter 2. Cyprian ${ }^{710}$ changed the way that tradition was spoken about. Where Paul used the verb - "What I received from the Lord I traditioned to you" (1 Cor 11:23), Cyprian substituted a noun and wrote of "the tradition of the Lord". Cyprian's nominalization - galvanizing though it was initiated the suppression of two elements intrinsic to the Eucharist. Firstly, the Eucharist became objectively identifiable, therefore it became instrumental in a turn toward an

\footnotetext{
${ }^{710}$ Cyprian, "Epistle LXII" (English) and "Epistula LXIII" (Latin). Note different numbering in the English (ANF) and Latin (CSCO) editions of Cyprian's writings due to Ad Donatum being included as Epistle I in the latter. Cyprian Epistle to Caecillius of Bilthra, 2.
} 
institutional rather than a relational ethos of the sacrament. Secondly, it established the sense that the Eucharist was a changeless historical fact, not contingent on the temporal practices of those who traditioned it. Rather it was considered dependent on the eternal and unchanging authority of the Lord. It was an eternally identified tradition. This chapter seeks to overcome the severing between intersubjective relationality and external tradition by exploring, phenomenologically, the subjectively relational and the historical dynamics of traditioning.

\section{Part A: Subjectivity and Tradition}

\section{Basic Concepts}

This thesis operates on the working hypothesis that Heidegger's distinction between the "possible" and the "impossible" can be understood through the phenomenological distinction between a sense and a sense bearer. Among other things this chapter provides an argument that when Heidegger and post-Heideggerians use the term "possibility", they are referring to 'a sense that is supported by a sense bearer', and when they use the term "impossibility", they are referring to 'a sense without a sense-bearer'. Scheler, in his "Ethics", 711 was the first to apply the distinction between a "sense" and a "sense-bearer" comprehensively, to all kinds of phenomena. His main use was in ethics. There he voiced this distinction by distinguishing between a "value" and a "value-bearer". 712

In this thesis, "sense" is used to include both values and other kinds of sense. Heidegger used "Sinn" in "Sinn von Sein" to comprehend both value and veracity" . The French philosophers in the phenomenological tradition also use "sense" ("sens"), "signification" ("signification") and "meaning" ("sens") in the same comprehensive way but with greater emphasis on the ethical rather than the veracious aspects of sens. For Heidegger, the question of meaning is ontologically prior to ethics. This does not mean meaning is without value, but that meaning includes value. It expresses care ${ }^{714}$. In this thesis, the main reason for the

\footnotetext{
${ }^{711}$ Max Scheler, Der Formalismus in der Ethik und die material Wertethik: Neuer Versuch der Grundlegung eines ethischen Personalismus. With an appendix by Maria Scheler. Edited by Manfred S. Frings. Bonn: Bouvier Verlag, 2000. 103-104. Translated into English as Formalism in Ethics and NonFormal Ethics of Values: A New Attempt toward the Foundation of an Ethical Personalism. Translated by Manfred S. Frings and Roger L. Funk. Evanston: Northwestern University Press, 1973.

${ }^{712}$ Scheler, Der Formalismus, 103-104.

${ }^{713}$ For Heidegger the question of meaning is ontologically prior to ethics. This does not mean Being is without value, but that meaning expresses value. It expresses care. See Martin, Heidegger Sein und Zeit. Tübingen: Max Niemeyer Verlag, 2006, 180-184.

714 "The authentic potentiality-for-being-a-whole becomes visible as a mode of care. With this the
} 
distinction between a sense-bearer and a sense is to make the Heideggerian and postHeideggerian discussions (in this thesis) about "possibility" and "impossibility" easier to follow. This view is corroborated by the following passage from Levinas:

"If one had the right to retain a single trait from a system of philosophy, and neglect all the details of its architecture...we would think here of Kantism, which finds a meaning ("sens") for humanity without measuring it by ontology and by going outside the question "what's it

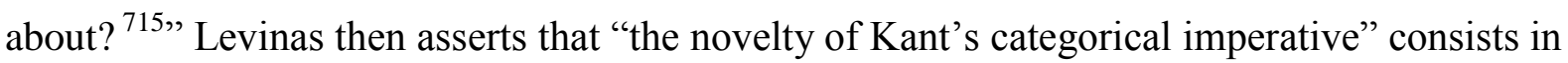
its expressing a meaning ("sens") which does not measure itself by being or non-being, but where, to the contrary, being is determined on the basis of meaning ("sens")"716.

This impossible sense without even 'being' as a sense-bearer indicates something of what Levinas meant by "God". A sense without a sense bearer, without even Being as a sense bearer. Rather, God transcends Being and reveals himself without the need for any attributes other than signification itself. But signification arises through relationship, through substitution.

To arrive at the idea of a sense without a sense-bearer it is helpful to return to Scheler's thumbnail sketch of phenomenology. In all areas of its investigations phenomenology performs "three kinds of distinction": (1) knowable events, (2) acts of intuition and (3) interconnections between the essences of events and acts ${ }^{717}$. The first two are variants on the familiar 'object-subject' account of consciousness. The third introduces the distinctive field of relationship. Scheler did not master this area, but adverted to it. His contribution here, is to have introduced the concept "between" ("zwischen"), introducing the sense of relationship as a distinctive horizon. Through his use of "between" ("zwischen"), he articulated a horizon that was neither subjective nor objective, neither consciousness nor being, neither intuition nor event, but a signifier that testifies to relationship. Buber and Levinas advanced the use of "zwischen" but Scheler's work remains indispensable because he initiated the treatment of "das Zwischen" as a necessary element in a thorough-going description of meaningful events.

In this thesis Scheler's attention to "the essential interconnections between essences of acts and of things,"718 (“die Wesenzusammenhänge zwischen Akt- und Sachwesenheit - Scheler

\footnotetext{
phenomenally adequate basis for a primordial interpretation of the meaning of Being of Da-sein is also secured, Martin, Heidegger. Sein und Zeit. Tübingen: Max Niemeyer Verlag, 2006, 234.

${ }^{715}$ Autrement qu', 205.

${ }^{716}$ Autrement qu', 205.

${ }^{717}$ Scheler, Der Formalismus, 90.

${ }^{718}$ Formalism, 72.
} 
italicises zwischen Akt- und Sachwesenheit) ${ }^{719}$ is very influential. At the time that he described "die Wesenzusammenhänge zwischen..." the sense of relationship had not been emancipated from the ontological environment in which it first emerged. Since then, advancing the tradition of Rosenzweig, Buber, Marcel, and other participants in the phenomenology of relationship, Levinas has radically distinguished the sense of relationship from the sense of Being. But, in the shadow of these contributions, Scheler's work has been overlooked. Nevertheless, his perspective remains necessary. Again, Scheler's contribution is not to the fore of the arguments that follow, but it does bring a necessary element, the idea of a positive sense without a sense-bearer, where "zwischen" exposes the idea of a sense that is not a sense bearer. This thesis explores the distinction between the related to and the relator on the basis of Scheler's unique introduction of "zwischen".

\section{Levinas and the Idea of God}

In "God and Philosophy"720, Levinas opened a way for phenomenological reflection on theological signifiers. He analysed the Descartes treatment of the "idea of the infinite". ${ }^{721} \mathrm{He}$ did not treat the idea as Descartes had, as a basis for the ontological argument for the existence of God. But he reflected on it as an inexplicable and inextinguishable source of meaning and aspiration ${ }^{722}$. The crucial insight for Levinas was that the idea of the infinite is inseparable from the desire for the infinite ${ }^{723}$. But the infinite cannot be attained by finite desire. Therefore, the infinite is not directly attainable for a finite subject. The infinite does not neglect this problem but provides the desiring subject with a detour. Through the approach of the other, the infinite ("God") offers subjectivity an oblique, rather than a direct relational bond with itself, a desire separated from its goal. ${ }^{724}$ Through the forsaken stranger God offers an infinite relationship. ${ }^{725}$ This is not a relationship that goes from the finite subject to the infinite God, rather it comes from the infinite (God) to the finite (subject), through the approach of the other. It doesn't fulfil the desire of the finite, but nurtures an infinite desire in the finite subject through imparting to the finite an infinite responsibility for

\footnotetext{
${ }^{719}$ Scheler, Der Formalismus 90.

${ }^{720}$ Emmanuel Levinas. "God and Philosophy” translated by in The Levinas Reader, ed Sean Hand, Oxford: Basil Blackwell 1989, 167-189.

721 "God and Philosophy", 173.

722 "God and Philosophy", 173.

723 "God and Philosophy", 178.

724 "God and Philosophy”, 178

725 "The desirable orders me to the non-desirable, the undesirable par excellence - the other." "God and Philosophy”, 178.
} 
the other who approaches. Through the approach of the other, the subject desiring the infinite is bound to the infinite through the responsibility of love. ${ }^{726}$

Levinas develops an existential theological ethos, without attributing any positive act of existence to the infinite. This is worth exploring. Existence signifies through subjective sociality not through the infinite. This deft manoeuvre enables Levinas to articulate the sense of God and God's goodness in a way that does not rely on lesser discussions about sensebearers and the evidence for God's existence. The subject is historically responsible for the other because the infinite transcends history and, in doing so, has left a trace of holiness in the subject. This sense of holiness comes to expression through the approach of the other. ${ }^{727}$ This approach is an approach from God, a plea from God to bless the approaching stranger with the goodness of hospitality.

\section{Levinas and Derrida}

Levinas' ideas are challenging to a conventional theology. To understand his work more clearly it is worth comparing his philosophy with Derrida's.

There dialogue was complex. In "Proper Names”, Levinas described Derrida's deconstructive thought as "ontologie" 728 . Levinas does not explain what he meant by this; furthermore, it is difficult to find other texts in which he finds fault with Derrida. The fact that they were such good friends adds to the confusion. Could they have conversed so well if Derrida was only talking ontology? The simple way to address the seeming inconsistencies between Levinas' charge against Derrida and the counter-ontological character of their communication is to assert that Derrida's thought was not only ontology and not always ontology. However - if Levinas' criticism is to be taken seriously - sometimes, Derrida's thought must have been what Levinas meant by "ontology". However, it must also be acknowledged that Derrida's thought changed. The idea of the arrivant cannot be accounted for on the basis of ontology. On the other hand, it is an idea that came to him late in his life, ${ }^{729}$ years into his conversations with Levinas. Furthermore, "l'arrivant" does not seem to bring an end to ontology in Derrida. Paradoxically, the problem of ontology arises in a text full of relational pathos, in Derrida's

\footnotetext{
726 "God and Philosophy"179.

727 "God and Philosophy", 178.

${ }^{728}$ Emmanuel Levinas. Noms propres. Montpellier: Fata Morgana, 1976, 88.

${ }^{729}$ Cf below, 233.
} 
eulogy for Levinas, published as "Adieu to Levinas"730. In the eulogy, Derrida fulfils his philosophical duty and demonstrates the difference between his philosophy and that of his friend, not that he makes the difference obvious. This is not inappropriate. Obscure disagreement was part of their friendship. It is also a matter that contributes to this thesis. Not that Levinas' critique of Derrida is the goal of this thesis. Its goal is to advert to a sense of love that is relational rather than ontological, one that exceeds the meaning of 'Being'. The fact that their friendship went beyond - even celebrated - their philosophical differences is more to the point. But, even for the sake of that celebration, it is helpful to explore their philosophical differences. It is also helpful, in the quest to understand Levinas, to learn what Levinas meant in his charge against Derrida, "ontologie"!

To begin with some differences. The difference between Derridean deconstruction and Levinas' phenomenological reduction can be accessed by applying the distinction of a "sense" and a "sense-bearer". This distinction leads to an understanding of ontology which may account for what Levinas meant when he accused Derrida of being an ontological thinker.

This Schelerian path relates to a clear grammatical difference between the two philosophers. Levinas' accounts for meaning on the basis of "l'impossibilité de tout possibilité",731 and Derrida's treats meaning on the basis of "the possibility of impossibility" ${ }^{732}$. Levinas expressed "the impossibility of all possibility" in clear contrast to Heidegger, who, in "Being and Time" had treated "being-towards-death" as "the possibility of impossibility" ${ }^{733}$ On the other hand, Derrida, dispersed the issue asking if "finitude is "possibilité comme crise? Une certaine identité de la conscience de crise et de l'oubli de la crise?"734 But as his life progressed he concentrated more directly on "the possibility of impossibility". The differences between Levinas' “impossibility of possibility" and Derrida's "possibility of impossibility" were sustained by both authors right through their lives. In Entre Nous (1991), Levinas was still discussing "the impossibility of possibility",735. In 1993 it seemed to govern the contours of Derrida's "Aporias". ${ }^{736}$ There may have been something of a protest against

\footnotetext{
${ }^{730}$ Jacques, Derrida. Adieu à Emmanuel Levinas. Paris: Galilée, 1997.

${ }^{731}$ Levinas, Totalité et infini: Essai sur l'extériorité. Paris: Kluwer Academic, 1990, 262.

732 "The ultimate aporia is the impossibility of the aporia as such.... Death, as the possibility of the impossible as such, is a figure of the aporia..." Jacque, Derrida. Aporias: Dying-Awaiting (One Another at) the "Limits of Truth”. Translated by Thomas Dutoit. Stanford, CA: Stanford University Press, 1993, 78.

733 "Der Tod ist die Möglichkeit der schlechtinnigen Daseinsunmöglichkeit”. Heidegger, Sein und Zeit, 250.

${ }^{734}$ Jacques Derrida, L'écriture et la difference, Paris: Éditions du Seuil, 1967, 97.

${ }^{735}$ Emmanuel Levinas, Entre nous. Paris: Grasset, 1991, 226.

${ }^{736}$ Aporias: Dying-Awaiting, (One Another at), 78.
} 
each other in this distinction, but whatever it may say about their conversation it makes it quite clear that Derrida sustained the effort to think through the Heideggerian discovery of the problematic while Levinas thought an alternative to that problematic. Given that, in terms of the history of philosophy they drew on different roots, is it possible to find a way of comprehending their conversation? Using Scheler's distinction between a "sense" and a "sense-bearer" and his introduction of the term "between" it may be possible to bring the conversation into some clearer parameters.

In clarifying the difference between Levinas and Derrida by arguing that they articulate a different kind of connection between senses and sense-bearers, this conversation has to take the risk of articulating their thought in a pre-Heideggerian context, but that may be helpful, because they both, in different ways, break with Heidegger. The first point in this attempted paraphrase is to say that Levinas explores subjectivity as a sense-bearer that arises on the basis of an already past sense. "The idea of the infinite, infinity in me"737 the finite sensebearer, comes invested with a secret diachrony ${ }^{738}$. Although the finite cogito thinks the infinite, the idea of the infinite is not limited to the time that it arises in the cogito. It comes to the cogito with the overwhelming sense that it has always already been, before the time of the cogito. The cogitatum comprehends the cogitans ${ }^{739}$. Therefore, the idea of the infinite informs and overwhelms the finite with a sense that is not finite, it is pure relationality in the overwhelming sense of the infinite. The im-position of the infinite in the subject meant for Levinas that, the impossibility for thought is the impossibility of not thinking the infinite. Impossibility pre-empts every possibility. It may be said that the self is caught in the thought of the infinite. But this means that the infinite bears the finite, rather than the finite bears the infinite.

Levinas provides one of his clearest passages on the impact of "infinity in me" when he describes temporality in "On The Other in Proust" ${ }^{740}$. There he describes the temporality of conversation, a temporal process infused with an incomprehensible diachrony. "Forgetting turns away from the past instant, but keeps up a relation to what it turns away from when it abides in words. Thus is diachrony restored to time. A nocturnal time: 'night in which

\footnotetext{
${ }^{737}$ Levinas Reader, 174.

738 "On the Other in Proust" translated by Michael Holland in Levinas Reader, 159.

${ }^{739}$ Levinas Reader, 174.

740 Emmanuel Levinas, "On the Other in Proust", translator, Sean Hand in "The Levinas

Reader", 160-5.
} 
nothing is waited for represents this movement of waiting, ${ }^{741}$.... To wait for nothing and forget everything, the opposite of subjectivity, here is 'absence of all centre ${ }^{742, "}{ }^{743}$ The relational depth of this forgetting is given dramatic clarity when Levinas quotes Proust, "she has detached him from him, himself." "744 In terms of the Schelerian paraphrase attempted here, the horizons of time that defy reflection, figure as sense without a sense bearer. Such is "the idea of the infinite, infinity in me". 745

Differing from Levinas, a kind of interplay of possibility and impossibility governed Derrida's thinking. The following is an articulation of Derridean issues through the Schelerian philosophy of sense and sense bearers. In that sense it may be possible to describe thinking the possibility of impossibility as thinking that is concerned with meanings that break down when sense-bearers fail to sustain the senses they produce. The following discussion, seeks to account for this way of approaching Derrida and some ways he and Levinas differed.

In the Western tradition, the final sense-bearers may be called "Being" and/or "subjectivity" and/or "language". This thesis argues, in a way that claims to be Levinasian, that the senses that exceed sense-bearers may be called "transcendent" since they signify, of themselves, outside the horizons of sense bearers. This does not mean they do not also signify through sense bearers - the infinite through subjectivity - but it means their sense is not reliant on a sense bearer. The sense bearers arise and come to pass through the influence of a sense that arises outside them.

That senses arise outside of Being occasions the sense that Being is finite. This assertion must sound strange in the wake of protracted meditations on the Eucharist, John's Gospel, and ancient and mediaeval metaphysics. However, it means that relationship is greater than Being. Being is the ultimate bearer of the sense of identity. But identity becomes altered by relationship. Therefore, relationship is greater than Being. The limits of Being and beings allow relational possibilities outside the possibilities of Being. Thus, relationship and God are outside of sense bearers. Relationship arises on the side of the subject in the form of hope. God arrives from outside the subject, overwhelming the relational aspirations of the subject, in the form of a hope-against-hope. These dynamics move from the hopeful possibility of

\footnotetext{
${ }^{741}$ Here Levinas quotes Proust.

${ }^{742}$ Here Levinas quotes Proust.

743 "On the Other in Proust" translated by Michael Holland in Levinas Reader, 155.

${ }^{744}$ Levinas Reader, 155.

${ }^{745}$ Levinas Reader, 174.
} 
impossibility to the counter-hopeful negation of possibility (the impossibility of possibility) in the overwhelming invasion of the infinite. The negation of possibility brings the gift of the infinite, pure relational signification. For Derrida, the negation of possibility is the destruction of the possible, while for Levinas, the negation of possibility is not the destruction but the alteration of the possible. As will be seen, Derrida's work developed towards Levinas' relational sense of altered possibility but never took the final step.

To appreciate their differences, it will be helpful to reflect on an aspect of Levinasian thought with which Derrida engages. The title for Derrida's eulogy for Levinas, “Adieu to Levinas" takes up Levinas' description of the relationship between subjectivity and alterity. Levinas observes that one says "à-Dieu",746 to another ("(go) to God"). The Levinasian understanding is that this saying is spoken out of passivity for the other. ${ }^{747}$ Because the other has gone to God, the subject becomes the speech that affirms their relationship with God.

Through this relational passivity, the subjectivity that is formed through relationship with the other expresses the meaning of the other. The subject becomes a word of infinite affection, commending the other to God, becomes one for the other's relationship with the infinite. The other's going to God is radically exterior to the subject's being. Derrida expresses this kind of commendation in his eulogy. He speaks of his "infinite sadness",748 and extols Levinas with moving affection. Their friendship is palpable in the text. Derrida says "we would often address each other in a way that I would neither call questions nor answers, but, perhaps to use another of his expressions, a sort of "question, prayer". ${ }^{749}$ It is very easy to hear the play of friendship in these words. Levinas speaks of a sort of "question, prayer". ${ }^{750}$ Levinas often uses a comma to advert to the differences and the similarities in words. The comma means they are closely related but must be thought differently. Derrida on the other hand speaks of a "question-prayer"751. The hyphen creates a combined meaning. Derrida's account of their exchanges gives the impression that they had some repartee about whether questioning and praying were different or ultimately identifiable. But to say that questioning and praying can be identified with a hyphen is ontology. Questioning concerns interpretation, making sense of

\footnotetext{
${ }^{746}$ Levinas Reader, 203.

747 “Acte du dire...le suprême pasivité de l'éxposition à l'autre”. Autrement qu', 81.

${ }^{748}$ Jacques Derrida, Adieu à Emmanuel Levinas, Paris: Editions Galilée, 1997, 17.

${ }^{749}$ Adieu à Emmanuel, 26.

750 "La question de la Question ... se fait demande et prière”. Autrement qu, 45.

751 “nous nous sommes souvent adressé ce que je n'appellerai ni des questions ni des réponses, mais peutêtre, pour me servir d'un autre de ses mots, cette sorte de «question, prière», une question prière dont il dit qu'elle serait encore antérieure au dialogue.Cette question-prière qui me tournait vers lui, elle participait peut-être déjà de cette expérience de l'à-Dieu par laquelle je commençai tout à l'heure.". Adieu à Emmanuel Levinas, 26.
} 
a mystery, sustaining a quest. Praying concerns communication, surrendering to another, giving way to the other horizon of a relationship. They are very similar but prayer involves a radical difference between one and another. The one who prays waits on another for an answer. The answer is radically indeterminable. On the other hand, one who questions bears a certain orientation towards an answer. This was Levinas criticism of Wittgenstein and his belief that every question has an answer; ${ }^{752}$ the question has some say in the answer. Prayer is involved when one has no answer, and is put radically in question.

But when Derrida introduces Levinas' "question, prayer"753 the hyphen is Derrida's invention ${ }^{754}$. But his hyphen in "question-prayer" supresses the difference expressed by the comma in "question, prayer". The issue is how to respond to this disjunction, this rending of the hyphen by an intervening transcendence through which Derrida has been forced to say the word "adieu". Questioning holds on to the problem of the incomprehensible, praying lets it go.

To some extent the questioner sets the terms for the answer. But the one who prays, surrenders unconditionally to whatever response may - or may not - return. Therefore, prayer involves the passivity of the related to in a way that questioning fails to achieve. Prayer involves an expression of powerlessness; in this powerlessness, the meaning of death comes to expression and a gift of surrender is released. But Derrida's hyphen prevents the powerlessness of death and prayer to be liberated from the horizons of the question.

The analytic apparatus introduced at the start of this thesis, concerning the difference between sense-bearers and senses brings clarity to the difference between the two philosophers. For Levinas, saying "adieu" meant expressing the sense that the other has left the world of sensebearers. The other has transcended to the overwhelming horizons of the infinite, a sense beyond sense bearers. Derrida, comes close to saying this, but, by binding prayer to questioning, in the question-prayer, and by binding, to his interiority, the one to whom he says Adieu, he does not agree to the breaking of the bond between the sense and the sensebearer. The relationality of the sense remains bound to the identity of the sense-bearer. This is "ontological". Ontology is the idea that every sense must have a sense bearer.

\footnotetext{
${ }_{752}^{752}$ Levinas, Dieu qui vient à l'idée, 249.

753 Autrement qu, 45.

754 Adieu à Emmanuel Levinas, 26.
} 


\section{Meaning in the Depths of the Impossible}

It is necessary to describe a sense that is distinct from sense-bearers. This is the root phenomenological issue with which this chapter and this thesis is concerned. The discussion explores Levinas" aphorism - "thought thinks more than it thinks" 755 by examining the contributions of Heidegger, Derrida and Levinas.

"Thought thinks more than it thinks" - what can this mean? First, it can mean that thought thinks itself to the core of its existence and finds itself thinking according to things it did not cause. Second, it finds itself moved by the possibility of things it did not cause and encouraged to allow those things to affect it. Third, it is always already affected and overpowered by the infinite that moves it to think in the ways of the other.

The first approach to understanding concerns the way of agency. The agency is not complete but might become more profoundly actualized as it reflects on the things it did not cause. The second approach relates to Derrida's idea of the possibility of impossibility. The agency is not complete and is heading towards increasing expressions of passivity. The third concerns Levinas' idea about the impossibility of possibility. There is no agency, except in a derived way. Rather, the thought is formed according to an infinite obsession with another. A passivity for the other which makes of the self, from the first, an offering for, and with the other.

These three approaches can be applied to a traditional sign such as the Eucharist. The first concerns a thought which would identify the Eucharist; it is an actual possibility to produce the Eucharist, albeit by faith, and then celebrate it. The second is thought which accepts that the Eucharist is outside its horizons of possibility, yet acknowledges that it could inspire meaning through the horizons of impossibility. The third, is thought which finds itself always already overwhelmed by the Eucharist. It is the impossibility of its possibility; only the Eucharist creates meaning. The impossibility of the other, death, resurrection and infinite communication is always already the meaning of the Eucharist.

All three approaches are evident in Heideggerian and Post-Heideggerian thought. The early Heidegger had ambitions which are reflected in the first kind of thought. The later Heidegger,

\footnotetext{
${ }^{755}$ Emmanuel Levinas, "Philosophy and the idea of Infinity" in Collected Philosophical Papers, Alphonso Lingis (Trans.), (Dordrecht: Martinus Nijhoff Publishers, 1987), p. 54.
} 
and even more so Derrida, thought the inevitable impossibility that arises among possibilities. Levinas was unique in articulating the sense of an impossibility of possibility, an impossibility that binds subjectivity to the insuperable passivity that impossibility imposes. The second and third of these ways of thinking will explored in the next paragraphs.

\section{Of Time and Passivity for the Other}

Levinas reflected on Heidegger's most revolutionary description of time as - "being-towardsdeath" and "being-towards-end", but his philosophy of time differed from Heidegger's. Concerning his own sense of subjectivity he wrote - "This search for death within the perspective of time... does not signify a philosophy of Sein zum Tode" ${ }^{\text {"756 }}$. Levinas discerned the contrary to be the case - "death is the patience of time" Totality and Infinity: “Ce n'est pas la finitude de l'être qui fait l'essence de temps, comme le pense Heidegger, mais son infini." ${ }^{758}$ In this text he speaks of "the infinity of Being",759 that produces "the essence of time"760. After Derrida's "Violence and Metaphysics", Levinas banished this ontological language and spoke of an "infinite diachrony",761, rather than "the infinity of Being”. Nevertheless, in both his ontological and post-ontological language, the passivity and the infinite were fused together.

While Heidegger and Derrida expounded on "the possibility of impossibility ${ }^{762}$ ", Levinas articulated the contrary - "the impossibility of all possibility" "763. The key to this distinction turns on the difference between a finite and an infinite passivity. A finite passivity allows for a certain orientation towards possibilities, even if that orientation and those possibilities must come to an end. But the weight of an infinite passivity prevents even the orientation towards possibilities. It immediately imposes "the impossibility of escape from God". 764 In "Otherwise Than Being or Beyond Essence", Levinas speaks of an "absolute passivity" and writes that "this is not only the possibility of death in being; the possibility of impossibility; but an impossibility which is anterior to this possibility, the impossibility of evasion, absolute

\footnotetext{
${ }^{756}$ Emmanuel Levinas. God, Death, and Time. Translated by Bettina Bergo. Stanford: Stanford University Press, 2000, 8.

${ }^{757}$ Emmanuel, Levinas. Totalité et infini: Essai sur l'extériorité. Paris: Kluwer Academic, 1990, 8.

${ }^{758}$ Totalité et infini, 317.

759 Totalité et infini, 317.

${ }^{760}$ Totalité et infini, 317.

${ }^{761}$ Levinas, Autrement qu', 20.

762 Derrida, Aporias, 78.

${ }^{763}$ Levinas, Autrement qu', 204.

${ }^{764}$ Levinas, Autrement Qu' être, 204.
} 
susceptibility, gravity without any frivolity, birth of a meaning in the obtuseness of being, of an "ability to die [pouvoir mourir]", submitted to sacrifice.",765

This account of changes in his language, from Totality and Infinity to Otherwise Than Being or Beyond Essence justifies saying that, despite his earlier ontological language, Levinas always thought against ontology. Furthermore, the analysis of Thomas Aquinas' late trinitarian thought in Chapter 3 showed that ontological thought and language is not adequately equipped to deal with issues of passivity and relationship. It is the restricted to act and identity. Thanks to Derrida's exposition, in Writing and Difference ${ }^{766}$, of inadequacies ${ }^{767}$ in Levinas' language in Totality and Infinity, Levinas recognised the need to articulate a new genus through which philosophical discourse can be sustained. Taking up Plato's reference, in "The Republic", to "the Good beyond essence"768, he argued that "a genus opposed to being"769 has been needed since antiquity. "Otherwise than Being or Beyond Essence" established that genus. To understand the meaning of "a genus opposed to being" is to understand why Levinas would charge Heidegger and Derrida with writing ontological philosophy. With Heidegger, the matter is clear; he was the philosopher who "thinks one thought" - 'Being,770. However, with Derrida, he was not always thinking ontologically and he prioritized the other. But, further reflection on differences between Derrida and Levinas show that Derrida had not based his thought purely in relationship. Where Levinas states, absolutely, the impossibility of escaping relationship, Derrida articulates the possibility of escaping relationship, at least for a time - at least until impossibility arrives. Therefore, Derrida's thought is not based absolutely, in being related to. The articulation of an inescapable sense of being related to from beyond the horizons of Being, in "substitution", in “the other's approach to me" - was Levinas' supreme achievement.

\section{The Beginnings of Fire}

Their difference can be clarified more. Again, a comparison with Derrida brings into relief the sense of passivity in Levinas.

\footnotetext{
${ }^{765}$ Levinas. Autrement Qu' $\underline{\text { être, }}, 204$

766 Jacques Derrida, "Violence and Metaphysics" in Writing and Difference, translated by Alan Bass, Chicago: The University of Chicago Press, 79-153.

767 "The Greek thought of Being forever has protected itself against every absolutely surprising convocation." Writing and Difference, 153.

${ }^{768}$ Plato, Republic Book 7 quoted in Levinas, Autrement Qu' etre, 13

${ }^{769}$ Levinas. Autrement Qu' $\underline{\text { être, }}, 13$.

${ }^{770}$ Heidegger, Martin “Nur noch kann ein Gott uns retten.” Der Spiegel 30 (May 1976): 193-219.
} 
First, by way of Derrida, some thought may be given to "the possibility of impossibility". It is a superb accomplishment. Where time is finite, the meaning of thought, reaching out to the infinite, responds to the unfinishable possibilities of Being. In the environment of the finite, "the infinitely finished finite" 771 , Derrida found a way to renew meaning incessantly. He used the prefix "re-" to articulate ways of sustaining a sense of meaning beyond the negated-step "le pas" (the step/not beyond) $)^{772}$. "Le pas" is never the end of all steps. There is always the possibility of stepping again, the possibility of reference, return, remembrance, re-interpreting (re-lire). Beginning De l'ésprit ${ }^{773}$ he wrote, "je parlerai du revenant",774. "Re-" brings the element of return and even going back. This is a given in the performance of meaning that finitude cannot prevent. ${ }^{775,}$ Along with these possibilities of renewal, particularly during the writing of De l'ésprit, Derrida also gave increasing attention to the prefix "à-" "towards". This brought with it the sense of relationship. He concluded "Apories" by considering the prospect of an "arrivant" 776 and developed a relational sense of the future. To think the development of Derrida's thought it may be said that with the "arrivant" the step ("pas") of openness for the future is invincibly opened. It is always necessary to be unconditionally open for "l'arrivant ${ }^{777}$.

In all these texts, there is the hope of a good which awakens subjectivity to meaning. It may be referred to as a 'hope', it is not present. The present does not provide the basis for that hope. The present is mortal, it is a sense-bearer that lacks the ability to determine the future. In this thesis possibility refers to a sense supported by a sense-bearer, while impossibility is a sense that is not supported by a sense-bearer. When this distinction is applied to Derrida's consideration of the arrivant, the arrivant brings alteration. When all the possibilities of temporal existence are at the limit, there remains the sense of one who arises from outside those possibilities. The impossible brings an end to the possible but impossibility signifies. Therefore, meanings may be discerned in the depths of the impossible. In terms of the possibilities of Being there is an end, but the arrivant may arrive from outside those possibilities. The thought about the arrivant concerns a sense that arrives as an immediate

\footnotetext{
${ }^{771}$ Jacque, Derrida. Aporias: Dying - Awaiting (One Another at) the “Limits of Truth". Translated by Thomas Dutoit. Stanford, CA: Stanford University Press, 1993, 81.

${ }^{772}$ On Derrida and "le pas" see Herman Rapaport, Heidegger and Derrida: Reflections on Time and Language, London: University of Nebraska Press, 130.

773 Jacques Derrida, De l'ésprit: Heidegger et la question. Paris: Galilée, 1987.

${ }^{774}$ De l'ésprit, 1.

775 Dying awaiting (one another at) the "limits of truth". Aporias, title page.

${ }^{776}$ Derrida. Aporias: Dying-Awaiting, 33.

${ }^{777}$ Derrida. Aporias: Dying-Awaiting, 33.
} 
sense, a sense without a sense bearer. It deconstructs the meaning of the sense bearer. Sets it on fire. Fire is the destruction in deconstruction that occurs when an impossible sense touches a sense bearer. Being cannot determine that the impossible will signify but the limits of Being provide a "threshold" for the arrivant to cross with its flame, should the arrivant arrive. The sense-bearer can go no further but the sense of meaning may still arrive, and the desire for meaning may still reach out, beyond the destructive moment of the impossible. This sense arrives from outside the horizons of sense bearer, it transforms the dynamics of the sensebearer.

This transformation is sacrificial. It is hospitality, a sacrifice for the other. In "A Word of Welcome" $(1997)^{778}$, his first work on Levinas after his friend's death. Derrida explored the language of "hospitality" in "Totality and Infinity". He indicated and explored a transition from "host" term which dominates "Otherwise Than Being or Beyond Essence". This language of hospitality-sacrifice has obvious correspondences with the Eucharist. Not so much because the bread consecrated at the liturgy is generally referred to as "the host", but, because the Eucharist is the liturgical expression of hospitality.

Derrida's devotion to hospitality shows why he and Levinas were such good friends. Furthermore, there were profound similarities in their thought. This is evident in ways that the sense of the "arrivant" figures in Derrida's thought. The expression "arrivant" was not used in "Of Spirit" (1987), but in a later interview Derrida commented on the significance of the arrivant in that text. David L Clarke's recounts Derrida's reflection on his awakening to l'arrivant. "While writing the brief tableau vivant, he [Derrida] remembers giving the arrivant an opportunity to come and be heard". Then using Derrida's own words Clark recounts that this arriving and hearing left Derrida "actively perplexed". His being "actively perplexed" had continued through the subsequent years ${ }^{782}$. Can an ongoing "active perplexity" through the influence of the arrivant, be anything but an expression of relational passivity. It is not the same as Levinas' sense of absolute relational passivity. Derrida "gave

\footnotetext{
${ }^{778}$ Derrida. Adieu à Emmanuel Levinas

779 Jacques Derrida, A Word of Welcome, 42.

${ }^{780}$ A Word of Welcome, 55.

${ }^{781}$ David L, Clarke. "Bereft: Derrida's Memory and the Spirit of Friendship." In "Late Derrida," edited by Ian Balfour, special issue, South Atlantic Quarterly 106, no. 2 (Spring 2007): 291- 324, 293.

${ }^{782}$ Derrida, Jacques and Didier Eribon. "Heidegger, the Philosopher's Hell.” Translated by Peggy Kamuf. In Points Interviews 1974-1994, edited by Elisabeth Weber. 181-190. Stanford, CA: Stanford University Press, 1997. Interview originally published in La Neuvel Observateur, 6-12 November 1987, 171-172, 183.
} 
the arrivant an opportunity to come and be heard" ${ }^{783}$ Nevertheless it is a statement of great significance. "Perplexity" becomes the title of the work $^{784}$ in which, 9 years later, the name "l'arrivant" is first written (1996). The title of the work "Apories" has powerful bonds with Heidegger. It recalls the quote from Plato, with which Heidegger introduced "Being and Time", "we have become perplexed"785. But surely most significantly it recalls Derrida's encounter with l"arrivant". What was the "arrivant" in Of Spirit? "I will speak of ghost, of fire and of ashes" announced Derrida. This was the perplexity in a text full of hope. Every syllable of the text concerned the devastating fact of fire and ashes which still spread from fascism. The sense of "fire" that pervades $O f$ Spirit speaks of this overwhelming arrival ${ }^{786}$.

With a similar, though unique passion, Levinas, also "dedicated" "Otherwise Than Being or Beyond Essence" to the "victims of the same hate for the other man"787. This suffering, overwhelmed by the suffering of the other, is the Levinasian idea of infinite passivity for the other. According to Levinas, the infinite has always already arrived. Subjectivity is always already formed in relation to the infinitely given other. The challenging expression that Levinas uses to articulate this way of being passively formed for a relationship is "election" 788 . With Derrida, there is giving an opportunity to the arrivant and perhaps a hope that l'arrivant may chose the subject. With Levinas, prior to hope, the Good has chosen the subject to be a hostage for the other ${ }^{789}$. "The Good loves me before I have loved it"790. The infinite passivity of time is therefore an infinite of choice. Not the choice of subjectivity but the choice of the Good.

To sum up: Derrida, proposes the sense of an "arrivant". If $s /$ he arrives, $s /$ he does not on her/his own basis, from outside the possibilities of the host. But the arrival may not transpire and may not be accepted. ${ }^{791}$ This is not the case with Levinas, the absolute insuperability of infinite passivity involves a different kind of relationship. The infinite has always already arrived, has already crossed the threshold by way of "the other in me"792. The infinite is not a possibility, not even an absolutely influential possibility. It is the invincible passive dynamic

\footnotetext{
783 "Late Derrida," 293.

784 “Apories" (1996)

${ }^{785}$ Martin, Heidegger. Sein und Zeit. Tübingen: Max Niemeyer Verlag, 2006, 1.

${ }^{786}$ Points... Interviews 1974-1994, 181-90.

${ }^{787}$ Autrement qu', Dedication page.

${ }^{788}$ Autrement qu', 31.

${ }^{789}$ Autrement qu', 32.

${ }^{790}$ Autrement qu', 25.

791 "Late Derrida," 293.

792 Autrement qu', 198.
} 
of the one, always already chosen for the other. But how does the Good signify passively? The relational sense of passivity involves the difference between a relator and a related to.

\section{Of Suffering and Traditioning}

An inescapable issue, when discussing contemporary European thought is the problem of traditional victimization. Derrida and Levinas, who were both Jews, encountered the most forceful traditions of victimization. Their experience is reflected in their literature. For Derrida, the sense of "l'arrivant", was filled with grief for the suffering and violent deaths of the victims in the death camps. Levinas, was even more intimately exposed to the "Passion"793 of his people. He described what became of him through the agony of his people, "absolute susceptibility, gravity without any frivolity". A text dedicated to his deceased parents and family members, "Otherwise than Being or Beyond Essence" rings out as the meaning of his life. It is a work of covenantal memory, " $z k r$ "794. It articulates his identity altered by the suffering of the other. Like "Totality and Infinity", it articulates "the impossibility of all possibility", the "'ability to die', submitted to sacrifice."795 Derrida, a younger man from Algeria, encountered the crisis differently, but the intensity and depth of the encounter emerged through his sense of the "arrivant". After writing De l'ésprit Derrida confessed that "l'arrivant", informed the margins of this book, filled with grief for the suffering and violent deaths of the victims in the death camps. (cf above).

In a text, by a non-Jew, on the Eucharist, it is impossible to unsay the horrifying era. But it is also necessary to respond to the abiding problem: the preference for my peace and security over another's suffering and vulnerability. Yet, there is no path beyond suffering except to journey with those suffering. Even for a kiwi, many decades later, without relatives involved in the devastation, the crisis continues. The crisis is felt within traditions themselves. In Europe, during Hitler's regime, Catholics were divided among themselves, as were Protestants. There were different perspectives. How can this be? How can the choice for alienation from the suffering be taught as the way of the Eucharist? How can it be taught as the way for humanity? How can these matters be so unclear? Through reflecting on the crises of traditions and through reflecting on the Eucharist, it is always necessary to strengthen the relational work of traditioning and the Eucharist. This may address some of the problems of

\footnotetext{
${ }_{793}^{793}$ Emmanuel, Levinas. L'au delà du verset. Paris: Éditions de Minuit, 1982, 17.

${ }^{794}$ Levinas. Autrement Qu' être, Dedication page.

${ }^{795}$ Levinas. Autrement Qu' $\underline{\text { etre }}, 204$.
} 
marginalization that have emerged through history, outside as well as inside the traditions of the Eucharist. Prejudice is practiced in environments that claim to be free of prejudice. It is a particular definition of social environments that arises through the kinds of tradition that are practiced. It is an intrinsic problem of traditioning.

In this thesis, it is being argued that there is an identifying of tradition and a disengaging of tradition from traditioning that pervades the history of the Eucharist. It pervades the history of philosophy and all kinds of traditioning, not least the traditions of habitually unreflective politics. The argument in this chapter is that the misunderstanding of traditioning is produced by the loss of the sense of relationship. The task for this thesis has been to establish the necessity and veracity of a relational sense of the Eucharist (Ch 3) and to establish that the vitality and worth of traditions is not in their identities but in their relationality (Ch 4). It is time to articulate what is meant by "the relational sense of traditioning". This is not an easy task. The purpose of the following, final, section of this chapter is to discern how obstacles to relational traditioning may be countered, and to articulate a sense of traditioning that overcomes those obstacles and serves the unconditional gift of relationship.

\section{Part B: Traditioning}

\section{Relational Passivity and Social Agency}

This thesis has been written to explore the dynamic interconnections between hetero-affective subjectivity and traditional expressions of social life. It has sustained reflections on the interconnections between agency and passivity. Following Levinas the thesis has explored the need to develop ways of traditioning that arise out of the subjective passivity of the one for the other. It has found a way forward in Levinas' phenomenological reduction.

Phenomenological reduction is the practice of articulating the sense of the immediacy of the given. But the immediate given is the passivity of temporal existence, the inescapable fact of being related to before having chosen my own existence. Throughout the thesis the Eucharist has been explored as a sign that sustains this nurtured passivity. It provides the immediate relational nourishment of food. Like the food that a mother gives to the child she is bearing, it communicates before it is recognized and it communicates in a way that gives both the food and the one who gives the food. This nourishing relationality is infinite and unconditional 
passivity, like the Mother of Jesus, at the foot of the $\operatorname{cross}^{796}$, bringing the nourishment of relationship to her newly-given son, supporting him as he supports her in the inescapable gifts of relationship. Furthermore, this relational nourishment arrives, not only for individuals but in socially formed ways. However, this point of the argument needs to be established. The cementing element that binds subjectivity to society and society to subjectivity has still not been articulated. However, it has been broached and some ways forward have been indicated. Now there is more to be discovered. The remainder of this chapter, and some reflections in the Conclusion of the thesis are written to distil the relational elements that structure its progress.

In describing the solidarity between subjectivity and society, a first point to note is that, subjectively and socially, agency relies on passivity. This has been demonstrated through reflections on Levinas and Thomas Aquinas. Relational agency is inspired by the infinite passivity of having been related to before I can chose to relate.

However, it is still necessary to say something of how choosing to relate arises out of being related to. This amounts to giving a Levinasian account of agency (a task which is done most simply by adhering to Levinas' practice of using the pronoun for the first- person singular). Levinas accounts for being, justice and historical sociality through the arrival of a "third" into the relationship. The third is the other's other. Through the third I am not simply one who is infinitely responsible, for the other. Rather, I am charged with "responsibility for the responsibility of the other" ${ }^{\prime 797}$. Therefore, with the arrival of the third, responsibility for the responsibility of the other becomes responsibility, with the other, for the third. Not only that responsibility also turns, with the third towards the other, with the third and the other towards me. In this way, I am involved in the sociality of justice, agency for the others in the coequal presence of beings. But Levinas does not describe the transition easily. The way it happens needs to be exposed. Something which Levinas never undertook. The following is an argument, based in Levinas, that sketches the transition from the subjectivity of the one-forthe-other, to responsibility for the other and the third in the processes of traditioning.

Beginning from the phenomenological reduction of the subject it is able to be asserted that subjectivity is irreducibly passive from the outset. It has always already been related to before it is able to actualize relationship in return. The sense of being related to is awoken through the approach of the other. The other approaches as one for whom I am infinitely responsible,

\footnotetext{
${ }^{796}$ John 19:27

${ }^{797}$ Autrement que, 186
} 
a visitor sent by God, in whom God also visits. Levinas has called this sense of an infinite difference in the other, a difference which summons the self for the other, and summons the other and the self for the third, "illeity ${ }^{798 "}$ Illeity indicates a way of concerning me without entering into conjunction with me. ${ }^{799}$ It may be described as "the he in the depth of you" 800 Thereby it keeps the sense of responsibility infinite and sustains the sense of openness that welcomes the third into the expression of the relationship of the one-for-the-other. It seems to this author that two changes occur through the arrival of the third. Firstly, it reveals the depth of responsibility for the other. The third appears with the other, as the other's responsibility. Therefore, my responsibility for the other includes the other's other, the third. Secondly, the arrival of the other's other produces a new horizon, in and through the sociality of the other. This emerges as a horizon in which the goodness of relationship speaks in a new way. I am moved or called on to value the relationship between the other and the third. This horizon is referred to in this thesis as "traditioning". It relies on substitution.

Traditioning extends substitution from the other to the third. If the other is my other's other, and I am responsible for the responsibility of the other then I am one-for the-other-one-forthe-other. ${ }^{801}$ To put this another way, I live for the love between my neighbours. Between the other and the third, subjectivity discerns the way of peace, "peace to those who are near and those who are far away ${ }^{802}$. Peace between the others, peace in the relationality of peace, which is also the way of peace in the self. Therefore, the self is in the world of the relator and the related to, the world of identities, which sustains the synthesis of the relator and the related to.

Symbols arise in this world of reflective relationality. They express the shared world of relationship. Practicalities develop involving the motives and responsibilities of the first, second and third persons. The world of sociality and action has arrived. The ethos, philosophies, arts, sciences and technologies of traditioning are underway.

In this world, it is possible to forget the infinite passivity of relationship. But that relationship is the basis of ethics and being. If the infinite passivity of relationship is allowed to signify, then relationships between the identities in the world are able to support one another in the ways of inspired passivity and relational agency. The task for traditions is to sustain the sense

\footnotetext{
${ }^{798}$ Autrement qu', 27.

799 Autrement qu', 28.

800 "God and Philosophy", 178.

801 This syntax is intentional.

${ }^{802}$ Is $57: 19$.
} 
of relationship, not as a social enterprise, but as a gift through which the infinite loveableness of the other, of the other's other and of the one for the other(s) becomes a sustained thanksgiving. The remainder of this chapter concerns building a case for valuing the passive syntheses that are formed through the temporality of traditions.

\section{The Traditioning of the Beloved}

"I only love fully if the other loves me, not because I need the recognition of the Other but because my pleasure rejoices from her pleasure and because, in this unparalleled convergence of identification, in this tran-substantiation [italics Levinas] the Same and the Other do not become confused, for precisely - beyond every possible project - beyond every power of feeling and intellect, the child is conceived" ${ }^{\prime 803}$

In this text of 1961 Levinas articulated the supreme sense of traditioning and the impossible "beyond every possible project" - the child is conceived. S/he belongs with "the Same and the Other" saving them from confusion. But history suggests that this concurrence of philosophy and the traditional defined family could not have been written after the sixties. This point exposes the problem which this chapter, this thesis and traditioning itself is moved to address. The relationality of the child, the first expression of the passivity of infinite loveableness, has been lost to the world of business and of intellectual discourse, perhaps even to education. But loveableness is the only hope for traditioning. Derrida, allowed for the gift of relationship, allowed the arrivant to come but he had not imparted a tradition. It would seem there can be no tradition for the unexpected. However, in 1961, Levinas, in his description of the family, had described a traditional gift of the unexpected "- beyond all possible projects beyond every power of feeling and intellect" ${ }^{\prime 804}$. Beyond every active synthesis comes the begetting of a child, a gift of passivity, the fruit of a prior communion. Now in an increasingly technologized world, where the active synthesis holds out all kinds of possibilities how can the passive synthesis be allowed to signify? How does the passive sense of being valued relationally, survive in a world that treats agency as though it is the basis of values?

A dramatic change in global traditioning had transpired between the time Levinas wrote "Totality and Infinity" and "Otherwise Than Being or Beyond Essence". To address this

\footnotetext{
${ }^{803}$ Levinas, Totalité et Infini, 298.

${ }^{804}$ Totalité et infini 298.
} 
crisis Levinas retained the relational priority of the familial environment that he celebrated in 1961. Therefore, in 1974 he described the one-for-the-other, ("substitution") and the third. Erotic pleasure ("volupté" "tran-substantation"), an ethical gift bound to fecundity, was rethought according to the ethos of substitution. The relational sense of subjectivity was intensified through "obsession" showed the need to radically rethink subjectivity and the subjective character of sociality.

Most importantly, through this time of dramatic change, Levinas sustained and strengthened his reflection on the passivity of the-one-for-the-other. Therefore, he offered hope for a description of traditioning, and a way to tradition the impossible. Initially the task may look forbidding, but the inescapable imposition of relational passivity, substitution or expiation the nexus that binds the one, the other and the third - is the heart of traditioning. It offers the hope for a way back into a radically relational rather than technologically proposed sociality.

To grasp the topic of sociality in Levinas, it is necessary to see that it concerns the sense of the infinite. "It is thanks to God alone that, incomparably subject to the other, I am alongside another among others... The reciprocal correlation re-attaches me to the other person in the trace of transcendence, in l'illéité. The passage of God....... is precisely the return of the incomparable subject into a member of society"

About the same time that Levinas was describing this sense of infinite passivity of the one for the other, and its connections to sociality, "thanks to God" through the third, De La Potterie published his two volume "Verité dans St Jean". Early in Vol 2 he described the difference between two kinds of work, the Gospel and the Epistles ${ }^{807}$. The former concerned the disciples' intimate relationship with Jesus; the Epistles concerned the disciples' relationship with one another. In terms of the above analyses, it may be said that the former concerned the infinite passivity of the one for the other while the latter concerned the life of relational agency in the sociality that passivity inspires. This transition through passivity to agency is expressed in Jesus' words about himself and his relationality with the Father: "this is why the Father loves me, because I lay down my life in order to take it up again. I have power to lay it down and I have power to take it up again. This command I have received from the

\footnotetext{
${ }^{805}$ Autrement qu', 137-42.

${ }^{806}$ Autrement qu, 247.

${ }^{807}$ Ignace de la Potterie, La vérité dans saint Jean, 2 vols, Rome: Editrice Pontificio Istituto Biblico, 1999, 528
} 
Father." 808 That Jesus took his life up again provided the new "beginning" and commandment through which the Epistles describe the community's new life of traditioning ${ }^{809}$.

It is also instructive to look at the relationship between the Beloved Disciple and Jesus, and then to consider how the Beloved Disciple transitions - "grâce à Dieu" - from the foot of the cross to the community at large. The words of Jesus from the Cross to his mother and the Beloved Disciple ${ }^{810}$ offer profound insights into the practice of traditioning. It is an exceptionally significant moment in the structure of the Gospel. It forms the well-known inclusion with the miracle of Cana and is at the high point of the Gospel - Jesus' last words and saving ministry to his disciples. The Beloved Disciple, overwhelmed by the infinite suffering of the Cross, is moved into relational agency, for the Mother of Jesus. This is hospitality, not based in the actualization of an ego, but in the infinite patience of the one for the other. It is only ontology that allows passivity and agency to be mutually exclusive. In the ethics of relationship, passivity and agency are indispensable to each other. Relationality is expressed in the bond of the relator and the related to.

The Beloved Disciple has been at the side of Jesus at the Supper and witnessed the intimate depths of Jesus with the Father. He has also learned from the ways of Jesus towards him, learning to dwell with Jesus as beloved in lover, ${ }^{811}$ in the depths of his infinite loveableness. Now the Beloved Disciple is about to receive the gift of intimate communication, as son to mother with the "Mother of Jesus".

To grasp the depth of this text it is helpful to explore again the use of the word "i $\delta$ io $\varsigma$ ". ("to

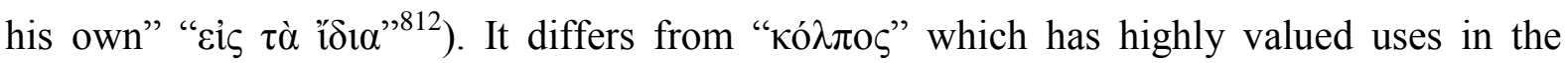

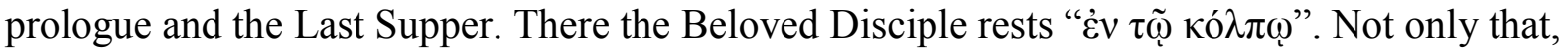
he imitates Jesus' own way of dwelling in the heart of the Father. It is hard to imagine a more intimate expression. Perhaps it is the most intimate expression in the Gospel. But the use of ' $\delta 1 \alpha$ also has claims to the title of greatest intimacy. In Deuteronomy 13:6, I the Septuagint, when Moses speaks against idolatry, he tells his listeners, "if any one entices you [to idolatry]... do not go with them." He goes through a list of who "any one" might mean, proceeding through the list of companions according to increasing degrees of intimacy. The second to last of these is "the wife of your bosom", "кó $\lambda \pi \circ \varsigma$ " but the last is, "your most

\footnotetext{
808 Jn 10:17-8.

8091 Jn 1:1-4.

810 Jn 19:26-27.

811 Jn 13:23.

812 Jn 19:27.
} 
intimate friend who is your own", "if $\delta$ los". These thoughts express the sense of the other-self at the basis of traditioning. The other self is the first party in the way of substitution. A child is the other self to its parents. It is incapable of reflecting on itself and valuing his or her self autonomously. The child values itself through its self-expression in the environment of its parents. It goes through the long process of learning to be another self. This may also be the sense of "tran-substantiation" that Levinas uses in Totality and Infinity. ${ }^{813}$

\section{Accepting the Other-self}

The dynamics of the passive-synthesis and the passivity of traditioning become evident in the other-self relationship. When Levinas chose an epigraph for the core chapter of Otherwise Than Being or beyond Essence - one of the two epigraph's in the book - , he chose a verse from Paul Celan. "Ich bin Du wenn Ich Ich bin" ${ }^{\prime 14}$.

The verse and Levinas' quote throws wide open the plight of the disenfranchised. The child who is another self to her or his parents can only say the word "who am I [in the world] if I am not you"? Celan's relationship with Heidegger also reflects the passions of the other self.

In spite of Heidegger's associations with facism, Celan considered Heidegger Europe's greatest philosopher. Heidegger, in turn, considered Celan Europe's greatest poet. Eventually they met and although the received wisdom is that Celan was very disappointed with his meeting with Heidegger, James $\mathrm{K}$ Lyon ${ }^{815}$ has given a very convincing account of their exchanges; makes it clear that they enjoyed each other's company.

It seems certain that Heidegger had clearly told Celan of his regret for his association with fascism and Lyon's shows that Celan was expecting Heidegger to render public, the apology he had made to him in private; for all who had suffered from his involvement with fascism. ${ }^{816}$ After their most significant meeting, Celan sent a poem ("Todtnauberg") to Heidegger expressing this expectation and recounting the occasion ${ }^{817}$. Of all Celan's poems this is the only poem that is not directed to the second person. It is in the third person. It recalls their day together and refers to his entry into Heidegger's guestbook. He wrote in the book, of "a

\footnotetext{
${ }^{813}$ Totalité et infini, 298.

${ }^{814}$ Autrement $q u^{\prime}, 156$.

${ }^{815}$ James K Lyon, Paul Celan and Martin Heidegger: An Unresolved Conversation, 1951 - 70, Baltimore: John Hopkins University Press, 2009

${ }^{816}$ Paul Celan and Martin Heidegger, 187- 9.

${ }^{817}$ Paul Celan and Martin Heidegger, 175-177.
} 
hope, today for a thinker's coming word in the heart," 818 ("einer Hoffnung, heute, auf eines Denkenden kommendes Wort im Herzen") ${ }^{819}$. This is the language of the other self. Whose heart was Celan hoping the word would come to? Heidegger also wrote to Celan about this meeting: "the poet's word, that is at the same time encouragement and admonition, preserves the memory of a day of various moods in the Black Forest, I think that someday some of it will be redeemed from unspokenness through conversation. ${ }^{820}$

In terms of this Essay the poem epitomises the work of traditioning. It is not from an I to a Thou. It is with another self but it concerns the relationship of those selves to another and to others. Therefore, the poem, in the third person remains relational. It concerns the voice of a "we" speaking to the world. But this "we", between Celan and Heidegger, never formed properly. It is only thanks to Lyon's book that something of it can be spoken to the world, beyond their "conversation".

The crux of Celan's hoped for traditioning involves the willingness of an absolutely relational heart. Relational truth is greater than the truth of discovery. Levinas quotes Augustine's concern that he loves the truth when he can share it without cost. But when the truth demands that he suffer a reproach, he avoids the truth. ${ }^{821}$ There seems to be something of this in the difference between Heidegger's and Celan's approaches to healing in the relationships between the Jews and the Germans. Heidegger could have made a public statement. But this would have involved the public acceptance of a reproach and the remembrance of something he, and the people of Germany, would have preferred to forget. The situation has faint resemblances to the post-resurrection encounter between Peter and Jesus. "Peter, was hurt when Jesus asked him a third time 'do you love me'."822 Yet, as Celan also attempted, Jesus helped Peter work through his hurt, so that the wound of denial could become a wound of love (albeit grievous). Or, to be clearer, that the wound of a love denied could become the gift of a love affirmed. Then the other (and the self as another other - another self) could learn to dwell in the house of language as beloved in lover.

\footnotetext{
${ }^{818}$ Lyon, Paul Celan and Martin Heidegger, 176

${ }^{819}$ Lyon, Paul Celan and Martin Heidegger, 177

${ }^{820}$ Paul Celan and Martin Heidegger, 189.

${ }^{821}$ Dieu qui vient, 255.

${ }^{822}$ Jn 21:17.
} 


\section{Hospitality}

The sense of the self as gift of hospitality, performs the redemption of traditioning. Through the above analyses of John's Gospel, the gift of the hospitable self figures as a source of Eucharistic traditioning. But this is not the hospitality of one who maintains his own sense of comfort in the practice of hospitality. The hospitality of Jesus was not based in his sense of comfort. He came "to his own" who "did not receive him," 823 But from the vulnerable hospitality of Jesus, the Beloved Disciple learned and taught to tradition hospitality through the Eucharist. The shepherds were struck and the sheep were scattered, each going to their own $^{824}$. But the Beloved Disciple was not scattered. He was with Jesus, the Mother of Jesus and a few other disciples at the foot of the cross. The impossibility of departing, even at the point of death, has led to the gift of a new dwelling, hospitality, gift of the one-for-the-other who also suffers for the others.

After the suffering comes the witness of Mary Magdalene. She meets the Lord, "do not cling to me I have not yet ascended to my Father and your Father, my God and your God." ${ }^{\text {}} 25$ The impossibility of holding on, in the moment of her "adieu" moved her also to relationship with the third. "Mary went and announced to the Disciple's I have seen the Lord". As it becomes impossible to bind the sense of the other to the identity of the self, the self may enter deeper into the gift of relationality through and for the other. .

These thoughts express the sense of the other-self at the basis of traditioning. The other self who, before all else is the other, who lives in the self as beloved in lover (substitution, the infinite loveableness of the beloved) is revealed and given by alterity. A child is the other self to its parents. It goes through the long process of learning to be another self among other selves, one-for the-other-one-for-the-other.

\section{Thomas Aquinas and Emmanuel Levinas, union in the passive synthesis.}

When Thomas Aquinas, near the end of his life, deepened his doctrine of the loveableness of the beloved in the Trinity, and emphasized the significance of the terminus a quo in the Eucharist, he was affirming the passive synthesis. Not the tradition as discerned according to goals of action. But the tradition of a finite relational agency, arising out of, and deepening,

\footnotetext{
${ }^{823}$ Jn 1:11..

${ }^{824}$ Jn 16:32.

${ }^{825}$ John 20:17.
} 
an irrecusable passivity as beloved for the beloved, inescapable passivity of the agent for the beloved.

Levinas is the first philosopher in history to explicate the passive depths of relational life. Of his book Otherwise than Being or Beyond Essence he wrote, "the act 'of saying' will have been, from the beginning, introduced here as the supreme passivity of exposition to the other, which is precisely, responsibility for the free initiatives of the other." ${ }^{826}$ This great insight into the self as passive gift for the free relationality of the other articulates a sense of the unfinishable gift of love in the relational passivity of the self. This gift is always already given for the other; always already given in the inexhaustible openness of an infinite beginning.

In Adoro Te Devote ${ }^{827}$ Thomas Aquinas demonstrated the same dynamic of passivity through the act of saying. The hymn begins "I praise you hiding truth" ("te devote laudo, latens veritas" $)^{828}$. Therefore the opening two lines refer to the agency of praise and worship. But from that moment on Thomas is absolutely overwhelmed by the relationality of the truth. It is not identifiable. Its relationality flourishes because its identity is in hiding. Therefore the intentional act of praise is unable to reach its end. But his heart remains open to the "truly hiding" (vere latitas) "truth" (latens veritas) that he seeks. Therefore, unintentional passivity to hiddenness arises out of the acts of praise for the revealed truth. In the Sacrament of the Eucharist, he is overwhelmed by the astonishing sense of being exposed to such hidden yet immense love. In the relational passivity effected through the hiddenness of love Thomas has become a pure offering of love and loveableness to love and loveableness, "contemplating you my heart faints and fails" ${ }^{\prime \prime 29}$.

The agency of saying is like a doorway. It opens the original act of relationship. But this doorway also opens back onto the passivity of the self, exposing its gift of loveableness; expressing a pre-originary loveableness, a desire which has been inspired by the one to whom the opening words are spoken.

Such passivity, before the sacrament of the Eucharist, is similar to the passivity Levinas articulates before the face of the other, "passivity, without foundation, responsibility for the

\footnotetext{
${ }^{826}$ Autrement qu', 81.

${ }^{827}$ Adoro te devote" in S. Thomae Aquino Opera Omnia, http://www.corpusthomisticum.org.

${ }^{828}$ Adoro te devote.

829 “quia te contemplans totum deficit [cor meum].” Adoro te.
} 
other." ${ }^{830}$ Passivity without a place to stand or to grow from is also expressed by Thomas when he prays, "o memorial of the death of the Lord, grant to me to always live from you ${ }^{831}$." Outside himself, in the passivity of another's death, he desires to live.

The outside is the key to both thinkers, they are lost in expressing themselves in the desire for the other, and so they only become through the relational gift from the other. In this they both exhibit traditioning, which comes to pass through the loss of self-identifying agency, and through the becoming of the one-for-the-other in the hidden passivity of the other's relationality. The benefit of Levinas' phenomenology is that he exposes this relationality through analyses of subjectivity and sociality that were not accessible to Thomas in his day. The benefit of Thomas, is that, to use an expression of Levinas, "he takes" this relationality "to the gentiles" 832 . That could also be described as the passion of this thesis. But not only that, Thomas makes a unique contribution to the sense of passivity in God.

\footnotetext{
${ }^{830}$ Autrement qu' 236.

831 "Presta mihi semper de te vivere." Thomas Aquinas, Adoro te devote" in S. Thomae Aquino Opera Omnia. Corpus Thomisticum,_Compiled by Enrique Alarcón. Pamplona: Universitas Studiorum Navarrensis, 2000-. http://www.corpusthomisticum.org.

${ }^{832}$ Christianity takes "monothéisme aux gentils". Difficile liberté, Quartriéme Edition, Paris:Albin Michel, 1976, 261.
} 


\section{Conclusion}

\section{The Eucharist and the Trinity}

To clarify the understanding of traditioning in relation to the Eucharist and the Trinity in this thesis it would be helpful to look at some applications of "traditioning" (" $\pi \alpha \rho \alpha \delta i \delta \omega \mu$ ") to Jesus, in the New Testament. Unfortunately, in a very summary account it is only possible to note a few of these, but, four uses by Paul mark out a very impressive cosmic trajectory. In Romans 8:32, the Father "handed over [active voice] his Son for us all". In Galatians 2:20, "Christ", with whom Paul is crucified, "handed himself over [middle voice] for" Paul. Then First Corinthians 11:23 recounts "the night the Lord Jesus was handed over" (passive voice) and according to First Corinthians 15:24 "when the end comes Christ will have handed over [active voice] the kingdom of God to him [the Father]".

These texts show that traditioning progresses from the Trinity, through the incarnation, to the crucifixion and the Eucharist, and into the return to the Father at the end of time. Among the immensity of issues this raises, two stand out in relation to this thesis. It is impossible to discuss traditioning without considering agency as well as passivity. But, the first matter to be discussed is holiness. This was the pre-requisite to the mission of Jesus. These two matters, holiness and the interconnections between agency and passivity, will now be taken into treatments of traditioning in the Eucharist and the Trinity.

\section{Relational holiness and the Eucharist}

At the heart of Thomas Aquinas understanding of the Eucharist is "desire". The word "desire" also figures in Levinas treatment of holiness in "God and Philosophy". 833 "Desire" and desirable", along with "love and "loveable," also figure in Levinas' and Thomas' discussions of the $\operatorname{Good}^{834}$. They are intrinsic to accounting for "loveableness" in relation to the traditioning of the Eucharist. The following account of the Eucharist discusses desire and loveableness in order to describe the significance of the Eucharist as a sign of loveableness.

\footnotetext{
833 “God and Philosophy”. The Levinas Reader. ed Sean Hand, 1989, 166-189.

834 Levinas, "God and Philosophy", 173-9. And Thomas, Compendium Theologiae, 1, 45.
} 
With regard to desire in Levinas ${ }^{835}$ and love in Aquinas, ${ }^{836}$ the alteration from agency to passivity, concerns relationality between the desired and the desire, and between the beloved and the lover. Furthermore, in both texts ${ }^{837}$ "the desired" or "beloved", that renders the active passive is the infinite Good ("Bien" "Bonum"). The task now is to reflect on "love" and "desire" outside the works of Levinas and Thomas, in order to examine them in the broader horizons of their traditioning. A text at the heart of their traditioning is the Song of Songs. It also articulates a conversion of love and desire from agency to passivity. Although, to be precise, the Song of Songs portrays a progression from ownership to passivity more than from agency to passivity. However that is to the point of this essay which is concerned with the difference between identity and relationality.

The Song of Songs provides three scriptures which could be called "the I am scriptures of the Song of Songs". In the first, the woman in the Song of Songs declares, "my beloved is mine and I am his" ${ }^{838}$. In the second, after the text shows considerable suffering for her relationship with her beloved, she declares "I am my beloved's and he is mine" ${ }^{839}$. In the third she says, "I am my beloved's and his desire is for me" 840 .

The sequence shows the relational sense of the saying "the first shall be last and the last shall be first" ${ }^{841}$. It concerns the keeping and losing of life ${ }^{842}$. In other words, the woman has lost her life in the desire of the other. In the first of the verses, she was first in the order of relating and last in the order of being related to. In the second of the verses, she was last in the order of relating and first in the order of being related to. In the third she was only in the order of being related to. But in the movement from the act of ownership (the first verse) to the passivity of being related to (the third verse) she does not diminish in her sense of identity. Rather her sense of identity is stronger as she explicitly claims and celebrates her loveableness to her beloved. She also, implicitly expresses his loveableness to her. She does not need to celebrate her identity. She only needs to give it. This is the passivity of affirmed loveableness. Explicitly it is passive, but tacitly, it is profoundly active.

\footnotetext{
${ }^{835}$ God and Philosophy

836 "God and Philosophy"

837 "God and Philosophy" for Levinas and "That God is in himself as Beloved in Lover" for Aquinas.

${ }^{838} \mathrm{Sg} 2: 16$.

${ }^{839} \mathrm{Sg} 6: 3$.

$840 \mathrm{Sg}$ 7:10.

${ }^{841}$ Mt 20:16.

${ }^{842}$ Mt 20:16-18.
} 
The Eucharistic depth of this discussion becomes clear through a reflection on the word "desire" (שפוּקהת). This word occurs three times in the bible. The first time God proclaims one of Eve's curses. "Your desire shall be for your husband and he will lord it over you" ${ }^{843}$ It indicates that her desire lacks liberation and that her relationship with her husband is not from desire to desire but from desire to mind-set. The second reference to desire (שָוּקה more disturbing. It refers to sin's consuming desire for Cain before Cain undertook to kill Abel. ${ }^{844}$ The Lord advises Cain to "rule" over sins' desire. But the Lord has also told Eve that her husband will "rule" over her." In both cases the word for "rule" is "“wָָׁׁ". This correspondence implies that Eve's desire will be regarded, by her husband as evil and he will order it. But the reference in the Song of Songs brings an absolute liberation from these tragic scenarios. It articulates the pure goodness of desire, and of being desired.

In approaching the Eucharist Aquinas taught that the necessary condition for receiving the Eucharist was, "as the Church intended, the desire to receive it". Without desire it is only possible to receive the sign. But with desire, even without receiving the sign, it is possible to receive the Eucharist, the thing signified. ${ }^{845}$ The Eucharist therefore expresses a radical acceptance of desire. This same articulation of acceptance was evident in the Todah psalms and in the sense of the Eucharistic self as "yahid". These were discussed above. ${ }^{846}$

Furthermore, in the Song of Songs, as in Thomas and Levinas, the process of desiring or loving renders the actively beginning desire passive to the infinitely loveable desired. Yet, regardless of the immensity of this alteration, the concrete referent, the identity at the beginning of the process is the same as the identity at the end of the process. This point is at the crux of this thesis since at the end of transubstantiation the accidents of bread and wine remain the same as they were at the beginning. Therefore, "transubstantiation" is the name for a process whereby a finite creature which tends from a finite beginning to a finite ending, is brought instead to an infinite ending. But for the infinite ending to sustain the testimony (or evidence) of the finite beginning, it is necessary for the finite passivity - at the beginning of the process, to be replaced by an infinite passivity. The infinite passivity reveals the sense of the infinite process. To put this another way: because the ending is infinite it comprehends the finite beginning and reforms it according to the attributes of its infinity, (i.e. the finite event becomes an infinite sign, a sign that expresses the infinite).

\footnotetext{
${ }^{843}$ Gn 3:16.

${ }^{844} \mathrm{Gn} 4: 7$

845 "desiderant Eucharistiam, et per consequens recipiunt rem ipsius."

${ }^{846}$ Chapter 1, Part B, section 4.
} 
The change, "more miraculous than any other change", can be more easily understood by using the words "proactive" and "retroactive". The first phase is miraculously proactive, it leads from a finite terminus a quo (bread and wine) to an infinite terminus ad quem (Christ). Immediately, with the arrival of the terminus ad quem, the second retroactive phase is accomplished. It reveals an infinite terminus a quo. The sense of an infinite terminus a quo is necessary otherwise the terminus ad quem would lose its sense as terminus ad quem (a terminus ad quem becomes terminus ad quem relative to a terminus a quo). But if there is no terminus a quo, in relation to which the terminus ad quem signifies, Christ, who is both the beginning and the end, would cease to signify in a temporal way. If the end and the beginning do not signify, (if Christ is neither beginning nor end) the temporality of the Eucharist, which includes the temporal death and resurrection of Christ, will have lost its meaning.

This discussion seems to have suddenly erupted away from the testimony of the infinitely loveable woman of the Song of Songs. But, surprisingly, it concerns the same point: the infinite passivity of the loveable lover to the loveable beloved, the infinite passivity of the origin to the end. Although he is only talking about a change to bread and wine, there seems to be an implicit point - in Thomas' reference to "a change more miraculous than the creation of the world" ${ }^{\prime 87}$ - that the Eucharist involves a radical change at the origins of creation, a change from the identifiable order of ontology to the unidentifiable order of the miraculous. This author also finds here a point Thomas does not make. The ontological order is replaced by relationship. The beginning is changed by the end. The order of relationship not only pervades subjectivity, it also pervades the world. The transubstantiation of non-sentient elements (which are relationally significant as food), shows that the relational turn, the turn to an infinite passivity for the finite, pervades creation.

This authors thesis, ${ }^{848}$.relies on correspondences between Levinas and Thomas about desire being turned from agency to passivity for the other, ${ }^{849}$ This relational turn also responds to statements of the death of "God. "From the Good ("Bien") to me - assignation: relation which "survives" the death of God" 850 . Levinas goes on to describe this relationship of assignation in a way which once again exhibits the way the desirable Good, moves the desiring subject to live for the other. "It is because, in its goodness, the Good declines the desire that it arouses by inclining it towards responsibility for the neighbour, that the Good

\footnotetext{
${ }^{847}$ Summ Theological 3.75,7, arg 3

848 Levinas, "God and Philosophy", 173-9. Thomas, Compendium Theologiae, 1, 45.

849 Levinas, "God and Philosophy", 173-9. Thomas, Compendium Theologiae, 1, 45.

${ }^{850}$ Autrement qu', 196.
} 
preserves the difference ${ }^{851}$ in the non-indifference of the Good which chooses me before I welcome it."

Along with what has been said in other parts of this thesis, there is much more to be said about the consecrated and consecrating relationality that is the Eucharist. However, before concluding this section it is opportune to give a brief sketch regarding the different temporal horizons through which the consecration of the one and the many are brought about. The one, Christ and also the one beloved disciple, are consecrated from the past. Jesus is "one whom the Father has consecrated and sent into the world". ${ }^{852}$ The beloved disciple is consecrated in the bosom of Christ ${ }^{853}$. But the consecration of the many comes about through the sense of the future. Jesus says "for their sake I consecrate myself, that they too may be consecrated in truth." ${ }^{" 854}$ Also, Paul writes, "as often as you eat this bread and drink this cup you proclaim the death of the Lord until he comes" ${ }^{\prime 855}$.

All horizons, past, future and present contribute to the dynamics of consecration. The past one and the future many meet in the present of the Eucharist in such a way that the present of the Eucharist involves contradiction. ${ }^{856}$. Neither the one and the many, nor the past and the future can form an identity in the present of the sacramental celebration. Diachronically these diverse horizons are related. But, synchronically they contradict and this contradiction is the scandal of the death of Jesus. At the Eucharist the death of Jesus is celebrated in the present because it is pure exteriority for the other and openness to his return from the Father. The Eucharist expresses a death for the other, thankful for the gift of relationship. This gratitude must be a gratitude for relationship and not identity, because death is the privation of identity. It is a loss that pervades all time, loss of a self-determining identity. However, the death may be a thankful, and therefore, intrinsically relational death.

The Eucharist expresses the gift of a death thankful for the relationality that pervades the loss of identity in death. Therefore the loss of identity is precious in the eyes of the Lord and the loveableness of this faithful one who has died, becomes a new, relational identity "in the Lord". As singular relationality and loveableness, "yahid", the infinitely loveable one, has lost the temporality of identity, and bypasses this contradiction, by being thankful in the

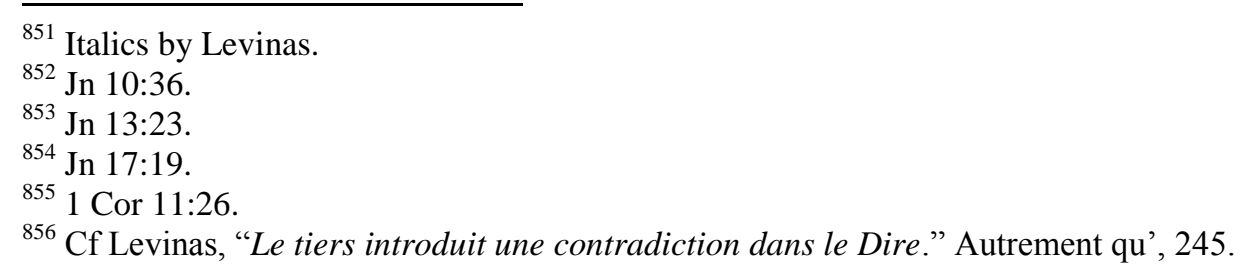


temporality of pure relationship. In short, non-relational identity dies while relational identity is born, and this is celebrated in the Eucharist. At the last supper Jesus seems to overcome his distress about his betrayer, by practicing gratitude and forgiveness.

But whence comes the beginning of relational identity? This may well be the point that was absorbing Thomas' intellectual life in the last year of his life. He was so insightful about the relationality of beginnings and the way in which relational temporality not only relates beginnings to ends, it also relates ends to beginnings. It relates the end and the beginning in such a way that the end (which is infinitely loveable, transforms the beginning rendering it also infinitely loveable). The terminus ad quem, Christ, transforms the terminus a quo, the accidents of bread and wine. The former arrives as infinite ending of relational desire, the latter is changed into the infinite beginning of relational desire. This infinitely disparate diachrony occurs secretly in the apparently synchronic moment of the sacrament itself. Those who accept the merciful gift of infinite diachrony, the gift of an infinite beginning, overcome the contradictions that besiege the shared and conflictual contemporaneity of separated beings. Luke's Gospel demonstrates how the traditioning of the Eucharist and the Holy Spirit are at the heart of the transformation of contradictions.

During his public ministry Jesus asserts that, "I have come to bring fire ( $\pi \tilde{0} \rho$ ) to the earth". Then he adds "I have a baptism to undergo and how distressed I am until it is fulfilled." Finally he declares, "I have not come to bring peace but division $(\delta 1 \alpha \mu \varepsilon \rho 1 \sigma \mu o ́ \varsigma)$ ". ${ }^{858}$ But later in his account of the descent of the Holy Spirit at Pentecost ${ }^{859}$, and also in the earliest account of the last supper ${ }^{860}$, Luke shows that Jesus not only brings fire and division, he also transforms them. Perhaps there is no inter-relation of texts that shows more clearly the difference between nominalization and tradition on the one hand, and verbality and traditioning on the other.

The difference between the text prior to his baptismal death and resurrection and those during and after, is evident in the ways the word group "divide-division" (" $\delta 1 \alpha \mu \varepsilon p i ́ \zeta \omega$ $\delta 1 \alpha \mu \varepsilon \rho ı \mu \varsigma \varsigma ")$ applies through these texts. When Jesus predicts his "baptism" and the "division", he is confronting a nominalising environment with the traditioning of fire. The nominality is reflected in the noun "division"

\footnotetext{
${ }^{857}$ Lk 12:49-50.

${ }^{858}$ Lk 12:51.

${ }^{859}$ Acts 2:1-4.

${ }^{860}$ Lk 22:17-9.

${ }^{861}$ Lk 12:51.
} 
traditionally established environments. "Five in one house will be divided...father against son, son against father, mother against daughter, daughter against mother, mother in law against daughter in law, daughter in law against mother in law." 862 In the language of this thesis, this is a case of a nominalized tradition in conflict. It graphically displays the problem of contradiction between the saying and the said. This reflects a contradiction described by Levinas and already discussed in this section, concerning Levinas and the concurrence of the past (singular) with future (ecclesial) horizons of Eucharistic consecration. It is intrinsic to the understanding of nominalized identities that they belong in the synchronic world of the present. The crises of division in the present, seem to be at the forefront of Jesus mind as he shares about fire and distress without peace, but with division. But, at the time of this prediction, Jesus has still to enter the time of his "baptism", therefore, the diachronic vitality of his death and resurrection have still to enter the world. ${ }^{863}$

It is through the last supper that Jesus enters the radical diachrony of his traditioning. There, in the words over the first cup of the meal he tells his disciples "take this cup and divide it among yourselves for I tell you I shall not drink again from the fruit of the vine until the kingdom of God comes." ${ }^{864}$ Later, at Pentecost, "fire" comes with "division" 865 . The flames of fire divide and settle as tongues on the disciples. These fiery tongues are gifts of communication, Saying without the Said. The relational praxis of traditioning finds in separation and contradiction the call to relationship. This does not mean that identity is eliminated from traditioning. But, in order to sustain the dynamics of traditioning, identity must be based in relationship and defer to relationship above identity. This difficult topic will be taken up in the following and final section of this conclusion to the argument of this thesis. It discusses the Trinity as font of traditioning and revelation of the goodness of relationship and of relational subjectivity.

\section{The Trinity as a source of relational traditioning.}

It has been a surprise to discover, in the writing of this thesis that Thomas Aquinas, the great exponent of infinite agency, has now emerged also as a ground breaking exponent of infinite passivity. The consequent comparisons between him and Levinas that have arisen through

\footnotetext{
${ }^{862}$ Lk 12:52-3.

${ }^{863}$ Lk 12:50.

${ }^{864}$ Luke 22:17-8.

${ }^{865}$ Acts 2:3.
} 
reflecting on passivity now invite a corresponding consideration. Is it possible that Levinas, the first thinker to reflect explicitly on infinite passivity, might also be an exceptional thinker of infinite agency. This is not withstanding the criticisms of ontology that pervade his scholarship. But did he explore agency only in terms of the agency of identities? Throughout this thesis there has been an appeal to a different kind of agency, relational agency. Is this accessible through Levinas, as well as Thomas? Does this open a way to render more explicit, the sense of the Trinity that Thomas was contemplating as he undertook his last works?

Levinas offers profound reflection on the agency of Saying. "L'acte " de dire» aura été , dés le depart, introduit ici comme la suprême passivité de l'exposition à Autrui, qu'est précisément la résponsibilité pour les libres initiatives de l'autre". ${ }^{866}$. Two things are clear from this quote. Firstly, Saying is an act. Secondly it is an act of the supreme passivity of exposure to the other. This same dynamic arises in Thomas' Adoro Te Devote. He began that with "laudo te". But after that initial word of praise he was lost in passivity to the hiding truth of love ${ }^{867}$. Furthermore, in another somewhat astonishing moment in the history of mediaeval theology, he provided a dynamic model of the Trinity, which implied that the Father, the agent lover at the source of the Trinity, was passive to and moved by the loveableness of the Holy Spirit. Therefore both Levinas and Aquinas provided a sense of relationship, according to which Saying says the passivity of loveableness given for the other. "Loveableness" is a term that neither Thomas nor Levinas provide, but it is employed in this thesis to say the positive element that renders relational passivity good, rather than neutral.

To grasp the idea of loveableness a little better it may be helpful to consider Levinas' Introduction of "illeity". "If the relation with illeity were a relation of consciousness - it would designate a theme, probably as the Thou in Buber's I-Thou relationship indicates it." $" 868$

The "probably" is because "Buber never positively exposed the spiritual element where the IThou relationship is produced." ${ }^{869}$ Therefore, Levinas cannot verify his assertion.

On the other hand Levinas was very familiar with Buber and there is certainly a correspondence between Levinas' account of illeity, "the he in the depth of the you"

\footnotetext{
${ }^{866}$ Autrement qu', 81.

${ }^{867}$ Confer above, Chapter 2 Conclusion.

${ }^{868}$ Autrement qu', 28.

${ }^{869}$ Autrement qu', 28.

${ }^{870}$ The Levinas Reader, 178.
} 
Buber's statement, "every singular Thou is a gaze through to him [the eternal Thou]." ${ }^{871}$ This thesis has been written to articulate the thought that, Buber's eternal Thou, Levinas' illeity, and Thomas' the Good, all correspond to what this author means by "loveableness". It is a sense, given by the infinite that renders the one non-indifferent to the other and the infinite. But further to that this thesis seeks how to sustain the sense of loveableness in traditions. It is difficult because if loveableness becomes too strongly identified with a tradition the tradition may treat loveableness as a possession rather than a gift. Therefore this thesis is particularly concerned with articulating the relationality of loveableness.

How may the sense of loveableness be traditioned? In the explorations made throughout the thesis, the concept has been deepened and established, but it remains obscure. Buber's exceptional accounts of the I-Thou relationship may bring greater clarity to the sense of loveableness. This may even come clear without needing lengthy descriptions. In reaching a starting point, one abiding point has already been established - through Thomas and Levinas. - relational agency, or the act of saying gives way in passivity to the relationality of the other The "relational word" 872 "I-Thou" $" 873$ brings considerable clarity to the ways agency and passivity apply to the Trinity. Buber writes in the second paragraph of $I$ and Thou, "when Thou is spoken, the I of the relational word I-Thou is spoken with it." ${ }^{, 874}$ Through this very simple statement Buber articulates the active and passive synthesis in one move. The active synthesis, the word "Thou" is spoken. Then the passive synthesis, the word "I", is bound to the word Thou: a word spoken for the other. Therefore, when the word Thou is spoken to another, the self is rendered de facto, for the other.

This thought may be applied to the Trinity. The Father, saying the relational word "You" also says with that word, "I am Yours." This is the passive sense of the actively spoken word "You". That "the beloved moves the lover" is due precisely to the fact that the word "you" means "I am bound to you. I am moved by you". Hence the questions of freedom, agency and the Trinity cannot be separated from the relational depth of the relational word.

But before continuing with this Buberian account of the Trinity a niggling problem has to be resolved. What kind of model of the Trinity should be used when speaking of the Trinity? An

\footnotetext{
${ }^{871}$ Martin Buber, "Ich und Du" in Das Dialogische Prinzip, 2009, 76.

872 "Wortpaar", "Ich und Du"

873 "You" is you singular, "Du". "Ich und Du", 7. Hence the disambiguating translation "Thou". On the other hand, this disambiguation (thou) fails to catch the sense of intimacy and belonging in the familial "Du". "Ich und Du", 7 .

874 "Ich und Du", 7.
} 
ontological model may be developed through the appreciation of a being's existence as a unity (Holy Spirit) of self-knowing (Son) creativity (Father) in the world. The first person of the Trinity (the Source, who is the Father) may be analogous to the self with its immediately creative sense of possibilities in the world. The second person of the Trinity (the Word who is the Son) may represent the knowledge the self has of itself and its possibilities, and how to develop those possibilities in the world. The third person of the Trinity (the bond of Love who is the Holy Spirit) may be likened to the self-valuing that infuses both the immediate sense of the self's possibilities in the world and the self-care that is reflected in the carrying out of those possibilities. This is the ontological trinity of the self-actualising being: reflected in the triune comportment of the self, of self-knowledge and of self-love. It exhibits the trinitarian sense of life that Thomas developed to such a high degree. "The Good, as known, is loveable to itself," 875 can easily be interpreted as "the good self, [especially the self of God] as known, is loveable to itself". ${ }^{876}$

An alternative to this is the dialogical Trinity based on Buber's I-Thou revolution. It is simpler and more relational than the ontological Trinity and it is steeped in the biblical sense of covenant relationality. It is also based in deference to the other, rather than occupation with the self. But there is one problem. It requires only two parties, not three. This displays in a nutshell the methodological problem of traditioning on the basis of dialogical thought. The task for this part of the thesis is to clarify once again, the Levinasian sense of the third that resolves this problem, and which has been developed in this thesis. This time the solution will be applied through reflection on the source of Christian Traditioning, the Trinity.

The Levinasian reference above to Buber ${ }^{877}$ shows Levinas' great esteem for Buber. He seeks to articulate his own sense of "illeity" by referring to Buber's I-Thou consciousness. On the other hand, Levinas leaves the reader thinking that Buber has not said what needs to be said. Levinas than contributes his thought on illeity and the third. Following Levinas this thesis has set out to articulate a sense of the one for the other in a way that radically includes the third. The contributions of Levinas, Buber and Aquinas are all indispensable to this theory for different reasons. At the base of the theory is the point that the Trinity is based in loveableness. Loveableness is holiness. It is the loveableness of the beloved that sets the lover

\footnotetext{
${ }^{875}$ Compendium Theologiae, 1,45

${ }^{876}$ Compendium Theologiae, 1, 45.

${ }^{877}$ Confer earlier in this section.
} 
apart for the beloved. The argument of the thesis will conclude by showing how loveableness which moves the Trinity also moves traditioning

With regard to how loveableness moves the Trinity the thesis has already explored Aquinas, including his ontological starting point. ${ }^{878}$ This paragraph tries to attend to the issues that lead beyond the ontological starting point, once the ontological starting point is appreciated:

The ontological starting point is that Being is good. ${ }^{879} \mathrm{~A}$ fortiori, each person of the Trinity is Good and therefore self-loving. "The Good is loveable to itself." 880 But, deepening this starting point in a way that involves relationship (as Thomas did), reflection cannot help moving away from preoccupation with the self. The Good person loves more than the self. Therefore the gift of loveableness that the self is to itself, is opened up relationally, a gift of loveableness for the others. Not only that, if the Good person loves relationship than relationality is itself loveable. The gift of loveable goodness that each gives to - and is for the other is the goodness of relationship.

This way of describing the ascent to the goodness of relationship engages with a defining point in Thomas' trinitarian theology. The beloved, who moves the lover is not the Son but the Holy Spirit. ${ }^{881}$ But the Holy Spirit is the Love that is communicated between the Father and the Son ${ }^{882}$ Therefore the loveableness that moves the Father, - the loveableness of the Holy Spirit is the loveableness of relationship, the loveableness of love. But this does not mean that the Son is not also loveable, and does not also move the Father. It means that the Father loves the Son's relationality expressed in the Holy Spirit. To love the relationality of the other is to love the freedom of the other. To live in the gift of one's loveableness is to give oneself to the relational ${ }^{883}$ freedom of the other. The reason the Son gives the Spirit to the Father ${ }^{884}$ is because the Son loves the relationality of the Father.

Each member of the Trinity loves the relationality of the others. On this basis it is possible to define "loveableness". Loveableness is the gift of relationship. Love loves the gift of relationship in the other. Not to love the relationality of the other is to suppress the life of the other, the relationality of the other. To live in the gift of one's loveableness is to affirm the

\footnotetext{
${ }^{878}$ Confer above Chapter 3 part B section 2.

${ }^{879}$ Summa Theological, 1, 5, 1 resp.

${ }^{880}$ Compendium Theologiae, 1, 45.

${ }^{881}$ Compendium Theologiae, 1, 46.

882 Compendium Theologiae, 1, 46.

${ }^{883}$ On this point it is necessary to distinguish between relational freedom and another's self-assertion.

${ }^{884}$ Lk 23:46
} 
relational freedom of the other. Levinas phenomenology explores the relationality of the one for the other. The one is "responsible for the responsibility of the other" 885 . This is an important consideration when the third arrives as the other's other ${ }^{886}$. If the third is the other's other than the other is also one-for-the-other. Therefore, the self is one-for-the-otherone-forthe-other ${ }^{887}$. The self is bound to the other's other therefore there is a bond between the other and the other's other. The self witnesses to that bond and lives for that bond. The bond comes from outside the self, between the other and the third, and comes to the self, (in the understanding of this author), the bond would be illeity, "the he in the depths of the you." That the bond between the one and the other, and the other and the third, all reveal the love of the infinite gives depth and immediacy to the life of traditioning. For the sake of the relationality of the other, the one lives in the bond of love for the other's other. This love, from and for the third, due to the proximity of the other, may seldom be expressed to the third face to face, but it is done nevetheless; through the life of traditioning. Traditioning begins outside the self in the life of care for the other's other. The paradigm of reaching out to the others other, also applies to the Trinity. The Son brings to the Father the Son's other, the Holy Spirit. The Father rejoices in the freedom with which the Son offers and invokes love for the Spirit.

Through the paradigm of love for the other's other (the paradigm of traditioning) the mystery of infinite freedom, which haunts the history of agency and passivity, begins to reveal its ways. Infinite freedom is the freedom of love, freedom through the freedom of the other's other. Therefore, freedom is not simply freedom to enjoy the freedom of the self. Freedom arises out of forgetting the freedom of the self and living for the other's freedom, which also means living for the freedom of the other's other. Freedom is freedom to live for the other's freedom. Therefore, the Freedom of the Father, the agency of the origin of the Trinity, is the freedom to accept the freedom of the end of the Trinity, the freedom of the Holy Spirit. One Freedom confirms the relationality of the other's freedom. But to give oneself to and for the other's relational freedom, (the freedom to love) is to allow oneself to be loved for the sake of the other. As in Bernard's ultimate perfection of love, to love myself for God. Loveableness is loveableness precisely for this reason. It celebrates the freedom of the other's love. It gives free relationship to its other

\footnotetext{
${ }^{885}$ Autrement qu', 186.

${ }^{886}$ Autrement qu', 245

${ }^{887}$ The sequence of hyphens is intentional.

888 "The Levinas Reader", 178.
} 
The beginning and the end of the Trinity, like the beginning and the end of the Eucharist correspond through this relational freedom. The Father says the Freedom of the Spirit and the Spirit says the Freedom of the Father. In so doing the Father receives the Spirit's free witness concerning the Son. That witness, reveals the loveableness of the Son, a loveableness in which the Father rejoices. Freedom is the freedom to be loved.

With this sense of freedom the life of traditioning takes on new horizons. The one is traditioned for the free relationality of the others. Traditioning is outside my freedom in the freedom of the others, between the other and the third. But this freedom must be predilective. It offers relationality to the other before the other can relate and thereby, rather than impose itself on the other, it invites the other to love it. It loves by surrendering to the inspiring gift of the other's love, allowing itself to be traditioned. Even if the love that traditions has yet to arrive, predilection, like "Jesus on the night before he suffered" 889 , allows itself to be handed over by love, even where there is no love. Then pre-dilectively, it brings the gift of love into the world. To tradition is to be traditioned, to allow oneself to be handed over.to the love of the other, even if that love has yet to arrive in the world.

\section{Postlude}

This thesis has been an exploration. As the author I have tried to immerse myself in the dynamics of the tradition it explores, the tradition of the Eucharist. In the course of writing it, the creativity of that tradition has overwhelmed me. And after, so much effort I still feel as if I am at the beginning of the project. So many great authors have said so much and this thesis celebrates so few of their contributions. However, there are some great contributors worthy of special mention, in particular Thomas, Buber, Levinas and Jeremias. My experience is that, for those who have been influenced by them, they have changed the way we view the world. Thanks to them this thesis has been written from the point of view of the related to, rather than the relator, and the sense of relationship has a priority it could not have had previously.

Formed by their thought, this author has come with a new perspective. Hopefully that is to the good. But where there is new subject matter, "traditioning" and "loveableness", it is hard to find guidelines that can establish whether the work is valuable. If there are lacks in the scholarship, and surely there are, that is the author's failing. But the contribution of the many

${ }^{889} 1$ Cor 11:23. 
authors to whom this author has turned, is so creative that it would be unfortunate if their influence was assessed purely through the ways they have been presented in this thesis.

The area of research this thesis enters is new and vast. When there are so many scholars, so much more gifted, to bear fruit through their enquiries, I am perplexed by the fact that I seem to have broached loveableness and traditioning first. On a broader canvas the work may not be so novel. But it still engages with a profoundly neglected matter. My prayer is that my failings in the work will not have turned others aside, but will have helped them see that work always needs to be done to render relationality a topic demanding academic appreciation. For any who follow up on the work here, I am grateful.

According to this thesis, life is about revealing the gift of loveableness and traditioning the gift of being loved. This thesis is written for the infinitely loveable and the infinitely loved. It was written so that loveableness and traditioning may be treated as important elements in religious philosophy, theology, pastoral and liturgical practices, and family life. Therefore, it is written to bind pastoral and academic virtues together, to help people discover the loveableness that they provide. It is also hoped that the effort to articulate a general phenomenology of tradition will be beneficial to scholars outside the traditions in which this thesis has been formed.

Having come to the end and letting go of this work I would like to share briefly my encounter with James K Baxter in 1971. I was 17. We were sharing a conversation with Fr John Healion at the Wellington Catholic Youth Chaplain's Office. Hemi began talking about Buber and said that he considered him the greatest theologian of the twentieth century: "such depth in his works". It seems remarkable that since that day I have sought to articulate Christian faith through Jewish thought. How close have I come to that goal? I don't know. I do know that I have written about the end bringing a new meaning to the beginning, and that contrasts with the Jewish prayer with which I would like to close this work.

"You are the beginning and I am the end.

Who should have mercy on the end if not the beginning"? 


\section{Bibliography}

Aquinas, Thomas. S. Thomae Aquino Opera Omnia. Corpus Thomisticum. Compiled by Enrique Alarcón. Pamplona: Universitas Studiorum Navarrensis, 2000-. http://www.corpusthomisticum.org.

- Summa Theologica. Translated by Fathers of the English Dominican Province. New York: Benzinger Bros., 1947-48. http://dhspriory.org/thomas/summa/.

Augustine. Augustine: Later Works. Edited by John Burnaby. The Library of Christian Classics. Philadelphia: Westminster Press, 1955.

- City of God. Translated by Marcus Dods. From Nicene and Post-Nicene Fathers, First Series, Vol. 2. Edited by Philip Schaff. Buffalo, NY: Christian Literature Publishing Co., 1887. Revised and edited for New Advent by Kevin Knight. http://www.newadvent.org/fathers/1201.htm.

—. Confessions. Translated by R.S. Pine-Coffin. Harmondsworth: Penguin Books, 1984.

- Confessions. In Patrologia Latina, vol. 32. Edited by Jacques Paul Migne. Paris: Garnier, 1877. http://www.augustinus.it/latino/confessioni/index2.htm.

—. De Trinitate. In Patrologia Latina, vol. 42. Edited by Jacques Paul Migne. Paris: Garnies, 1880. http://www.augustinus.it/latino/trinita/index2.htm.

- Tractates on the Gospel of John. Translated by John Gibb. In Nicene and PostNicene Fathers, First Series. Vol. 7. Edited by Philip Schaff. Buffalo, NY: Christian Literature Publishing Co., 1888. Revised and edited for New Advent by Kevin Knight. http://www.newadvent.org/fathers/1701124.htm.

Barth, Karl. Church Dogmatics. Vol. 1, The Doctrine of the Word of God, part 2. Translated by G. T. Thomson and Harold Knight. Edited by G. W. Bromiley and T. F. Torrance. Edinburgh: T \& T Clark, 1956. 
Bernard of Clairvaux. De Diligendo Deo. http://www.pathsoflove.com/bernard/on-lovinggod_la.html.

Bogaert, Pierre-Maurice. "Sub die passionis, une formule liturgique africaine, et le Qui pridie quam pateretur." Benedictine Review 126, no. 1 (2016): 5-15. https://doi.org/10.1484/J.RB.5.110620.

Bradshaw, Paul F. and Maxwell E. Johnson. The Eucharistic Liturgies: Their Evolution and Interpretation. London: Society for Promoting Christian Knowledge, 2012.

Brown, Raymond E. The Gospel According to John. 2 vols. Garden City, NY: Doubleday, 1966.

—. The Epistles of John. Anchor Bible. Vol. 30. New York: Doubleday. 1982.

Buber, Martin. Das Dialogische Prinzip. Munich: Gütersloher Verlagshaus, 2009.

Catherine of Sienna. "Me in You, You in Me." In Teachings of the Christian Mystics. Edited by Andrew Harvey. Boston, MA: Shambhala Publications, 1998.

Catholic Truth Society. The CTS New Sunday Missal. London: Catholic Truth Society, 2011.

Cavanaugh, William. Torture and the Eucharist: Theology, Politics, and the Body of Christ. Oxford: Blackwell Publishing, 1998.

Chrysostom, John. On the Priesthood. Translated by W.R.W. Stephens. From Nicene and Post-Nicene Fathers, First Series, Vol. 9. Edited by Philip Schaff. (Buffalo, NY: Christian Literature Publishing Co., 1889.) Revised and edited for New Advent by Kevin Knight. http://www.newadvent.org/fathers/1922.htm.

Clarke, David L. "Bereft: Derrida's Memory and the Spirit of Friendship." In "Late Derrida," edited by Ian Balfour, special issue, South Atlantic Quarterly 106, no. 2 (Spring 2007): 291-324. http://doi.org/10.1215/00382876-2006-025.

Clement. The Stromata. Translated by William Wilson. From Ante-Nicene Fathers. Vol. 2. Edited by Alexander Roberts, James Donaldson, and A. Cleveland Coxe. Buffalo, 
NY: Christian Literature Publishing Co., 1885. Revised and edited for New Advent by Kevin Knight. http://www.newadvent.org/fathers/0210.htm.

Collins, John J., ed. “Apocalypse: The Morphology of a Genre.” Special issue, Semeia 14 (1979).

Conzelmann, Hans. 1 Corinthians: A Commentary on the First Epistle to the Corinthians. Translated by James W. Leitch. Edited by George W. McRae. Philadelphia: Fortress Press, 2008.

Cooper, Charles, ed. Sing Praise: Words and Music for Liturgical Worship. Wellington, NZ: Price Milburn Music, 1981.

Copleston, Frederick. A History of Philosophy. Vol. 2, Mediaeval Philosophy. Part 2, Albert the Great to Duns Scotus. New York: Doubleday, 1962.

Cyprian. "Epistle LXII: To Caesilius, on the Sacrament of the Cup of the Lord”. Translated by Robert Ernest Wallis. From Ante-Nicene Fathers, vol. 5. Edited by Alexander Roberts and James Donaldson and A. Cleveland Coxe. New York: Christian Literature Publishing Co., 1886. Revised and edited for New Advent by Kevin Knight. http://www.newadvent.org/fathers/050662.htm.

—. "Epistula LXIII: Cyprianus Caecilio Pratris". In Opera Omnia (pars 2): Epistulae. Edited by W. Hartel. 701-717. Vol. 3, part 2 of Corpus Scriptorum Ecclesiasticorum Latinorum, compiled by Academiae Litterarum Caesareae. Vienna: Holder-PichlerTempsky, 1871. http://archive.org/stream/corpusscriptoru16wissgoog.

_. To Donatus. In Ante-Nicene Fathers, vol. 5. Edited by Alexander Roberts and James Donaldson. New York: Charles Scribner's Sons, 1919.

_. "Treatise 3". In Ante-Nicene Fathers, vol. 5. Translated by Robert Ernest Wallis. Edited by Alexander Roberts, James Donaldson, and A. Cleveland Coxe. Buffalo, NY: Christian Literature Publishing Co., 1886. Revised and Edited for New Advent by Kevin Knight. www.newadvent.org/fathers/050703.htm. See also Eucharistic Miracles by Joan Carroll Cruz, xviii. 
Ad Donatum. In Opera Omnia (pars 1): Libelli. Edited by W. Hartel. 3-18. Vol. 3, part 1 of Corpus Scriptorum Ecclesiasticorum Latinorum, compiled by Academiae Litterarum Caesareae. Vienna: Holder-Pichler-Tempsky, 1866. http://archive.org/stream/corpusscriptoru16wissgoog.

Teilhard de Chardin, Pierre. The Divine Milieu: An Essay on the Interior Life. Translated by Bernard Wall. New York: Harper Torchbooks, 2001.

de Jonge, Henk Jan. "The Community Supper according to Paul and the Didache: Their Affinity and Historical Development.” In Paul, John and Apocalyptic Eschatology, edited by Jan Krans, Bert Jan Lietaert Peerbolte, Peter-Ben Smit and Arie Zwiep, 30 47. Boston: Brill, 2013. https://doi.org/10.1163/9789004250369_004.

de la Potterie, Ignace. La vérité dans saint Jean. 2 vols. Rome: Editrice Pontificio Istituto Biblico, 1999.

Derrida, Jacques. Adieu à Emmanuel Levinas. Paris: Galilée, 1997.

—. Aporias: Dying —Awaiting (One Another at) the "Limits of Truth". Translated by Thomas Dutoit. Stanford, CA: Stanford University Press, 1993.

Apories. Paris: Galilée, 1996.

—. De l'esprit: Heidegger et la question. Paris: Galilée, 1987.

_L L'écriture et la difference. Paris: Éditions du Seuil, 1967.

Derrida, Jacques and Didier Eribon. "Heidegger, the Philosopher's Hell.” Translated by Peggy Kamuf. In Points... Interviews 1974-1994, edited by Elisabeth Weber. 181190. Stanford, CA: Stanford University Press, 1997. Interview originally published in La Neuvel Observateur, 6-12 November 1987, 171-172.

The Didache. In The Apostolic Fathers. Vol. 1. Translated by Kirsopp Lake. 303-334.

Farkasfalvy, "The Eucharistic Provenance of New Testament Texts." In Rediscovering the Eucharist: Ecumenical Conversations, ed. by Roch A. Kereszty. 27-51. New York: Paulist Press, 2003. 
Gese Hartmut. Essays on Biblical Theology. Minneapolis: Augsburg Publishing House, 1981.

Gilders, William K. "Ancient Israelite Sacrifice as Symbolic Action: Theoretical Reflections." Svensk Exegetisk Arsbok 78, (2013): 1-22. ATLA Religion Database.

—_. "Sacrifice in Ancient Israel." Essay, in Teaching the Bible. Society of Biblical Literature. https://www.sbl-site.org/assets/media/TBv2_i5.htm.

Heidegger, Martin. Being and Time. Edited by Dennis J. Schmidt. Translated by Joan Stambaugh. Albany: State University of New York Press, 1996.

__. "Nur noch kann ein Gott uns retten.” Der Spiegel 30 (May 1976): 193-219.

—. Sein und Zeit. Tübingen: Max Niemeyer Verlag, 2006.

Herzog, Annabel. "Levinas, memory, and the art of writing." In The philosophical forum, vol. 36, no. 3, pp. 333-343. Oxford, UK and Malden, USA: Blackwell Publishing Ltd., 2005 .

Holy and Great Council of the Orthodox Church. "Message of the Holy and Great Council of the Orthodox Church.” Crete: self-pub. June 2016. https://www.holycouncil.org/Imessage.

_ . "The Importance of Fasting and its Observance Today." Crete: self-pub. June 2016.

International Commission on English in the Liturgy (ICEL), ed. Liturgy of the Hours. Vol. 2, Lenten Season and Easter Season. New York: Catholic Book Publishing Corp., 1976.

Irenaeus. Against Heresis. In Ante-Nicene Fathers, vol. 1. Translated by Alexander Roberts and William Rambaut. Edited by Alexander Roberts, James Donaldson, and A. Cleveland Coxe. Buffalo, NY: Christian Literature Publishing Co., 1885. Revised and Edited for New Advent by Kevin Knight. http://www.newadvent.org/fathers/0103303.htm.

. The Demonstration of the Apostolic Preaching. Translated by Armitage Robinson. London: Aeterna Press, 2015. 
Jeremias, Joachim. The Eucharistic Words of Jesus. Translated by Norman Perrin. New York: Scribner, 1966.

. The Lord's Prayer. Translated by John Reumann. Philadelphia: Fortress Press, 1964.

Justin Martyr. First Apology. Translated by Marcus Dods and George Reith. From Ante-

Nicene Fathers, vol. 1, edited by Alexander Roberts, James Donaldson, and A.

Cleveland Coxe. (Buffalo, NY: Christian Literature Publishing Co., 1885.) Revised

and edited for New Advent by Kevin Knight.

http://www.newadvent.org/fathers/0126.htm.

Kereszty, Roch A., ed. Rediscovering the Eucharist: Ecumenical Conversations. New York: Paulist Press, 2003.

Kierkegaard, Søren. Discourses at the Communion on Fridays. Translated by Sylvia Walsh. Bloomington: Indiana Press, 2011.

Kirmmse, Bruce H., ed. "Illness, Death and Burial." In Encounter with Kierkegaard: A Life as Seen by His Contemporaries, translated by Bruce H. Kirmmse and Virginia R. Laursen, 116-136. Princeton, NJ: Princeton University Press, 1998.

Kwasniewski, Peter A. "A Tale of Two Wonderworkers: St. Nicholas of Myra in the Writings and Life of St. Thomas Aquinas.” Angelicum 82. (2008): 19-43.

Lake, Kirsopp. The Apostolic Fathers. London: W. Heinemann, 1912. Christian Classics Ethereal Library. http://www.ccel.org/ccel/lake/fathers2.

Levinas, Emmanuel. À l’heure des nations. Paris: Éditions de Minuit, 1998.

_. Autrement qu'être ou au-delà de l'essence. Paris: Kluwer Academic, 1990.

—. De Dieu qui vient à l'idée. Paris: Vrin, 1982.

—. De l'évasion. Montpellier: Fata Morgana, 1982.

—. Dieu, la mort et le temps. Paris: Grasset, 1993.

Entre nous. Paris: Grasset, 1991. 
—. Ethique et infini. Paris: Fayard, 1982.

—.Emmanuel Levinas. "God and Philosophy”. The Levinas Reader. ed Sean Hand. Oxford: Basil Blackwell 1989, 166-189.

—. God, Death, and Time. Translated by Bettina Bergo. Stanford: Stanford University Press, 2000.

—. Hors sujet. Montpellier: Fata Morgana, 1982.

_. L'au delà du verset. Paris: Éditions de Minuit, 1982.

—. Noms propres. Montpellier: Fata Morgana, 1976.

—. Nouvelles lectures talmudiques. Paris: Éditions de Minuit, 1996.

_. Of God Who Comes to Mind. Translated by Bettina Bergo. Stanford: Stanford University Press, 1998.

—. Totalité et infini: Essai sur l'extériorité. Paris: Kluwer Academic, 1990.

Lyon, James K. Paul Celan and Martin Heidegger: An Unresolved Conversation, 19511970. Baltimore: John Hopkins University Press, 2009.

Marion, Jean-Luc. Étant Donné: essai d'une phénoménologie de la donation, Presses universitaires de France, Paris, 2005.

_ God without Being: hors-texte Translated by Thomas A. Carlson and with a foreword by David Tracy. Chicago: University of Chicago Press, 2012.

Martin, Francis. "Response to Denis Farkasfalvy." In Rediscovering the Eucharist: Ecumenical Conversations, ed. by Roch A. Kereszty. 52-62. New York: Paulist Press, 2003.

Nodet, Etienne and Taylor, Justin. The Origins of Christianity: An Exploration. Collegeville, MN: Liturgical Press, 1998. 
O'Loughlin, Thomas. The Didache: A Window on the Earliest Christians. London: Society for Promoting Christian Knowledge, 2010.

Panikkar, Raimon. The Rhythm of Being: The Unbroken Trinity, The Gifford Lectures. Maryknoll, NY: Orbis Books, 2010.

Purcell, Michael. Mystery and Method: the Other in Rahner and Levinas. Milwaukee: Marquette University Press, 1998.

Quasten, Johannes. “Tertullian and 'Traditio'.” Traditio 2 (1944): 481-484.

Rea, John. Witness to Wonders: Healings and Miracles Today. East Keilor, Victoria, Australia: Comsoda Communications, 2005.

Reines, Alvin J. “Maimonides’ True Belief Concerning God: A Systematization.” In Maimonides and Philosophy. Edited by S. Pines and Y. Yovel. Dordrecht: Martinus Nijhoff, 1986. 24-35.

Ricoeur, Paul. Soi-même comme un autre. Paris: Éditions du Seuil, 1990.

Rosenzweig, Franz. Stern der Erlösung. Frankfurt am Main: Suhrkamp Verlag, 1988.

Rubin, Miri. Corpus Christi: The Eucharist in Late Medieval Culture. Cambridge: Cambridge University Press, 2004.

Scheler, Max. Der Formalismus in der Ethik und die material Wertethik: Neuer Versuch der Grundlegung eines ethischen Personalismus. With an appendix by Maria Scheler. Edited by Manfred S. Frings. Bonn: Bouvier Verlag, 2000.

- Formalism in Ethics and Non-Formal Ethics of Values: A New Attempt toward the Foundation of an Ethical Personalism. Translated by Manfred S. Frings and Roger L. Funk. Evanston: Northwestern University Press, 1973. Second Vatican Council. Lumen Gentium [Dogmatic Constitution on the Church]. Vatican Website. November 21, 1964.

- Sacrosanctum Concilium [Dogmatic Constitution on the Sacred Liturgy]. Vatican Website. Dec 4, 1963. 
http://www.vatican.va/archive/hist_councils/ii_vatican_council/documents/vat-

ii_const_19641121_lumen-gentium_en.html.

Skeat, Walter W. A Concise Etymological Dictionary of the English Language. New York: Oxford University Press, 1984.

Stern, David E. "Remembering and Redemption.” In Rediscovering the Eucharist: Ecumenical Conversations, ed. by Roch A. Kereszty. 1-15. New York: Paulist Press, 2003.

Strong, James. The New Strong's Exhaustive Concordance of the Bible. Nashville: Thomas Nelson, 1984. https://www.blueletterbible.org.

Tate, Pā Henare. He Puna iti I te Ao Mārama: A Little Spring in the World of Light. Auckland, NZ: Libro International, 2012.

Taylor, Richard. “A Response to David E. Stern.” In Rediscovering the Eucharist: Ecumenical Conversations, ed. by Roch A. Kereszty. 16-26. New York: Paulist Press, 2003.

Teilhard_de Chardin, Pierre. The Divine Milieu: An Essay on the Interior Life. Translated by Bernard Wall. New York: Harper Torchbooks, 2001.

Teresa of Avila. The Interior Castle or the Mansions. Edited by Zimmerman Benedict. Translated by Stanbrook Abbey. London: Thomas Baker, 1921.

Tertullian. De Praescriptione Haereticorum. From Traité de la prescription contre les hérétiques. Edited by R. F. Refoulé. Sources Chrétiennes 46. Paris: Éditions du Cerf, 1957. Transcribed by Roger Pearse, 2001. http://www.tertullian.org/latin/de_praescriptione_haereticorum.htm.

Tesoriero, Ron and Lee Han. Unseen New Evidence: The Origin of Life Under the Microscope. Kincumber, NSW: printed by Ron Tesoriero, 2013.

Thomaskutty, Johnson. Saint Thomas the Apostle: New Testament, Apocrypha, and Historical Traditions. Vol. 25. London: Bloomsbury Publishing, 2018. 206-7. 
Ticciati, Susannah. "The Human Being as Sign in Augustine's De doctrina Christiana." Neue Zeitschrift für systematische Theologie und Religionsphilosophie 55, no. 1 (January 2013): 20-32.

Van der Pool, Charles. The Lexical Concordance of the Apostoloic Bible. Newport: Apostolic Press, 2003.

van Roo, William A. The Christian Sacrament. Rome: Pontificia Università Gregoriana, 1992.

Vanier, Jean. Drawn into the Mystery of Jesus though the Gospel of John. St Paul's University: Novalis, 2004.

Voegelin, Eric. Order and History. Vol. 2, The World of Polis. Columbia, MO: University of Missouri Press, 2000.

Von Hügel, Friedrich. The Mystical Element of Religion: As Studied in Saint Catherine of Genoa and her Friends. With and introduction by Michael Downey. New York: Crossroad Publishing Company, 1999.

von Wahlde, Urban C. The Gospel and Letters of John. 3 vols. Grand Rapids, MI: Eerdmans, 2010.

Wallenfang, Donald. Dialectical Anatomy of the Eucharist: an Étude in Phenomenology. Jean-Luc Marion, Introduction. Wipf and Stock Publishers, Eugene OR, 2017.

Wallis, Robert Ernest. Ante-Nicene Fathers. Vol. 5. Edited by Alexander Roberts, James Donaldson, and A. Cleveland Cox. Buffalo, NY: Christian Literature Publishing Co., 1886. Excerpt: Epistles of Cyprian of Carthage. Revised and edited for New Advent by Kevin Knight. http://www.newadvent.org/fathers/0506.htm.

Weber, Elisabeth, ed. Points... Interviews 1974-1994. Stanford, CA: Stanford University Press, 1997.

Zirkel, Patricia McCormick. "The Ninth-Century Eucharistic Controversy: A Context for the Beginnings of Eucharistic Doctrine in the West.” Worship 68, no. 1 (January 1994): 2-23. ATLA Religion Database. 